VENICIO FERREIRA DE ALMEIDA

\title{
METODOLOGIA PARA AVALIAR O IMPACTO DE TÉCNICAS DE REPOTENCIAÇÃO NO DESEMPENHO DE LINHAS DE TRANSMISSÃO EM REGIME PERMANENTE
}





\title{
METODOLOGIA PARA AVALIAR O IMPACTO DE TÉCNICAS DE REPOTENCIAÇÃO NO DESEMPENHO DE LINHAS DE TRANSMISSÃO EM REGIME PERMANENTE
}

\begin{abstract}
Dissertação apresentada à Escola de Engenharia de São Carlos, da Universidade de São Paulo, como parte dos requisitos para a obtenção do Título de Mestre em Ciências, pelo Programa de Engenharia Elétrica.
\end{abstract}

Área de Concentração: Sistemas Elétricos de Potência Orientador: Prof. Dr. José Carlos de Melo Vieira Júnior

São Carlos

2013

Trata-se da versão corrigida da dissertação. A versão original se encontra disponível na EESC/USP que aloja o Programa de Pós-Graduação de Engenharia Elétrica. 
AUTORIZO A REPRODUÇÄO TOTAL OU PARCIAL DESTE TRABALHO, POR QUALQUER MEIO ĆONVENCIONAL OU ELETRÔNICO, PARA FINS DE ESTUDO E PESQUISA, DESDE QUE CITADA A FONTE.

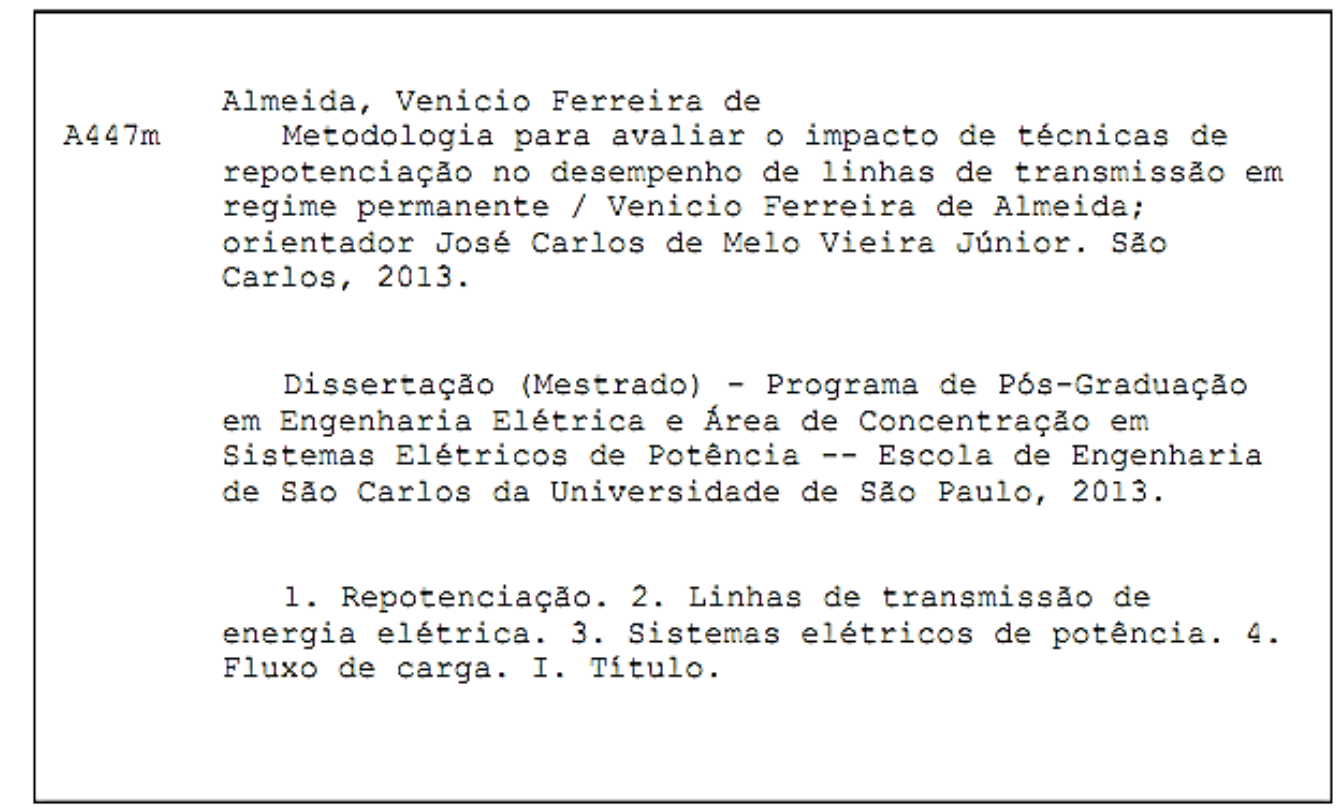




\section{FOLHA DE JULGAMENTO}

\section{Candidato: Engenheiro VENICIO FERREIRA DE ALMEIDA}

Título da dissertação: "Metodologia para avaliar o impacto de técnicas de repotenciação no desempenho de linhas de transmissão em regime permanente".

Data da defesa: 29/10/2013

\section{Comissão Julgadora:}

Resultado:

Prof. Dr. José Carlos de Melo Vieira Junior (Orientador)

APROVADO

(Escola de Engenharia de São Carlos/EESC)

Prof. Dr. Mário Oleskovicz

APROVADO

(Escola de Engenharia de São Carlos/EESC)

Prof. Dr. José Alfredo Covolan Ulson

APROVADR

(Universidade Estadual Paulista "Júlio de Mesquita Filho"/UNESP- Bauru)

Coordenador do Programa de Pós-Graduação em Engenharia Elétrica e Presidente da Comissão de Pós-Graduação:

Prof. Titular Denis Vinicius Coury 



\section{Dedicatória}

Aos meus

pais, David e Vitória, e a todos aqueles que acreditaram na realização desse trabalho. 


\section{Agradecimentos}

À Deus, primeiramente, por me proporcionar saúde e persistência nos objetivos.

À minha família, pela confiança e incentivo perante as dificuldades.

Ao Prof. Dr José Carlos de Melo Vieira Júnior, pela confiança, paciência e ética em que me auxiliou nesta trajetória.

Aos professores Denis Vinicius Coury e Mário Oleskovicz, pelo respeito e disponibilidade que me proporcionaram, e pela oportunidade em trabalhar com profissionais de tamanho conceito.

Aos amigos que aqui formei e pude dividir grandes alegrias e desafios, em especial: Etienne, Hermes, Lucas, Sérgio, Patrick, Gustavo e Helson.

A todos os funcionários da Escola de Engenharia de São Carlos, pelo respeito e dedicação prestada em todos os assuntos pertinentes a minha formação nesta Universidade. 


\section{Sumário}

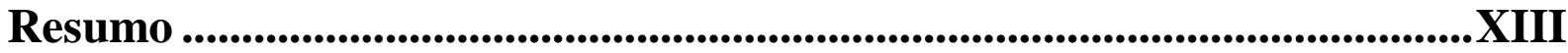

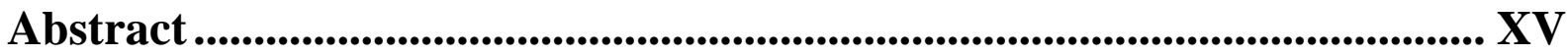

Lista de Figuras .......................................................................................... XII

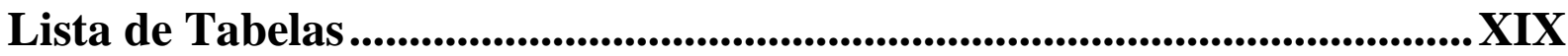

Lista de Símbolos e Abreviações.....................................................................XXI

Capítulo 1 Introdução........................................................................................... 23

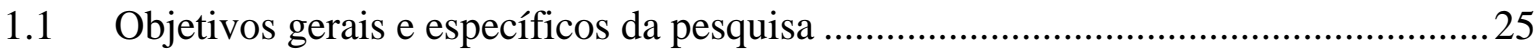

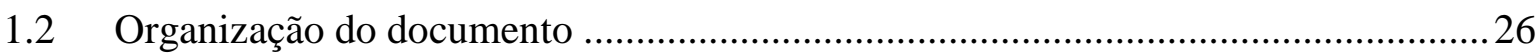

\section{Capítulo 2 Repotenciação de Linhas de Transmissão de Energia Elétrica 29}

2.1 Experiências já executadas com Repotenciação de Linhas de Transmissão .............29

2.2 Conceitos para Repotenciação de Linhas de Transmissão ....................................... 38

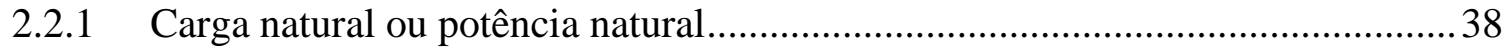

2.2.2 Máxima transferência de potência de uma linha de transmissão ......................... 40

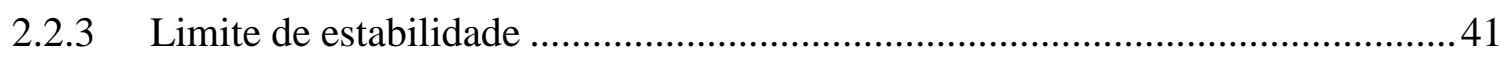

2.3 Técnicas de repotenciação ........................................................................... 42

2.3.1 Alteração do Limite Térmico da Linha de Transmissão .................................... 43

2.3.2 Recondutoramento da Linha de Transmissão ................................................... 44

2.3.3 Lançamento de mais Subcondutores por Fase na Linha de Transmissão ........... 44

2.3.4 Modificação da Tensão Operativa da Linha de Transmissão .............................. 45

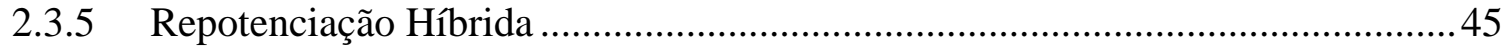

Capítulo 3 Metodologia de Análise...................................................................... 47

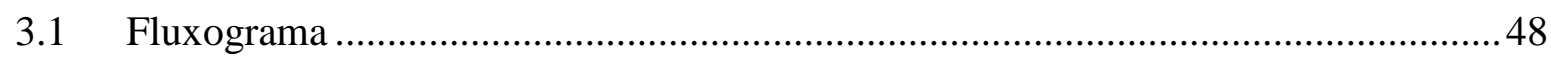

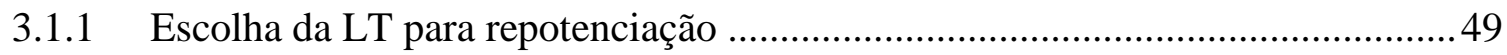

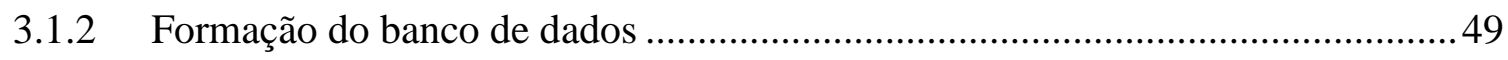

3.1.3 Seleção das técnicas de repotenciação aplicáveis ............................................50

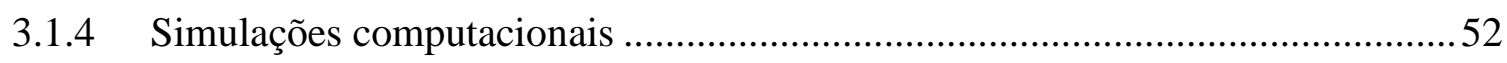


3.1.5 Análise dos fatores de desempenho e índices de mérito agregado em regime

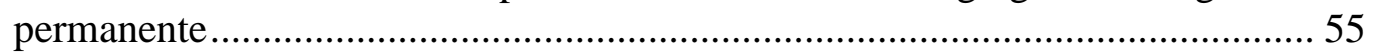

3.1.6 Identificação da melhor técnica de repotenciação ...............................................56

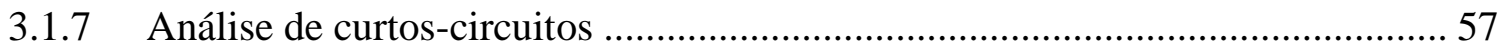

3.2 Fatores de Desempenho na Repotenciação da LT em Regime Permanente ............. 58

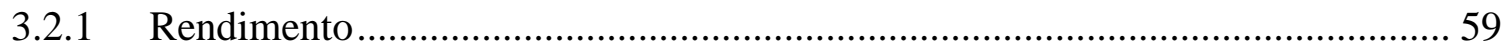

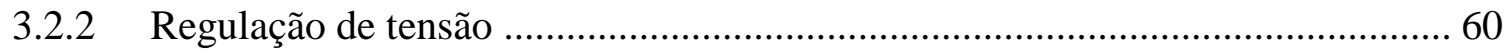

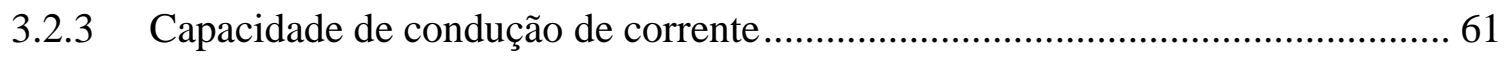

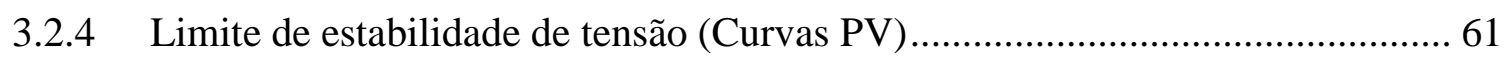

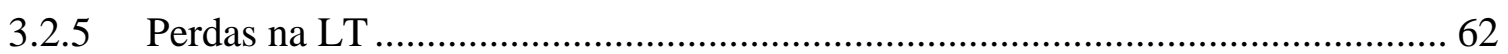

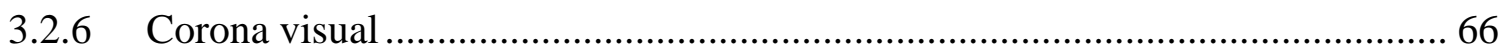

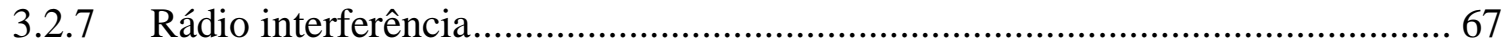

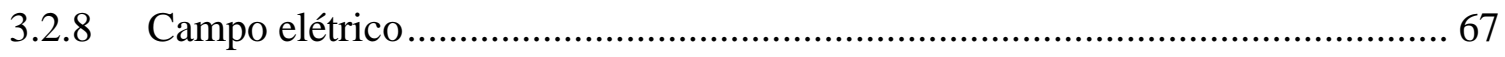

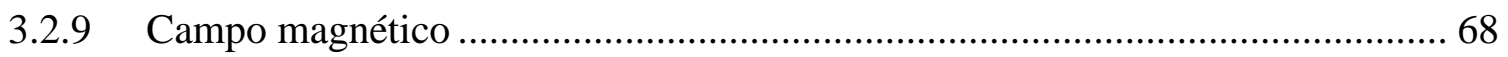

3.3 Índices de Mérito Agregado Avaliados na Repotenciação em Regime Permanente 69

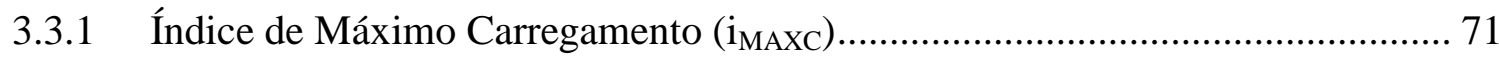

3.3.2 Índice de Máximo Carregamento restrito por tensão (i $\mathrm{i}_{\mathrm{MAXC} \_\mathrm{V}}$ ) .......................... 72

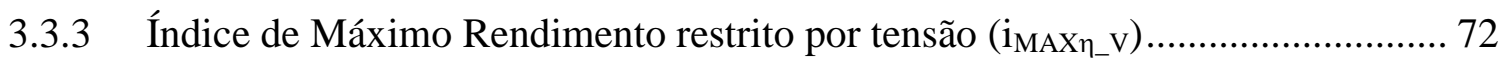

3.3.4 Índice de Máxima Regulação restrito por tensão (i $\mathrm{i}_{\text {MAXR_V }}$ ) ............................... 73

Capítulo 4 Aplicação da Metodologia................................................................ 75

4.1 Escolha da Linha para Repotenciação e Composição do Banco de Dados............... 75

4.2 Seleção da Técnica de Repotenciação.................................................................. 77

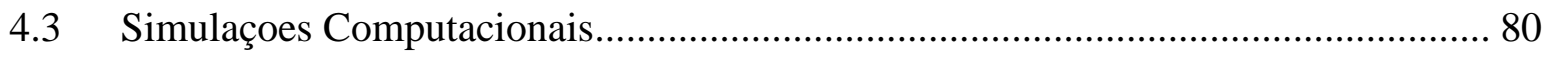

4.4 Resultados das Análises dos Fatores de Desempenho ........................................... 84

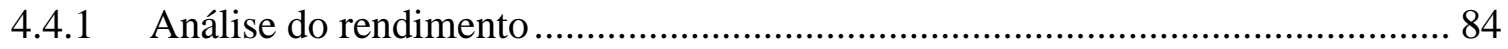

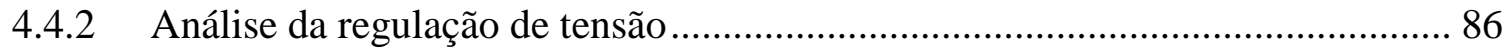

4.4.3 Análise da capacidade de condução de corrente.................................................. 88

4.4.4 Análise do limite de estabilidade de tensão (Curvas PV) ................................. 89

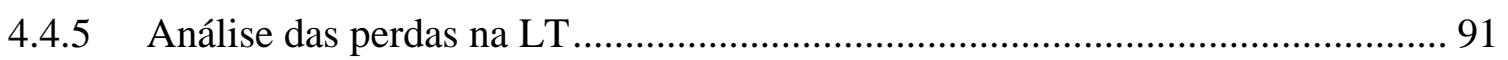

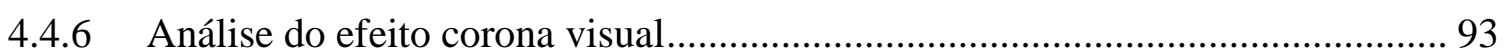

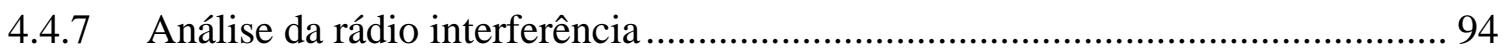

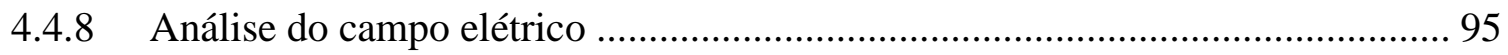

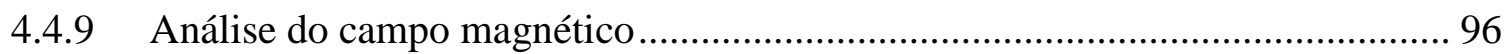

4.5 Resultados das Análises dos Índices de Mérito Agregado..................................... 97 
4.6 Identificação de Mudanças na LT .98

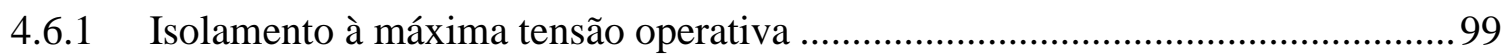

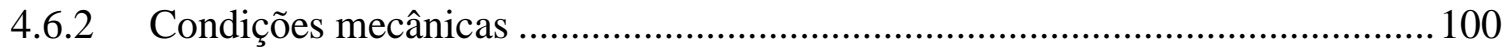

4.7 Identificação da Melhor Técnica de Repotenciação ............................................... 102

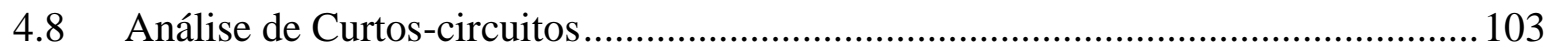

4.8.1 Análise da variação das grandezas de corrente e tensão .................................. 104

4.8.2 Análise de suportabilidade dos disjuntores .................................................... 112

4.9 Considerações Finais do Capítulo............................................................................. 114

Capítulo 5 Conclusões..................................................................................... 116

Referências Bibliográficas ..................................................................................... 120

ANEXO A Dados da LT Furnas - Poços de Caldas ........................................... 125

ANEXO B Procedimentos para Cálculo dos Fatores de Desempenho e Índices de Mérito Agregado ...................................................................................... 131

B.1 Demonstração de Cálculo dos Fatores de Desempenho .......................................... 135

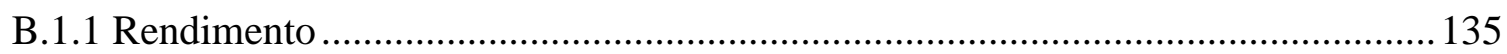

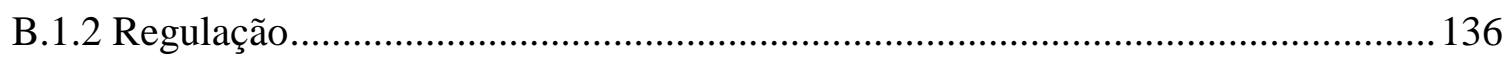

B.1.3 Capacidade de condução de corrente ................................................................... 137

B.1.4 Limite de estabilidade de tensão (Curvas PV) ................................................... 137

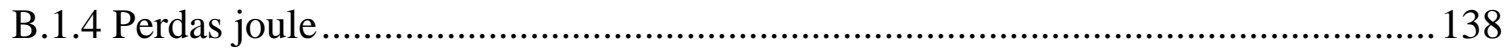

B.1.5 Perdas por efeito corona, corona visual e rádio interferência ............................... 138

B.1.6 Campo elétrico e Campo magnético ................................................................... 142

B.2 Demonstração de Cálculo dos Índices de Mérito Agregado..................................... 147

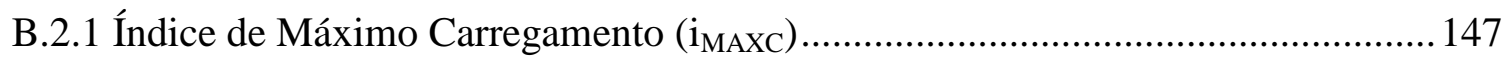

B.2.2 Índice de Máximo Carregamento restrito por tensão (i $\mathrm{i}_{\text {MAXC_V }}$ )............................. 147

B.2.3 Índice de Máximo Rendimento restrito por tensão (i $\left.\mathrm{i}_{\mathrm{MAX} \eta_{-} \mathrm{V}}\right)$................................ 148

B.2.4 Índice de Máxima Regulação restrito por tensão (i $\mathrm{i}_{\text {MAXR_V }}$ )................................. 149

ANEXO C Requisitos Mínimos para Linhas de Transmissão....................... 151

C.1 Cálculo do Isolamento à Tensão Máxima Operativa ................................................ 153

C.2 Cálculo das Distâncias de Segurança.................................................................... 154 
C.2.1. Cálculos das distâncias disruptivas da cadeia de isoladores

ANEXO D Resultados das Análises de Curto-Circuito ............................... 163

ANEXO E Publicações............................................................................................ 171 


\section{Resumo}

\section{ALMEIDA, V. F., Metodologia para avaliar o impacto de técnicas de repotenciação no} desempenho de linhas de transmissão em regime permanente. São Carlos, 2013, p. 173. Dissertação de Mestrado - Escola de Engenharia de São Carlos, Universidade de São Paulo.

O presente trabalho tem como objetivo propor uma metodologia para avaliar o impacto das diversas técnicas de repotenciação no desempenho de linhas de transmissão em regime permanente, visto que na atual literatura não existe uma análise abrangente que possa ser aplicada em qualquer linha de transmissão carente de repotenciação. A metodologia busca fornecer subsídios para escolha da técnica mais vantajosa para repotenciar uma linha, utilizando de forma extensiva, os fatores de desempenho, e de forma sintetizada, os índices de mérito agregado, que, avaliados individualmente e/ou em conjunto, propiciam informações qualificadas para as conclusões técnicas. Destaca-se que a proposição dos fatores de desempenho e dos índices de mérito são as principais contribuições deste trabalho. Para complementar a metodologia, uma análise de curtos-circuitos foi proposta. Os resultados da utilização da metodologia foram positivos, possibilitando verificar os ganhos de potência na transmissão de energia. Vale destacar a eficiência dos índices de mérito agregado, que identificaram a melhor técnica de repotenciação de forma sintetizada, resguardando a qualidade e enquadramento dos resultados nas normas regulamentadoras.

Palavras-chave: Repotenciação, Linhas de transmissão de energia elétrica, Sistemas elétricos de potência, Fluxo de carga. 


\section{Abstract}

ALMEIDA, V. F., Method for assessing the impact of transmission lines upgrade techniques on their steady-state performance. São Carlos, 2013, p. 173. Master Dissertation - São Carlos School of Engineering, University of São Paulo.

This work aims at proposing a methodology to assessing the impact of power upgrade techniques on the steady-state performance of transmission lines, since there is not anything similar to this in the technical literature. The proposed methodology aims at providing technical information to subside the choice of the best power line upgrade technique, by the extensive application of the performance factors and of the aggregate merit indices. It must be pointed out that the proposition of the performance factors and of the aggregate merit indices are the main contributions of this work. Additionally, a short circuit analysis was also proposed to assess the power upgrade techniques. The results after the method application were satisfactory and allowed verifying the surplus of power related to each upgrade technique. The contribution of the aggregate merit indices was very important to identifying the most favorable upgrade technique in a simple way, so that all statutory technical limits were not violated.

Palavras-chave: power line upgrade, transmission lines, electrical power systems, load flow. 


\section{Lista de Figuras}

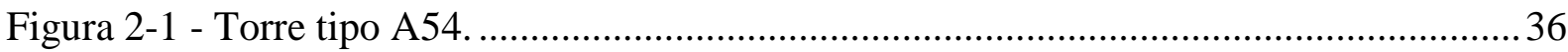

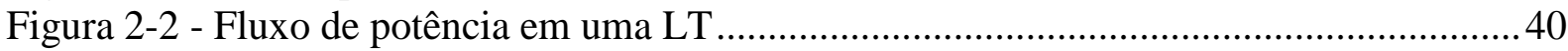

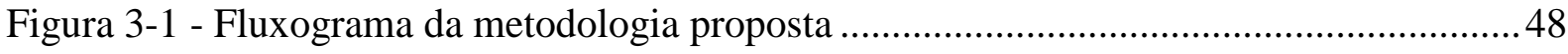

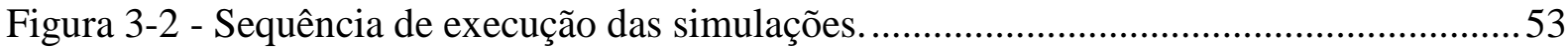

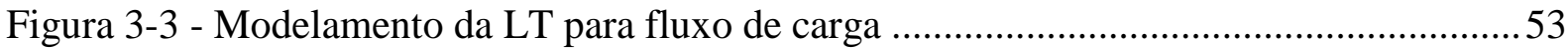

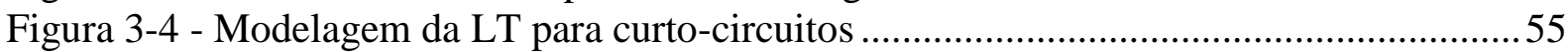

Figura 3-5 - Coeficiente de estado da superfície dos condutores "m". (Fonte: Fuchs, (1977))65

Figura 3-6 - Índice Pn (perdas reduzidas sob chuva) (Fonte: Fuchs, (1977)) ...........................66

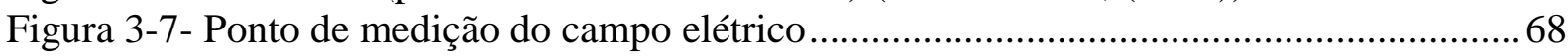

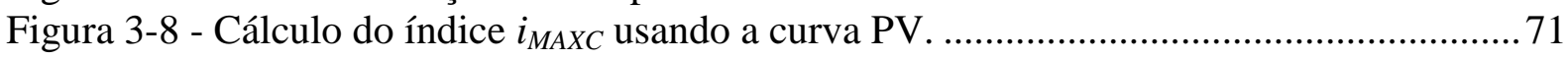

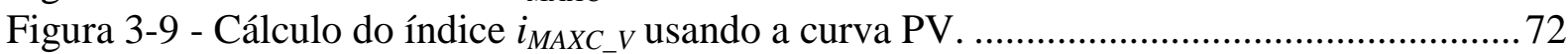

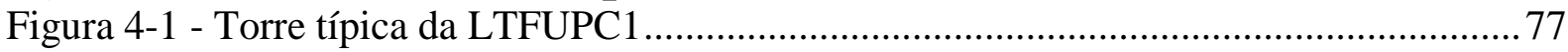

Figura 4-2 - Configurações dos condutores empregados nas técnicas de repotenciação......... 79

Figura 4-3 - Sistema elétrico analisado representando a LT .................................................. 81

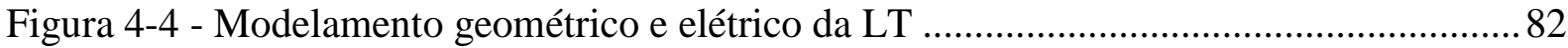

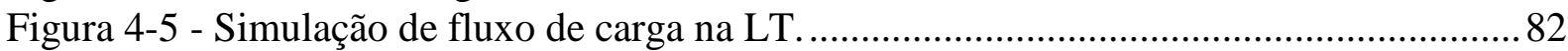

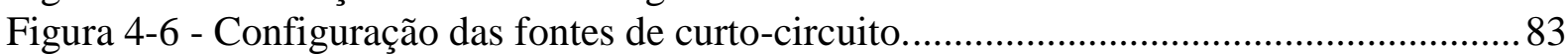

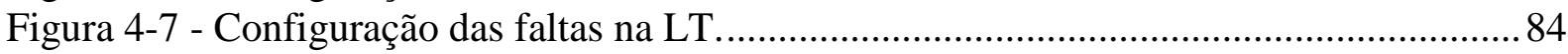

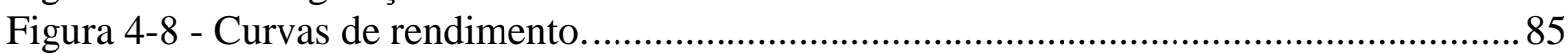

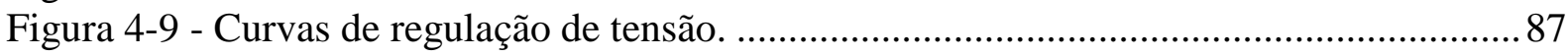

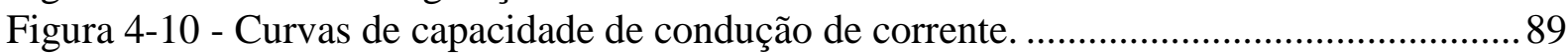

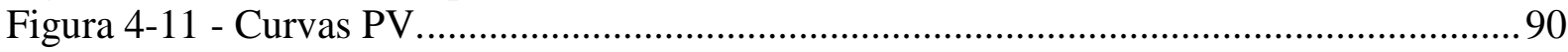

Figura 4-12 - Curvas PV - limite inferior de tensão de regime permanente. ...........................91

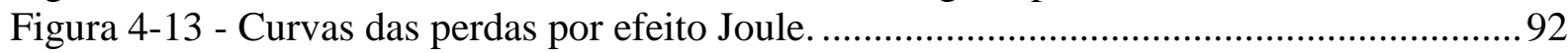

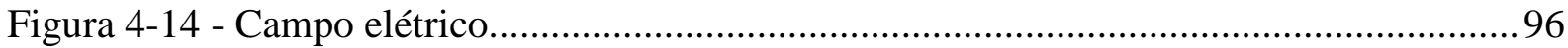

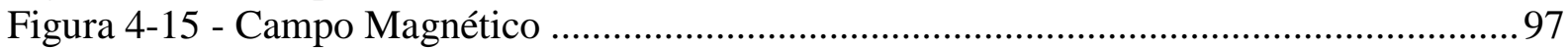

Figura 4-16 - Correntes sob falta trifásica franca no barramento de Furnas .......................... 105

Figura 4-17 - Correntes sob falta monofásica em Furnas...................................................... 107

Figura 4-18 - Tensões de fase sob falta monofásica em Furnas........................................... 108

Figura 4-19 - Tensões de fase sob falta monofásica em Furnas, com resistência de falta. .... 108

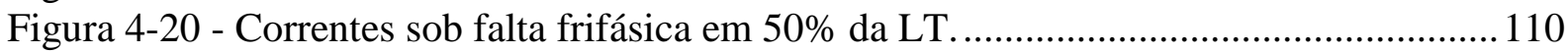

Figura 4-21 - Correntes sob falta monofásica em 50\% da LT............................................ 111

Figura 4-22 - Tensões de fase sob falta monofásica em 50\% da LT...................................111

Figura 4-23 - Tensões de fase sob falta monofásica em 50\% da LT, com resistência de falta na

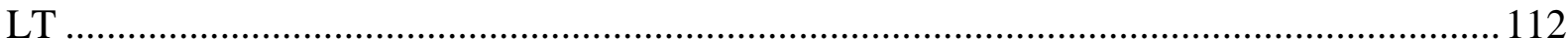

Figura B-1 - Parâmetros de cálculo do campo elétrico superficial do condutor ....................139

Figura B-2 - Dados da fase dos cabos da LT ................................................................... 140

Figura B-3 - Dados geométricos dos cabos da LT .......................................................... 140

Figura B-4 - Resultado para Campo elétrico superficial dos condutores ............................. 141

Figura B-5 - Dados do ponto de referência para medição .................................................. 142

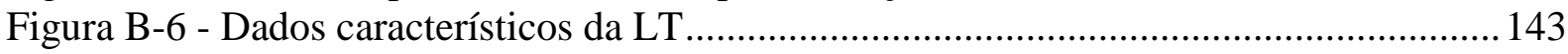

Figura B-7 - Dados característicos da fase da LT ........................................................ 143

Figura B-8 - Dados geométricos dos cabos condutores de cada fase da LT ......................... 144

Figura B-9 - Planilha de resultados campo elétrico.......................................................... 145 


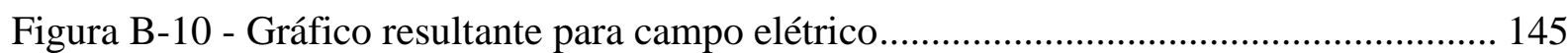

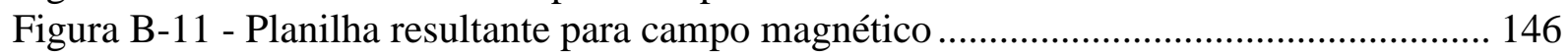

Figura B-12 - Gráfico resultante para campo magnético ................................................. 146

Figura C- 1- Dimensões mínimas da janela de estrutura com cadeia em I........................... 158

Figura C- 2- Cálculo das distâncias disruptivas............................................................... 161 


\section{Lista de Tabelas}

Tabela 2-1 - Valores típicos de impedância de surto e potência natural para linhas aéreas

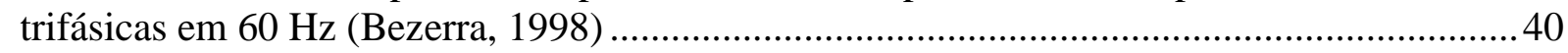

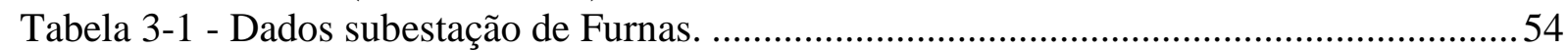

Tabela 3-2 - Dados subestação de Poços de Caldas ...................................................................55

Tabela 4-1 - Rendimento para transmissão de 660 MW com fator de potência 0,95 indutivo,

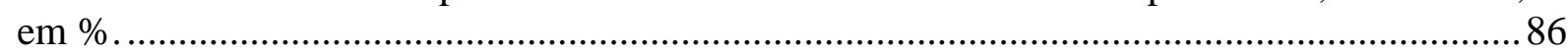

Tabela 4-2 - Regulação de tensão para transmissão de 660 MW, fator de potência 0,95

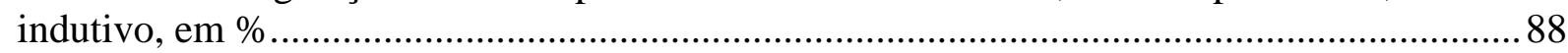

Tabela 4-3 - Tensão no receptor para 660 MW para transmissão de 660 MW com fator de

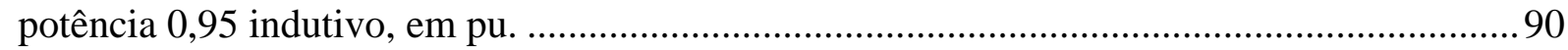

Tabela 4-4 - Perdas por efeito Joule na LT para transmissão de 660 MW com fator de

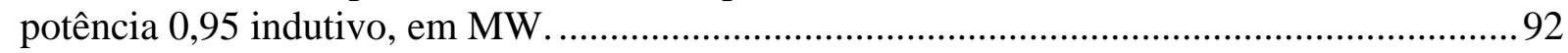

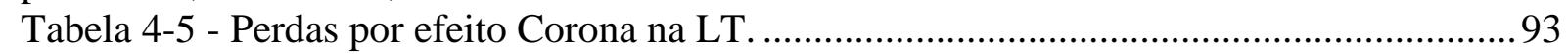

Tabela 4-6 - Determinação do efeito Corona visual na LT. .................................................... 94

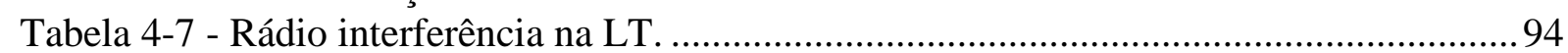

Tabela 4-8 - Índices de Mérito Agregado............................................................................. 98

Tabela 4-9 - Tabela das distâncias mínimas de segurança para máxima tensão operativa ......99

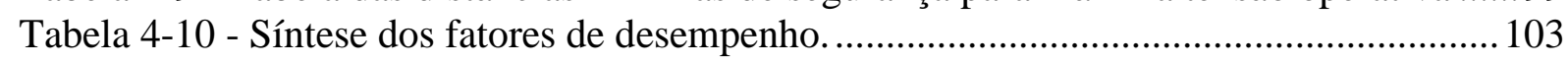

Tabela 4-11 - Suportabilidade do disjuntor do barramento de Furnas ...................................113

Tabela 4-12 - Suportabilidade do disjuntor do barramento de Poços de Caldas ..................... 114

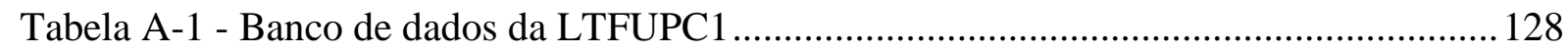

Tabela B-1 - Grandezas coletadas no fluxo de carga em regime permanente, pela configuração

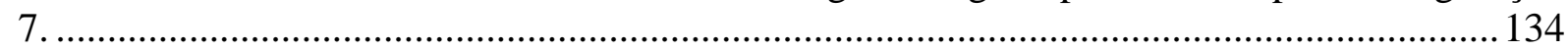

Tabela B-2 - Rendimento e regulação para configuração 7. .............................................. 135

Tabela C-1- Tabela de valores dos espaçamentos verticais em diferentes condições, de acordo com os níveis de tensão de transmissão (Norma NBR-5422)............................................. 155

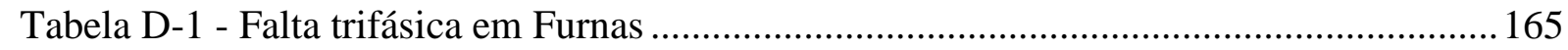

Tabela D-2 - Falta trifásica em Furnas com resistência de falta .......................................... 165

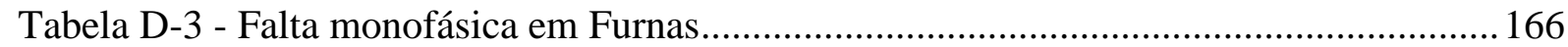

Tabela D-4 - Falta monofásica em Furnas com resistência de falta ...................................... 166

Tabela D-5 - Falta trifásica em Poços de Caldas.................................................................... 166

Tabela D-6 - Falta trifásica em Poços de Caldas com resistência de falta .............................. 167

Tabela D-7 - Falta monofásica em Poços de Caldas ............................................................. 167

Tabela D-8 - Falta monofásica em Poços de Caldas com resistência de falta......................... 167

Tabela D-9 - Falta Trifásica em 50\% da LT....................................................................... 168

Tabela D-10 - Falta trifásica em 50 \% da LT, com resistência de falta ............................... 168

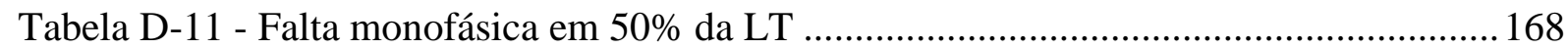

Tabela D-12 - Falta monofásica em 50\% da LT, com resistência de falta............................ 169 
XX 


\title{
Lista de Símbolos e Abreviações
}

\author{
AAAC - All Aluminum Alloy Conductor \\ ACSR - Aluminum Conductor Steel Reiforced \\ ANEEL - Agência Nacional de Energia Elétrica
}

CAA - Cabos de alma de aço

CAL - Cabos de liga de alumínio

CE - Campo Elétrico

$\mathrm{CM}$ - Campo Magnético

$\mathrm{dB}$ - Decibéis

ECRV - Gradiente crítico visual do condutor

EDS - Every Day Stress

ICC - Corrente de curto-circuito pelo disjuntor

ICCS - Capacidade de interrupção de corrente simétrica do disjuntor

IMA - Índices de Mérito Agregado

$\mathrm{i}_{\text {MAXC }}$ - Índice de máximo carregamento

$\mathrm{i}_{\text {MAXC_V }}$ - Índice de máximo carregamento restrito por tensão

$\mathrm{i}_{\mathrm{MAX \eta} \eta_{-} \mathrm{V}}$ - Índice de máximo rendimento restrito por tensão

$\mathrm{i}_{\text {MAXR_V }}$ - Índice de máxima regulação restrito por tensão

LPNE - Linhas de Potência Natural Elevada

LPNE/FEX - Linhas de Potência Natural Elevada com Feixe Expandido

LT - Linhas de transmissão

$\mathrm{m}$ - Coeficiente de estado de superfície do condutor

$\mathrm{mG}$ - miligauss

OPGW - Optical Ground Wire

PLS CADD - Power Line Systems - Computer Aided Design and Drafting

$P$ max - Potência máxima transmitida pela LT

$P_{M A X V}$ - Potência máxima restrita por tensão

PV - Potência em relação à tensão

$P_{0}-$ Potência natural da LT

$R_{M A X_{-} V}-$ Regulação máxima restrita por tensão

SCC - Potência de curto-circuito 
XXII

SIL - Surge Impedance Loading

$V_{r}$ - Tensão no receptor

$Z_{C}$ - Impedância característica da LT

$Z_{0}$ - Impedância natural da LT

$\eta_{M A X_{-} V}-$ Rendimento máximo restrito por tensão

$\delta 1$ - Ângulo de fase da barra 1

$\delta 2$ - Ângulo de fase da barra 2

$1 \mathrm{~F}$ - Curto-circuito monofásico

$3 \mathrm{~F}$ - Curto-circuito trifásico 


\section{Capítulo 1}

\section{Introdução}

A crescente demanda de energia verificada nos sistemas elétricos em todo o mundo exige que os órgãos responsáveis pelo setor elétrico adotem medidas para garantir o atendimento da carga. Se por um lado o aumento da capacidade de geração de energia elétrica é uma medida essencial para atingir esse objetivo, o transporte da energia desde os centros geradores até os consumidores também figura como uma questão de suma importância neste contexto. Em alguns casos, devido ao crescimento da carga, têm-se linhas de transmissão (LTs) operando no limite de sua capacidade, mesmo com a instalação de equipamentos de compensação, como, por exemplo, capacitores em série com as linhas. Logo, deve-se garantir uma estrutura adequada do sistema de transmissão, de forma que toda a energia elétrica produzida seja transportada com boa qualidade, confiabilidade, visando economia e minimização de impactos ambientais. Para tanto, duas soluções apresentadas a seguir, são possíveis, confome Oliveira (2000).

- Expansão do sistema de transmissão de energia elétrica pela construção de novas linhas: frequentemente esse processo tem como barreira as dificuldades de obter licenciamento ambiental devido à constituição de novas faixas de servidão;

- Recapacitação ou repotenciação de linhas de transmissão: consiste em aumentar a capacidade de transferência de potência das linhas de transmissão, efetuando modificações naquelas já existentes. Esta solução apresenta a vantagem de não necessitar de uma nova licença ambiental, uma vez que a 
linha repotenciada ocupará a mesma faixa de servidão. Além disso, os custos associados tendem a serem inferiores aos referidos na primeira solução.

Referindo-se à repotenciação das linhas de transmissão, a literatura apresenta diversas técnicas para maximizar a capacidade de transmissão das linhas. Entre elas encontram-se a instalação de capacitores em série com a linha, aumento da tensão operativa, substituição dos condutores originais por condutores termorresistentes, lançamento de condutores adicionais no feixe de condutores ou a combinação de duas ou mais técnicas, conforme cita Oliveira (2000). A seleção da técnica mais adequada depende fortemente de aspectos técnicos e econômicos, os quais devem ser avaliados caso a caso para que os reais benefícios da repotenciação possam ser discriminados. Neste aspecto, trabalhos como Oliveira (2000) e Silva e Baumann (1997) discutem algumas características técnicas da linha de transmissão que devem ser consideradas quando se aplicam determinados métodos de repotenciação. No entanto, as análises efetuadas por esses trabalhos não podem ser generalizadas, pois não consideram fatores importantes para avaliar o desempenho de uma linha de transmissão, tais como perdas por efeito Joule e efeito Corona, margem estabilidade de tensão e máximo carregamento para operar dentro do nível de tensão permitido, entre outras.

Já em trabalhos como de Stephan e Costa (2007), onde são apresentadas várias frentes de recapacitação de LT na empresa Eletrosul, nota-se a carência de uma metodologia e organização dos procedimentos para recapacitação de LTs. As linhas de transmissão recapacitadas ou repotenciadas estão construídas em sistemas elétricos distintos, com características construtivas diversas, situadas em condições ambientais também diferentes, ocasionando ineficiência na execução das atividades desde o estudo até a execução da recapacitação. Algumas questões não foram previamente salientadas para execução das obras, como: adequação aos fatores limitantes das normas regulamentadoras de transmissão de 
energia, descarte imediato de técnicas de recapacitação, formação de banco de dados e estudos técnicos que poderiam ser descartados, evitando desperdício de tempo e recursos financeiros. Os próprios autores concluem em seus relatos que existe a necessidade da criação de um documento ordenado para recapacitação de linhas de transmissão, devido à quantidade elevada de procedimentos e critérios adotados na execução desses projetos.

Em Cavassim e Fernandes (2012) os autores fazem uma abordagem multicritérios para recapacitação de linhas de transmissão, ponderando critérios como maximização de altura-solo, maximização da ampacidade, maximização da sobrevida da linha em função da ampacidade, perdas e acréscimos de esforços na estrutura. De fato a abordagem descreve as condições mecânicas mais eficientes em que a LT deve ser recapacitada, para atingir os objetivos de maximização dos critérios analisados, porém, esta abordagem carece de outros fatores importantes na transmissão de energia elétrica, tais como: estudos de campo elétrico, campo magnético e índices que permitam comparar e eleger a melhor técnica de recapacitação para a LT escolhida. Assim, uma metodologia que pudesse aglutinar essas considerações contribuiria bastante para maximizar a transmissão de energia elétrica na LT, considerando vários fatores de desempenho e adequando-se a normas de transmissão de energia elétrica.

\subsection{OBJETIVOS GERAIS E ESPECÍFICOS DA PESQUISA}

Com o objetivo de suprir as carências apresentadas no tópico anterior, este trabalho propõe uma metodologia para comparar o desempenho de linhas de transmissão de energia elétrica quando submetidas a diferentes técnicas de repotenciação. Sempre visando uma análise técnica, serão avaliadas tanto características de regime permanente quanto algumas características relacionadas a curtos-circuitos. A metodologia se baseia na proposição dos seguintes mecanismos: 
- Fatores de desempenho: visam indicar o desempenho da LT em regime permanente considerando diversos aspectos e condições operativas. São eles: regulação, rendimento, ampacidade, perdas, efeito corona, influência do campo elétrico e magnético, e rádio interferência.

- Índices de mérito agregado: visam agregar as contribuições de dois ou mais fatores de desempenho.

Ressalta-se que a metodologia proposta poderá ser utilizada em qualquer linha de transmissão, com quaisquer configurações geométricas, níveis de tensão, ou condições ambientais.

A metodologia poderá ainda ser utilizada como uma referência para engenheiros, pesquisadores e estudantes, que buscam procedimentos para repotenciação de linhas de transmissão, conservando os requisitos técnicos mínimos (gerais, elétricos e mecânicos) estabelecidos pelas normas regulamentadoras.

\subsection{ORGANIZAÇÃO DO DOCUMENTO}

Para atingir o objetivo anteriormente citado e melhor expor as etapas e procedimentos, a presente dissertação será dividida em cinco capítulos, sendo o primeiro, a introdução, com apresentação do contexto, definição do problema, e objetivos .

O segundo capítulo apresentará o estado atual das pesquisas sobre repotenciação de linhas de transmissão, publicações recentes de estudos, trabalhos já executados na área, e alguns conceitos importantes para repotenciação de linhas de transmissão, salientando fatores como fenômenos que normalmente ocorrem na transmissão de energia elétrica e as técnicas utilizadas na repotenciação de linhas de transmissão.

No terceiro capítulo será apresentada a metodologia utilizada na pesquisa, delineando o processo sequencial da repotenciação através de um fluxograma. Com este será possível entender o processo de verificação das características de uma LT, com suas condições 
favoráveis ou não para a repotenciação, e a importância da formação de um qualitativo banco de dados da LT sob análise. Nesse capítulo, ainda serão propostos e apresentados os procedimentos de cálculo dos fatores de desempenho, e os índices de mérito agregado, que são requisitos principais da metodologia proposta.

No quarto capítulo será executada a metodologia apresentada no terceiro capítulo, com apresentação das características da linha de transmissão objeto de estudo, as técnicas de repotenciação convenientes para utilização na LT, a modelagem e as simulações computacionais para análise do fluxo de carga da LT sob condições de repotenciação em regime permanente. Também nesse capítulo serão ilustrados os resultados dos cálculos dos fatores de desempenho e dos índices de mérito agregado, com apresentação de gráficos, tabelas e pareceres das simulações. O quarto capítulo aborda ainda, a análise de todos os fatores de desempenho e dos índices de mérito agregado propostos na metodologia, identificando a necessidade ou não de mudanças na estrutura da LT, e consequentemente a escolha das técnicas mais eficientes para repotenciação da LT. Finalizando esse capítulo, será feita uma análise da LT repotenciada perante curtos-circuitos, agregando a metodologia informações sobre possíveis equipamentos superados e/ou com necessidade de readequação, como os disjuntores da LT. Logo ainda é possível, a atualização de dados de curto-circuito do sistema elétrico envolvido.

Para a conclusão desta dissertação, são apresentados no quinto capítulo os principais resultados da linha repotenciada, sobretudo considerações pertinentes à metodologia utilizada para atingir os objetivos da repotenciação de linhas de transmissão, destacando os princípios que facilitaram a definição da melhor técnica de repotenciação para a LT em estudo, e suas contribuições para pesquisas da área de sistemas elétricos de potência. Neste capítulo ainda serão feitas considerações sobre os impactos na LT repotenciada pelas diversas técnicas e sob regime de curto-circuito. 
$\mathrm{Na}$ parte final da dissertação será apresentada uma sequência de anexos que registram as seguintes informações:

Anexo A: Informa o banco de dados da linha de transmissão utilizada nos estudos propostos da dissertação, contendo parâmetros elétricos, geométricos, condições operativas dos equipamentos, características técnicas, dentre outros.

Anexo B: Este anexo apresenta como foram colhidas as amostras das simulações computacionais, e a utilização destas, nos procedimentos de cálculo dos fatores de desempenho e dos índices de mérito agregado.

Anexo C: Informa os requisitos mínimos para linhas de transmissão, onde são apresentados os cálculos do isolamento à máxima tensão operativa da LT, as distâncias de segurança entre partes vivas e as estruturas e o cálculo do número de isoladores com seus respectivos espaçamentos.

Anexo D: Este anexo registra, através de tabelas, todas as grandezas colhidas nas simulações de curto-circuito. As tabelas são divididas conforme o tipo de falta aplicada, localização da falta e características específicas da LT, como a inserção de resistência de falta. As tabelas registram as informações de todas as técnicas de repotenciação utilizadas nas simulações, que subsidiarão as definições e sínteses sobre curtos-circuitos.

Anexo E: Este anexo informa as publicações conseguidas referentes a este trabalho em seminários e simpósios da área de sistemas elétricos de potência. 


\section{Capítulo 2}

\section{Repotenciação de Linhas de Transmissão de Energia Elétrica}

\subsection{EXPERIÊNCIAS JÁ EXECUTADAS COM REPOTENCIAÇÃO DE LINHAS DE TRANSMISSÃO}

Segundo Oliveira (2000) a repotenciação de linhas de transmissão vem sendo adotado por várias empresas concessionárias de transmissão de energia, devido à relação custo-benefício apresentada, quando comparada à construção de uma linha nova.

No contexto apresentado por Wiedmer et al. (2007), relata-se a experiência de repotenciação realizada em três linhas de transmissão de 138 kV da Companhia Paranaense de Energia (COPEL), situadas na região central do Estado do Paraná, totalizando um trecho de 153,4 km de extensão. Nesse projeto foram analisadas algumas alternativas para o aumento da potência a ser transmitida, como a construção de novas linhas de transmissão no mesmo trecho, a substituição total das linhas existentes por outras de maior capacidade, a substituição dos condutores atuais por outros condutores de maior seção, e o lançamento de mais um condutor por fase. Entretanto, várias questões descartaram algumas alternativas, tais como restrições ambientais, o alto custo da construção de novas linhas, o peso adicional não suportado dos novos condutores pelas estruturas em operação, e o aumento demasiado da flecha do condutor existente sob elevação natural da tensão. A melhor solução encontrada para essa experiência foi então substituir os condutores CAA 266,8 KCM-Partridge por cabos CAL (cabos de liga de alumínio - AAAC - all aluminum alloy conductor), 312,8 KCM-Butte, constituídos de um condutor homogêneo encordoado concentricamente e formado por fios de alumínio liga 6201, sem alma de aço. Este cabo possui o mesmo diâmetro e praticamente a mesma ampacidade do cabo CAA Partridge, conservando uma mesma temperatura de 
operação, porém, com peso unitário menor. Esta configuração possibilitou menores flechas para o novo cabo, não necessitando de torres adicionais ao longo das linhas de transmissão. Contudo, pôde-se utilizar o carregamento máximo da LT para a tensão de $138 \mathrm{kV}$, que antes estava limitado pelas maiores flechas dos cabos envelhecidos. A utilização de um programa computacional específico, PLS CADD (2006), foi fundamental para a adoção desta técnica, pois com este foi determinado o tracionamento mecânico médio ao qual estavam submetidos os condutores Partridge, que na maior parte dos vãos estava na ordem de $20 \%$ da tração de ruptura na EDS (do inglês, Every Day Stress - estado de tração em que o condutor é submetido normalmente). Com esta modelagem, determinou-se que em alguns vãos, na temperatura de projeto de $55^{\circ}$ Celsius, o condutor CAA existente já não atendia as alturas de segurança cabo-solo. Os cabos de alumínio, de liga 6201, tipo CAL (AAAC) foram mais eficientes, proporcionando uma temperatura máxima nos cabos de $75^{\circ} \mathrm{C}$, uma menor flecha do condutor, tendo um ganho de altura cabo-solo, enquadrando-se nos limites normativos. Além disso, ensaios de vibração também foram executados em laboratório, possibilitando a determinação do melhor posicionamento dos amortecedores das linhas, o que garantiu níveis vibracionais dentro dos limites normativos, diminuindo também o processo de fadiga entre o cabo e seu suporte.

Em Stephan e Costa (2007) é apresentada a experiência da Eletrosul na repotenciação de linhas de transmissão em tensões de 138, 230 e $500 \mathrm{kV}$, sintetizando os principais procedimentos para análise e verificação da adequação de uma LT sob processo de repotenciação. Os trabalhos foram executados nas seguintes linhas de transmissão: LTs 230 kV Joinville-Curitiba - Curitiba I e II (200 km), LTs 230 kV Areia - São Mateus (120 km) e Salto Osório - Campo Mourão (380 km). LTs 138 kV Porto Primavera - Ivinhema $(75 \mathrm{~km})$ e Ivinhema - Dourados $(80 \mathrm{~km})$, totalizando aproximadamente $860 \mathrm{~km}$ de linhas de transmissão. Nesses projetos destacaram-se os procedimentos efetuados durante as fases de 
estudo de viabilidade técnico-econômica, anteprojeto, projeto e construção das LTs passíveis de repotenciação, bem como os principais aspectos das metodologias utilizadas para tal, como segue:

- Repotenciação por recondutoramento da linha de transmissão: essa técnica foi utilizada em três linhas de $230 \mathrm{kV}$, de aproximadamente $170 \mathrm{~km}$ de extensão, que utilizavam cabos ACSR 636 MCM Grosbeak. Inicialmente foram consideradas duas alternativas, sendo a primeira a troca de cabos condutores por outros de maior bitola, e a segunda alternativa, a troca dos cabos condutores por cabos condutores termorresistentes (TACSR) de mesma bitola. A primeira alternativa foi descartada, pois se os condutores fossem substituídos por outros de maior bitola, resultaria na sobrecarga das estruturas existentes, visto que as linhas foram construídas há mais de trinta anos. Então a segunda alternativa foi adotada, sendo que o novo cabo termorresistente possibilitou o aumento da potência transmitida de 270 para 350 MVA em cada linha. Ao final do projeto constatou-se que não haveria necessidade de reforçar fundações das LTs, sendo necessário apenas reforçar poucos suportes das mesmas, garantindo as premissas básicas de projeto (condições mecânicas, desempenho sob descarga atmosférica, trações de EDS), conforme a NBR 5422 (1985).

- Repotenciação por aumento de tração nos cabos condutores: nesse procedimento efetuou-se a análise estrutural dos suportes das LTs, e, posteriormente, foram executados reforços julgados necessários. A metodologia consistiu em aumentar a tração nos cabos condutores, e, consequentemente, diminuir as flechas, o que garantiu um aumento de capacidade de duas linhas de $138 \mathrm{kV}$ e uma de $230 \mathrm{kV}$, que antes somavam 327 MVA, e depois da repotenciação aumentou para 435 MVA. 
- Repotenciação motivada pelas substituições de cabos para-raios originais por cabos para-raios OPGW (do inglês, Optical Ground Wire): a utilização de cabos para-raios com fibras ópticas, denominados cabos OPGW, são uma alternativa à utilização de cabos ópticos enterrados e/ou cabos autossustentados. Essa metodologia foi utilizada na Eletrosul através de convênios com empresas de telecomunicação, como Brasil Telecom, Embratel e Eletronet. Para a utilização da infraestrutura existente, foram exigidas verificações que assegurassem a confiabilidade das linhas de transmissão e das subestações envolvidas no projeto. As empresas executantes do projeto efetuaram a análise estrutural de todas as torres para os novos carregamentos, e em algumas linhas foram necessários reforços nas estruturas, devido à insuficiência de resistência mecânica de alguns membros estruturais. Em alguns casos foram atribuídas torres auxiliares nas LTs.

Os tipos de cabos OPGW utilizados nesse projeto foram os seguintes:

○ Cabo Alcoa $\left(57 \mathrm{~mm}^{2}\right)$ com diâmetro $11,8 \mathrm{~mm}$ e peso $4,50 \mathrm{kN} / \mathrm{Km}$

○ Cabo Furukawa $\left(54 \mathrm{~mm}^{2}\right)$ com diâmetro $11,5 \mathrm{~mm}$ e peso $4,3 \mathrm{kN} / \mathrm{Km}$

○ Cabo Pirelli com diâmetro $16,4 \mathrm{~mm}$ e peso $9,09 \mathrm{kN} / \mathrm{Km}$

O autor concluiu que essa metodologia propicia facilidade de manutenção da LT, a confiabilidade do sistema, a conservação da função original dos cabos para-raios, o reaproveitamento do percurso entre os terminais, e ganho nos sistemas de comunicação.

- Repotenciação motivada pela adequação de linhas de transmissão existentes aos novos carregamentos preconizados pelas normas NBR 5422, (NBR 5422, 1985) e IEC 60826, (IEC 60826, 2003). Com a criação da Agência Nacional de Energia Elétrica (ANEEL) em dezembro de 1996, os carregamentos foram preconizados pela NBR 5422 e IEC 60826, havendo a necessidade de adequação das LTs que estavam fora dos padrões dessas normas. Um trabalho de análise estrutural foi 
realizado utilizando-se de um programa computacional baseado em elementos finitos, sendo que os suportes foram considerados como treliças espaciais. O elemento finito considerado foi um elemento barra, e as forças atuantes foram consideradas nos nós das barras. Segundo Stephan e Costa (2007), os dimensionamentos das barras e também das ligações foram executados de acordo com as recomendações e exigências do "Guide for Design of Steel Transmission Towers" da ASCE $n^{\circ}$ 52, (ASCE, 1988) e da NBR 8850, (NBR 8850, 1985). Assim, os reforços necessários das estruturas foram realizados, em sua maioria, com as LTs energizadas, considerando uma série de premissas (sequência de montagem, apertos, desmontagem, supervisão) que garantiram a segurança da frente de trabalho e da sua operação contínua. Esta metodologia exigiu também a verificação estrutural e geotécnica de todas as fundações dos suportes das linhas de transmissão, para garantia e adequação aos limites de segurança.

Finalmente o autor recomendou a elaboração de um documento, mesmo que sem caráter normativo, que descrevesse os procedimentos a serem seguidos para a repotenciação de linhas de transmissão, devido à grande diversidade de procedimentos e critérios adotados no Brasil para trabalhos desta natureza.

Silva et al. (2001) abordam os procedimentos utilizados pela Eletrobrás/Furnas na recapacitação de LTs de $138 \mathrm{kV}$, que necessitavam de aumento de potência e tinham como principal característica os cabos baixos em relação ao solo, em consequência das flechas apresentadas devido a elevadas temperatura nestes. Inicialmente foram efetuados estudos de topografia para verificar as condições em que as LTs se encontravam em relação ao número de vãos, tipo e altura das estruturas, comprimento dos vãos, desníveis, coordenadas dos pontos críticos e dos obstáculos atravessados pelas LTs, e a cota dos cabos das fases inferiores sobre cada ponto crítico ou obstáculo. A metodologia usada para a análise da situação em que 
a LT se encontrava, e a definição das modificações necessárias, compreendeu as seguintes etapas:

a) Com base nos dados levantados em campo, calculou-se para cada comprimento dos cabos entre duas ancoragens, a mudança de estado devida à flecha ocorrida, a partir da tração de lançamento provocada pelo peso destes.

b) Após o cálculo da flecha, calculou-se, de acordo com a mesma metodologia, a mudança de estado para diversas temperaturas acima da temperatura máxima de projeto, até os limites de temperatura especificados. A distância do condutor até os obstáculos levantados também foi calculada.

c) Com base nesses cálculos, foram identificados os vãos que necessitam de modificações para atenderem às distâncias mínimas nas temperaturas especificadas para a condição normal e de emergência.

d) Em seguida, foram simuladas as modificações necessárias nas estruturas para permitir a operação do tramo considerado nas temperaturas máximas especificadas. As modificações foram feitas de modo a garantir a distância mínima entre fases.

As distâncias de segurança verticais foram calculadas de acordo com a NBR 5422, e pela utilização de um programa computacional, empregando o conceito de vão equivalente. Este conceito caracteriza-se como a variação da carga de tração, de todos os vãos de um tramo, e entre duas ancoragens, sendo igual à variação ocorrida no vão equivalente, sujeito a qualquer variação de carregamento (temperatura, vento, flecha).

As principais modificações apresentadas em algumas estruturas foram:

- A substituição de uma cadeia de suspensão por uma ancoragem móvel; 
- O corte de um segmento de cabo juntamente com a instalação de ancoragem móvel. O corte pode ser feito de um ou ambos os vãos e com comprimentos diferentes;

- A supressão de um ou dois isoladores nas cadeias de ancoragem.

Assim, os autores concluíram que a metodologia adotada apresentou uma elevada relação custo-benefício, além de um tempo de implementação reduzido.

Gabaglia et al (2001) apresentam uma análise e comparações de desempenho entre as ferragens desenvolvidas para utilização na recapacitação das linhas de transmissão de $500 \mathrm{kV}$ de Furnas e a ferragem tradicional de 18 polegadas, obtidas a partir dos resultados de ensaios de laboratório realizados no CEPEL. O conceito aplicado para o trabalho é a tecnologia Linhas de Potência Natural Elevada (LPNE), em que Furnas, CHESF e CEPEL atestam seu domínio, e utilizam ainda a expansão dos feixes das fases - LPNE/FEX para recapacitação de linhas de transmissão de $500 \mathrm{kV}$. A característica principal adotada para esta metodologia de repotenciação é a alteração do arranjo das fases, que para as torres de 500 kV tipo A54 "cara de gato" (ver Figura 2-1), com arranjo de feixes tradicional (três subcondutores por fase, tipo RAIL-954 MCM, feixe de 18 polegadas ou espaçamento entre subcondutores de $457 \mathrm{~mm}$ ), passaram para uma configuração de quatro subcondutores por fase, tipo RAIL-954 MCM, com espaçamento entre subcondutores de $1.050 \mathrm{~mm}$ na fase central e $1.170 \mathrm{~mm}$ nas fases externas. Com a nova configuração, os testes de laboratório confirmaram um ganho de cerca de $30 \%$ na potência natural sobre o projeto original de três subcondutores. No laboratório ainda foram realizados ensaios de tensão de rádio interferência, corona visual, distribuição de potencial ao longo da cadeia de isoladores, tensão suportável de impulso atmosférico e de manobra, no intuito de verificar os limites operativos destes. 


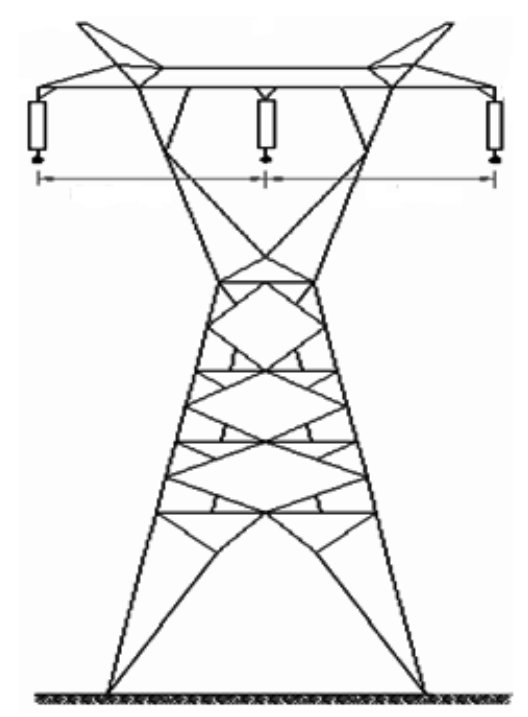

Figura 2-1 - Torre tipo A54.

Os ensaios de tensão de rádio interferência foram realizados por um programa computacional chamado TRICAMP, de acordo com Domingues et al (2000).

Os resultados dos ensaios para a determinação do efeito corona visual apresentados em Gabaglia et al (2001) foram positivos, pois para a nova configuração da LT, o corona visual surgiu apenas para tensões $40 \%$ superiores à tensão de ensaio. Tal condição foi justificada pela melhor distribuição de campo elétrico na nova configuração. Para os ensaios de distribuição de potencial ao longo da cadeia de isoladores, pode-se observar para o feixe LPNE/FEX a diminuição dos valores percentuais do potencial dos primeiros e últimos isoladores em relação ao feixe de 18 polegadas, permitindo uma melhor distribuição do potencial em toda cadeia. Já nos ensaios de tensão suportável ao impulso atmosférico e impulso de manobra, os resultados foram equivalentes entre estruturas de LPNE/FEX, e a estrutura de ferragens de 18 polegadas, condição que aprova a nova configuração em teste, observando ainda que as descargas ocorridas sempre foram absorvidas pelas ferragens LPNE/FEX, protegendo a cadeia de isoladores. Os autores concluíram que o desempenho desta técnica é altamente satisfatório, como observado nos ensaios, ressaltando uma vantagem adicional de proteger os primeiros isoladores da cadeia. Esta característica facilita a 
manutenção da linha viva, uma vez que, dependendo do projeto da ferragem, os primeiros isoladores da cadeia ficam blindados por estarem no interior do feixe.

Em Oliveira (2000), a autora reconhece que existe uma dificuldade muito grande para constituição de novas faixas de passagem e licenciamentos de obras, devido à questão ambiental, dificultando assim construção de novas linhas de transmissão de energia elétrica. Essas dificuldades, juntamente com a elevação progressiva do carregamento das linhas de transmissão, motivaram a autora a apresentar alternativas de técnicas de recapacitação de linhas de transmissão, segundo a ótica do dimensionamento elétrico e da determinação das distâncias mínimas de coordenação de isolamento necessárias na torre, visando maximizar a energia transportada por área ocupada pela faixa da linha de transmissão. A autora conclui que a recapacitação é otimizada quando se constrói previamente um banco de dados com as características gerais predominantes na LT e do ambiente em que ela está submetida. Entre as técnicas apresentadas pela pesquisa, a alteração do limite térmico da linha ou a mudança da tensão nominal da LT estão em vantagem em relação às demais, devido a não necessidade do desligamento da linha para a implementação. Ressalta-se que várias técnicas de repotenciação apresentadas pela autora serviram de base para as simulações propostas na presente dissertação.

Vale ressaltar que a presente dissertação poderá contribuir com os projetos apresentados neste capítulo, pois servirá como complemento ou auxílio na definição da melhor solução para as linhas de transmissão em estudo, considerando as várias técnicas possíveis para a repotenciação, sobretudo do ponto de vista técnico e operação em regime permanente. 


\subsection{CONCEITOS PARA REPOTENCIAÇÃO DE LINHAS DE TRANSMISSÃO}

Alguns conceitos importantes para melhor entender aspectos relacionados à transmissão de energia elétrica e para as análises de uma LT sob processo de repotenciação serão apresentados neste capítulo.

\subsubsection{Carga natural ou potência natural}

Segundo Bezerra (1998), a potência natural ou SIL (Surge Impedance Loading) é definida como a potência entregue por uma LT ideal (sem perdas). Inicialmente a impedância característica $Z_{C}$ é definida conforme a equação (2.1).

$$
Z_{C}=\sqrt{\frac{r+j w l}{g+j w c}}[\Omega]
$$

Os parâmetros da impedância característica da LT são definidos por unidade de comprimento, sendo:

$$
\begin{aligned}
& r\left[\frac{o h m s}{k m}\right]=\text { resistência da LT } \\
& g\left[\frac{s}{k m}\right]=\text { condutância da LT } \\
& l\left[\frac{H}{k m}\right]=\text { indutância da LT } \\
& c\left[\frac{F}{k m}\right]=\text { capacitância da LT }
\end{aligned}
$$

Considerando que " $r$ " e " $g$ " são muito pequenos diante dos demais parâmetros, a impedância característica pode ser considerada igual à impedância natural da linha de transmissão. Logo, $Z_{C}=Z_{0}$, passando a ser denominada de impedância natural da linha.

$$
Z_{0}=\sqrt{\frac{l}{c}}
$$


Ao estabelecer que a carga está submetida a uma tensão $V r$ (tensão no terminal receptor) e apresenta impedância $Z_{0}=\sqrt{l / c}$, determina-se a potência natural da LT ou SIL. Assim, tem-se o SIL definido por (2.3).

$$
S I L=P_{0}=\frac{|V r|^{2}}{Z_{0}}[W]
$$

Portanto, a potência reativa que flui em uma linha sem perdas operando à potência natural é nula e a potência real permanece constante entre os terminais do transmissor e receptor.

A equação (2.3) expressa que a potência natural de uma linha de transmissão é diretamente proporcional ao quadrado da tensão no terminal receptor e inversamente proporcional à impedância característica da linha quando desprezados " $r "$ e " $g$ ".

Se a tensão de uma linha é duplicada, i.e., $2 V r$, tem-se que a potência natural da linha $P_{0}$, torna-se quatro vezes maior.

$$
S I L=\frac{(2 V r)^{2}}{Z_{0}}=4 P_{0}
$$

Nas análises para definição da classe de tensão da LT, procura-se compatibilizar a tensão nominal da nova linha de transmissão com a potência elétrica a ser transmitida. Um dos critérios utilizados nesta escolha é através da potência natural da LT, conforme a equação $(2.5)$.

$$
\text { Vnom }=\sqrt{P_{0} \cdot Z_{0}}
$$

A Tabela 2-1 relaciona valores do SIL e impedância de surto para diversos valores de tensão nominal utilizado nas linhas de transmissão, conforme Bezerra (1998). 
Tabela 2-1 - Valores típicos de impedância de surto e potência natural para linhas aéreas trifásicas em $60 \mathrm{~Hz}$ (Bezerra, 1998)

\begin{tabular}{|c|c|c|}
\hline Vnom $(k V)$ & $Z_{C}=\sqrt{l / c}(\Omega)$ & $S I L=V^{2}$ nom $/ Z_{C} \quad(M W)$ \\
\hline 69 & $366-400$ & $12-13$ \\
\hline 138 & $366-405$ & $47-120$ \\
\hline 230 & $365-395$ & $134-145$ \\
\hline 345 & $280-366$ & $325-425$ \\
\hline 700 & $233-294$ & $850-1075$ \\
\hline 765 & $254-266$ & $2200-2300$ \\
\hline
\end{tabular}

A potência natural ou SIL é uma referência recomendável para um correto dimensionamento de uma LT, pois é uma característica que facilita os cálculos de limites operativos da mesma.

\subsubsection{Máxima transferência de potência de uma linha de transmissão}

Em um sistema de potência em regime permanente, ou em equilíbrio, à medida que se aumenta a carga, acarretam-se consecutivamente, aumentos graduais na energia transmitida pela linha em consideração. A quantidade de potência que flui em um circuito depende do nível da tensão, da diferença de ângulo de fase entre seus terminais e da impedância do circuito, desprezada a parte resistiva, já que esta possui valores muito baixos comparados com a reatância da LT, conforme ilustra a Figura 2-2.

Barra 1

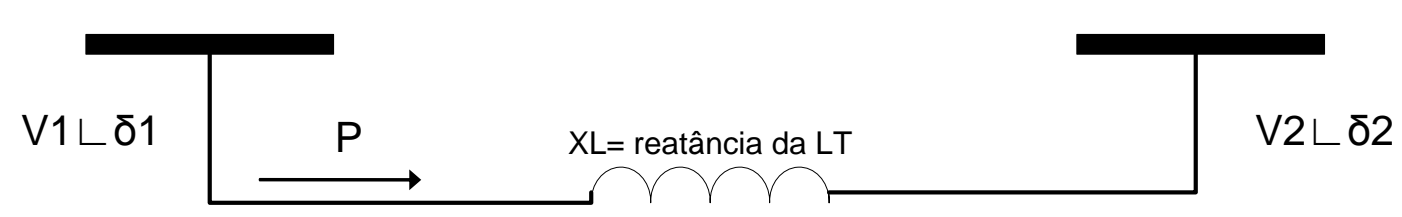

Figura 2-2 - Fluxo de potência em uma LT

A potência natural " $P$ " transmitida pela linha de transmissão é dada pela equação (2.6).

$$
P=\frac{V 1 \cdot V 2}{X L} \cdot \operatorname{sen} \delta
$$


onde:

$\delta=\delta 1-\delta 2$, é o ângulo de carga da linha e corresponde à diferença angular das tensões entre um terminal e outro;

$V 1$ e V2 são magnitudes da tensão nas barras 1 e 2, respectivamente;

$\delta 1$ e $\delta 2$ são os ângulos de fase de $V 1$ e $V 2$ com relação à determinada barra tomada como referência no sistema;

$X L$ é a reatância indutiva da linha de transmissão.

A equação (2.6) é conhecida como equação de transferência de potência, tendo grande utilidade na compreensão do comportamento do sistema elétrico, sobretudo da influência da tensão nas barras, da reatância da LT e das variações do ângulo de carga (Furnas, 2000).

\subsubsection{Limite de estabilidade}

O limite de estabilidade representa o máximo fluxo possível de energia que pode fluir por uma LT, quando o sistema elétrico na qual ela faz parte está funcionando de maneira estável (Stevenson, 1978).

A aplicação do termo limite de estabilidade é adequada tanto para regime permanente quanto para regime transitório de uma LT. Limite de estabilidade em regime permanente refere-se ao máximo fluxo de potência possível considerando uma LT como um todo, operando sem perda de estabilidade quando a potência é aumentada gradualmente. O limite de estabilidade transitória refere-se ao máximo fluxo de potência possível na LT, sem perda de estabilidade, quando ocorre uma perturbação súbita na LT.

Considerando a equação da potência natural em grandezas reais (tensão em volts e reatância em ohms), chega-se à conclusão que a potência transmitida é diretamente proporcional ao quadrado da tensão e ao defasamento angular, sendo também inversamente proporcional à reatância da linha. 
Deve-se lembrar de que a reatância $X L$ não muda apreciavelmente ao passar de um nível de tensão para outro, uma vez que ela depende basicamente da geometria da linha e do espaçamento dos condutores.

Considerando as tensões nas barras 1 e 2 da Figura 2-2, como sendo constantes, então:

$$
P 12=P \max \cdot \operatorname{sen} \delta
$$

Sendo:

$$
P \max =\frac{V 1 \cdot V 2}{X L}=c t e
$$

Neste caso, a única maneira de alterar a magnitude da potência sendo transmitida pela linha será através do ângulo de carga $\delta$.

Com o ângulo de carga em $\delta=90^{\circ}$, a potência transmitida atinge seu valor máximo, e esta condição é conhecida como limite de estabilidade estática (Furnas, 2000). Qualquer tentativa de transmissão acima deste limite pode resultar em um colapso de tensão na LT.

Resumindo, conforme a equação de transferência de potência, a capacidade de transmissão de potência em qualquer circuito pode ser aumentada de três formas distintas:

- Aumentando-se as tensões em qualquer das extremidades do circuito, ou em ambas, inclusive através do aumento da tensão nominal;

- Reduzindo a impedância do circuito;

- Aumentando-se o ângulo de carga do circuito até seu limite máximo de $90^{\circ}$.

\subsection{TÉCNICAS DE REPOTENCIAÇÃO}

Como já salientado em Oliveira (2000), a busca por alternativas que possibilitem uma maior transmissão de energia pelas linhas de transmissão em operação recebe várias denominações tanto no exterior quanto no Brasil, sendo citadas como: refurbishment, recapacitação, line upgrade e repotenciação. 
Independente da nomenclatura utilizada, as técnicas para repotenciação de linhas de transmissão requerem ações estruturadas, devido à variedade de normas e detalhes técnicos a serem observados ao mesmo rigor de um projeto de construção de uma LT nova. Algumas dessas técnicas são brevemente descritas nos itens seguintes.

\subsubsection{Alteração do Limite Térmico da Linha de Transmissão}

Segundo Oliveira (2000), o limite térmico do condutor está associado à perda das características mecânicas do mesmo (recozimento do condutor), implicando diretamente na diminuição da elasticidade e na formação das flechas. Neste contexto, o limite térmico da LT se associa à maior temperatura que a linha pode atingir sem violar as alturas de segurança dos condutores ao solo, que são estabelecidas por normas técnicas para os diversos tipos de travessia, NBR5422 (1985). A temperatura dos cabos está relacionada à influência do vento, à temperatura ambiente e à radiação solar, estabelecendo ainda uma relação direta com a corrente e potência da LT.

O aumento do limite térmico da LT traz benefícios consideráveis para a transmissão de energia elétrica, pois existe uma relação direta entre temperatura, corrente e potência transmitida. Uma maior condição de carregamento da LT, ou maior potência transmitida pode ser conseguida através da utilização de cabos termorresistente (TAL), que consistem em uma liga onde são acrescentados alguns aditivos ao alumínio. Estes cabos permitem então uma maior passagem de corrente, pois suportam temperaturas mais elevadas, sem perda de suas características mecânicas (tração, alongamento e dureza).

Na repotenciação de uma LT pode-se elevar o limite térmico dos cabos condutores, sem a necessidade de troca destes, pois o cabo muitas vezes opera com temperatura abaixo de seu limite térmico real. Em casos como esse é importante observar que a flecha apresentada pelo condutor aumentará acarretando a diminuição da distância entre cabo-solo, e então existe 
a necessidade de retensionamento dos cabos, modificação da cadeia de isoladores, ou até aumento da altura das torres.

Assim, a temperatura da LT deve ser limitada a um valor que não cause danos ao condutor, podendo ser monitorada pela relação corrente/temperatura.

\subsubsection{Recondutoramento da Linha de Transmissão}

Esta técnica consiste na troca total dos condutores da LT por outros de maior seção, ou por cabos termorresistente, o que aumenta a capacidade de transporte de corrente na LT, segundo apresentado em Oliveira (2000). Este processo requer a realização de estudos de carregamentos mecânicos, esforços transversais e longitudinais nas estruturas da LT, devido geralmente ao aumento de peso do condutor. Para esta técnica é conveniente verificar individualmente os esforços das estruturas e diagnosticar a viabilidade técnica do processo.

Outra vertente seria a substituição do condutor ou dos condutores por outros com características construtivas diferentes, mas que mantenham as mesmas condições mecânicas do condutor anterior, evitando a necessidade de reforço nas estruturas.

\subsubsection{Lançamento de mais Subcondutores por Fase na Linha de Transmissão}

Esta técnica é caracterizada pela adição de um ou mais condutores nas fases, também chamados de subcondutores de um feixe. Os condutores podem ter bitolas diferentes em um mesmo feixe conforme abordado em Da Costa (2009), caso se detecte que haja uma melhor distribuição de correntes entre eles, e consequentemente menores perdas por efeito Joule.

Um dos fatores limitantes para esta técnica é o limite de carregamento mecânico para as estruturas, que muitas vezes devem ser modificadas para atenderem aos novos pesos dos cabos, acarretando custos nem sempre viáveis. 


\subsubsection{Modificação da Tensão Operativa da Linha de Transmissão}

Em Oliveira (2000) afirma-se que esta alternativa consiste no aumento da tensão operativa da LT, ocasionando uma redução da corrente da LT para transmitir o mesmo montante de potência. Como consequência, pode-se conseguir um ganho substancial na capacidade de transmissão da LT repotenciada, mesmo sem o recondutoramento ou lançamento de cabos auxiliares.

A principal característica desta técnica é o estudo das distâncias de isolamento da LT, que com a alteração da tensão, tais valores de isolamento podem ser diferentes dos originais. A possibilidade de alteração da cadeia de isoladores se caracteriza como ponto de restrição, juntamente com a instalação de novos equipamentos nas subestações, adequados ao novo nível de tensão.

O emprego desta técnica deve ser bem avaliado, pois sua utilização pode acarretar a troca e/ou adição de novos equipamentos (transformadores, barramentos, transformadores de potência, transformadores de corrente, disjuntores, seccionadoras, reatores, etc..) ao sistema envolvido com a LT, sendo que normalmente estes são mais caros que os já existentes. Assim uma análise do sistema elétrico envolvido deve ser efetuada, considerando benefícios de curto até longo prazo. Os principais fatores que estimulam a adoção desta técnica são a alta potência conseguida após a repotenciação, condições estratégicas de escoamento da potência de tal sistema, aproveitamento de equipamentos já existentes nas subestações envolvidas e projetos futuros para as novas tensões.

\subsubsection{Repotenciação Híbrida}

Esta técnica consiste na junção de duas ou mais técnicas, visando encontrar o melhor desempenho para a operação em regime permanente da LT, ou identificar características diferenciais importantes para avaliação dos impactos de repotenciação de linhas de transmissão. Ressalta-se que a titulação híbrida se dá devido à união de diferentes técnicas de 
repotenciação, não sendo uma nomenclatura utilizada normalmente pelos pesquisadores, porém será bastante utilizada neste trabalho. 


\section{Capítulo 3}

\section{Metodologia de Análise}

Existem na literatura técnica alguns trabalhos apresentando metodologias para a avaliação do desempenho de linhas de transmissão de energia elétrica, em que são apontados os principais fatores a serem analisados nesses casos. Como exemplo de um desses trabalhos, Barbosa et al (2007) apresentam os fundamentos teóricos empregados para o desenvolvimento de uma ferramenta computacional capaz de determinar o campo elétrico na superfície dos condutores, a influência do campo elétrico e magnético na vizinhança da LT, o risco de falha por surtos de manobra, as perdas de energia, a radiointerferência e o ruído audível produzidos pelo efeito corona. Tomando como referência esse trabalho, nesta seção será proposta uma metodologia de análise objetivando avaliar o desempenho técnico das LTs após a repotenciação, independente do método empregado para aumentar sua capacidade de transmissão de energia elétrica.

A metodologia de análise proposta consiste em agrupar aos fatores mencionados no parágrafo anterior com outros fatores de desempenho, e depois compará-los com índices numéricos, chamados índices de mérito agregado (IMA). Estes índices são considerados eficazes para uma avaliação comparativa de diferentes técnicas de repotenciação de LTs. Os IMA incorporam informações sobre as variações no carregamento da LT e fatores limitantes de rendimento, regulação e estabilidade de tensão, que logo facilitarão a identificação da técnica de repotenciação mais vantajosa em termos de operação da LT em regime permanente. 
A avaliação da LT repotenciada frente a curtos-circuitos também será abordada como um complemento que possibilitará identificar os limites operativos de equipamentos, de acordo com níveis de corrente de curto-circuito simétrica nos terminais da LT e variações de tensão ao longo da mesma. Serão efetuadas simulações de curto-circuito, com faltas entre fases e faltas entre fase/terra ao longo da LT, inclusive com inserção de resistência de falta.

\subsection{FLUXOGRAMA}

O fluxograma apresentado pela Figura 3-1 mostra a metodologia proposta, sendo comentado consecutivamente.

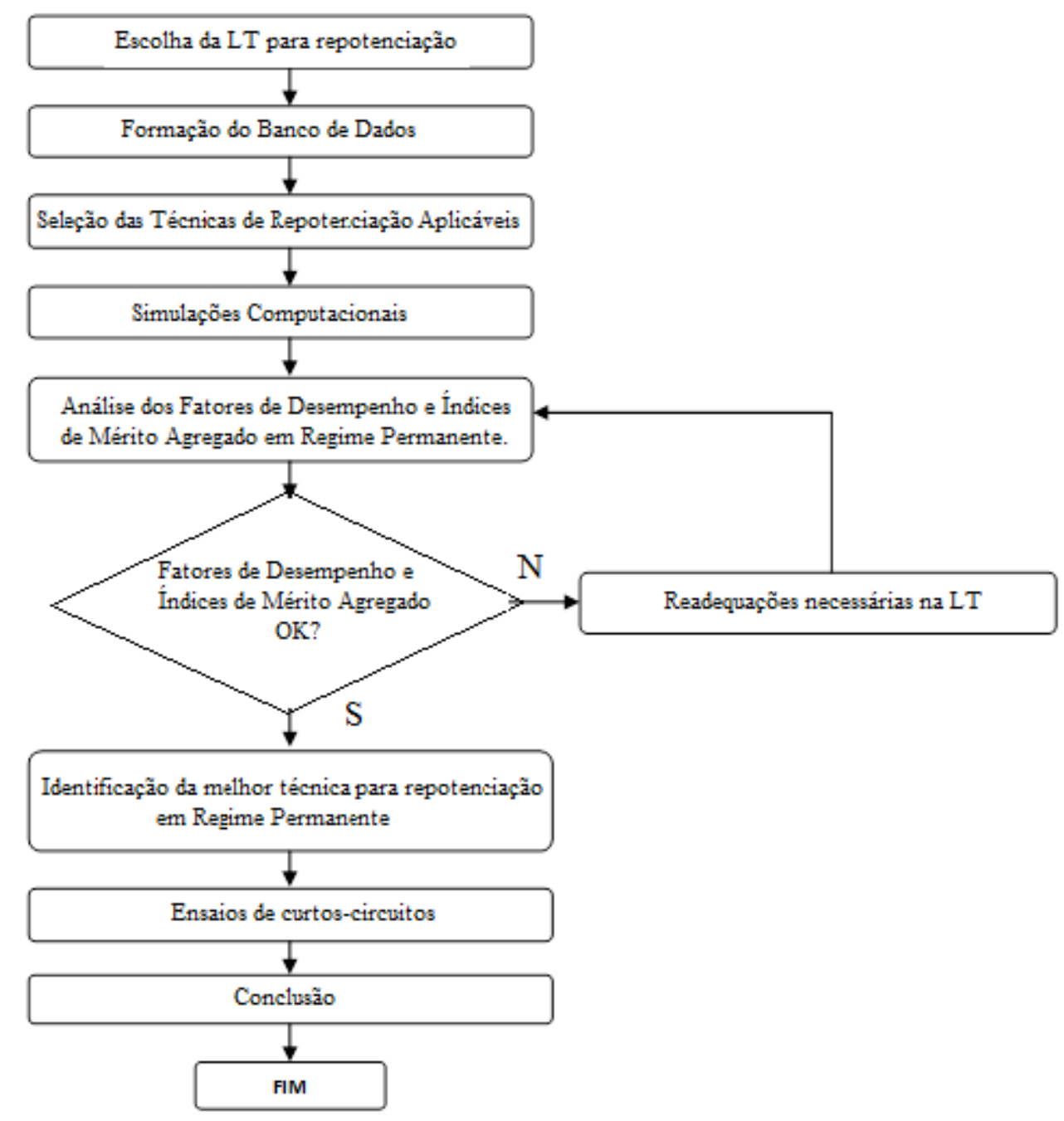

Figura 3-1 - Fluxograma da metodologia proposta 


\subsubsection{Escolha da LT para repotenciação}

Seguindo recomendações apresentadas em Biasotto (2009) e considerando a experiência de engenheiros e técnicos atuantes nas concessionárias responsáveis pela transmissão de energia elétrica, os seguintes fatores devem ser considerados na escolha de uma linha de transmissão a ser repotenciada.

- Limite da capacidade de transmissão de energia elétrica: inicialmente, deve-se avaliar se a capacidade de transmissão da LT está próxima do seu limite de projeto ou se esta será atingida em um curto espaço de tempo, dada a previsão do crescimento da demanda;

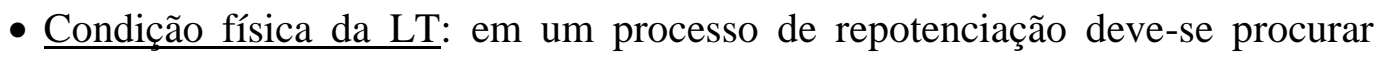
aproveitar, sempre que possível, o material já instalado na LT, visando à redução de custos. Por exemplo, o bom estado de conservação dos condutores implica em reaproveitamento dos mesmos, a depender da técnica de repotenciação escolhida. No entanto, uma característica destacada em Biasotto (2009) defende que linhas de transmissão com necessidades de melhorias em suas condições físicas podem ser consideradas prioritárias em um processo de repotenciação. A justificativa dessa afirmação é que a reforma da LT para adequar suas condições físicas pode ser realizada durante o processo de repotenciação. Ressalta-se que ambas as visões são válidas, mas a escolha da LT a ser repotenciada deve ser feita analisando o conjunto de fatores apresentados nesta seção e não um fator isolado;

- Derivações da LT: a repotenciação de linhas curtas e com o mínimo de derivações é um processo mais rápido e mais barato;

- Trajeto da LT: locais de difícil acesso para a realização das obras pode inviabilizar o processo de repotenciação.

\subsubsection{Formação do banco de dados}

É de suma importância ter acesso aos dados da LT necessários para a realização das análises descritas no início deste capítulo. A falta de certas informações leva ao emprego de 
dados típicos, os quais podem ser escolhidos sem o devido cuidado e podem gerar conclusões errôneas decorrentes das análises efetuadas. Portanto, segue uma lista das informações da LT necessárias para a análise de desempenho:

- Comprimento da LT e número de torres;

- Características dos condutores e cabos para-raios: bitola, resistência em corrente contínua, diâmetro, seção total, peso, tipo;

- Características dos circuitos: número de condutores por fase, configuração do feixe de subcondutores (quando for o caso) e flecha;

- Características geométricas da torre: distâncias horizontais e verticais entre cabos condutores e cabos para-raios, e entre esses cabos e o solo;

- Resistividade do solo;

- Cadeia de isoladores: número de isoladores, tipos e classe de tensão;

- Valores de projeto: corrente, temperatura, velocidade do vento, temperatura ambiente, pressão atmosférica, altitude;

- Valores em emergência: corrente, tensão, temperatura.

- Equivalentes de curto-circuito nas subestações nas quais a linha está conectada: potência de curto-circuito monofásica e trifásica (potência ativa e reativa).

\subsubsection{Seleção das técnicas de repotenciação aplicáveis}

A escolha da técnica de repotenciação a ser aplicada em uma LT deve aliar aspectos técnicos e econômicos. Nesta dissertação não serão avaliados os aspectos econômicos, e reserva-se esse tema para trabalhos futuros, pois neste documento pretende-se evidenciar as diferenças de desempenho da LT repotenciada frente a várias técnicas de recapacitação. Logo, os resultados obtidos com o método de análise aqui apresentado fornecerão subsídios técnicos para que os engenheiros possam determinar a relação de custo-benefício dos métodos de repotenciação, quando estudos econômicos forem realizados. 
Os aspectos abaixo relacionados são considerados interessantes de serem observados, quando da escolha da técnica de repotenciação a ser utilizada.

- Dimensões das estruturas: este fator, afeta diretamente as técnicas que envolvem a elevação da tensão operativa, o lançamento de mais um condutor por fase e alteração no feixe de subcondutores. A razão disso é que em qualquer uma dessas técnicas será necessário verificar se as distâncias de segurança horizontais e verticais continuam a ser respeitadas, sejam em condições normais de operação da LT repotenciada ou em condições de defeitos que provoquem sobretensões. Portanto, estruturas que apresentem uma folga adequada com relação às distâncias de segurança devem sofrer poucas adaptações, acarretando em menores custos da repotenciação;

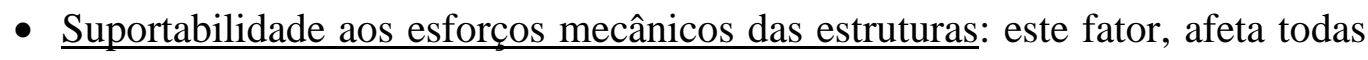
as técnicas de repotenciação mencionadas no capítulo anterior. Técnicas como recondutoramento, lançamento de mais um condutor por fase e modificações do feixe de subcondutores implicam diretamente na alteração do peso que a estrutura deve suportar. Além disso, em relação à técnica de elevação da classe de tensão, a estrutura deve suportar o peso dos isoladores para a nova tensão de operação. Logo, dada a estrutura da linha a ser repotenciada, sua capacidade de suportar esforços mecânicos pode ser um fator restritivo à aplicação de determinadas técnicas de repotenciação;

- Níveis de tensão disponíveis nos terminais da LT: este item é de suma importância para a técnica de repotenciação do aumento da classe de tensão operativa da LT. Devem ser observados os níveis de tensão existentes nas subestações nas quais a LT está conectada, de forma que, as modificações nessas subestações sejam às menores possíveis, visando reduzir os custos da repotenciação e o período de indisponibilidade da LT. Logo, caso não haja disponível o nível de tensão pretendida em uma subestação, a aplicação da técnica de elevação da classe de tensão pode se tornar inviável economicamente. 
- Aspectos ambientais: algumas técnicas de repotenciação podem requerer adaptações nas estruturas de forma a aumentar a faixa de passagem da LT. Esta é uma situação indesejável, pois deve ser requerida uma nova licença ambiental. Portanto, é recomendado que, observando-se o tipo de estrutura da linha, a técnica de repotenciação a ser selecionada não viole restrições ambientais.

\subsubsection{Simulações computacionais}

Com a grande variação de arranjos físicos de sistemas de transmissão, é necessário, para uma modelagem precisa de uma LT, considerar a natureza distribuída dos parâmetros e a dependência destes com a frequência. Desta forma, o modelamento da LT pode ocorrer de diferentes formas, de acordo com a precisão e eficiência que se busca.

Nesta dissertação foi utilizado o programa DIgSILENT PowerFactory (DIgSILENT, 2010). Este programa foi desenvolvido como um pacote interativo e integrado de funções dedicadas a estudos de sistemas elétricos de potência, com intuito de otimizar o planejamento e operação destes. O programa DIgSILENT é componente integrante do pacote PowerFactory, projetado para analisar sistemas elétricos envolvendo geração, transmissão e distribuição de energia elétrica.

Este programa foi utilizado devido a sua interface que facilita as simulações de LTs, pois utiliza o circuito $\pi$ equivalente considerando parâmetros concentrados ou distribuídos, dependentes ou não da frequência. Ressalta-se que a precisão dos resultados é maior para o circuito $\pi$ com parâmetros distribuídos (circuitos em cascata), devido ao seu equacionamento considerar pontos distribuídos ao longo da LT (DIgSILENT 2010; Fuchs, 1979).

A Figura 3-2 ilustra o sequencial de como foi utilizado o programa nas simulações digitais. 


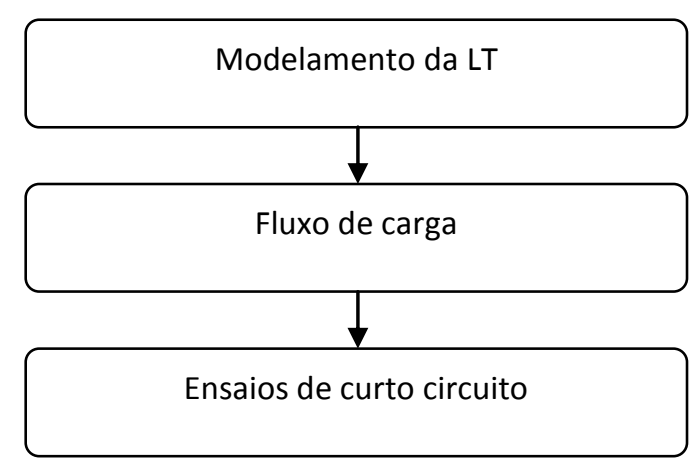

Figura 3-2 - Sequência de execução das simulações.

Modelamento da LT: O modelamento da LT é feito utilizando todos componentes físicos e elétricos do seu banco de dados. A Figura 3-3 apresenta a LT sob estudo, em que um dos terminais da linha foi considerado como um barramento infinito (Furnas), o que significa que a tensão no transmissor será fixa para todas as simulações realizadas. Os parâmetros da fonte que representa o barramento infinito foram calculados a partir das informações de nível de curto-circuito para o ano de 2009 na subestação Furnas, conforme ONS (2009). No terminal receptor (barramento de Poços de Caldas), foi conectada uma carga trifásica balanceada, representando uma situação real, cujos valores de potência ativa e reativa são variados conforme o fator de desempenho que se deseja avaliar, sendo mantido um fator de potência de 0,95, escolhido por representar uma condição otimizada e desejada de desempenho. Nesse modelo foi considerada a linha transposta, conforme o projeto original.

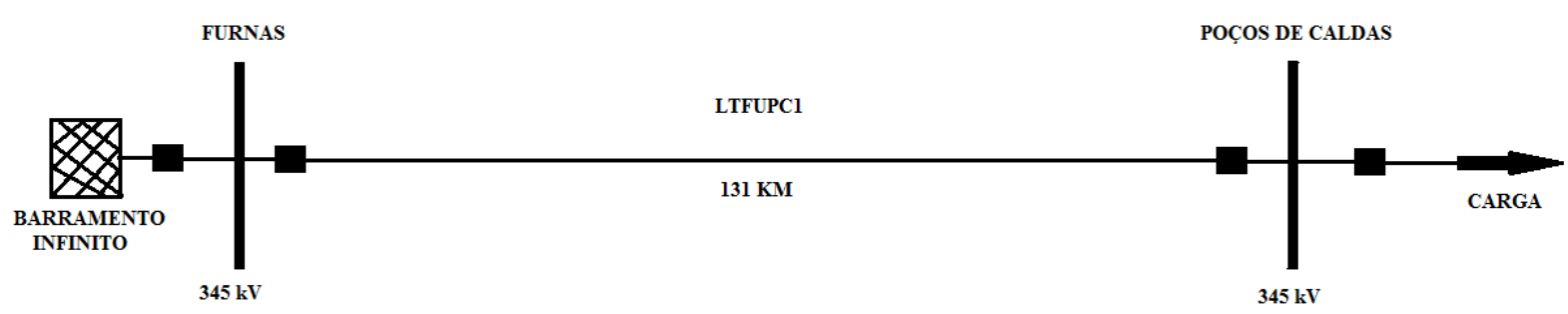

Figura 3-3 - Modelamento da LT para fluxo de carga

A Tabela 3-1 apresenta os dados do barramento infinito conectado à subestação de Furnas, para as simulações em 345 e 500 kV, conforme ONS (2009). 
Tabela 3-1 - Dados subestação de Furnas.

\begin{tabular}{|c|c|c|c|c|}
\hline \multirow{2}{*}{$\begin{array}{c}\text { Dados Barramento } \\
\text { SE Furnas }\end{array}$} & \multicolumn{2}{|c|}{ Dados $345 \mathrm{kV}$} & \multicolumn{2}{c|}{ Dados $500 \mathrm{kV}$} \\
\cline { 2 - 5 } & $\begin{array}{c}\text { Dados } \\
\text { Trifásicos }\end{array}$ & $\begin{array}{c}\text { Dados } \\
\text { Monofásicos }\end{array}$ & $\begin{array}{c}\text { Dados } \\
\text { Trifásicos }\end{array}$ & $\begin{array}{c}\text { Dados } \\
\text { Monofásicos }\end{array}$ \\
\hline $\begin{array}{c}\text { Potência de curto- } \\
\text { circuito [MVA] }\end{array}$ & $14.027,3$ & $13.864,3$ & $14.027,3$ & $13.864,3$ \\
\hline $\begin{array}{c}\text { Corrente de curto- } \\
\text { circuito [kA] }\end{array}$ & 23,5 & 23,2 & 16,2 & 16,1 \\
\hline X/R & 16,6 & 15,8 & 16,6 & 15,8 \\
\hline R/X & \multicolumn{2}{|c|}{0,0602} & \multicolumn{2}{c|}{0,0602} \\
\hline X0/X1 & \multicolumn{2}{|c|}{1,0347} & \multicolumn{2}{c|}{0,0692} \\
\hline R0/X0 & \multicolumn{2}{|c|}{0,0692} & \multicolumn{2}{c|}{} \\
\hline
\end{tabular}

Fluxo de carga: Utilizando a modelagem da LT descrita anteriormente, o fluxo de carga será utilizado como ferramenta para determinar a capacidade de transmissão de potência da LT, quando submetida às diferentes técnicas de repotenciação. Para tanto, sucessivos fluxos de potência serão executados, variando-se a potência ativa e reativa da carga conectada no terminal receptor (Poços de Caldas), mantendo-se o fator de potência em 0,95. Com isso, será obtida a curva PV (Kundur, 1994), sendo que o "nariz” da curva é determinado pelo par (potência da carga, tensão no receptor) imediatamente anterior à condição de não convergência do fluxo de carga. Essas simulações devem ser feitas para todas as técnicas de repotenciação selecionadas para análise.

Durante as simulações são colhidas amostras de tensão, corrente e potência nos terminais da LT, que alimentarão as equações dos fatores de desempenho e dos IMA.

Simulações de curto-circuito: Para as simulações de curto-circuito, também será utilizado o programa DIgSILENT PowerFactory, que através de simulações de faltas ao longo da LT repotenciada pelas diversas técnicas, será possível identificar os níveis de correntes de curto-circuito atingidos nos terminais da LT.

As simulações de curto-circuito consistem em utilizar o modelamento da LT já conhecido para regime permanente, porém, alteram-se os dados do receptor (SE Poços de Caldas), retirando a carga e acoplando a base de curto-circuito referente ao barramento, 
conforme ilustra a Figura 3-4. Os dados de curto-circuito de Poços de Caldas (receptor) estão dispostos na Tabela 3-2, conforme ONS (2009).

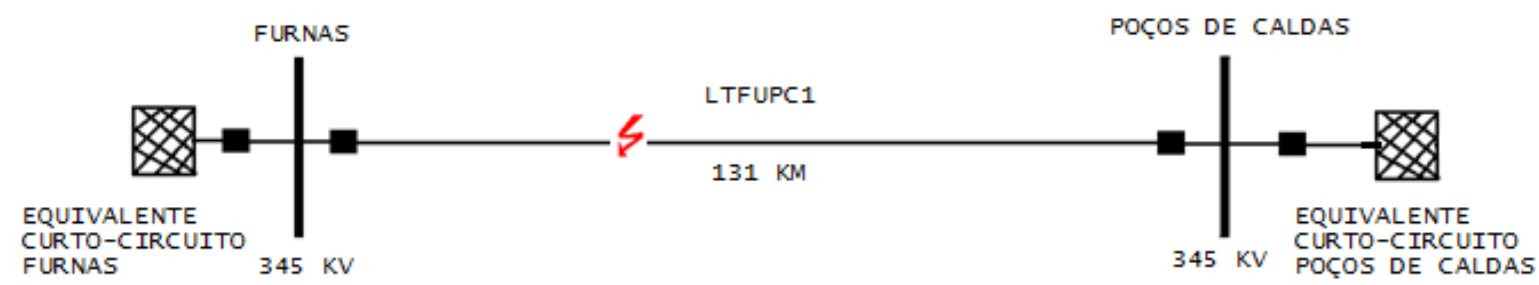

Figura 3-4 - Modelagem da LT para curto-circuitos

Depois de modelada a LT com os dois terminais dotados de suas relações de curtocircuito, aplicam-se as faltas (monofásicas e trifásicas). Serão analisados somente esses tipos de faltas, para que o estudo não se torne extensivo, já que os valores de corrente de curtocircuito dessas faltas são maiores do que as dos outros tipos de faltas, conforme Stevenson (1974). As simulações de curto-circuito permitem então, identificar as variações das correntes simétricas e tensões ao longo da LT, considerando as diferentes técnicas de repotenciação a serem avaliadas.

Tabela 3-2 - Dados subestação de Poços de Caldas

\begin{tabular}{|c|c|c|c|c|}
\hline \multirow[b]{2}{*}{$\begin{array}{l}\text { Dados Barramento } \\
\text { SE Poços de Caldas }\end{array}$} & \multicolumn{2}{|c|}{ Dados $345 \mathrm{kV}$} & \multicolumn{2}{|c|}{ Dados $500 \mathrm{kV}$} \\
\hline & $\begin{array}{c}\text { Dados } \\
\text { Trifásicos }\end{array}$ & $\begin{array}{c}\text { Dados } \\
\text { Monofásicos }\end{array}$ & $\begin{array}{c}\text { Dados } \\
\text { Trifásicos }\end{array}$ & $\begin{array}{c}\text { Dados } \\
\text { Monofásicos }\end{array}$ \\
\hline $\begin{array}{l}\text { Potência de curto- } \\
\text { circuito [MVA] }\end{array}$ & $12.728,2$ & $9.623,4$ & $8.523,6$ & $6.110,2$ \\
\hline $\begin{array}{l}\text { Corrente de curto- } \\
\text { circuito }[\mathrm{kA}]\end{array}$ & 21,3 & 16,1 & 9,84 & 7,1 \\
\hline $\mathrm{X} / \mathrm{R}$ & 12,6 & 9,5 & 19,6 & 19,6 \\
\hline $\mathrm{R} / \mathrm{X}$ & \multicolumn{2}{|c|}{0,0793} & \multicolumn{2}{|c|}{0,051} \\
\hline $\mathrm{X} 0 / \mathrm{X} 1$ & \multicolumn{2}{|c|}{1,9585} & \multicolumn{2}{|c|}{2,1802} \\
\hline R0/X0 & \multicolumn{2}{|c|}{0,1317} & \multicolumn{2}{|c|}{0,0873} \\
\hline
\end{tabular}

\subsubsection{Análise dos fatores de desempenho e índices de mérito agregado em regime permanente}

O cálculo dos fatores de desempenho e dos índices de mérito agredado (IMA), consiste na etapa em que são utilizadas as amostras colhidas nas simulações computacionais 
de regime permanente (corrente, tensão e potência). Estas amostras serão aplicadas nas devidas equações dos fatores de desempenh e IMA, que permitirão por sua vez, identificar e quantificar a eficiência no carregamento da LT, identificar as perdas na LT, identificar se houve ocorrência de limites superados nos fatores de desempenho, e ainda verificar a necessidade ou não de mudanças nos componentes da LT, para operação adequada junto às normas de transmissão de energia elétrica.

Para a análise dos fatores de desempenho e dos IMA, é importante lembrar que algumas mudanças poderão ser solicitadas na estrutura da LT em função da técnica de repotenciação a ser analisada. Estas mudanças são necessárias para que a LT opere dentro dos limites referidos nas normas regulamentadoras para transmissão de energia elétrica, conforme os requisitos mínimos para transmissão de energia elétrica (ONS, 2000). Tais mudanças podem ocorrer na estrutura da torre, espaçamento entre fases, espaçamento do feixe de condutores, altura dos condutores referente ao solo ou no comprimento da cadeia de isoladores.

A necessidade de mudanças na LT é identificada após cálculos de máxima tensão operativa e esforços mecânicos para cada técnica de repotenciação apresentada. Feitas as alterações consideradas necessárias, o cálculo de fatores de desempenho e dos IMA pode ter continuidade conforme a metodologia.

\subsubsection{Identificação da melhor técnica de repotenciação}

A identificação da melhor técnica para a repotenciação consiste em fazer a classificação dos fatores de desempenho, considerando neste item que a técnica mais eficiente seja aquela que possibilitar maior carregamento, e ainda enquadrando-se dentro dos limites operativos referidos nas normas de transmissão. Esse procedimento seletivo é comprovado consequentemente pela análise dos IMA, ou seja, a técnica que apresentar maior valor de 
índice será a mais vantajosa, pois apresentará também maior transmissão de potência na LT. Ambas as análises, devem apontar a mesma técnica de repotenciação como a mais vantajosa, caracterizando assim a eficiência da metodologia ao processar os dados coletados nas simulações de fluxo de carga.

\subsubsection{Análise de curtos-circuitos}

O estudo do desempenho de linhas de transmissão frente a curtos-circuitos será abordado nesta dissertação com intuito de observar as variações das grandezas como corrente e tensão ao longo da LT quanto esta é submetida a condições de falta. As variações podem ocorrer como afundamentos ou elevações dos valores dessas grandezas, que são características importantes para a configuração de sistemas de proteção e controle da LT em condições de faltas.

A análise de curto-circuito na LT permite a implantação de alguns fatores como:

- Ajuste dos equipamentos de manobra, transformação, medição e proteção da LT;

- Ajuste dos equipamentos acoplados aos barramentos (compensadores);

- Atualização da base de dados de curto-circuito, na rede básica;

- Cálculo de curto-circuito monofásico utilizado para proteção de reatores;

- Análise de afundamentos e/ou elevação dos valores de tensão e corrente ao longo da LT;

- Identificação de disjuntores com problemas de superação da capacidade de interrupção por corrente simétrica.

Ressalta-se que a abordagem principal para este estudo será para os dois últimos itens destacados acima, para que o estudo não se torne extensivo e fuja do objetivo principal da metodologia com foco em regime permanente. 
Segundo Esztergalyos (1992), o curto-circuito mais comum em LTs é o monofásico (fase-terra), com $70 \%$ das faltas, seguido das faltas bifásicas (fase-fase) que são em torno de $15 \%$, depois as faltas bifásicas para terra (bifásico-terra) em torno de $10 \%$ e finalmente as faltas trifásicas com ocorrência de apenas 5\%. Dentre as principais causas dos curtos-circuitos estão as seguintes:

- Defeitos mecânicos (rompimento de condutores);

- Danos nos equipamentos devido à umidade, corrosão, envelhecimento e poluição;

- Queimadas abaixo da LT;

- Descargas atmosféricas e vendavais.

As faltas serão efetuadas em três pontos da LT, ou seja, nos dois extremos e em 50\% da extensão da LT. Os tipos de faltas simuladas serão os seguintes:

- Curto-circuito trifásico;

- Curto-circuito trifásico com resistência de falta;

- Curto-circuito monofásico (Fase A/Terra);

- Curto-circuito monofásico (Fase A/Terra) com resistência de falta.

As faltas bifásicas com ou sem envolvimento da terra não serão apresentadas para não estender a dissertação com conclusões repetitivas, já que durante as simulações notou-se que os maiores valores de corrente de curto-circuito acontecem nas faltas monofásicas e trifásicas.

\subsection{FATORES DE DESEMPENHO NA REPOTENCIAÇÃO DA LT EM REGIME PERMANENTE}

Nesta seção são apresentados os fatores de desempenho a serem avaliados quando da repotenciação de uma LT. Tais fatores se restringem ao desempenho em regime permanente da linha e podem possuir níveis de prioridade diferentes, de acordo com a condição operativa 
que se busca. Ao final da dissertação, no Anexo B, está apresentado o exemplo para cálculo de cada um dos fatores. Os fatores são os seguintes:

- Rendimento;

- Regulação;

- Capacidade de condução de corrente;

- $\quad$ Limite de estabilidade de tensão - curva PV;

- Perdas na LT;

- Efeito Corona visual;

- Rádio interferência;

- Campo elétrico;

- Campo magnético.

\subsubsection{Rendimento}

O rendimento de uma linha de transmissão é definido como a relação porcentual da diferença entre a potência ativa fornecida no lado transmissor $\left(\mathrm{P}_{1}\right)$ e a potência ativa recebida no receptor $\left(\mathrm{P}_{2}\right)$, tal como mostra a equação (3.1).

$$
\eta=\left[1-\frac{\left(P_{1}-P_{2}\right)}{P_{2}}\right] .100[\%]
$$

A diferença entre as potências $\mathrm{P}_{1}$ e $\mathrm{P}_{2}$ representa as perdas na linha durante a transmissão de energia elétrica. Essas perdas são compostas pelas perdas por efeito Joule nos condutores, perdas no dielétrico entre os condutores, perdas causadas por histerese e correntes parasitas de Foucault na alma de aço dos condutores e perdas devido à circulação de corrente nos cabos para-raios. Dentre estas, as perdas por efeito Joule são as mais significantes segundo Fuchs (1982). Isso posto, o método utilizado neste trabalho para avaliar o rendimento da linha de transmissão repotenciada, considerará apenas perdas por efeito Joule. As perdas no dielétrico entre os condutores serão abordadas posteriormente, no item referente a perdas 
por efeito Corona. A fim de avaliar o rendimento da linha repotenciada para diferentes níveis de carregamento, os procedimentos utilizados foram os seguintes:

- Considera-se a linha de transmissão alimentada por um barramento infinito;

- Na outra extremidade da linha, conecta-se uma carga estática trifásica composta das partes ativa e reativa;

- Utilizando-se de um programa de cálculo de fluxo de potência trifásico, variam-se as potências ativa e reativa da carga de 0 (zero) até um valor em que o método de cálculo do fluxo de carga deixa de convergir, mantendo constante o fator de potência da carga. Com isso, será obtido o máximo carregamento em regime permanente da linha de transmissão. Neste trabalho, o fluxo de potência trifásico foi executado com o auxílio do programa DIgSILENT PowerFactory (DIgSILENT, 2010);

- Para cada nível de carregamento simulado, aplica-se a expressão (3.1) para calcular o rendimento da LT.

Com a aplicação do procedimento descrito anteriormente, será possível obter curvas que descrevem como o rendimento varia com o carregamento da linha de transmissão. Posteriormente, essas curvas, juntamente com outras que serão explicadas nas seções seguintes, serão empregadas para determinar índices de desempenho das linhas de transmissão operando em regime permanente.

\subsubsection{Regulação de tensão}

A regulação de tensão em uma LT pode ser definida como a variação da tensão entre os terminais do transmissor e receptor para um dado nível de carga, tomada como porcentagem da tensão no receptor (ou nos terminais da carga), segundo Fuchs (1977). Essa definição está apresentada por meio da equação (3.2). 


$$
R E G=\frac{V_{1}-V_{2}}{V_{2}} \cdot 100[\%]
$$

sendo,

$R E G=$ regulação da $\mathrm{LT}$, em $\%$.

$V_{l}=$ módulo da tensão eficaz no terminal transmissor, em V.

$V_{2}=$ módulo da tensão eficaz no terminal receptor ou da carga, em V.

Nesta dissertação, serão obtidas curvas que relacionarão a regulação com a variação da carga na linha. Os procedimentos para a obtenção dessas curvas são os mesmos apresentados na seção anterior para a obtenção das curvas de rendimento.

\subsubsection{Capacidade de condução de corrente}

Um dos mais importantes fatores limitantes para a máxima potência a ser transmitida por uma linha de transmissão é sua capacidade de condução de corrente, a qual está relacionada à temperatura em que está submetida a LT. Neste contexto, podem ser identificados dois limites, a depender das condições de operação (Furnas, 2009):

- Limite de carregamento normal: é o limite de carregamento contínuo da LT, normalmente referenciado a uma temperatura de operação de $50{ }^{\circ} \mathrm{C}$;

- Limite de carregamento de emergência: é o máximo valor de carregamento da LT em condições de emergência, por até 4 horas, acima do seu limite de carregamento normal. Normalmente está associado à temperatura de $80{ }^{\circ} \mathrm{C}$.

\subsubsection{Limite de estabilidade de tensão (Curvas PV)}

Com o crescimento da demanda de carga no sistema elétrico e dificuldades para investimento em melhorias ou ampliações, os componentes do sistema elétrico ficam sujeitos a operarem em condições próximas de seus limites, o que pode acarretar fenômenos indesejáveis na estabilidade do sistema elétrico de potência. Neste contexto, o estudo de 
estabilidade de tensão permite determinar o quanto um estado de operação de uma LT é estável, para que não ocorra um colapso de tensão, levando a uma sequência de eventos com desligamentos ou prejuízos aos equipamentos do sistema (Kundur, 1994).

Para representar o limite de estabilidade de tensão em uma LT, a construção de curvas PV foi a alternativa utilizada. Além disso, essas curvas são de grande valia para determinar o máximo carregamento que pode ser aplicado a uma LT sem que os limites de tensão de regime permanente previstos na resolução ANEEL n ${ }^{0} 505$ (ANEEL, 2001) sejam violados.

\subsubsection{Perdas na LT}

Neste trabalho serão apresentadas as perdas por efeito Joule e perdas por efeito Corona na LT, conforme recomendado em ONS (2000). Assim, em uma análise comparativa entre diversas técnicas de repotenciação, esses fatores podem servir como um importante subsídio na tomada de decisão para a seleção da técnica a ser empregada.

As perdas por efeito Joule serão determinadas diretamente pela execução do programa de fluxo de potência mencionado anteriormente. Já as perdas por efeito Corona serão estimadas conforme procedimentos apresentados em Fuchs (1979) e resumidos a seguir.

Para o cálculo de perdas de potência na LT devido ao efeito Corona, considerando tempo bom (sem chuva), pode-se empregar a fórmula de Peterson, conforme apresentado em Fuchs (1979). A equação (3.3) representa a fórmula de Peterson.

$$
P T B=\frac{\left(0,00002094 \cdot f \cdot U^{2} \cdot \phi\right)}{\left(\log \left[\frac{D m}{r}\right]\right)^{2}} \quad[k W / k m]
$$

Sendo:

$f[H z]=$ frequência do sistema;

$U[k V]=$ tensão eficaz entre fase e neutro; 
$r[\mathrm{~cm}]=$ raio do condutor;

$D m[\mathrm{~cm}]=$ distância média geométrica entre fases;

$\phi=$ fator experimental que depende da relação:

$$
\phi=\frac{E}{E c r v}
$$

Em que:

$E[\mathrm{kV} / \mathrm{cm}]=$ gradiente de potencial do condutor ou campo elétrico superficial do condutor;

Ecrv $[\mathrm{kV} / \mathrm{cm}]=$ gradiente crítico visual do condutor;

O cálculo de $E$, é apresentado no anexo B, no tópico B.1.5.

O cálculo de Ecrv segue conforme a equação (3.5).

$$
E c r v=18,11 \cdot\left(1+\frac{0,54187}{\sqrt{r}}\right)[\mathrm{kV} / \mathrm{cm}]
$$

Para o cálculo de perdas por efeito Corona sob chuva, adotou-se o método desenvolvido pelos engenheiros Gary e Cladé, da companhia Eletricité de France (EDF), apresentado em Fuchs (1979). Este procedimento, apesar de antigo, ainda é base para os programas computacionais atuais que simulam as perdas Corona sob chuva, conforme apresentado em Giudice (2001).

$$
P=K \cdot P n \quad[W / m]
$$

Sendo:

$\mathrm{P}=$ perdas corona sob chuva

$K=$ coeficiente de perdas definido por:

$$
K=\frac{f}{50} \cdot(n \cdot r \cdot \beta)^{2} \cdot \frac{\log \left[\left(\frac{R}{R c}\right) \cdot \log \left(\frac{\rho}{R c}\right)\right]}{\log \left(\frac{R}{\rho}\right)}
$$


Na qual:

$f[H z]=$ frequência do sistema;

$r[\mathrm{~cm}]=$ raio dos condutores;

$$
\beta=1+\frac{0,3}{\sqrt{r}}
$$

$R c[\mathrm{~cm}]=$ raio do condutor, (equivalente a um condutor múltiplo);

$$
\rho[c m]=18 \cdot \sqrt{((n \cdot r)+4)}
$$

$n=$ número de subcondutores na fase;

$R=$ raio de um cilindro coaxial com o condutor e de potencial nulo, sendo:

$$
R=\frac{R c \cdot \operatorname{anti} \log \left(0,02412 \cdot 10^{-6}\right)}{C s} \quad[\mathrm{~cm}]
$$

Cs = capacitância de sequência positiva da LT.

Para a determinação do valor de $P n$, será necessária a utilização da Erro! Fonte de referência não encontrada. e da Erro! Fonte de referência não encontrada..

A Erro! Fonte de referência não encontrada. ilustra o valor do coefieciente "m" (eixo das ordenadas), que se refere ao estado físico do condutor, e o eixo das abscissas que se refere ao índice de precipitação de chuvas (considerando $10 \mathrm{~mm} / \mathrm{h}$ nas simulações). De acordo com Fuchs (1979), para as técnicas de lançamentos de mais cabos no feixe ou para configuração original da LT (configurações 1, 2, 3, 5, 6, 7) utilizou-se nas simulações o coeficiente "m" no valor de 0,6 (refere-se a cabos usados). Para as técnicas de recondutoramento, ou seja com troca de todos os cabos, (configurações 4 e 8 ) considerou-se “m” igual a 0,75 (refere-se a cabos novos). 


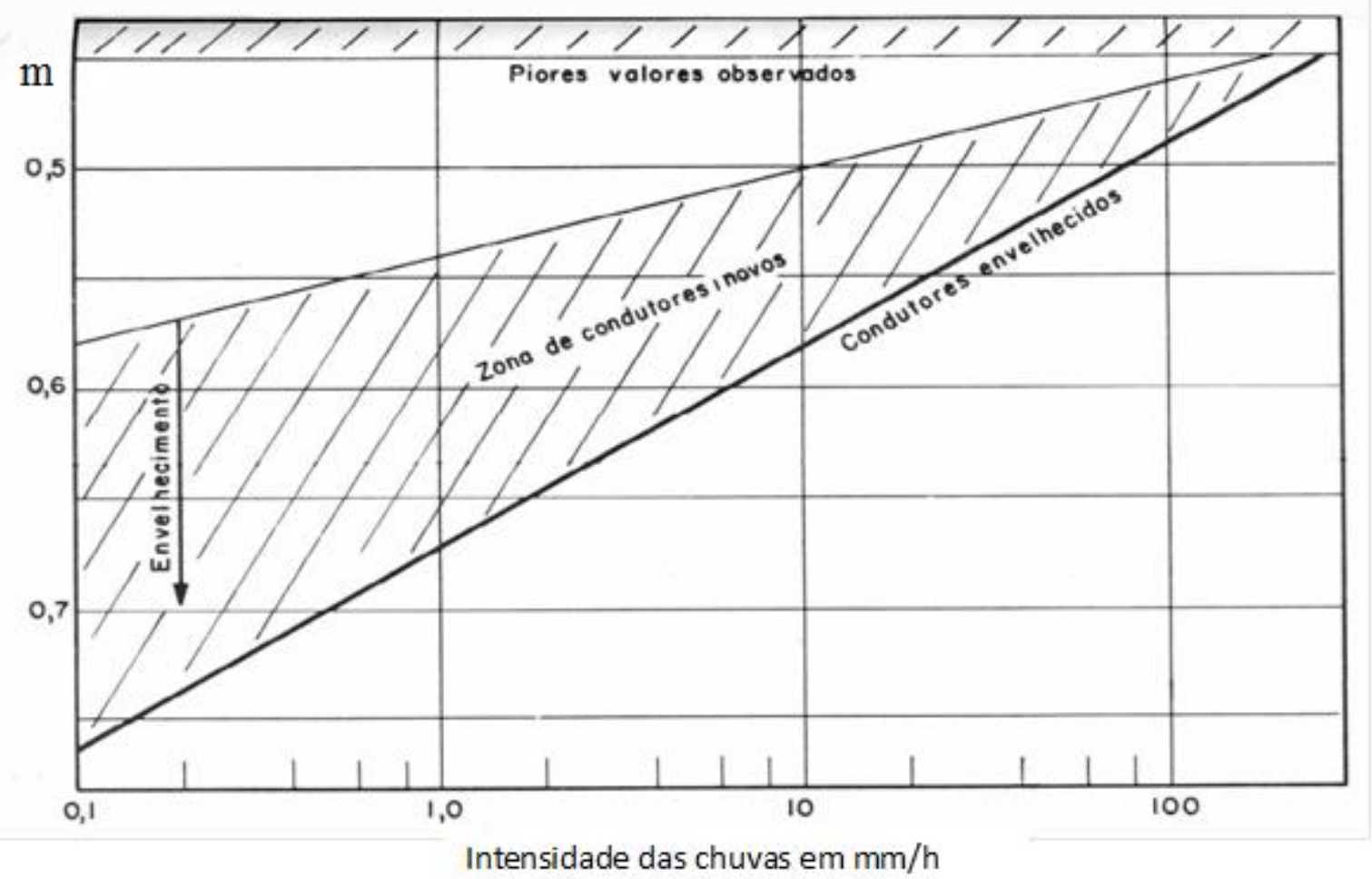

Figura 3-5 - Coeficiente de estado da superfície dos condutores “m”. (Fonte: Fuchs, (1977))

Feita a relação da Erro! Fonte de referência não encontrada., e de posse do valor de “m”, encontra-se o índice $P n$ utilizando a Erro! Fonte de referência não encontrada., que relaciona o coeficiente " $\mathrm{m}$ " com o gradiente relativo E/Ecrv do condutor. Ressalta-se que E será calculado pelo programa Campo, e Ecrv defini-se conforme a equação (3.5), já apresentada. 


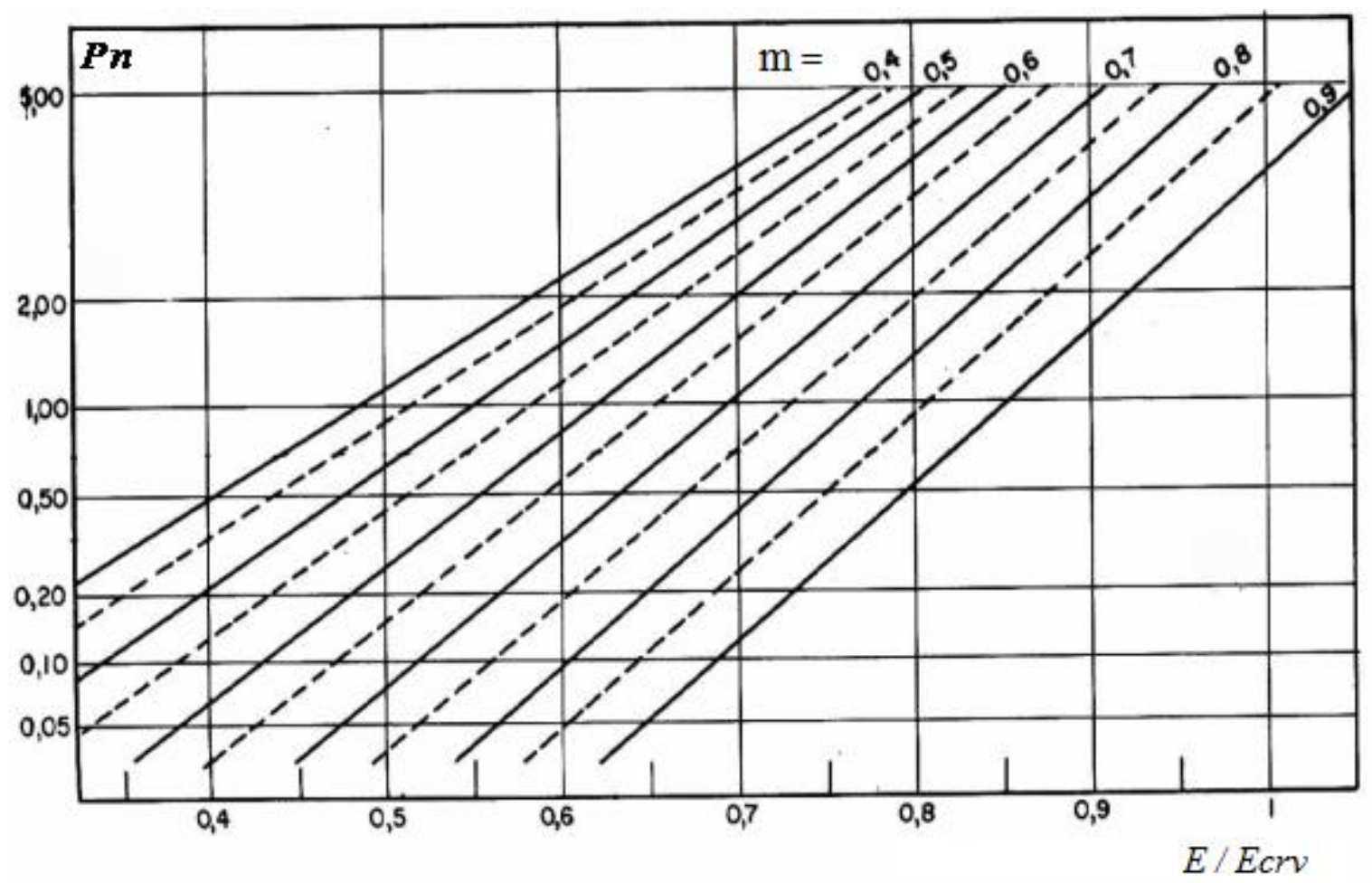

Figura 3-6 - Índice Pn (perdas reduzidas sob chuva) (Fonte: Fuchs, (1977))

\subsubsection{Corona visual}

Segundo ONS (2000), uma linha de transmissão, incluindo cabos, ferragens das cadeias de isoladores, e os acessórios dos cabos, não deve apresentar corona visual $90 \%$ do tempo, para as condições atmosféricas predominantes na região atravessada pela linha de transmissão.

O fenômeno óptico do efeito Corona ou corona visual acontece quando $E>$ Ecrv, sendo $E$ o campo elétrico na superfície do condutor e Ecrv o gradiente crítico visual do condutor, que varia com a atmosfera, temperatura, pressão barométrica em que a linha esta submetida.

De acordo com Fuchs (1979), a equação (3.5) apresentada anteriormente é a mais conveniente para estimar o valor de Ecrv.

$$
E c r v=18,11 \cdot\left(1+\frac{0,54187}{\sqrt{r}}\right)[k V / c m]
$$


O cálculo de " $E$ " será determinado com auxílio do programa "CAMPO" conforme o Anexo B, no tópico B.1.5.

\subsubsection{Rádio interferência}

Segundo ONS (2000), a relação sinal/ruído no limite da faixa de servidão, para a tensão máxima operativa, deve ser, no mínimo, igual a $24 \mathrm{~dB}$, para $50 \%$ do período de um ano. A relação adotada para o cálculo deverá ser o nível mínimo de sinal na região atravessada pela linha de transmissão, conforme (ONS, 2000). Assim, a metodologia proposta inclui também analisar a rádio interferência causada pela linha de transmissão, quando repotenciada segundo diferentes técnicas. A equação (3.11) foi adotada para cálculo de RI (rádio interferência), segundo Fuchs (1979), e o programa "CAMPO” (Campo, 2004), foi utilizado para o cálculo de "E”, conforme anexo B.

$$
R I=58,7+K \cdot(E-16,95)+40 \cdot \log \cdot(d / 3,93)+10 \cdot \log \cdot(n / 4)+32 \cdot \log \cdot(20 / D)
$$

$$
\begin{aligned}
& K=3 \text { para } 500 \mathrm{kV} \text { e } 3,5 \text { para } 345 \mathrm{kV} \\
& D=\text { distância do condutor central até o ponto de medição } \\
& E=\text { campo elétrico superficial do condutor } \\
& d=\text { diâmetro do condutor } \\
& n=\text { número de condutores }
\end{aligned}
$$

\subsubsection{Campo elétrico}

O campo elétrico a um metro do solo no limite da faixa de servidão deve ser inferior ou igual a 4,2 kV/m conforme ONS (2000), com o objetivo de assegurar que não provoque efeitos nocivos a seres humanos. O cálculo do campo elétrico será efetuado pelo programa “CAMPEM" (Campem, 2004), semelhante aos procedimentos adotados em, Pinto et al (2005), para todas as configurações de repotenciação aplicadas neste projeto. A Figura 3-7 
ilustra o ponto de medição fixado no limite da faixa de servidão da LT, ou seja, a 30 metros da fase central da LT. O método de cálculo do campo elétrico é apresentado no anexo B.

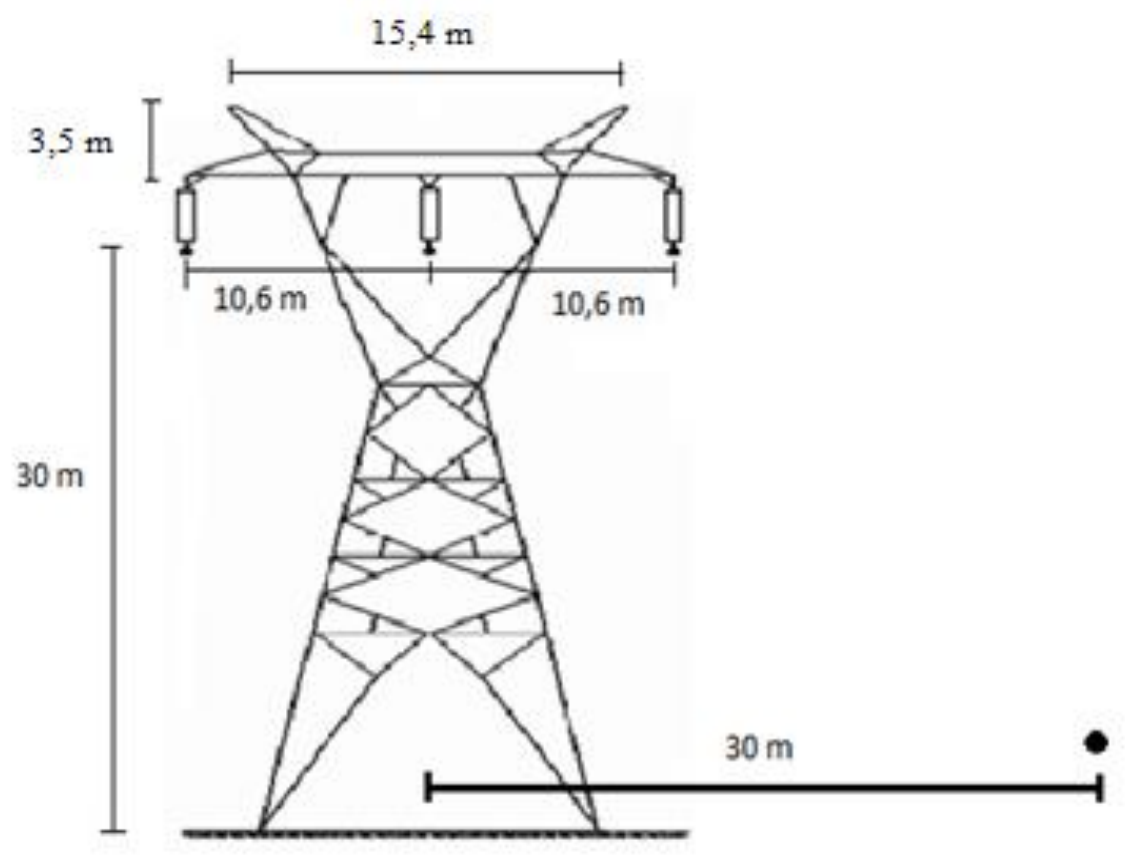

Figura 3-7- Ponto de medição do campo elétrico

\subsubsection{Campo magnético}

O campo magnético na condição de carregamento máximo e no limite da faixa de servidão deve ser inferior ou igual a $67 \mathrm{~A} / \mathrm{m}$, equivalente à indução magnética de $833 \mathrm{mG}$ conforme ONS (2000). Deve-se assegurar que o campo no interior da faixa de servidão, em função da utilização de cada trecho da mesma, não provoque efeitos nocivos a seres humanos. O campo magnético será calculado conforme o programa “CAMPEM” (Campem, 2004), para todas as configurações de repotenciação aplicadas neste projeto. Assim como no campo elétrico, a Figura 3-7 ilustra que o ponto de medição do campo magnético deve estar a 30 metros da fase central. A utilização do programa CAMPEM, é apresentada no Anexo B. 


\section{3 ÍNDICES DE MÉRITO AGREGADO AVALIADOS NA REPOTENCIAÇÃO EM REGIME PERMANENTE}

Os fatores de desempenho apresentados anteriormente contribuem para a identificação da técnica mais vantajosa para execução de uma repotenciação eficiente. No entanto, não se pode definir um índice único que represente as principais influências de cada um desses fatores.

Os fatores de desempenho tratados anteriormente vinculam a operação da LT de acordo com as normas regulamentadoras já citadas, no entanto, existem situações em que se deseja a identificação da técnica de repotenciação mais eficiente, apenas em termos de máxima potência transmitida, sem as implicações dos fatores menos.

A situação apresentada conduz a ideia de descarte de alguns fatores, que podem ser analisados em segundo plano, como: campo elétrico, campo magnético, perdas corona e rádio interferência. Dessa forma novos índices numéricos são propostos. Ressalta-se que os novos índices devem identificar como a melhor técnica de repotenciação, a mesma selecionada pelos fatores de desempenho.

Os novos índices são chamados de índices de mérito agregado (IMA), pois buscam estabelecer uma relação entre os fatores de desempenho que mais influenciam na transmissão de potência em uma LT.

Os fatores de desempenho mais influentes como o rendimento, regulação e estabilidade de tensão em regime permanente, serão relacionados entre si, buscando a máxima transmissão de potência na LT, definindo de forma mais robusta a melhor técnica de repotenciação aplicável na LT.

Os IMA, são definidos em quatro possibilidades de aglutinação, sendo eles:

- Índice de máximo carregamento;

- Índice de máximo carregamento restrito por tensão; 
- Índice de máximo rendimento restrito por tensão;

- Índice de máxima regulação restrito por tensão;

Para o cálculo dos índices de mérito agregado, são utilizadas as mesmas amostras do cálculo dos fatores de desempenho (tensão, corrente e potência da LT), registradas nas simulações computacionais. Estas amostras, lançadas nas devidas equações, permitem quantificar as variações de carregamento da LT, submetidas aos limites operativos de rendimento, regulação de tensão e estabilidade de tensão, conforme ONS (2000) e Aneel (2001). Os dois últimos limites citados são referentes aos níveis de tensão da LT, caracterizados como os mais influentes no carregamento da LT, e por isso serão utilizados como referência no cálculo dos índices de mérito agregado. Esta afirmação poderá ser comprovada no quarto capítulo, conforme os resultados da aplicação da metodologia.

A identificação da melhor técnica para a repotenciação da LT conforme os IMA, consiste em, fazer a classificação destes, considerando a técnica mais eficiente como aquela que apresentar valores mais elevados para os índices.

Esta seleção será apresentada através de uma tabela informando os IMA de cada configuração de repotenciação proposta, permitindo a identificação dos índices mais eficientes.

Os IMA proporcionam ainda, a identificação das situações de carregamento em que a LT necessita de compensadores de potência reativa, para manter os valores de tensão nos níveis regulamentados. Essa observação é notória quando os índices possuem valores negativos, conforme poderá ser observado nos resultados apresentados mais adiante.

Na sequência, serão apresentadas as equações de cada IMA proposto, ressalta-se ainda, que, no Anexo B serão apresentados exemplos de cálculo para cada IMA. 


\subsection{1 Índice de Máximo Carregamento (i $\left.\mathbf{i}_{\mathrm{MAXC}}\right)$}

Este índice será empregado para avaliar o máximo carregamento da LT, indicando o montante máximo de potência ativa a ser transmitido sem que haja colapso de tensão. $\mathrm{Na}$ presente metodologia, esse índice pode ser calculado pela equação (3.12).

$$
i_{M A X C}=\frac{P_{M A X}-P_{N}}{\sqrt{3} \cdot V_{N} \cdot I_{N}}
$$

sendo:

$P_{M A X}=$ a potência ativa máxima obtida com o auxílio da curva PV (ver Figura 3-8);

$P_{N=}$ a potência ativa transmitida pela linha em condições normais de operação (potência base);

$V_{N=}$ a tensão nominal de linha (valor eficaz);

$I_{N=}$ a corrente referente à operação normal da linha a $50^{\circ} \mathrm{C},(1.218 \mathrm{~A})$.

Para cada valor de potência transmitida no terminal receptor, tem-se um valor relativo tensão também no receptor, assim com o auxilio da curva PV podemos observar as características do índice proposto.

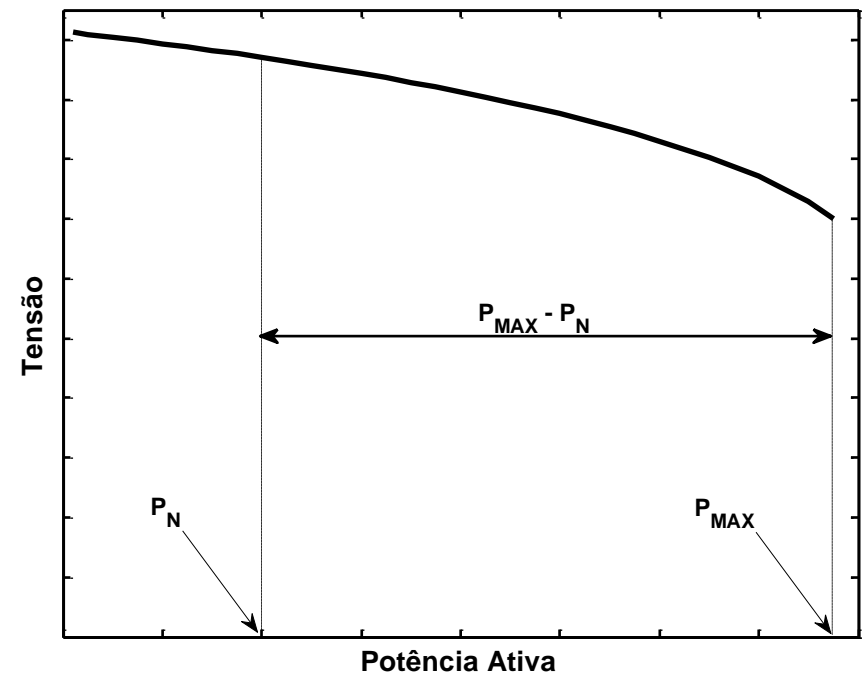

Figura 3-8 - Cálculo do índice $i_{\text {MAXC }}$ usando a curva PV. 


\subsection{2 Índice de Máximo Carregamento restrito por tensão (i $\left.\mathbf{i}_{\text {MAXC_v }}\right)$}

Semelhante ao índice definido anteriormente, este utiliza a curva PV e indica o máximo carregamento que a linha de transmissão suporta sem violar o limite inferior de tensão aceitável, segundo recomendações da Resolução ANEEL número 505 (ANEEL, 2001). Este valor é igual a 0,95 pu. A expressão (3.13) define o cálculo desse índice:

$$
i_{M A X C_{-} V}=\frac{P_{M A X V}-P_{N}}{\sqrt{3} \cdot V_{N} \cdot I_{N}}
$$

sendo $P_{M A X_{-} V}$ o valor de potência ativa tomado quando a tensão for igual a 0,95 pu. Esta grandeza está demonstrada na Figura 3-9.

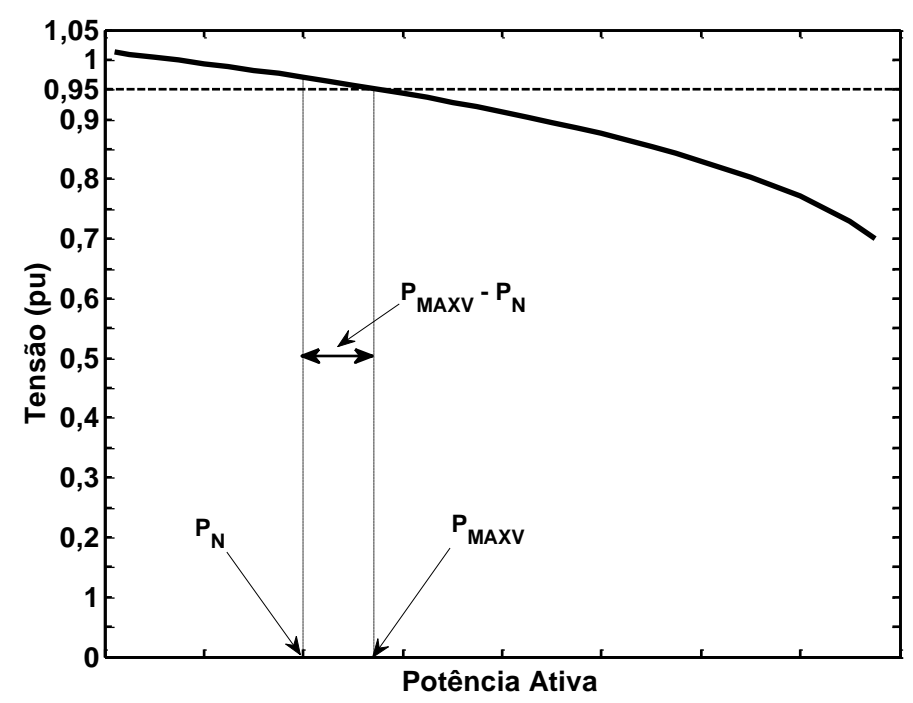

Figura 3-9 - Cálculo do índice $i_{M A X C_{-} V}$ usando a curva PV.

\subsection{3 Índice de Máximo Rendimento restrito por tensão (i $\left.\mathbf{i}_{\mathrm{MAX}_{\eta_{-}} \mathrm{V}}\right)$}

Este índice possui caráter mais qualitativo em relação aos apresentados anteriormente e indica qual o rendimento máximo da LT quando a mesma transportar potência ativa igual a $P_{M A X_{-} V}$, definida anteriormente. É obtido diretamente da curva que relaciona o rendimento com a variação da potência ativa transmitida. Para efeito de 
comparação com outras técnicas de repotenciação, seu valor pode ser calculado usando a expressão (3.14).

$$
i_{M A X \eta_{-} V}=\frac{\eta_{M A X_{-} V}}{100} \cdot \frac{P_{M A X V}}{\sqrt{3} \cdot V_{N} \cdot I_{N}}
$$

sendo $\eta_{M A X_{-} V}$ o rendimento $\left(\right.$ em $\%$ ) correspondente à potência $P_{M A X V}$. As demais grandezas de (3.14) foram definidas anteriormente. Nota-se que quanto maior o valor deste índice, melhor o desempenho da LT.

\subsection{4 Índice de Máxima Regulação restrito por tensão (i $\mathbf{i}_{\text {MAXR_V }}$ )}

De maneira semelhante ao índice $i_{M A X \eta_{-} V}$, este índice visa comparar diferentes técnicas de repotenciação em relação aos seus impactos na regulação de tensão da LT, considerando o valor de $P_{M A X_{-} V}$. Neste caso, a expressão (3.15) é capaz de representar o índice $i_{M A X R_{-} V}$ adequadamente.

$$
i_{\text {MAXR }-V}=\frac{100}{R_{M A X_{-} V}} \cdot \frac{P_{M A X V}}{\sqrt{3} \cdot V_{N} \cdot I_{N}}
$$

sendo $R_{M A X_{-} V}$ o valor de regulação de tensão correspondente a $P_{M A X V}$. Quanto maior o valor de $i_{M A X R_{-} V}$, melhor é o desempenho da LT. 


\section{Capítulo 4}

\section{Aplicação da Metodologia}

Neste capítulo a utilidade da metodologia de análise proposta é demonstrada tomando como objeto de estudo, uma linha de transmissão pertencente ao sistema da Eletrobrás Furnas. Em seguida são apresentadas as alternativas de repotenciação consideradas neste trabalho, os resultados das simulações realizadas, as análises dos mesmos com posterior classificação daquelas alternativas quanto às vantagens técnicas da repotenciação.

\subsection{ESCOLHA DA LINHA PARA REPOTENCIAÇÃO E COMPOSIÇÃO DO BANCO DE DADOS}

Seguindo o primeiro passo da metodologia proposta apresentada no capítulo anterior, deve-se fazer uma análise para identificar a viabilidade de colocar uma LT disponível para repotenciação. Naturalmente, as LTs no limite de sua capacidade de transmissão de energia elétrica são as mais indicadas para serem repotenciadas, porém nada impede que a repotenciação seja feita em uma linha ainda com folga na transmissão, pois futuramente, pensando em planejamento estratégico, esta poderá contribuir na expansão do sistema elétrico envolvido. Neste trabalho, as análises serão conduzidas em uma LT de 345 kV (LTFUPC1Linha de Transmissão Furnas Poços de Caldas) que interliga as subestações da Usina de Furnas e de Poços de Caldas, com $131 \mathrm{~km}$ de comprimento, circuito simples, feixe de 2 condutores por fase (condutores tipo Drake 795), distância de 30 metros entre condutores e 
solo, uma faixa de servidão de 60 metros, torres tipo A51 e A31 conforme Furnas (2000) e cadeia de isoladores de suspensão simples. Os cabos para-raios são de bitola 3/8 de polegadas EHS - tipo ACO-07, e não serão modificados após a aplicação das metodologias de repotenciação, pois este tipo de cabo é comumente utilizado em linhas de transmissão e sua substituição não alavancaria ganhos significativos de potência na LT, sobretudo nas técnicas utilizadas na metodologia em propósito. Os dados completos da LT em estudo são apresentados no Anexo A. Ressalta-se que fatores como a localização geográfica da LT, a tensão de 500 kV já existente na estação de Poços de Caldas, e a folga dos fatores limitantes (espaçamento entre cabos, folgas para suporte de pesos, número de cabos, limites de corrente e temperatura), contribuíram para a escolha desta LT. A localização geográfica da LT também contribui para o melhor escoamento da potência ganha na repotenciação, devido à proximidade de grandes centros industriais e interligações do sistema elétrico. A elevação da tensão para $500 \mathrm{kV}$ poderá ser facilmente operada pela existência desta tensão na estação de Poços de Caldas, minimizando gastos na interligação de barramentos e na adição de transformadores para elevação da tensão na subestação da Usina de Furnas.

Para compor o banco dos dados necessários para as diferentes simulações, os parâmetros apresentados no Anexo A foram empregados. A Figura 4-1 ilustra a torre da LT, com seus componentes e distâncias geométricas. 


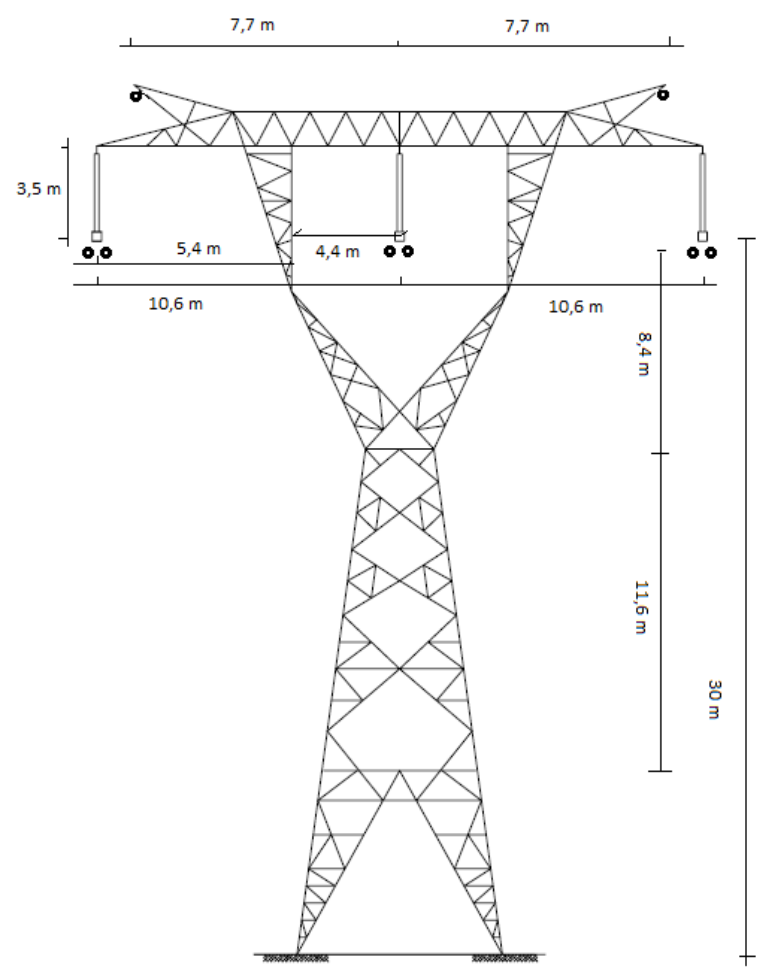

Figura 4-1 - Torre típica da LTFUPC1

\subsection{SELEÇÃO DA TÉCNICA DE REPOTENCIAÇÃO}

Nesta seção, apresentam-se as técnicas a serem avaliadas para a LT em estudo. A escolha das mesmas se baseou nas características mecânicas e de isolação atuais da LT escolhida para estudo. Ressalta-se que dependendo da técnica de repotenciação analisada, os parâmetros da linha de transmissão podem sofrer pequenas alterações. Como exemplo, cita-se a elevação da classe de tensão operativa da LT, em que deve ser alterado o tamanho das cadeias de isoladores com a consequente alteração das distâncias entre condutor e solo. Portanto, antes de se proceder aos cálculos, deve-se avaliar se as adaptações a serem realizadas na LT a ser repotenciada são técnica e economicamente viáveis, e se enquadram nos requisitos mínimos para transmissão, que são apresentados no Anexo C.

A configuração original da LT será denominada "Configuração 1". As técnicas de repotenciação avaliadas são:

- Configuração 2: três condutores por fase do tipo Drake 795, $345 \mathrm{kV}$; 
- Configuração 3: quatro condutores por fase do tipo Drake 795, 345 kV ;

- Configuração 4: três condutores por fase do tipo Rail 954, $345 \mathrm{kV}$;

- Configuração 5: dois condutores por fase do tipo Drake 795, 500 kV;

- Configuração 6: três condutores por fase do tipo Drake 795, $500 \mathrm{kV}$;

- Configuração 7: quatro condutores por fase do tipo Drake 795, 500 kV;

- Configuração 8: três condutores por fase do tipo Rail 954, $500 \mathrm{kV}$.

A Figura 4-2 ilustra as disposições dos condutores correspondentes às técnicas de repotenciação analisadas. Ressalta-se que para os casos de elevação da tensão operativa de $345 \mathrm{kV}$ para $500 \mathrm{kV}$ (configurações de 5 a 8) não foi necessário alterar os espaçamentos horizontais entre os mesmos, porque a LT analisada tem a particularidade de atender às distâncias mínimas de segurança para 500 kV. 


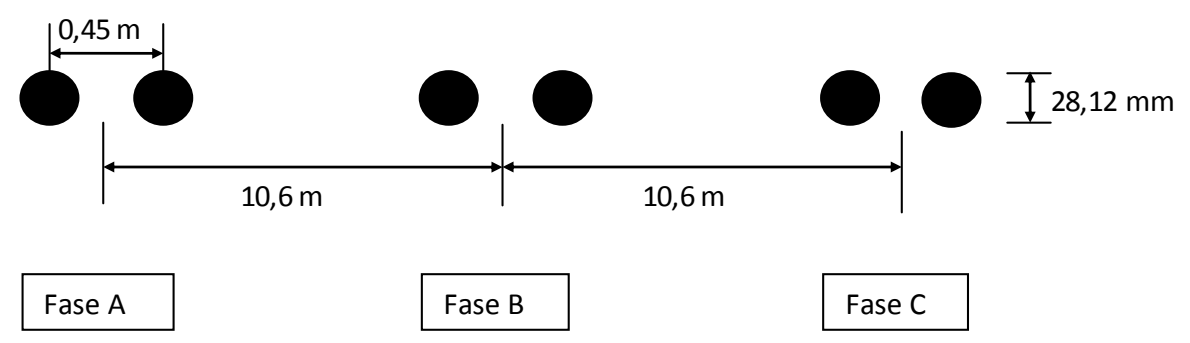

(a) Configuração 1 e Configuração 5.

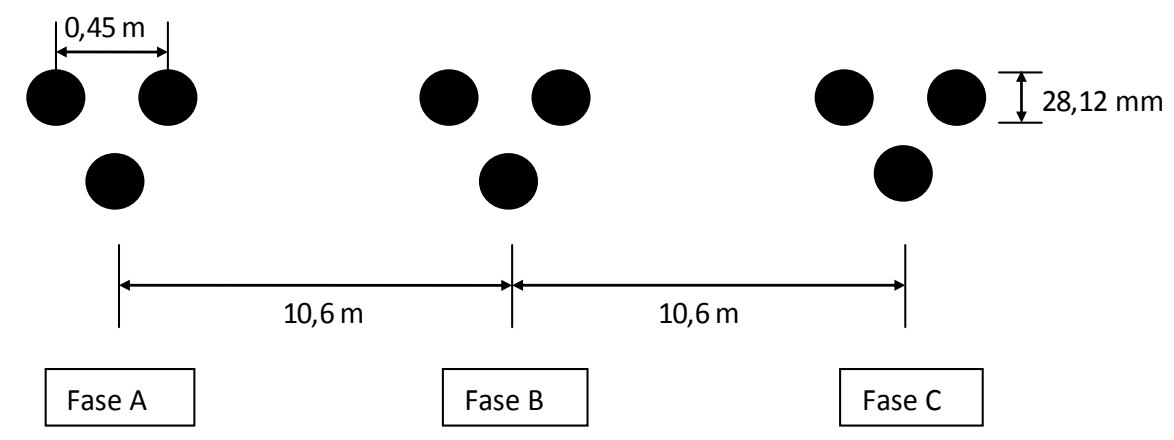

(b) Configuração 2 e Configuração 6.

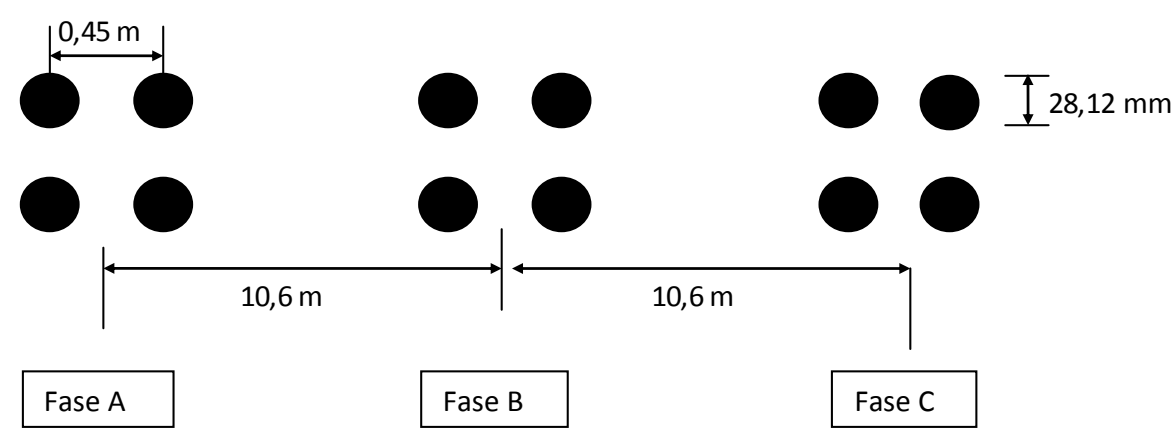

(c) Configuração 3 e Configuração 7.

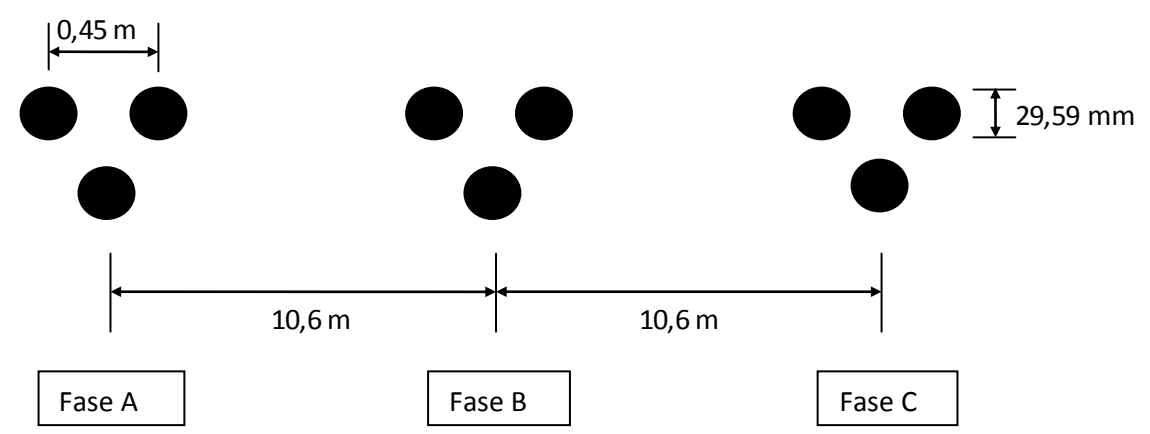

(d) Configuração 4 e Configuração 8.

Figura 4-2 - Configurações dos condutores empregados nas técnicas de repotenciação. 
O critério de escolha dos condutores de maior bitola tipo Rail 954 MCM, característico das configurações 4 e 8 e o espaçamento entre os subcondutores de 0,45 metros nos procedimentos das técnicas, foram devido à maioria dos sistemas de $500 \mathrm{kV}$ de Furnas adotarem estas características. Assim pode-se dar destaque a um dos propósitos fundamentais da análise da repotenciação, que é a busca de elevado desempenho da LT em sua capacidade de transmissão, modificando ao mínimo os equipamentos e reaproveitando tecnologias bem conceituadas e aplicadas pelo proprietário da LT.

\subsection{SIMULAÇOES COMPUTACIONAIS}

Neste tópico serão descritos alguns procedimentos para modelamento da LT no PowerFactory, conforme as configurações de repotenciação propostas. No Anexo B, serão apresentados exemplos da utilização das amostras colhidas nas simulações computacionais, para melhor entendimento da metodologia.

Modelamento da LT: A Figura 4-3 ilustra a LTFUPC1 modelada no DIgSILENT PowerFactory, com seus barramentos, traçado, fontes, disjuntores, medidores e cargas acopladas. 


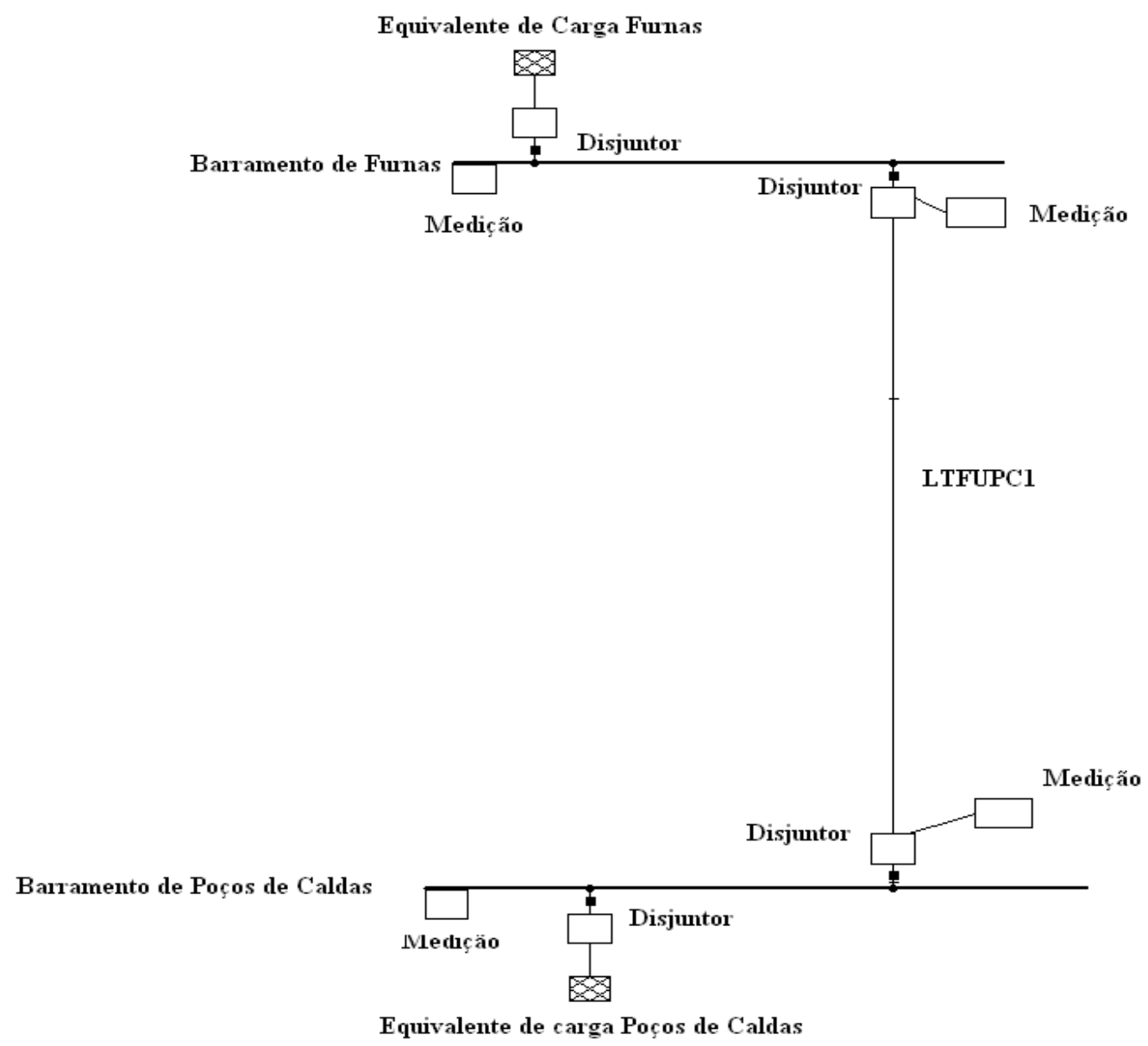

Figura 4-3 - Sistema elétrico analisado representando a LT

A Figura 4-4, apresenta a janela de entrada de dados do programa, a qual permite inserir informações sobre a configuração geométrica e elétrica da LT em estudo, como bitola dos cabos condutores, número de condutores, espaçamento entre condutores, tipo de condutores, tipo de para-raios, resistividade da LT, tensão nominal, frequência nominal, extensão da LT, dentre outros. As configurações geométricas da LT são alteradas conforme a técnica escolhida para simulação. 


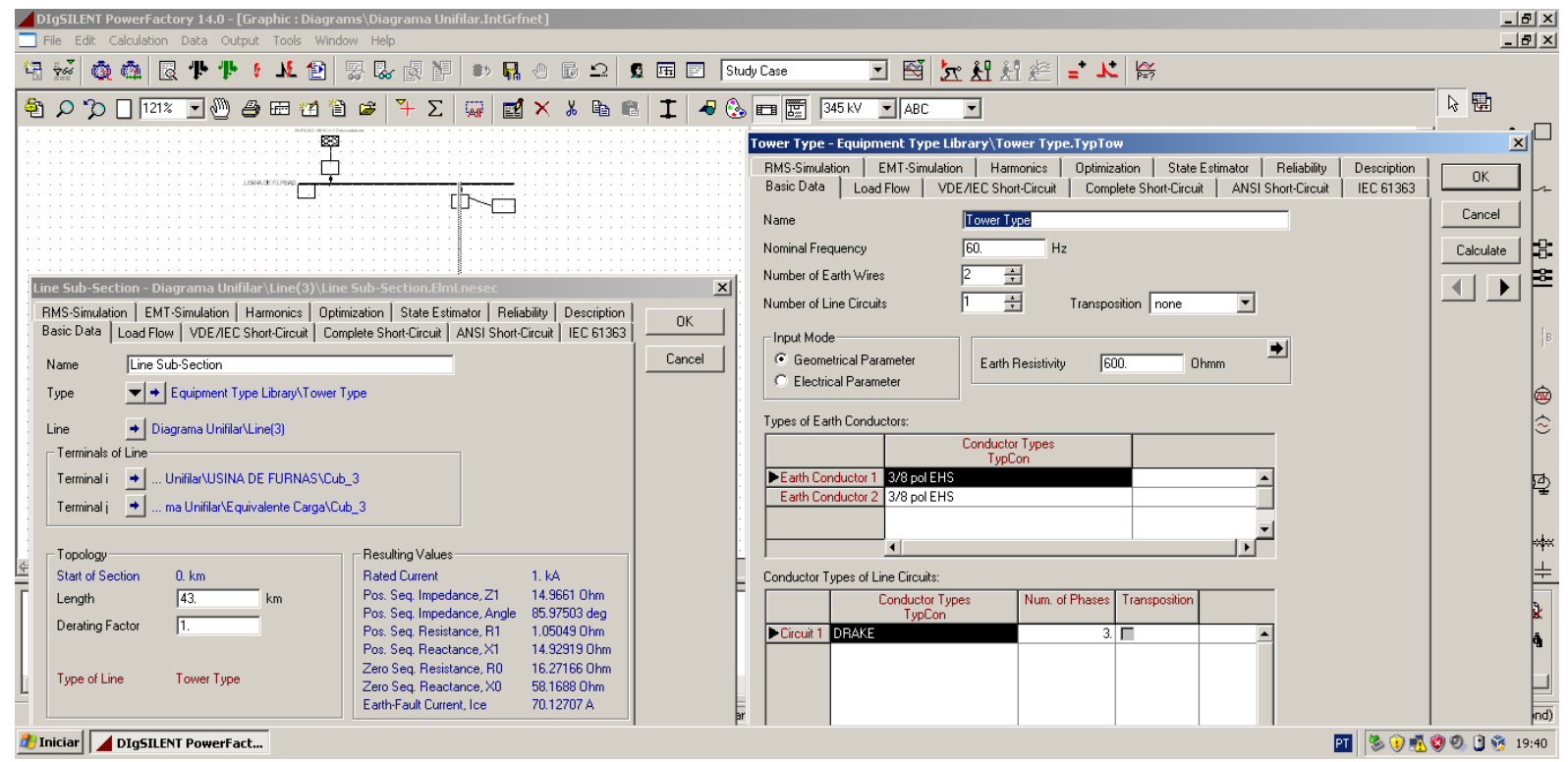

Figura 4-4 - Modelamento geométrico e elétrico da LT

Fluxo de carga: a Figura 4-5 ilustra uma janela de entrada de dados das cargas acopladas no barramento receptor, e também algumas amostras de tensão e corrente que serão colhidas nos medidores, já que a figura apresenta o diagrama unifilar da LT, com a execução da simulação de fluxo de carga. As amostras servirão como dados que serão utilizados no cálculo dos fatores de desempenho e dos IMA. Por meio do Anexo B pode-se verificar a utilização desses dados.
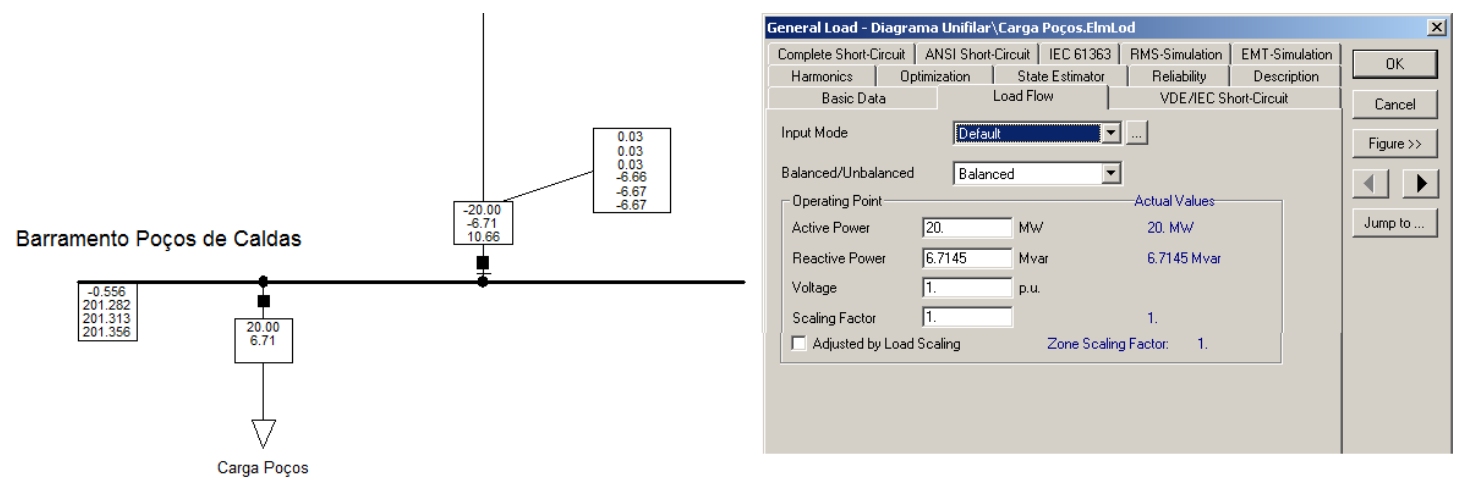

Figura 4-5 - Simulação de fluxo de carga na LT.

Simulações de curto-circuito: a Figura 4-6 representa a configuração das fontes equivalentes de curto-circuito acopladas aos barramentos. Os dados inseridos são a potência e corrente de curto-circuito, e os dados de impedância dessas fontes equivalentes, conforme a 
Tabela 3-1 e Tabela 3-2 do capítulo 3. A configuração da LT é modificada conforme a técnica de repotenciação que se deseja testar durante os curtos-circuitos.

A Figura 3-4 do capítulo 3, esta relacionada com este procedimento, facilitando o entendimento das simulações para curto-circuito.

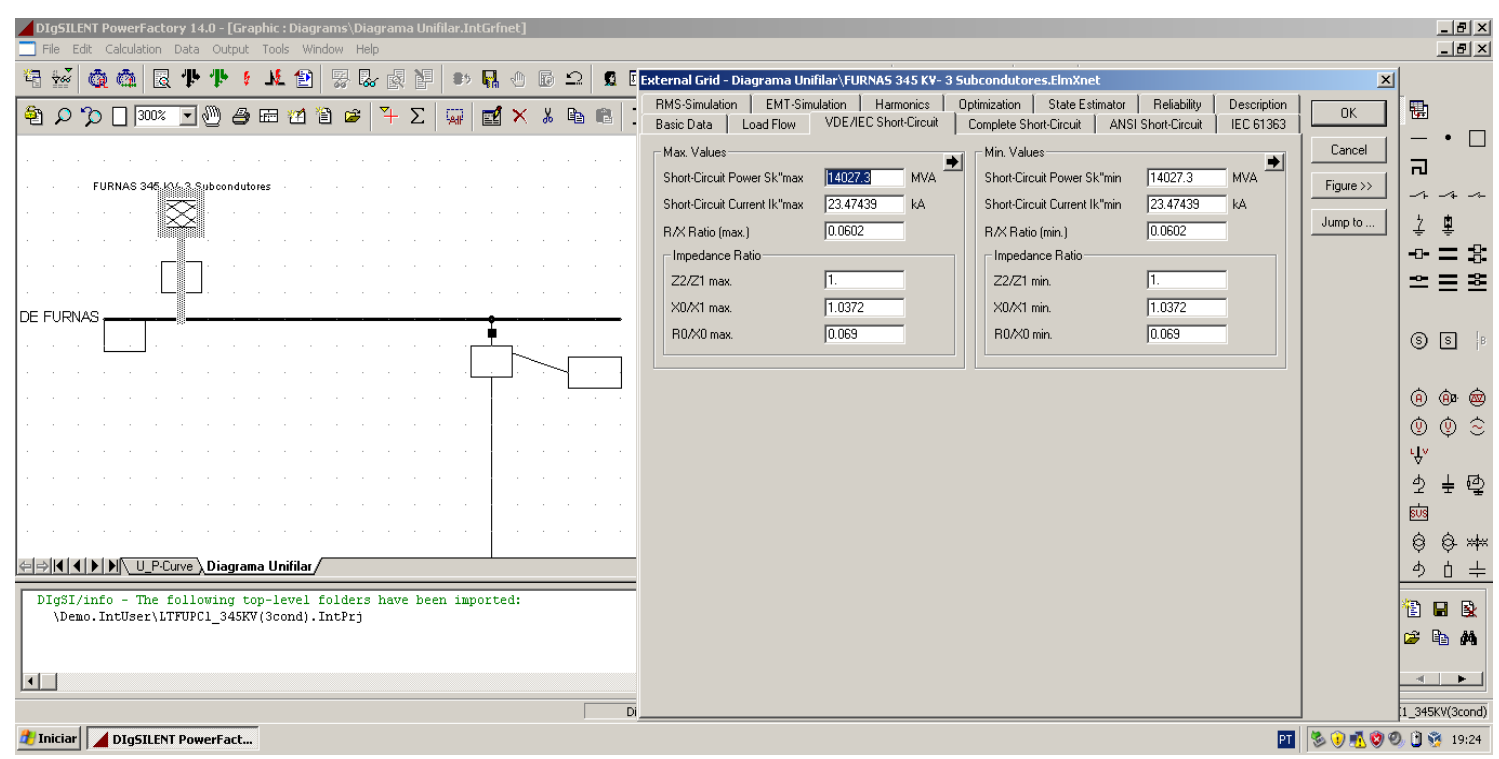

Figura 4-6 - Configuração das fontes de curto-circuito.

A Figura 4-7 ilustra a simulação de uma falta trifásica no barramento de Furnas, com a indicação do comportamento das grandezas a serem colhidas no momento da falta. Este procedimento é efetuado também para faltas no meio da LT e no barramento de Poços de Caldas, alterando o tipo de falta conforme se deseja. 

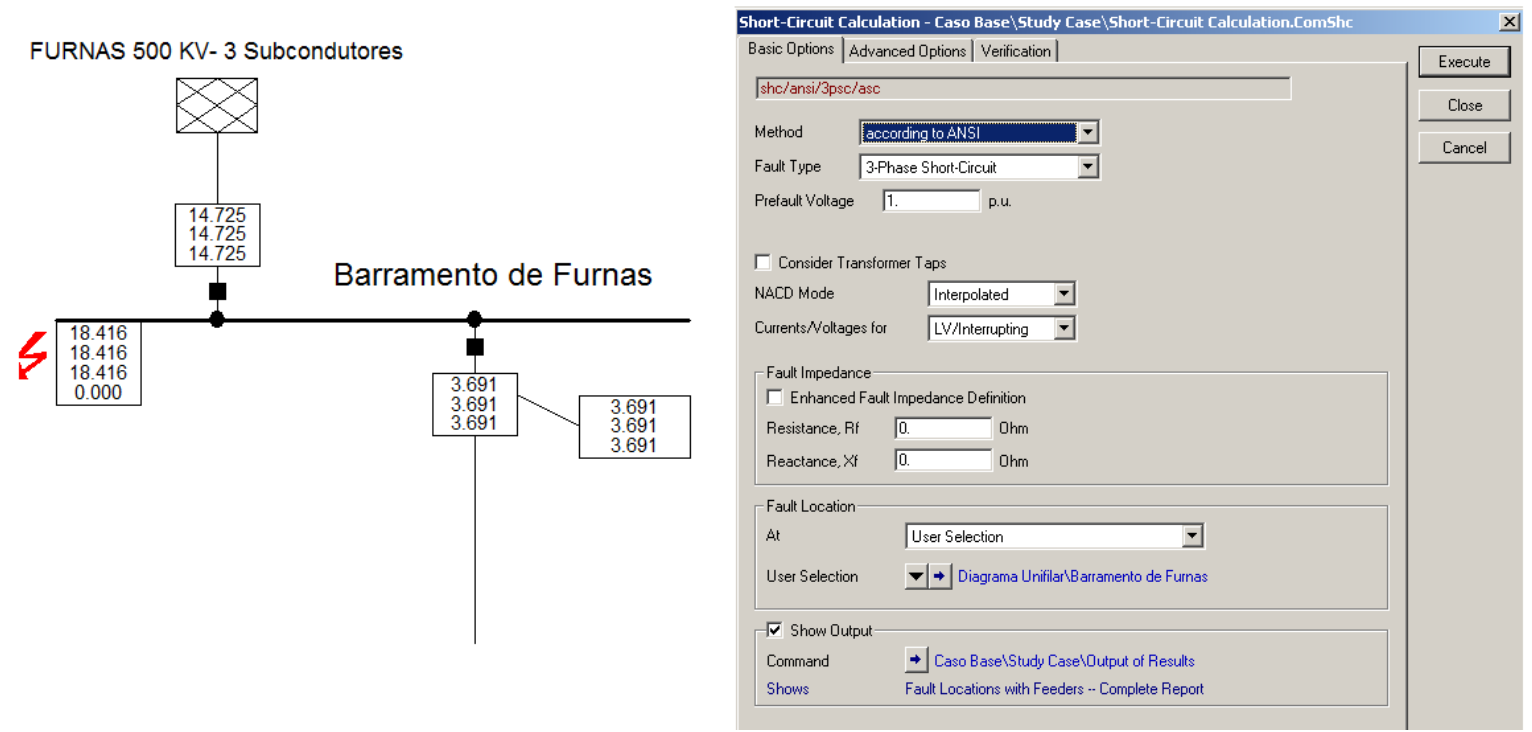

Figura 4-7 - Configuração das faltas na LT.

\subsection{RESULTADOS DAS ANÁLISES DOS FATORES DE DESEMPENHO}

Seguindo as etapas da metodologia de análise proposta, as subseções seguintes apresentam os resultados para cada uma das técnicas de repotenciação consideradas. A configuração original será também considerada para fins de comparação.

\subsubsection{Análise do rendimento}

A análise do rendimento da LT repotenciada empregando-se diferentes técnicas pode ser observada na Figura 4-8, sendo os cálculos efetuados conforme apresentado na equação (3.1). De um modo geral, o rendimento da linha de transmissão sob análise é elevado (acima de $90 \%$ ) para todas as condições testadas.

Observa-se que a LT originalmente montada com dois condutores por fase - Drake 795 (Configuração 1) conseguia transmitir no máximo 750 MW, com rendimento de 93,65\%. A repotenciação por qualquer uma das técnicas mostra-se vantajosa, pois eleva a capacidade de transmissão da LT e aumenta seu rendimento global. Ressalta-se que a potência máxima transmitida encontrada na Figura 4-8 poderá não ser a potência real a ser transmitida na LT, 
pois esta potência pode limitar-se a outros fatores de desempenho, que ocasionalmente serão salientados durante as análises.

A melhoria do rendimento com a elevação da tensão operativa para $500 \mathrm{kV}$ (curvas tracejadas na Figura 4-8) é significativa. Destaque pode ser dado à Configuração 7 (quatro condutores Drake 795, $500 \mathrm{kV}$ ), pois foi a técnica que apresentou maior rendimento à medida em que se aumentava a carga. Em seguida, tem-se a Configuração 8 (três condutores tipo Rail 954, $500 \mathrm{kV}$ ) que apresentou rendimento um pouco inferior à Configuração 7, porém permite maior capacidade de transmissão de potência ativa.

Para os resultados obtidos para as técnicas envolvendo $345 \mathrm{kV}$, observa-se que o emprego de quatro condutores tipo Drake 795 (Configuração 3) apresentou o pior desempenho em comparação com as duas demais técnicas, pois os valores de rendimento foram menores para quaisquer valores de carregamento da LT.

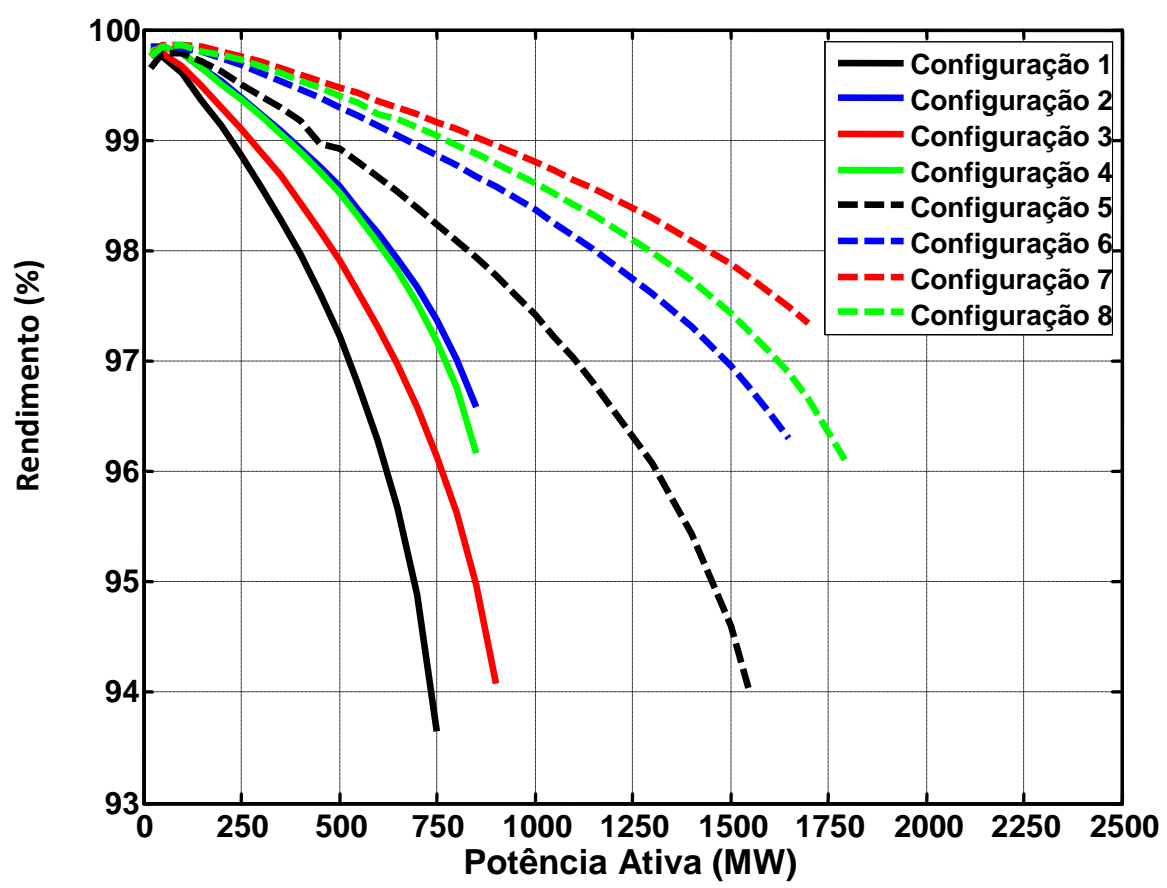

Figura 4-8 - Curvas de rendimento.

Outra análise interessante a ser feita e que mostra a utilidade das curvas de rendimento é avaliar o desempenho das técnicas de repotenciação para condições de 
carregamento inferiores à máxima capacidade. Para tanto, será considerado um fluxo de potência ativa na LT igual a $660 \mathrm{MW}$ do transmissor para o receptor, com fator de potência igual a 0,95. Esse valor de potência ativa corresponde ao dobro da máxima potência que flui atualmente pela linha, segundo informações obtidas diretamente da empresa Eletrobrás Furnas. De posse desse valor de potência ativa, utilizam-se as curvas de rendimento da Figura 4-8 para efetuar a análise. Os resultados apresentados na Tabela 4-1 mostram o rendimento da LT repotenciada segundo as técnicas consideradas. Destaca-se que para a transmissão de 660 MW duas das técnicas de repotenciação em $345 \mathrm{kV}$ apresentaram rendimentos superiores a 97\%, aproximando-se do desempenho das técnicas que envolvem o aumento da tensão operativa. No entanto, as diferenças aumentam à medida que se aumenta o montante de potência transmitida. Logo, no aspecto do rendimento, o aumento esperado da potência a ser transmitida pode ser um fator importante na decisão de qual técnica de repotenciação empregar em função dos custos envolvidos na sua implementação.

Tabela 4-1 - Rendimento para transmissão de $660 \mathrm{MW}$ com fator de potência 0,95 indutivo, em \%.

\begin{tabular}{|c|c|c|c|c|c|c|c|}
\hline Config. 1 & Config. 2 & Config. 3 & Config. 4 & Config. 5 & Config. 6 & Config. 7 & Config. 8 \\
\hline 95,47 & 97,87 & 96,89 & 97,76 & 98,50 & 99,03 & 99,28 & 99,17 \\
\hline
\end{tabular}

\subsubsection{Análise da regulação de tensão}

A regulação da LT consiste basicamente na variação dos valores de tensão eficaz entre o terminal transmissor e o terminal receptor, de no máximo $\pm 10 \%$ para regime permanente, conforme critério adotado por Eletrobrás/Furnas. O limite de $\pm 15 \%$ de regulação pode ser adotado para períodos de oscilações do sistema, visto que a LT pode sofrer períodos de variação de tensão devido a remanejamento de cargas, manobras no fluxo de carga ou maiores carregamentos de curta duração permitidos pelos órgãos regulamentadores.

A Figura 4-9 mostra as curvas de regulação de tensão para os processos de repotenciação. Estando o limite de regulação em 10\%, pode-se observar que originalmente a LT (Configuração 1) transmite uma máxima potência de cerca de 400 MW. O melhor 
desempenho para regulação máxima de $10 \%$ e considerando o sistema em $345 \mathrm{kV}$ foi a técnica que prevê a instalação de quatro condutores por fase, tipo Drake 795 (Configuração 2), proporcionando uma máxima transferência de potência de $520 \mathrm{MW}$. No entanto, os desempenhos das demais técnicas em $345 \mathrm{kV}$ são muito semelhantes.

Analisando o efeito da elevação da tensão operativa para $500 \mathrm{kV}$, pode-se perceber que apenas com o aumento da tensão na LT e mantendo-se a configuração original dos cabos (Configuração 5), consegue-se uma maior transferência de potência na LT, que originalmente era de 420 MW a uma regulação de $10 \%$, e desta vez transfere um máximo de 870 MW para a mesma regulação. Novamente, a técnica que obteve o melhor desempenho foi a Configuração 7.

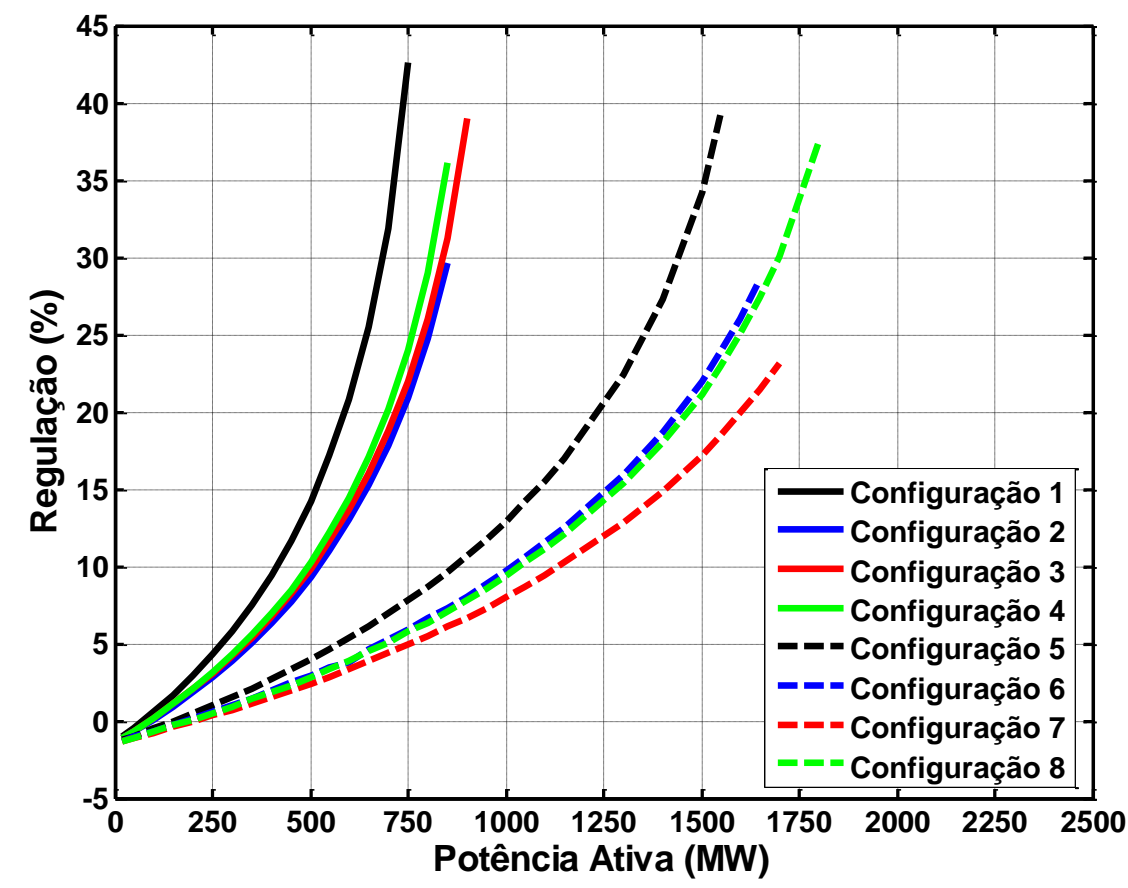

Figura 4-9 - Curvas de regulação de tensão.

Analisando a regulação de tensão para 660 MW, tal como feito na seção anterior, obtiveram-se os valores apresentados na Tabela 4-2. Observa-se que para transmitir o montante de potência desejado e respeitando-se o limite de $10 \%$ para a regulação de tensão, as técnicas que envolvem o aumento da tensão operativa são mais vantajosas. Ressalta-se que 
nessas análises não se está considerando o uso de equipamentos que fazem a compensação de potência reativa. Isso significa que se os mesmos forem empregados, pode-se reduzir a regulação de tensão para valores abaixo dos 10\%, no caso das técnicas previstas nas configurações 2, 3 e 4. Mais uma vez, deve-se fazer uma análise de custo-benefício se a opção de instalar dispositivos compensadores for considerada.

Tabela 4-2 - Regulação de tensão para transmissão de $660 \mathrm{MW}$, fator de potência 0,95 indutivo, em \%.

\begin{tabular}{|c|c|c|c|c|c|c|c|}
\hline Config. 1 & Config. 2 & Config. 3 & Config. 4 & Config. 5 & Config. 6 & Config. 7 & Config. 8 \\
\hline 26,74 & 15,76 & 16,58 & 17,65 & 6,30 & 4,80 & 3,95 & 4,61 \\
\hline
\end{tabular}

\subsubsection{Análise da capacidade de condução de corrente}

O limite de corrente da LT em estudo, calculado para a temperatura de projeto de $50^{\circ}$ Celsius, é de 1.218 A (Ampéres), para carregamento normal da LT, e de 1.734 A para condições de carregamento de emergência, com temperatura de projeto de $80^{\circ} \mathrm{C}$.

Para efeito de comparação das técnicas de repotenciação, o limite de corrente de 1.218 A para a LT será considerado. Neste caso, não serão necessários cálculos de novas flechas máximas para os vãos da LT, pois nos casos de repotenciação com o lançamento de mais cabos e o recondutoramento da LT por cabos de maior bitola, a impedância da LT diminui, contribuindo para o menor aquecimento do cabo e consequentemente uma corrente menor para uma mesma potência transmitida. Os resultados podem ser analisados por meio das curvas de capacidade de condução de corrente mostradas na Figura 4-10. Nesta figura, pode-se observar que os desempenhos das técnicas de repotenciação em 345 kV são bastante semelhantes entre si, o mesmo ocorrendo com aquelas em $500 \mathrm{kV}$. Naturalmente, as técnicas das configurações de 5 a 8 apresentam melhor desempenho do que as demais, visto que elas consideram a elevação da tensão para $500 \mathrm{kV}$. Isso significa que, considerando o limite de corrente de 1.218 A, o aumento da capacidade de transmissão de potência ativa das 
configurações de 5 a 8 atinge cerca de 900 MW, contra algo em torno de 500 MW referentes às configurações 2 a 4 .

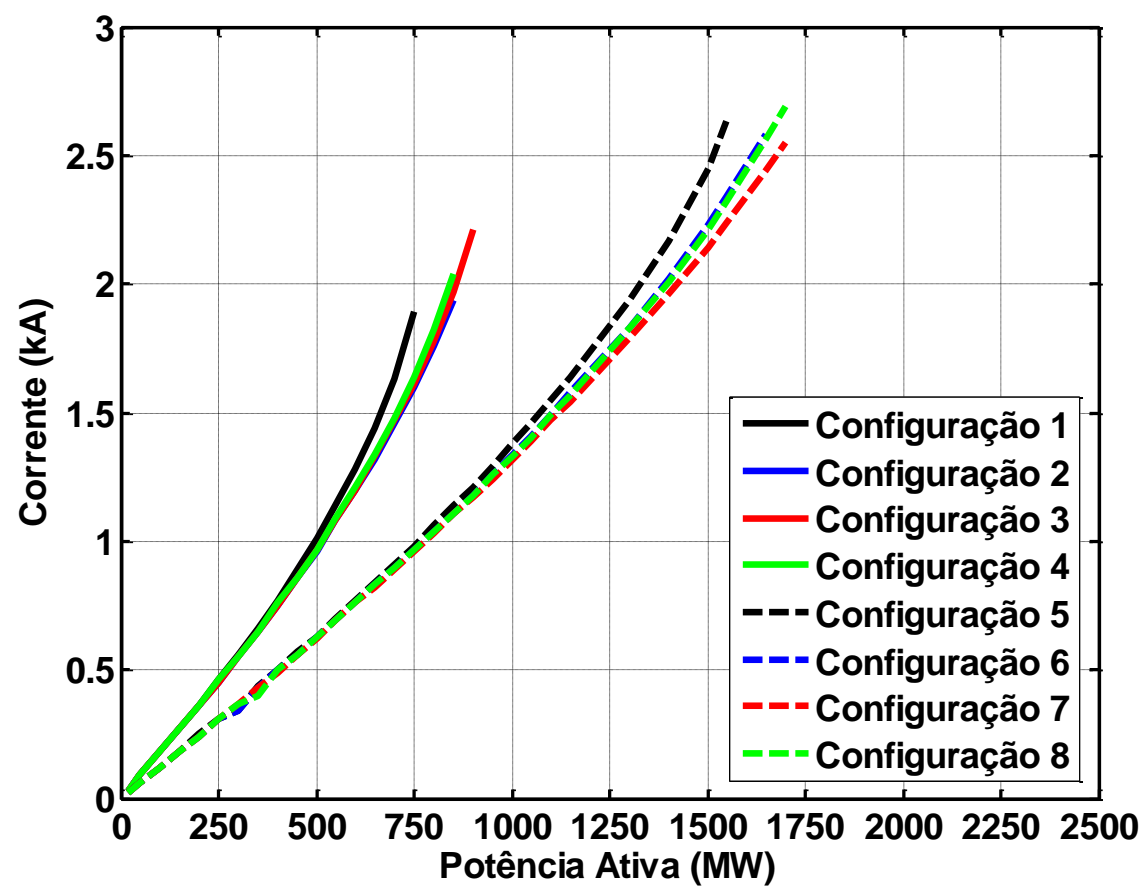

Figura 4-10 - Curvas de capacidade de condução de corrente.

\subsubsection{Análise do limite de estabilidade de tensão (Curvas PV)}

A Figura 4-11 mostra as curvas PV considerando as alternativas de repotenciação admitidas neste trabalho. Observa-se claramente que as técnicas que envolvem a elevação da tensão operativa da LT proporcionam uma margem de estabilidade de tensão muito maior do que as outras técnicas. Isto implica em afirmar que operando em $500 \mathrm{kV}$, a LT consegue transmitir uma potência muito maior do que na condição atual de operação sem haver colapso de tensão. Todas as técnicas de repotenciação em $345 \mathrm{kV}$ apresentam desempenhos semelhantes, e destaque se dá à Configuração 7, por apresentar os melhores resultados entre todas as técnicas avaliadas.

De maneira semelhante ao que foi feito anteriormente, as curvas PV serão utilizadas para avaliar o valor de tensão no terminal receptor da LT para uma potência transmitida de 660 MW, e considerando todas as técnicas de repotenciação. Os resultados são apresentados 
na Tabela 4-3, em que se evidencia a superioridade de todas as técnicas de repotenciação em relação à configuração inicial, em especial à superioridade daquelas referentes às configurações 5 a 8 . Um fato interessante é o comportamento muito semelhante das técnicas 2, 3 e 4. Logo, os fatores técnicos relacionados ao limite de estabilidade de tensão não serão determinantes na escolha de uma delas.

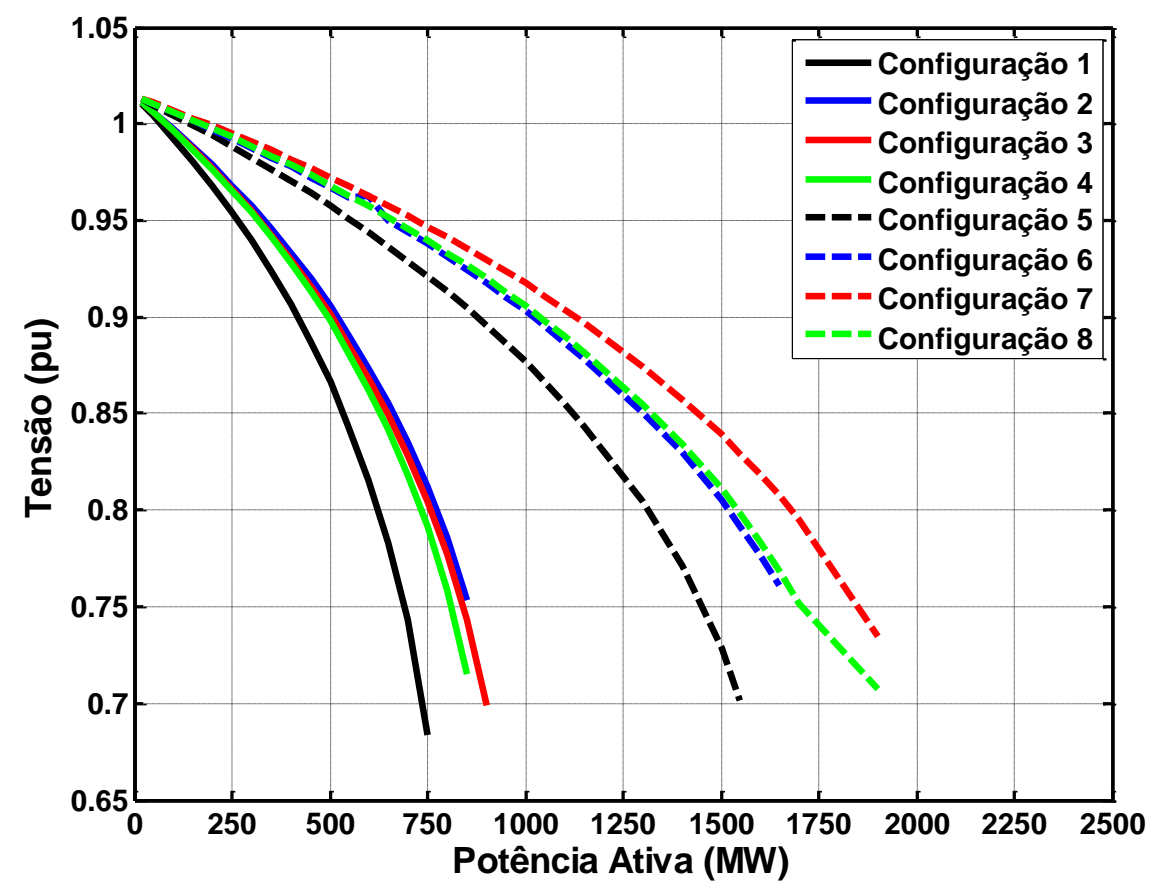

Figura 4-11 - Curvas PV.

Tabela 4-3 - Tensão no receptor para $660 \mathrm{MW}$ para transmissão de $660 \mathrm{MW}$ com fator de potência 0,95 indutivo, em pu.

\begin{tabular}{|c|c|c|c|c|c|c|c|}
\hline Config. 1 & Config. 2 & Config. 3 & Config. 4 & Config. 5 & Config. 6 & Config. 7 & Config. 8 \\
\hline 0,77 & 0,85 & 0,85 & 0,84 & 0,94 & 0,95 & 0,96 & 0,95 \\
\hline
\end{tabular}

Outra análise importante refere-se à máxima potência ativa que a LT pode transmitir sem violar o limite inferior de tensão de regime permanente. De acordo com a resolução no. 505 da ANEEL, este valor é de 95\% da tensão contratada para sistemas com nível de tensão superior a 230 kV, Aneel (2001). A Figura 4-12 auxilia nessa análise. Ela representa a Figura 4-11 ampliada e com uma linha identificando o valor de 0,95 pu de tensão. Nela se observa que as técnicas correspondentes às configurações 2, 3 e 4 apresentam desempenho semelhante 
sendo que a máxima potência transmitida está em torno de $380 \mathrm{MW}$. Este valor pode ser elevado se dispositivos compensadores da potência reativa forem instalados na LT. Por outro lado, observa-se que as diferenças de desempenho entre as técnicas referentes às configurações 5 a 8 são mais evidentes, com destaque à configuração 7, a qual permite uma potência máxima de $720 \mathrm{MW}$.

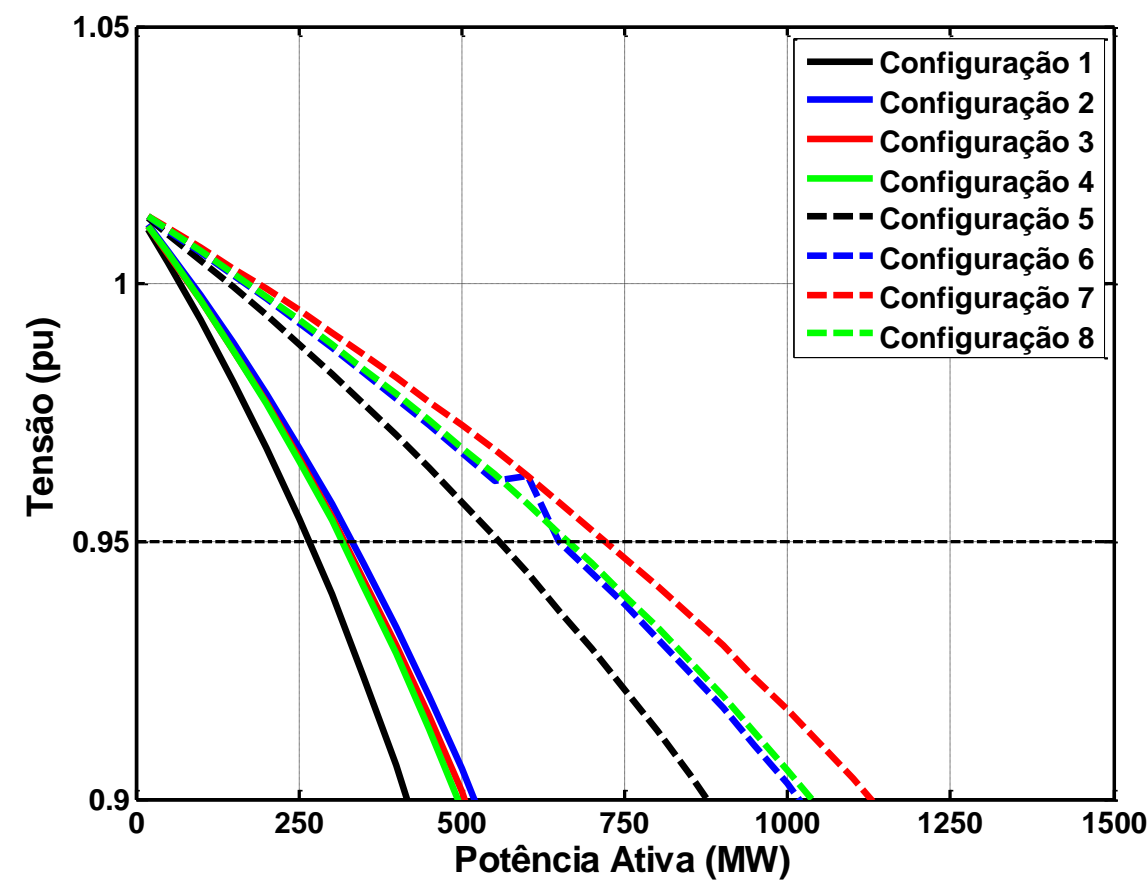

Figura 4-12 - Curvas PV - limite inferior de tensão de regime permanente.

\subsubsection{Análise das perdas na LT}

Nesta seção são analisadas as perdas por efeito Joule e por efeito Corona na LT sob estudo. As primeiras são mostradas por meio de curvas de perdas, construídas com o auxílio do programa DIgSILENT PowerFactory, conforme ilustra a Figura 4-13.

Na Figura 4-13 evidencia-se o melhor desempenho da técnica de repotenciação referente à configuração 7 em relação às demais, pois a corrente que circula pela linha para um determinado nível de potência é inferior, causando a redução nas perdas por efeito Joule. Percebe-se também que, para as técnicas em $345 \mathrm{kV}$, os desempenhos das configurações 2 e 4 são muito semelhantes em relação às perdas elétricas. Analisando o caso em que a potência 
transmitida é igual a $660 \mathrm{MW}$, a Tabela 4-4 fornece as perdas por efeito Joule de cada configuração, o que confirma as informações anteriormente mencionadas.

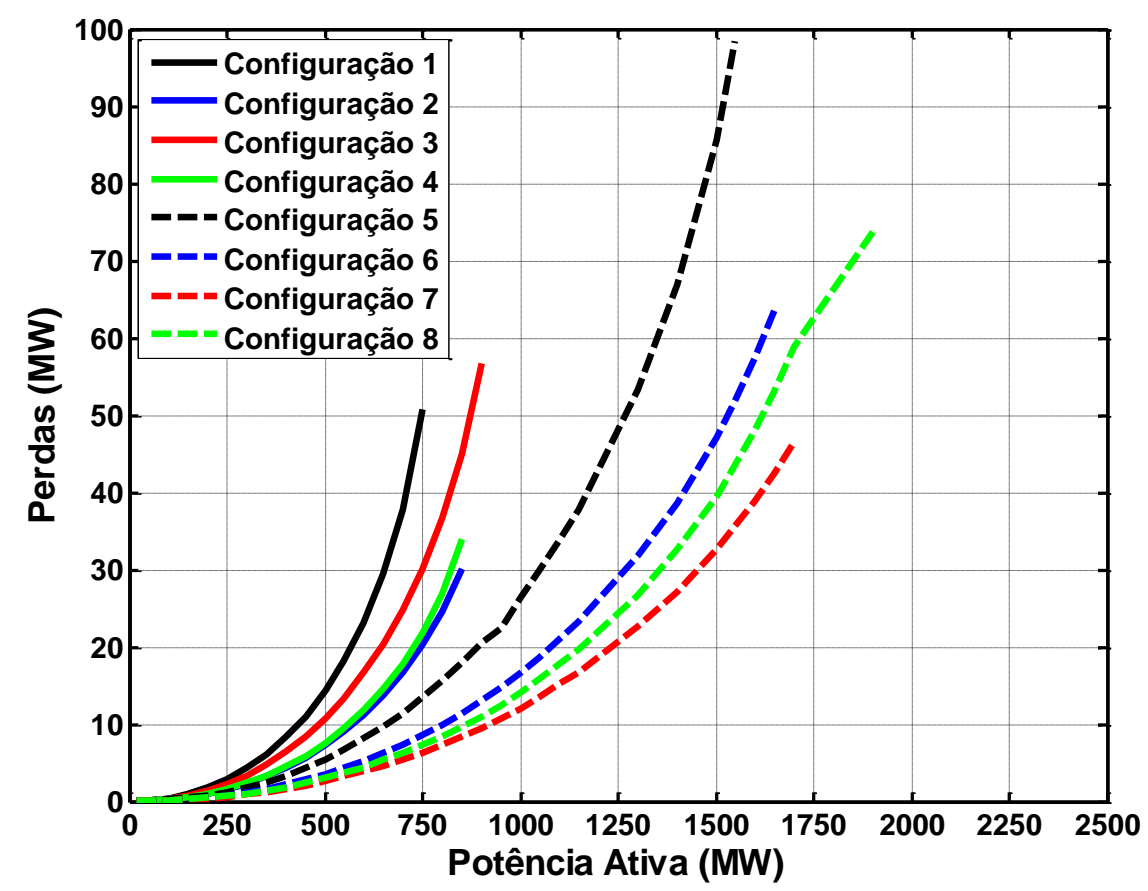

Figura 4-13 - Curvas das perdas por efeito Joule.

Tabela 4-4 - Perdas por efeito Joule na LT para transmissão de 660 MW com fator de potência 0,95 indutivo, em MW.

\begin{tabular}{|c|c|c|c|c|c|c|c|}
\hline Config. 1 & Config. 2 & Config. 3 & Config. 4 & Config. 5 & Config. 6 & Config. 7 & Config. 8 \\
\hline 31,06 & 14,35 & 21,24 & 15,14 & 10,06 & 6,50 & 4,79 & 5,51 \\
\hline
\end{tabular}

As perdas por efeito Corona são apresentadas na Tabela 4-5 e foram calculadas conforme apresentado na seção 3.2.5 desta dissertação. Nesta tabela, admitiu-se que a LT transferia potência equivalente à corrente de $1.218 \mathrm{~A}$.

Os valores das perdas por efeito Corona para técnicas de repotenciação em $500 \mathrm{kV}$ são maiores que os valores das perdas corona para técnicas de repotenciação em $345 \mathrm{kV}$, porém afetam menos o rendimento da LT, devido à maior quantidade de potência transferida que o sistema repotenciado em $500 \mathrm{kV}$ oferece.

Observa-se também que quanto mais condutores no feixe de cada fase, menores as perdas por efeito Corona para tempo bom, e já para o tempo ruim a relação não é equivalente, 
pois o coeficiente de perdas $(\mathrm{k})$ tem variação irregular devido à geometria diferente dos cabos condutores na LT.

Tabela 4-5 - Perdas por efeito Corona na LT.

\begin{tabular}{|c|c|c|}
\hline \multirow{2}{*}{ Técnicas } & \multicolumn{2}{|c|}{ Perdas Corona (kW/km) } \\
\cline { 2 - 3 } & Tempo Bom & Tempo Ruim \\
\hline Configuração 1 & 4,73 & 9,55 \\
\hline Configuração 2 & 3,99 & 24,89 \\
\hline Configuração 3 & 3,61 & 27,36 \\
\hline Configuração 4 & 3,41 & 15,21 \\
\hline Configuração 5 & 6,94 & 20,85 \\
\hline Configuração 6 & 5,79 & 41,49 \\
\hline Configuração 7 & 5,23 & 76,20 \\
\hline Configuração 8 & 5,28 & 38,15 \\
\hline
\end{tabular}

\subsubsection{Análise do efeito corona visual}

Para a determinação do efeito Corona visual da LT, utilizou-se o programa computacional "Campo" do CEPEL, que calculou o campo elétrico superficial dos condutores para todas as técnicas envolvidas na repotenciação da LT, conforme apresentado na seção 3.2.6. O campo elétrico superficial foi calculado para a corrente máxima da LT, sendo 1.218 A.

A Tabela 4-6 retrata os valores das grandezas calculadas nas simulações e a conclusão da ocorrência do efeito Corona visual. Nota-se que quanto maior o número de condutores presentes em cada fase, menor é o campo elétrico superficial, devido a uma melhor distribuição deste entre os condutores. Dentre os casos avaliados, observou-se que a LT apresentará corona visual apenas se for empregada a técnica de repotenciação correspondente à configuração 5 . 
Tabela 4-6 - Determinação do efeito Corona visual na LT.

\begin{tabular}{|c|c|c|c|}
\hline \multirow{2}{*}{ Técnicas } & $\begin{array}{c}\text { C.E. } \\
\text { Superficial } \\
\text { ou E (kV/cm) }\end{array}$ & $\begin{array}{c}\text { Ecrv } \\
(\mathbf{k V / c m})\end{array}$ & $\begin{array}{c}\text { Presença de } \\
\text { Corona Visual }\end{array}$ \\
\cline { 2 - 4 } & \multicolumn{2}{|c|}{ Se C.E > Ecrv então ocorre Corona visual } \\
\hline Configuração 1 & 14,85 & 19,14 & Não \\
\hline Configuração 2 & 12,59 & 19,14 & Não \\
\hline Configuração 3 & 11,38 & 19,14 & Não \\
\hline Configuração 4 & 12,07 & 21,48 & Não \\
\hline Configuração 5 & $\mathbf{2 3 , 0 0}$ & $\mathbf{2 1 , 2 8}$ & Sim \\
\hline Configuração 6 & 18,23 & 19,14 & Não \\
\hline Configuração 7 & 16,49 & 19,14 & Não \\
\hline Configuração 8 & 17,49 & 21,28 & Não \\
\hline
\end{tabular}

\subsubsection{Análise da rádio interferência}

A Tabela 4-7 apresenta os valores de rádio interferência (RI) calculados para as técnicas de repotenciação consideradas neste trabalho, conforme procedimento apresentado na seção 3.2.7. Os valores de campo elétrico e campo magnético também são apresentados nesta tabela para melhor relacionar os resultados, mas serão novamente apresentados por meio de gráficos, na próxima seção desta dissertação.

Os cálculos de rádio interferência foram efetuados considerando o ponto de medição no limite da faixa de servidão da LT, ou seja, a 30 metros de distância da fase central, visto que a LT tem uma faixa de servidão de $60 \mathrm{~m}$ de comprimento.

Analisando a Tabela 4-7 é possível concluir que os valores de RI são maiores para tensões em $500 \mathrm{kV}$, assim como também é visível que há uma pequena diminuição no valor de RI quando se aumenta a bitola dos condutores de um feixe, e uma diminuição considerável desses valores quando se aumenta o número de condutores no feixe.

Os valores calculados de RI para todas as simulações enquadram-se dentro dos limites estabelecidos segundo ONS (2000), sendo superiores ao valor mínimo de $24 \mathrm{~dB}$.

Tabela 4-7 - Rádio interferência na LT.

\begin{tabular}{|c|c|c|c|c|}
\hline Técnicas & C.E & C.M & $\begin{array}{c}\text { R.I. } \\
\text { (Tempo bom) }\end{array}$ & $\begin{array}{c}\text { R.I. } \\
\text { (Sob chuva) }\end{array}$ \\
\hline
\end{tabular}




\begin{tabular}{|l|c|c|c|c|}
\hline & $\begin{array}{c}\text { Limite: } \\
\mathbf{4 , 2} \mathbf{~ k V / m}\end{array}$ & $\begin{array}{c}\text { Limite: } \\
\mathbf{8 3 3} \mathbf{~ m G}\end{array}$ & $\begin{array}{c}\text { Limite Mínimo: } \\
\mathbf{2 4} \mathbf{~ d B}\end{array}$ & $\begin{array}{c}\text { Limite Mínimo: } \\
\mathbf{2 4} \mathbf{~ d B}\end{array}$ \\
\hline Configuração 1 & 1,85 & 483,57 & 62,26 & 79,26 \\
\hline Configuração 2 & 2,09 & 485,56 & 56,37 & 69,37 \\
\hline Configuração 3 & 2,30 & 486,29 & 41,96 & 58,96 \\
\hline Configuração 4 & 2,12 & 485,56 & 49,08 & 66,08 \\
\hline Configuração 5 & 2,68 & 483,57 & 98,12 & 115,12 \\
\hline Configuração 6 & 3,30 & 485,56 & 73,32 & 90,32 \\
\hline Configuração 7 & 3,34 & 486,29 & 67,13 & 84,13 \\
\hline Configuração 8 & 3,17 & 485,56 & 71,39 & 88,39 \\
\hline
\end{tabular}

\subsubsection{Análise do campo elétrico}

Os cálculos para determinação do campo elétrico da LT foram efetuados para todas as técnicas de repotenciação aplicadas na LT, e são ilustrados na Figura 4-14. Os valores dos campos elétricos representados nesta figura são os mesmos da Tabela 4-7. No entanto, é interessante fazer uma amostragem dos campos através de uma contribuição gráfica para enriquecer as condições de análise. O eixo horizontal do gráfico corresponde à distância de medição do campo elétrico, dada em metros, onde o ponto de referência é a fase central da LT que está situada no ponto “0” metros.

Nota-se que o campo elétrico calculado conforme descrito na seção 3.2 .8 possui valores maiores para tensões em $500 \mathrm{kV}$, e o mesmo acontece quando se aumenta o número de condutores do feixe, pois há um somatório dos campos de cada condutor. Observa-se também que com o aumento da bitola dos cabos condutores, quase não se altera o campo elétrico na LT, devido pouca diferença na bitola entre os cabos testados.

Os valores dos campos elétricos possuem seus valores de pico nos pontos próximos às fases externas da LT, conforme indicado no gráfico da Figura 4-14. 


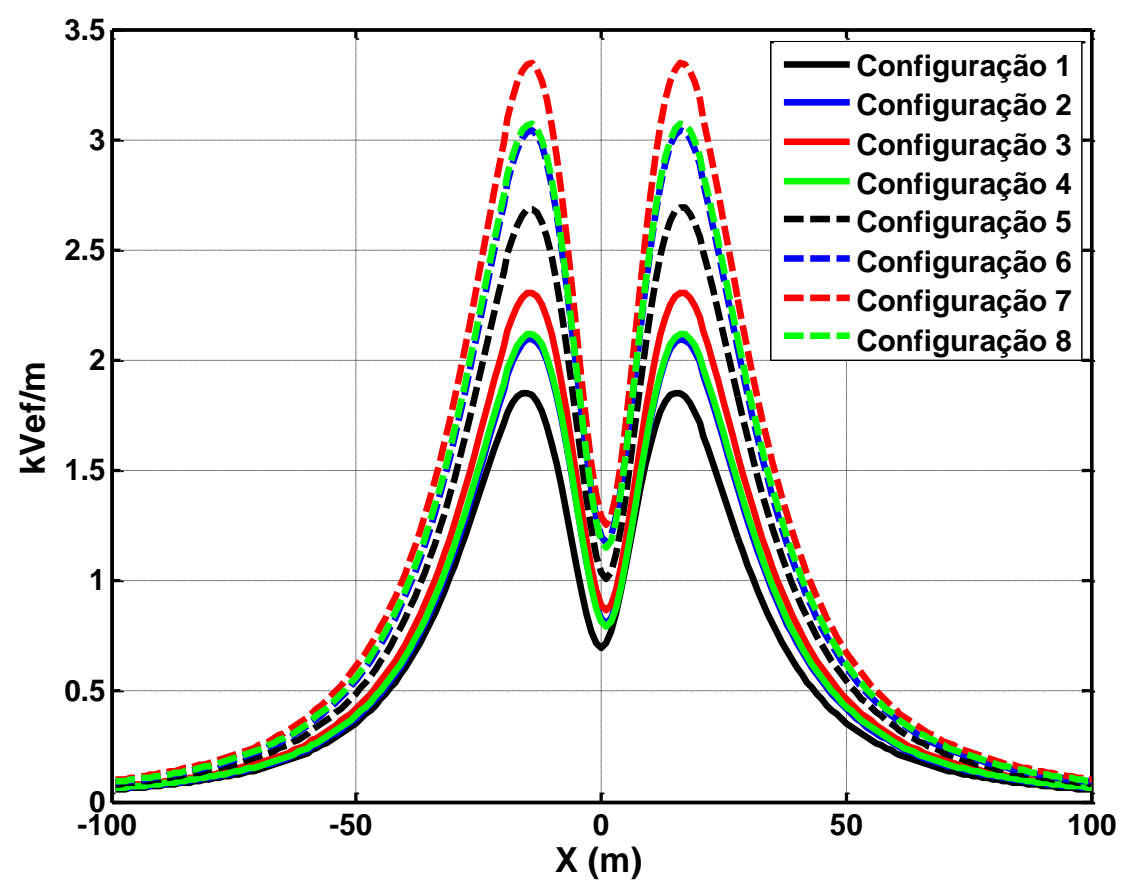

Figura 4-14 - Campo elétrico.

Assim é certo dizer que os valores calculados de campo elétrico para as técnicas de repotenciação aplicadas na LT em análise encontram-se dentro dos limites estabelecidos pelas normas da ONS, com valores sempre abaixo de 4,2 kVef $/ \mathrm{m}$, medidos a um metro do solo e no limite da faixa de servidão.

\subsubsection{Análise do campo magnético}

Os valores encontrados para campo magnético para as simulações de repotenciação da LT sob estudo enquadram-se dentro dos limites estabelecidos pela norma, sendo todos abaixo de $833 \mathrm{mG}$, conforme ONS (2000). A Figura 4-15 apresenta o campo magnético calculado para todas as técnicas de repotenciação analisadas. Assim como no campo elétrico, o eixo horizontal da Figura 4-15 mede o distanciamento da fase central, que tem sua referência no ponto " 0 ” metros.

O campo magnético teve valores praticamente iguais para todas as técnicas simuladas, inclusive para a variação dos níveis de tensão, devido ao ponto de medição do campo magnético estar a uma grande distância (30 m da fase central), no limite da faixa de 
servidão, fazendo com que o campo magnético se propague a baixos valores. Também este valor igual deve-se ao campo magnético estar relacionado com a corrente na LT, que foi adotada 1.218 A para todas as configurações.

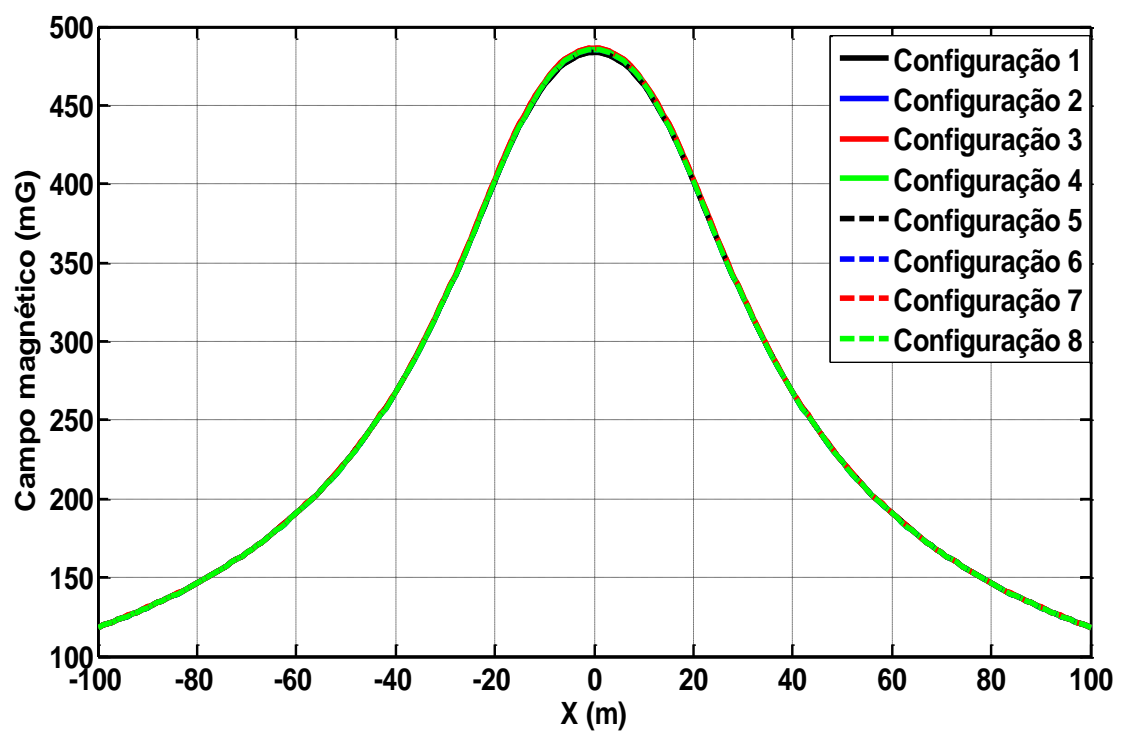

Figura 4-15 - Campo Magnético

\subsection{RESULTADOS DAS ANÁLISES DOS ÍNDICES DE MÉRITO AGREGADO}

Nesta seção, os índices propostos na seção 3.3 são calculados, e servirão como suporte na avaliação de qual técnica de repotenciação é mais vantajosa para ser implantada. Todos os índices utilizam a corrente normal de operação da linha a $50^{\circ} \mathrm{C}$ para calcular uma potência de referência ou potência de base. Neste trabalho, esse valor de corrente corresponderá a 1.218 A, que é a corrente considerando os condutores tipo Drake 795, e o valor de tensão será $345 \mathrm{kV}$, correspondendo à classe de tensão operativa atual da LT. Sendo assim, tem-se que o valor da potência de base é igual a:

$$
P_{N}=\sqrt{3} \cdot V_{N} \cdot I_{N}=\sqrt{3} \cdot 345.000 \cdot 1.218=727,83 M V A
$$


Os valores dos índices de desempenho são mostrados na Tabela 4-8. Inicialmente, observe o desempenho das técnicas em $345 \mathrm{kV}$ (configurações de 2 a 4). Os valores marcados em vermelho destacam a técnica que obteve o melhor desempenho segundo os índices propostos. Neste caso, a configuração 2 foi a que apresentou o maior valor para quase todos os índices considerados. Em uma segunda análise, observa-se que dentre as técnicas em $500 \mathrm{kV}$, a configuração 7 foi aquela que apresentou melhor desempenho (os maiores valores estão marcados em azul). Por fim, dentre todas as técnicas consideradas, a configuração 7 apresentou os maiores valores para todos os índices propostos.

Tabela 4-8 - Índices de Mérito Agregado.

\begin{tabular}{|c|c|c|c|c|}
\hline Técnicas & $\mathbf{i}_{\text {MAXC }}$ & $\mathbf{i}_{\text {MAXc_V }}$ & $\mathbf{i}_{\text {MAX } \eta_{-} \mathbf{V}}$ & $\mathbf{i}_{\text {MAXR_V }}$ \\
\hline Configuração 1 & 0,03 & $-0,66$ & 0,34 & 7,99 \\
\hline Configuração 2 & 0,17 & $\mathbf{- 0 , 5 4}$ & $\mathbf{0 , 4 5}$ & $\mathbf{1 0 , 0 8}$ \\
\hline Configuração 3 & $\mathbf{0 , 2 4}$ & $-0,56$ & 0,43 & 9,35 \\
\hline Configuração 4 & 0,17 & $-0,57$ & 0,42 & 8,87 \\
\hline Configuração 5 & 0,78 & $-0,17$ & 0,75 & 11,34 \\
\hline Configuração 6 & 0,87 & $-0,12$ & 0,82 & 13,23 \\
\hline Configuração 7 & $\mathbf{1 , 1 1}$ & $\mathbf{- 0 , 0 0 7}$ & $\mathbf{0 , 9 8}$ & $\mathbf{1 5 , 1 7}$ \\
\hline Configuração 8 & 0,92 & $-0,05$ & 0,91 & 13,51 \\
\hline
\end{tabular}

Na Tabela 4-8 observa-se ainda que todos os valores referentes ao índice $\mathbf{i}_{\mathbf{M A X C}} \mathbf{} \mathbf{v}$ são negativos. Isso ocorreu porque a potência referente ao valor de $1.218 \mathrm{~A}\left(\mathrm{P}_{\mathrm{N}}\right)$ é maior do que os valores máximos de potência ativa que resultam na tensão no receptor igual a 0,95 pu. Esses valores negativos também indicam que se é desejado operar com potência igual à $\mathrm{P}_{\mathrm{N}}$, torna-se necessário usar dispositivos compensadores de potência reativa, caso contrário a tensão em regime permanente será inferior a 0,95 pu.

Ressalta-se que no Anexo B será apresentado um exemplo de cálculo dos IMA.

\subsection{IDENTIFICAÇÃO DE MUDANÇAS NA LT}

A análise das técnicas de repotenciação também deve considerar possíveis alterações na geometria da LT em função da técnica empregada. Sendo assim, utilizando os 
procedimentos apresentados no anexo B, esta seção apresenta uma análise das possíveis alterações na LT devido à elevação da tensão operativa e esforços mecânicos devido ao lançamento de mais condutores no feixe.

\subsubsection{Isolamento à máxima tensão operativa}

A Tabela 4-9 apresenta os valores calculados para as distâncias mínimas de segurança dos condutores energizados, conforme apresentado no Anexo C. A condição identificada como "Original” apresenta as distâncias empregadas na LT em análise. Ressaltase que haverá a necessidade do aumento do comprimento da cadeia de isoladores para as técnicas de repotenciação em $500 \mathrm{kV}$, para atender as distâncias de segurança dos cabos para a estrutura. A distância vertical em relação ao solo diminuirá para 19,3 m, porém ainda enquadra-se nos limites conforme Tabela C-1, apresentada no Anexo C.

Para a distância horizontal entre fases, não haverá necessidade de mudanças, pois o espaçamento de 10,6 m é suficiente para manter os níveis de isolação, mesmo na tensão de $500 \mathrm{kV}$ que teve sua distância mínima calculada em 6,6 m. A adoção de cadeia de isoladores duplos para a fase central pode ser considerada para garantir a isolação da LT em situações quando os balanços entre fase central e fases externas da LT têm sentidos opostos. Este procedimento é adotado para evitar qualquer balanço da cadeia de isoladores da fase central.

Tabela 4-9 - Tabela das distâncias mínimas de segurança para máxima tensão operativa

\begin{tabular}{|c|c|c|c|}
\hline Condições & $\begin{array}{c}\text { Distância } \\
\text { Horizontal (m) }\end{array}$ & $\begin{array}{c}\text { Distância } \\
\text { Vertical (m) }\end{array}$ & $\begin{array}{c}\text { Distância p/ } \\
\text { Estruturas (m) }\end{array}$ \\
\hline Original & $\mathbf{1 0 , 6 0}$ & $\mathbf{2 0 , 0 0}$ & $\mathbf{3 , 5 0}$ \\
\hline $\begin{array}{c}\text { Valores } \\
\text { Calculados em } \\
345 \mathrm{kV}\end{array}$ & $\begin{array}{c}\text { Manteve-se } \\
\text { original }\end{array}$ & $\begin{array}{c}\text { Manteve-se } \\
\text { original }\end{array}$ & $\begin{array}{c}\text { Manteve-se } \\
\text { original }\end{array}$ \\
\hline $\begin{array}{c}\text { Valores } \\
\text { Calculados em } \\
500 \mathrm{kV}\end{array}$ & $\begin{array}{c}\text { Calculado 6,60 } \\
\text { Manteve-se } \\
10,6\end{array}$ & 19,30 & 4,20 \\
\hline
\end{tabular}




\subsubsection{Condições mecânicas}

Os estudos quanto às condições mecânicas da LT não serão aprofundados nesta dissertação, pois estenderia a mesma a assuntos fora do objetivo principal. No entanto, uma breve discussão sobre esse tópico é apresentada nesta seção.

As técnicas de repotenciação consideradas nesta dissertação não afetarão significativamente as condições mecânicas das estruturas, pois os lançamentos dos cabos adicionais ou o recondutoramento ocasionarão esforços mecânicos adicionais já previstos, devido à folga de fatores de segurança mecânicos no projeto original da LT, neste caso.

Uma analogia pode ser feita para a LT repotenciada e outras LTs de Furnas que possuem carregamento mecânico iguais, com três e quatro condutores por fase com tensões até $500 \mathrm{kV}$ para o mesmo tipo de estrutura. Os carregamentos destas LTs são considerados assim:

- Carregamentos transversais;

- Carregamentos verticais;

- Carregamentos longitudinais.

Para representação desses carregamentos mecânicos serão feitas considerações adotadas nos projetos das linhas de transmissão de 345 e 500 kV de Furnas, conforme Amaral (1976).

Os carregamentos transversais são causados pela pressão de vento nas torres, ferragens, isoladores e pela componente transversal da tensão dos cabos na aplicação de ângulos. Para hipóteses de carregamento que não consideram a ação do vento, não se tem carregamentos transversais tangentes, enquanto que em torres de ângulo, ao invés de usar a tensão máxima dos cabos, usa-se a tensão de maior ocorrência. 
Os carregamentos verticais são causados pelo peso dos cabos, isoladores e ferragens, bem como por condições temporárias durante as atividades e construção ou manutenção e pelo peso da própria torre.

Os carregamentos longitudinais em torres de suspensão podem ser provocados por fatores como:

- Rompimento de uma fase ou cabo para-raios;

- Esforços introduzidos durante o lançamento;

- Falha na cadeia de isoladores da torre adjacente;

- Abaixamento do condutor em uma torre para manutenção;

- Queda de torre adjacente;

- Ventos a $45^{\circ}$ ou paralelos à linha.

Projetar uma torre capaz de resistir a qualquer tipo de solicitação que ela possa vir a sofrer durante sua vida útil certamente conduziria a uma excessiva penalização de custo, uma vez que a ocorrência de alguns desses fatores é altamente improvável. Por outro lado, a ocorrência de cargas longitudinais, sem vento, durante o lançamento dos cabos é praticamente certa, o que torna tal fator preponderante na escolha das cargas longitudinais.

Existem no sistema de Furnas LTs com até quatro condutores, idênticos aos utilizados nas configurações 3 e 7, conforme descrito na Seção 4.2. Além disso, há linhas com o mesmo tipo de estrutura, tamanho de vãos, condições geográficas e climatológicas, garantindo condições de suportabilidade de pesos e esforços mecânicos para a repotenciação da LT sob estudo.

A velocidade máxima do vento de $116 \mathrm{~km} / \mathrm{h}$ para as condições encontradas na região da LT estudada não implicará em esforços mecânicos adicionais em relação aos novos cabos, pois estas configurações já existem em Furnas, conforme mencionado anteriormente. 
Os fabricantes de isoladores recomendam que em nenhum caso o isolador seja submetido a um esforço superior a $60 \%$ de sua resistência eletromecânica combinada. Isto equivale a um fator de segurança de 1,65 e corresponde a uma carga máxima de aproximadamente $6.870 \mathrm{~kg}$ para os isoladores da LT repotenciada, coincidindo com os valores de projeto. O peso de quatro condutores tipo Drake 795 em um feixe, sendo esta a configuração com maior peso de cabos, é de aproximadamente $6.512 \mathrm{~kg}$. Esta condição está dentro dos limites de carga das estruturas e não há necessidade de grandes modificações nas mesmas, apenas a mudança de grampos para ancoragem na cadeia de isoladores.

Nas linhas de $345 \mathrm{kV}$ e $500 \mathrm{kV}$ repotenciadas, onde existirem vãos atípicos e que o relevo ocasione maiores esforços nas estruturas e isoladores, pode-se então usar cadeias de suspensão duplas, ou isoladores de maior resistência eletromecânica combinada.

Os espaçadores utilizados na repotenciação da LT podem ser do mesmo tipo do projeto original, com o modelo adequado ao número de condutores no feixe. Os espaçadores podem ser introduzidos em maior número ao longo do vão, pois reduzem a amplitude das vibrações provocadas pelo vento.

\subsection{IDENTIFICAÇÃO DA MELHOR TÉCNICA DE REPOTENCIAÇÃO}

A Tabela 4-10 apresenta uma síntese do comportamento dos fatores de desempenho, considerando a transmissão de 660MW com fator de potência 0,95 indutivo. Nota-se que os valores referentes às configurações 2 e 7 são os mais eficientes para os níveis de tensão de $345 \mathrm{kV}$ e $500 \mathrm{kV}$, respectivamente. Esta avaliação juntamente com a efetuada através da Tabela 4-8, referente aos IMA, permitem identificar as duas configurações (2 e 7) como as mais eficientes na repotenciação da LTFUPC1. 
Tabela 4-10 - Síntese dos fatores de desempenho.

\begin{tabular}{|c|c|c|c|c|c|c|c|c|c|c|c|}
\hline نَّ & 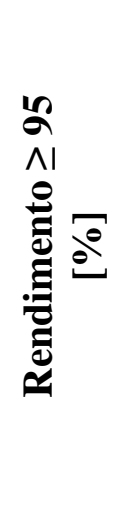 & 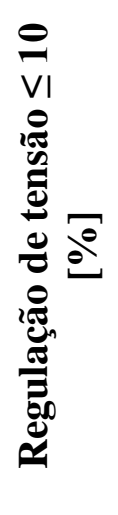 & 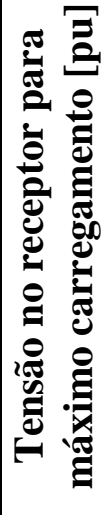 & 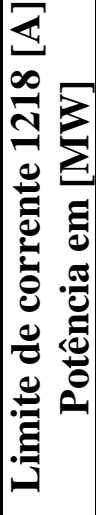 & 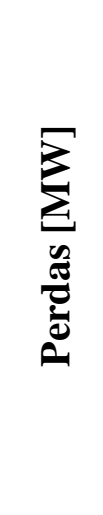 & 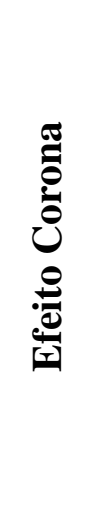 & 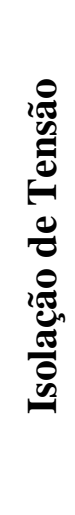 & 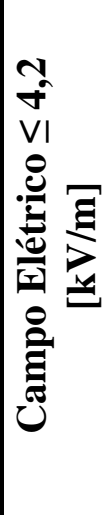 & 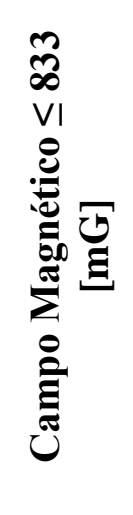 & 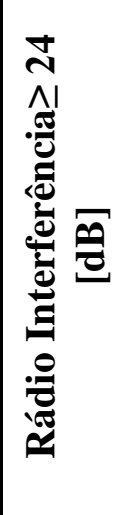 & 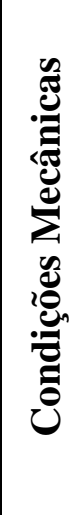 \\
\hline 1 & & & & 600 & & & & & & & \\
\hline 2 & & & $\mathbf{0 , 8 5}$ & 650 & & Jão & Ok & 2,09 & & & OI \\
\hline 3 & 6,89 & 5,58 & 0,85 & 650 & 21,24 & Não & Ok & 2,30 & & & $\overline{\mathrm{Ok}}$ \\
\hline 4 & & 17,65 & 0,84 & 650 & & $\overline{\mathrm{Na}}$ & $\overline{\mathrm{Ok}}$ & 2,12 & & & $\overline{\mathrm{Ok}}$ \\
\hline 5 & 98,50 & & 0,94 & 900 & 1006 & Sim & Ok & 2,68 & 483,57 & & $\mathrm{Ok}$ \\
\hline 6 & & & 0,95 & 920 & & Não & Ok & 3,30 & & & $\overline{\mathrm{Ok}}$ \\
\hline 7 & & & $\mathbf{0 , 9 6}$ & 950 & 4,79 & Não & Ok & 3,34 & & 67,13 & Ok \\
\hline 8 & 99,17 & 4,61 & 0,95 & 950 & 5,51 & Não & Ok & 3,17 & 485,56 & \begin{tabular}{|l|}
71,39 \\
\end{tabular} & Ok \\
\hline
\end{tabular}

Considerando o fator que mais limitou a transmissão de potência na LT, a repotenciação definiu que:

- Pela configuração 2 a LT consegue transmitir 380MW em 345 kV, limitada pelo valor de 0,95 pu de tensão no receptor, em regime permanente e sem compensação de potência reativa.

- Pela configuração 7 a LT consegue transmitir $720 \mathrm{MW}$ em $500 \mathrm{kV}$, pelo valor de 0,95 pu de tensão no receptor, em regime permanente e sem compensação de potência reativa.

\subsection{ANÁLISE DE CURTOS-CIRCUITOS}

Conforme apresentado no quarto capítulo, este procedimento visa analisar as variações das grandezas elétricas ocasionas por faltas na LT, e a identificação de superação da suportabilidade de corrente de curto-circuito simétrica dos disjuntores situados nas extremidades da LT, ou seja, nos barramentos das subestações de Furnas e Poços de Caldas. 
As análises das variações das grandezas serão ilustradas por figuras e tabelas, observando três fatores influentes:

- Nível de tensão das configurações;

- Localização da falta;

- Influência da resistência de falta de 35 ohms na LT.

As análises de superação dos disjuntores serão apresentadas sequencialmente por tabelas, observando as maiores correntes simétricas ocorridas entre todos os tipos e localizações das faltas simuladas.

\subsubsection{Análise da variação das grandezas de corrente e tensão}

Para a análise de curto-circuito desta seção utilizou-se o programa DIgSILENT PowerFactory (DIgSILENT, 2010) . As faltas foram aplicadas nos barramentos das subestações e ao longo da LT, apresentando na sequência uma síntese dos resultados e observações para cada tipo de falta.

Os valores encontrados das grandezas durante as simulações de curto-circuito caracterizados nas figuras são apresentados também através das tabelas disponíveis no Anexo D.

\section{Faltas trifásicas no barramento de Furnas}

A Figura 4-16 mostra as correntes de curto-circuito referentes a simulações de faltas trifásicas no barramento de Furnas, para todas as configurações de repotenciação aplicadas na metodologia apresentada nesta dissertação. Esta figura mostra a corrente de falta no barramento de Furnas para o caso de uma falta franca e também considerando uma resistência de falta de $35 \Omega$ (resistência de falta usual para a LTFUPC1, conforme discussão com técnicos especialistas de sistemas de proteção de Furnas). Além disso, para as duas condições de falta são também mostradas as contribuições provenientes do barramento Poços de Caldas. 
Por esta análise observa-se que as correntes de curto-circuito são maiores para configurações em $345 \mathrm{kV}$, chegando a atingir valores de até $25 \mathrm{kA}$ no barramento de Furnas, enquanto que para configurações de $500 \mathrm{kV}$ a corrente atingiu aproximadamente $19 \mathrm{kA}$ no mesmo barramento. Isto aconteceu porque se admitiu a mesma potência de curto-circuito nos barramentos terminais da LT, para as configurações operativas em $500 \mathrm{kV}$.

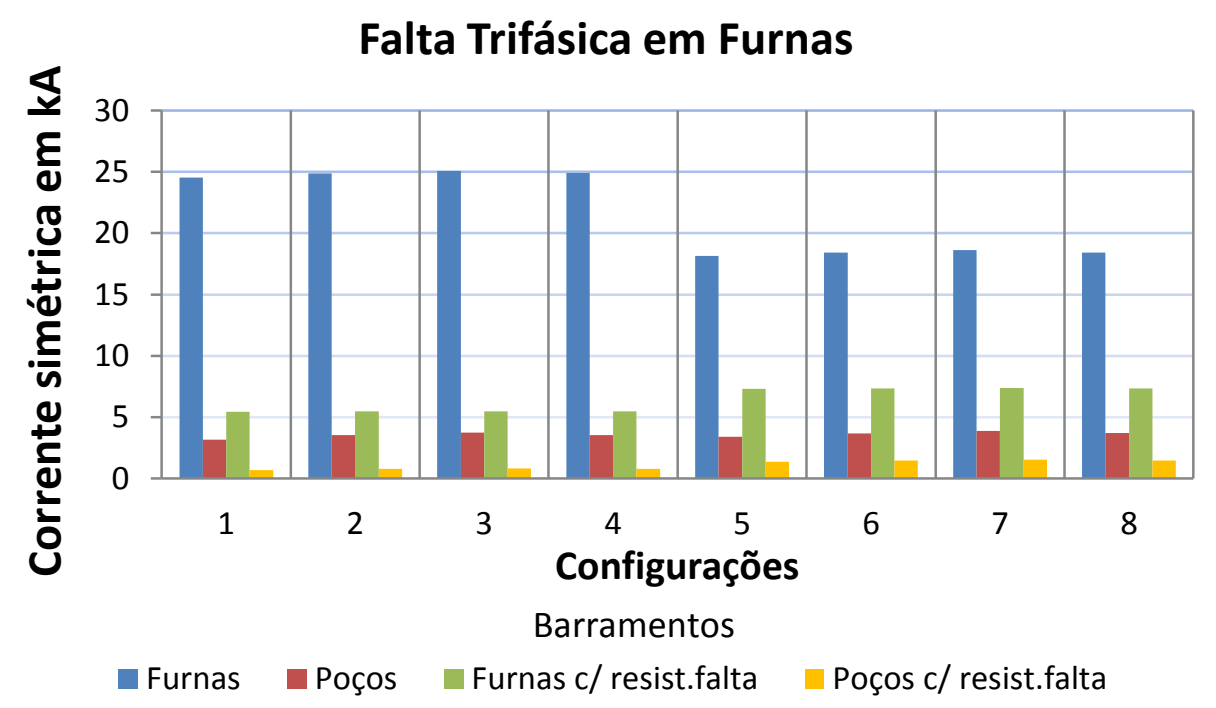

Figura 4-16 - Correntes sob falta trifásica franca no barramento de Furnas

De uma maneira geral, as configurações de repotenciação não influenciaram significativamente as correntes de falta. Um fato interessante pode ser observado quando considerada a resistência de falta de 35 ohms nas simulações. Nesta condição, as correntes encontradas foram ligeiramente maiores para configurações em $500 \mathrm{kV}$ (5 a 8), ou seja, $5 \mathrm{kA}$ para configurações em $345 \mathrm{kV}$, e $7 \mathrm{kA}$ para configurações em $500 \mathrm{kV}$. Isso ocorre porque a resistência de falta tem um valor muito maior que a impedância natural da LT, e figura como o principal fator limitante da corrente de curto-circuito, logo, quanto maior a tensão no barramento, maior será a corrente de falta nas simulações, quando se considera a resistência de falta. Independentemente disso e em relação à superação da capacidade de curto-circuito 
dos disjuntores, deve ser avaliada sempre a pior situação que, neste caso, é considerando resistência de falta nula.

\section{Faltas monofásicas no barramento de Furnas}

As faltas monofásicas foram aplicadas na fase A, no barramento de Furnas. A análise da corrente é feita de acordo com os mesmos parâmetros adotados na falta trifásica, ou seja, relacionando fatores como nível da tensão nominal das configurações, a localidade da falta e a influência da resistência de falta da LT também de 35 ohms.

A Figura 4-17 mostra as correntes de curto-circuito referentes a simulações de faltas fase-terra no barramento de Furnas, para todas as configurações de repotenciação aplicadas na metodologia apresentada nesta dissertação. Esta figura mostra a corrente de falta no barramento de Furnas para o caso de uma falta franca e com resistência de falta de $35 \Omega$. Para as duas condições de falta são também mostradas as contribuições provenientes do barramento Poços de Caldas. De acordo com os resultados, a corrente simétrica de curtocircuito aproxima-se de $23 \mathrm{kA}$ para as configurações em $345 \mathrm{kV}$, enquanto que para configurações em 500 kV o nível de corrente é de aproximadamente 17 kA no barramento de Furnas. Conclui-se que para as configurações que possuem o mesmo nível de tensão, a influência das mesmas na corrente de curto-circuito fase-terra pode ser desprezada. 


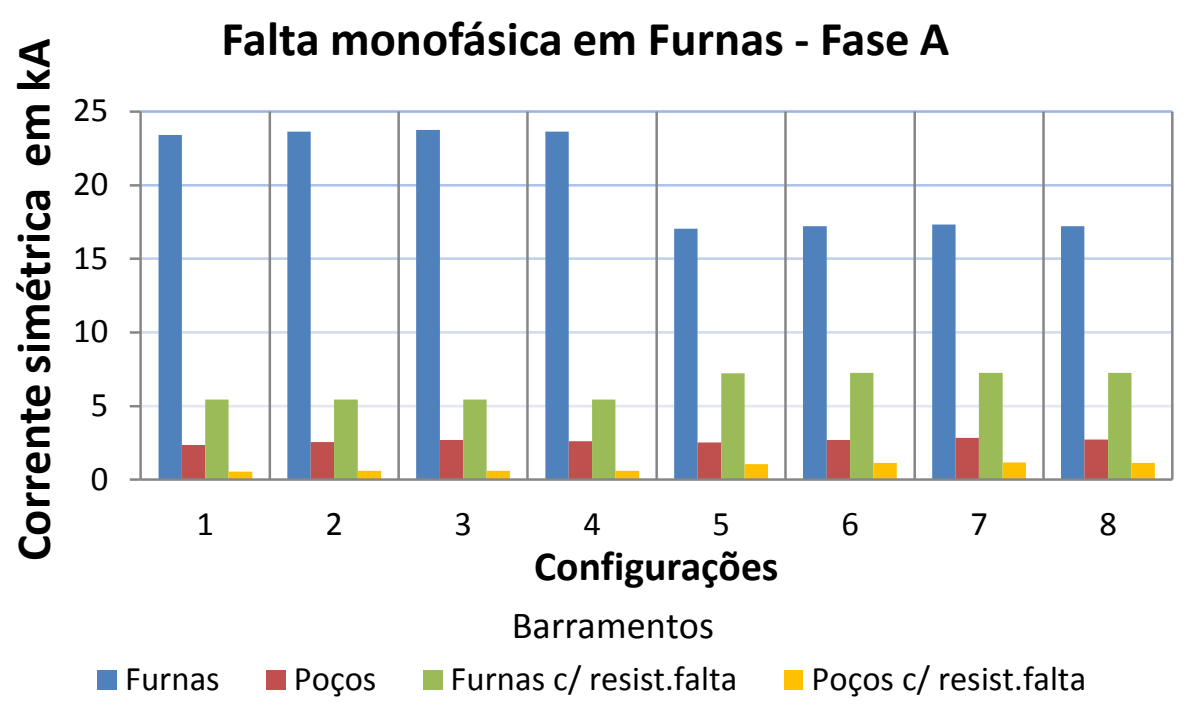

Figura 4-17 - Correntes sob falta monofásica em Furnas

A Figura 4-17 também mostra que quando considerada a resistência de falta na LT, os valores de corrente simétrica são maiores em $500 \mathrm{kV}$ do que em $345 \mathrm{kV}$, pelos mesmos motivos explicados para os casos de faltas trifásicas.

A Figura 4-18 apresenta o comportamento das tensões de fase, com aplicação da falta monofásica em Furnas (fase A), sem considerar a resistência de falta na LT. Observa-se que na fase A, a tensão chegou à zero no local da falta (representada pela cor azul), enquanto ocorre sobretensão nas fases sãs, conforme Stevenson (1974). No entanto, os valores das sobretensões nas demais fases não diferiram significativamente entre as configurações de repotenciação dentro de uma mesma classe tensão. As configurações de repotenciação em 345 $\mathrm{kV}$ (configurações de 1 a 4) apresentaram uma pequena vantagem: a maior sobretensão verificada neste caso foi de $102,4 \%$ da tensão nominal, contra $102,9 \%$ das configurações em $500 \mathrm{kV}($ de 5 a 8$)$. 


\section{Falta monofásica em Furnas - Fase A}

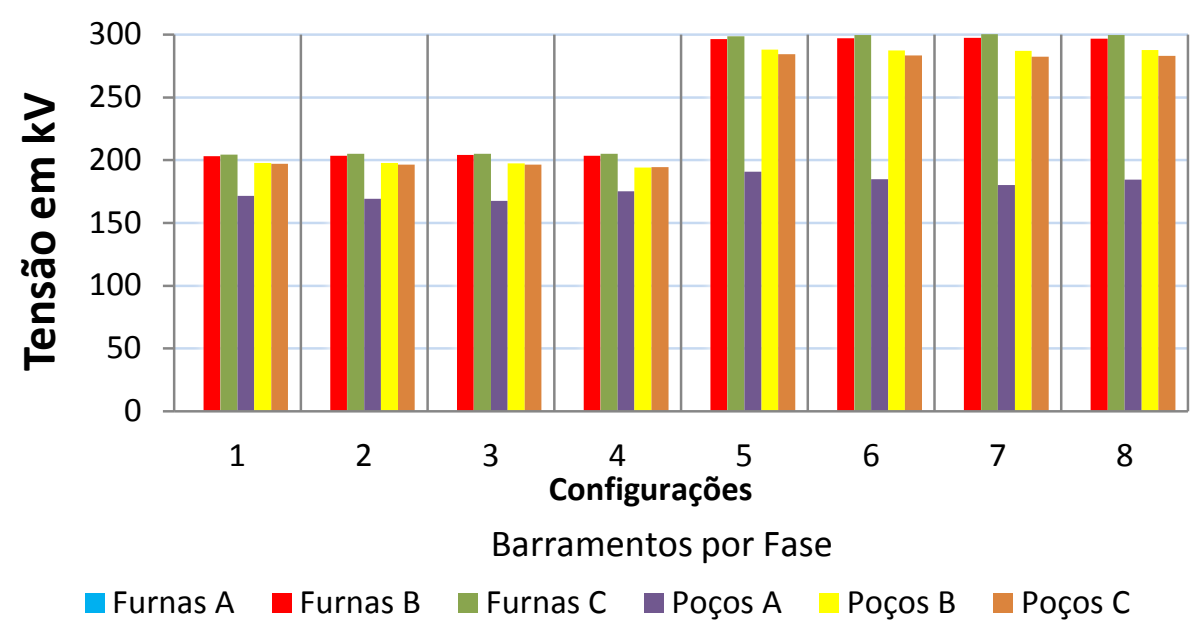

Figura 4-18 - Tensões de fase sob falta monofásica em Furnas.

Com auxílio da Figura 4-19, observa-se quase o mesmo comportamento da tensão em relação à Figura 4-18. A tensão na fase A dessa vez teve um menor afundamento, pois a presença da resistência de falta influi nas componentes simétricas de tensão da fase A. A tensão agora é diferente de zero e contribuiu para diminuir o valor da corrente de curtocircuito, minimizando a queda de tensão e o desequilíbrio entre fases. As sobretensões nas fases sãs também foram menores do que aquelas observadas na Figura 4-18.

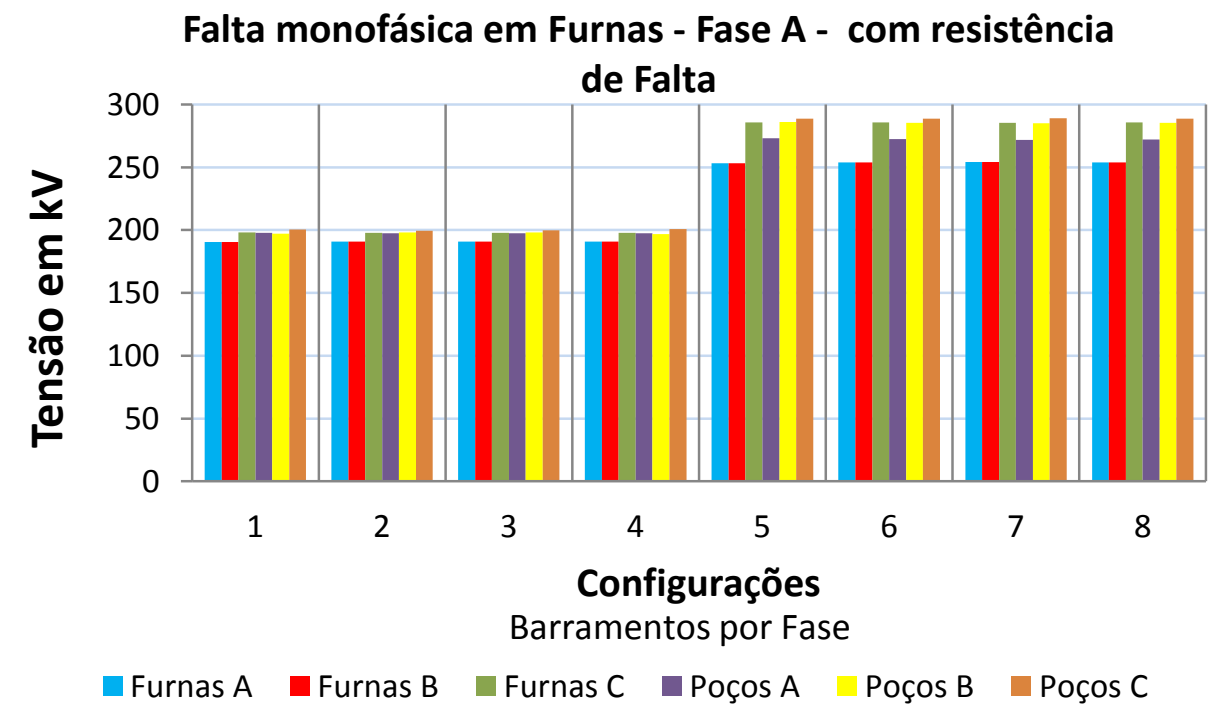

Figura 4-19 - Tensões de fase sob falta monofásica em Furnas, com resistência de falta. 


\section{Faltas trifásicas e monofásicas no barramento de Poços de Caldas}

As simulações de faltas trifásicas e monofásicas no barramento de Poços de Caldas apresentam as mesmas características ocorrentes nas faltas do barramento de Furnas, quando relacionados os parâmetros de nível de tensão nominal da LT, localidade da falta e influência da resistência de falta. Assim, as conclusões são as mesmas. Por este motivo dispensa-se o relato das análises de falta neste barramento, porém os resultados são apresentados por meio das tabelas do Anexo D.

\section{Faltas trifásicas em $50 \%$ da LT (no km 65,5)}

As faltas realizadas no meio da LT são ilustradas pelas figuras seguintes, apresentando as variações das grandezas conforme influência dos fatores já definidos nas simulações anteriores.

A Figura 4-20 mostra os valores da corrente de curto-circuito para uma falta no meio da LT, considerando ou não resistência de falta. Além da corrente medida no ponto de aplicação da falta, são também apresentadas as contribuições de corrente das barras terminais da LT. Analisando a Figura 4-20, as seguintes observações podem ser evidenciadas:

- Dentre as configurações em $345 \mathrm{kV}$ e para os casos de falta franca, a configuração 1 resultou nos menores valores de corrente, enquanto a configuração 3, nos maiores valores. As diferenças entre ambos os casos atingem cerca de $1 \mathrm{kA}$. Isso se deve ao fato de que a configuração 1 ter dois condutores por fase e a 3 apresenta quatro condutores por fase. Consequentemente, a impedância equivalente no ponto de falta é menor neste caso. Para as configurações em $500 \mathrm{kV}$, as observações foram análogas em relação às configurações 5 e 7 , respectivamente. 
- Para os casos com resistência de falta verifica-se que a influência das configurações de repotenciação é desprezível.

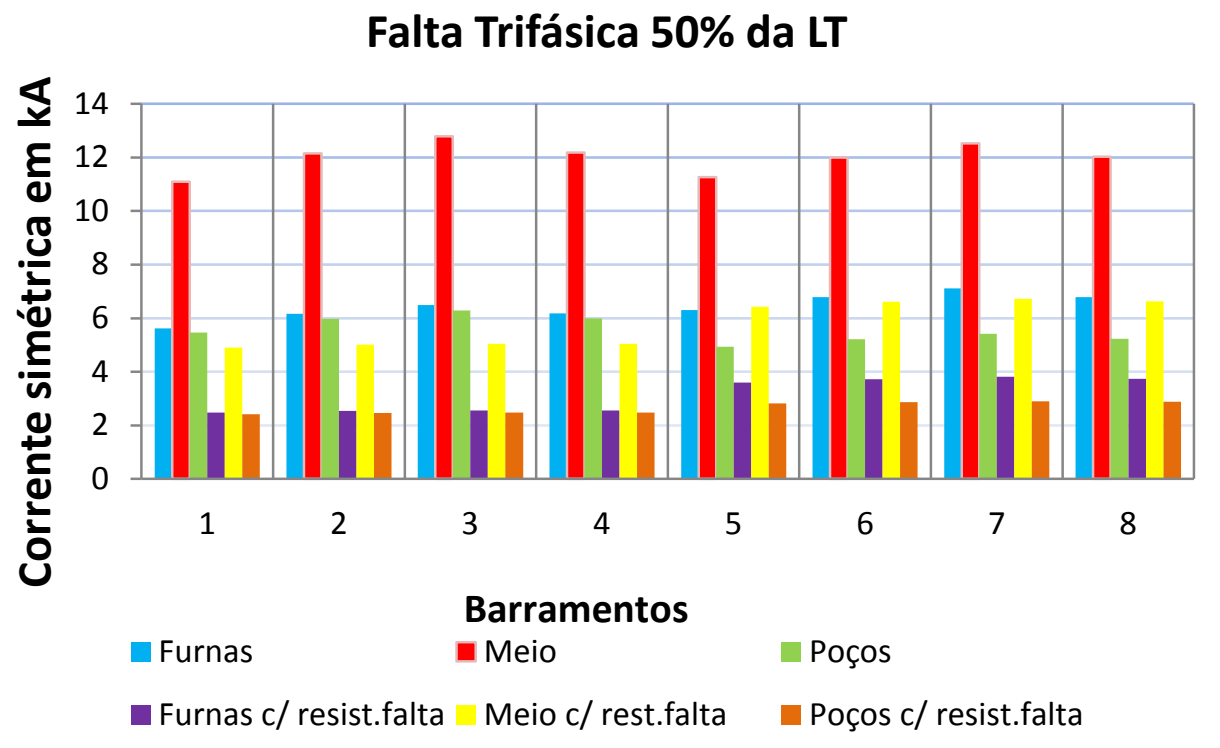

Figura 4-20 - Correntes sob falta frifásica em $50 \%$ da LT.

\section{Faltas monofásicas em $50 \%$ da LT (no km 65,5)}

Seguindo o mesmo procedimento das simulações trifásicas em 50\% da LT, a Figura 4-21 apresenta as correntes de curto-circuito para faltas monofásicas no meio da LT, considerando ou não a resistência de falta. Em relação às faltas francas, observa-se que existe a tendência de a corrente de falta ser maior nas configurações com três ou quatro condutores por fase, independente do nível de tensão. Para as configurações na classe de 345 kV, a maior corrente foi verificada para a configuração 4 , diferente do que ocorre para o caso de falta trifásica apresentada na Figura 4-20. Por outro lado, considerando as configurações da classe de 500 kV, o resultado foi coerente com o observado na Figura 4-20, ou seja, a configuração que ocasionou a maior corrente foi a de número 7. Finalmente, os casos de curto-circuito monofásico com resistência de falta não apresentaram diferenças significativas entre as configurações dentro de uma mesma classe de tensão. 


\section{Falta monofásica em $\mathbf{5 0 \%}$ da LT}

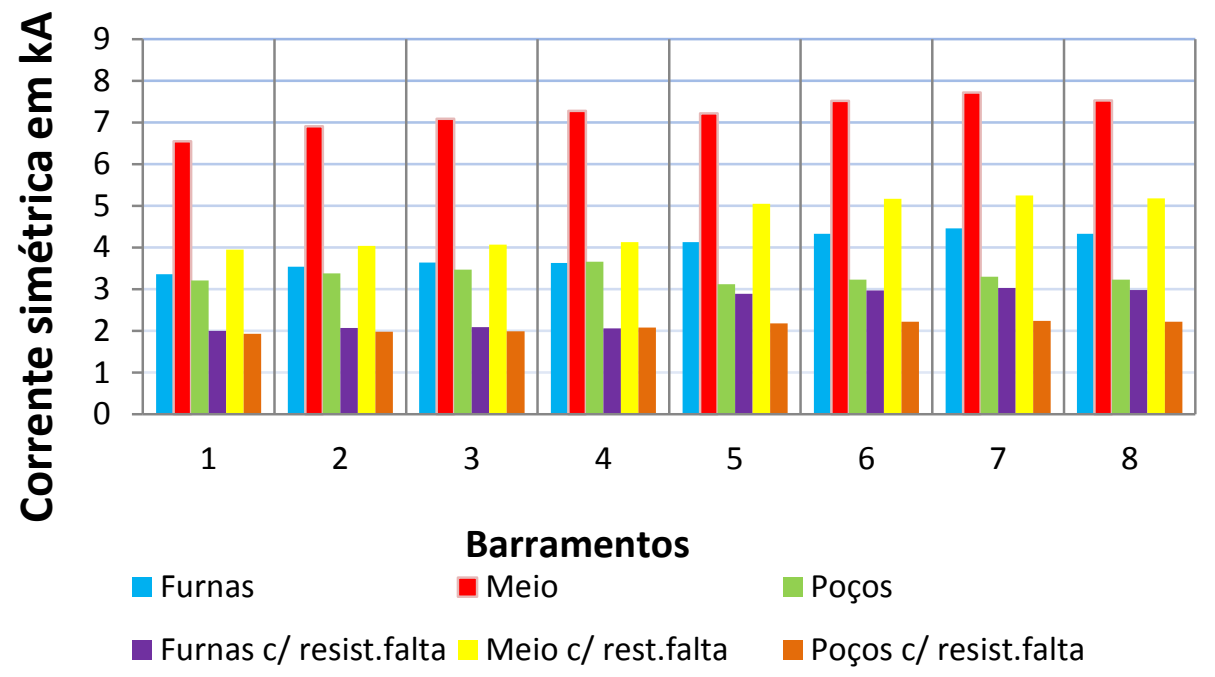

Figura 4-21 - Correntes sob falta monofásica em 50\% da LT.

Em relação à sobretensões causadas pelas faltas fase-terra, a Figura 4-22 mostra as tensões de fase em cada barra terminal da LT. Observa-se que as sobretensões nas fases sãs não são severas, pois atingem valores da mesma ordem de grandeza da tensão nominal de fase. Além disso, observa-se que não existem diferenças significativas entre as configurações de uma mesma classe de tensão.

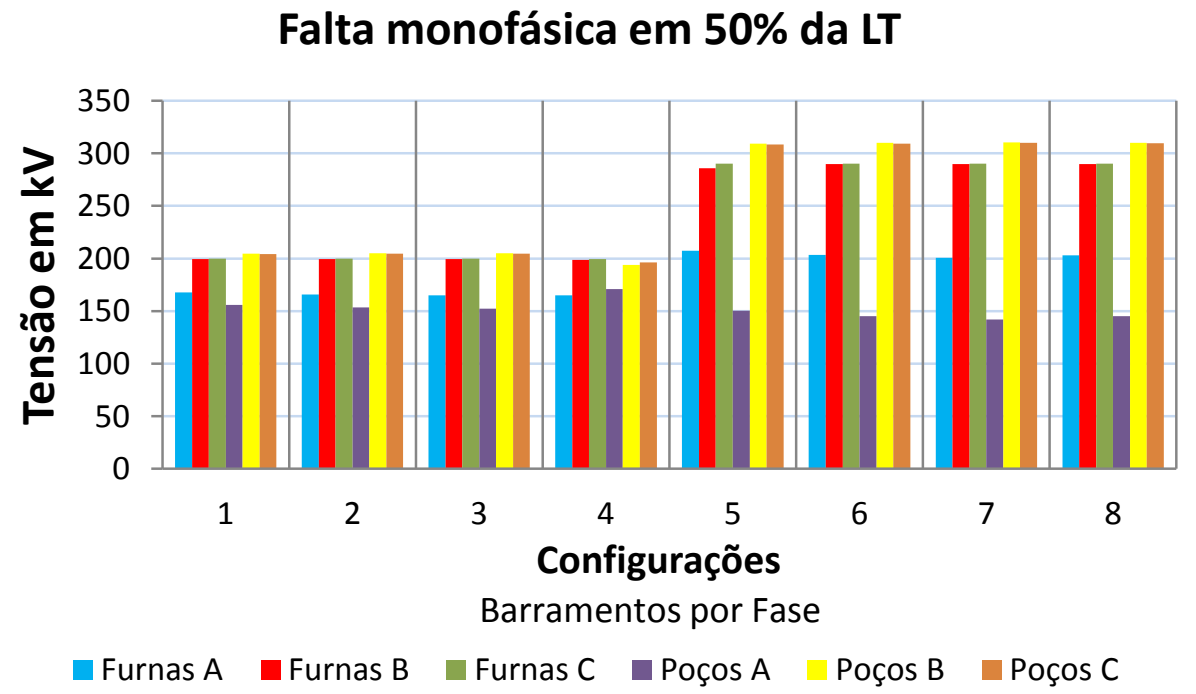

Figura 4-22 - Tensões de fase sob falta monofásica em 50\% da LT. 
Para finalizar esta análise, a Figura 4-23 apresenta as tensões de fase nas barras terminais da LT, para um curto-circuito monofásico com resistência de falta na metade da mesma. De maneira análoga aos resultados apresentados na Figura 4-22, as diferentes configurações não causam impactos significativos na corrente de falta e nas tensões de fase.

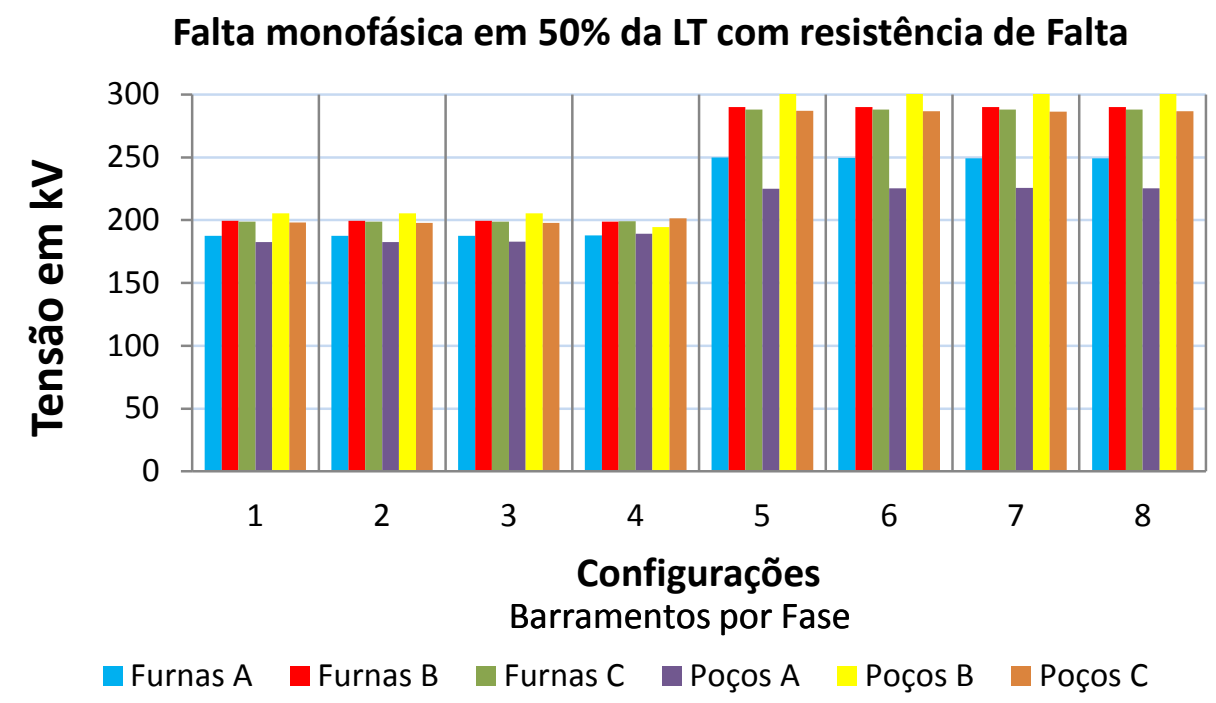

Figura 4-23 - Tensões de fase sob falta monofásica em $50 \%$ da LT, com resistência de falta na LT

\subsubsection{Análise de suportabilidade dos disjuntores}

A análise a seguir representa a situação dos disjuntores frente às faltas que proporcionaram os maiores valores de corrente simétrica, conforme a localidade da falta.

O critério adotado para esta análise segue conforme ONS (2011).

- O disjuntor cuja relação entre corrente de curto-circuito e a capacidade de interrupção simétrica apresentar valores iguais ou superiores a 100\%, será considerado como SUPERADO;

- Se a relação apresentar valores superiores a 90\% e inferiores a $100 \%$, será considerado como em estado de ALERTA e;

- Se a relação estiver abaixo de $90 \%$ será considerado OK. 
A Tabela 4-11 representa as máximas correntes simétricas de curto-circuito obtidas para as faltas monofásicas e trifásicas simuladas no barramento de Furnas, considerando todas as configurações de repotenciação. Nesta tabela, tem-se:

$$
\begin{aligned}
& \text { ICCS = capacidade de interrupção simétrica do disjuntor } \\
& \text { ICC = corrente de curto-circuito pelo disjuntor } \\
& \text { SCC = potência de curto-circuito } \\
& 1 \mathrm{~F}=\text { curto-circuito monofásico } \\
& 3 \mathrm{~F}=\text { curto-circuito trifásico }
\end{aligned}
$$

O disjuntor instalado no barramento de Furnas possui seu limite de corrente simétrica em 22 kA. Observa-se que para todas as configurações com tensão em 345 kV o disjuntor já se encontra superado tanto para faltas trifásicas quanto monofásicas. As análises indicam que o disjuntor já deveria ser substituído por outro de maior capacidade de interrupção simétrica. Esta conclusão é correta, pois segundo o banco de dados do ONS, este disjuntor também já é considerado superado com aproximadamente $120 \%$.

Para as configurações em $500 \mathrm{kV}$, os limites de corrente simétricas não foram atingidos, tanto para faltas trifásicas, quanto para monofásicas, garantindo a conformidade de operação do disjuntor.

Tabela 4-11 - Suportabilidade do disjuntor do barramento de Furnas

\begin{tabular}{|c|c|c|c|r|r|c|}
\hline \multicolumn{7}{|c|}{ Disjuntor Barramento de Furnas - Falta Furnas } \\
\hline \multirow{2}{*}{ Configuração } & \multirow{2}{*}{$\begin{array}{l}\text { ICCS } \\
(\mathrm{kA})\end{array}$} & \multicolumn{2}{|c|}{$\begin{array}{c}\text { ICC } \\
(\mathrm{kA})\end{array}$} & \multicolumn{2}{c|}{$\begin{array}{c}\text { ICC/ICCS } \\
(\%)\end{array}$} & \multirow{2}{*}{ Situação } \\
\cline { 3 - 7 } & 22 & 23,42 & 24,52 & 106,45 & 111,45 & Superado \\
\hline 1 & 22 & 23,63 & 24,88 & 107,40 & 113,09 & Superado \\
\hline 2 & 22 & 23,76 & 25,09 & 108,00 & 114,04 & Superado \\
\hline 3 & 22 & 23,65 & 24,89 & 107,50 & 113,13 & Superado \\
\hline 4 & 22 & 17,06 & 18,14 & 77,54 & 82,45 & OK \\
\hline 5 & 22 & 17,22 & 18,41 & 78,27 & 83,68 & OK \\
\hline 6 & 22 & 17,34 & 18,61 & 78,81 & 84,59 & OK \\
\hline 7 & 22 & 17,23 & 18,42 & 78,31 & 83,72 & OK \\
\hline 8 & & & & & & \\
\hline
\end{tabular}


Para o disjuntor do barramento de Poços de Caldas, as faltas simuladas neste mesmo barramento foram as que resultaram em maiores correntes simétricas. O disjuntor também tem seu limite de corrente simétrica em $22 \mathrm{kA}$. A Tabela 4-12 ilustra que as faltas trifásicas foram responsáveis pelas maiores correntes, para todas as configurações propostas. As configurações de 1 a $4(345 \mathrm{kV})$ tiveram o limite do disjuntor superado para faltas monofásicas e trifásicas, indicando a necessidade de substituição do disjuntor. Esta conclusão é aproximada com o banco de dados da ONS, que considera este disjuntor superado, com 120\%, para a configuração 1 (original da LT). Uma pequena diferença entre a condição real e as simulações propostas é esperada devido às diferenças na modelagem da LT, programas adotados e relações $\mathrm{X} / \mathrm{R}$ aproximadas. As configurações de 5 a $8(500 \mathrm{kV})$ mantiveram os valores de corrente simétrica abaixo do limite de superação, garantindo a conformidade do disjuntor.

Tabela 4-12 - Suportabilidade do disjuntor do barramento de Poços de Caldas

\begin{tabular}{|c|c|c|c|r|r|c|}
\hline \multicolumn{5}{|c|}{ Disjuntor Barramento de Poços de Caldas - Falta Poços de Caldas } \\
\hline \multirow{3}{*}{ Configuração } & \multirow{2}{*}{$\begin{array}{c}\text { ICCS } \\
(\mathrm{kA})\end{array}$} & \multicolumn{2}{|c|}{$\begin{array}{l}\text { ICC } \\
(\mathrm{kA})\end{array}$} & \multicolumn{2}{|c|}{$\begin{array}{c}\text { ICC/ICCS } \\
(\%)\end{array}$} & \multirow{2}{*}{ Situação } \\
\cline { 3 - 7 } & & $1 \mathrm{~F}$ & $3 \mathrm{~F}$ & \multicolumn{1}{c|}{$1 \mathrm{~F}$} & $3 \mathrm{~F}$ & \\
\hline 1 & 22 & 16,55 & 22,6 & 75,22 & 102,72 & Superado \\
\hline 2 & 22 & 16,71 & 22,96 & 75,95 & 104,36 & Superado \\
\hline 3 & 22 & 16,79 & 23,19 & 76,31 & 105,40 & Superado \\
\hline 4 & 22 & 16,71 & 22,98 & 75,95 & 104,45 & Superado \\
\hline 5 & 22 & 8,83 & 12,96 & 40,13 & 58,90 & OK \\
\hline 6 & 22 & 8,98 & 13,35 & 40,81 & 60,68 & OK \\
\hline 7 & 22 & 9,09 & 13,63 & 41,31 & 61,95 & OK \\
\hline 8 & 22 & 8,99 & 13,36 & 40,86 & 60,72 & OK \\
\hline
\end{tabular}

\subsection{CONSIDERAÇÕES FINAIS DO CAPÍTULO}

As análises apresentadas neste capítulo mostraram que os fatores de desempenho e os IMA propostos, são eficientes para avaliar diferentes técnicas de repotenciação de LTs sob o ponto de vista de regime permanente. De todos os aspectos analisados, o campo magnético da LT e a ocorrência de curtos-circuitos não se mostraram efetivos para avaliar o desempenho 
de diferentes técnicas de repotenciação. Em relação aos curtos-circuitos, de maneira geral observou-se que as configurações com o maior número de condutores por fase resultaram em maiores níveis de corrente de falta, em relação ao caso base. Contudo, este aumento não foi significativo para as condições analisadas e pode-se afirmar que o desempenho das técnicas de repotenciação frente às correntes de curto-circuito não é um fator decisivo para selecionar a melhor técnica. 


\section{Capítulo 5}

\section{Conclusões}

As análises deste trabalho permitiram que o objetivo inicialmente proposto fosse atingido, sendo identificada a melhor técnica a ser utilizada para a repotenciação de uma LT, por meio da metodologia proposta.

Através da metodologia proposta, obteve-se uma gama de informações por meio das simulações e cálculos, possibilitando identificar com clareza as respostas mais eficientes em termos de transmissão de energia elétrica, considerando todas as configurações aplicadas na repotenciação da $\mathrm{LT}$.

Ressalta-se que os fatores de desempenho e os índices de mérito agregado (IMA), foram os principais responsáveis para o sucesso da metodologia, considerando ainda sua adequação às normas operativas vigentes.

O conteúdo do trabalho proposto permite ainda destacar sua aplicação em quaisquer linhas de transmissão passíveis de repotenciação, sendo esta aplicação responsável pela agilidade em tais processos de aumento de potência transmitida. O trabalho pode ainda servir como relatório inicial para estudos de LTs, não só na repotenciação, mas também quando se busca comparação de valores de transmissão de potência e adequação aos índices e limites normativos.

A aplicação da metodologia de análise na LT sob estudo, considerando as sete técnicas de repotenciação, permitiu uma avaliação extensiva do desempenho da mesma sob diversos aspectos relevantes para a operação de uma LT em regime permanente. As curvas de rendimento, regulação de tensão, capacidade de condução de corrente, PV e de perdas por efeito Joule permitem uma avaliação para diferentes pontos de operação da LT repotenciada. 
Dentro desses procedimentos, observou-se que as técnicas de repotenciação que mais se destacaram foram a configuração 2, em $345 \mathrm{kV}$, e a configuração 7, em $500 \mathrm{kV}$. Os resultados mostraram que nem sempre o lançamento de mais um condutor por fase traz vantagens, como pôde ser notado em relação às configurações 2 e 4, em 345 kV. Neste caso, o desempenho de ambas foi muito parecido, com uma ligeira vantagem da configuração 2. Os IMA propostos resultaram nas mesmas conclusões da análise dos gráficos de rendimento, regulação de tensão e das curvas PV. Assim, quando se deseja executar estudos de repotenciação visando apenas o carregamento da LT, a utilização dos IMA pode ser adotada individualmente, tornando o processo de análise mais rápido.

A análise dos fatores de perdas por efeito Corona, rádio interferência e influência de campos elétricos e magnéticos também mostraram uma predominância das técnicas representadas pelas configurações 2 e 7. Elas não apresentaram o melhor desempenho em todos esses fatores, porém não provocaram qualquer violação de limites permissíveis.

Finalmente, da análise de sete técnicas de repotenciação foi possível selecionar duas delas, a configuração 2 e a configuração 7.

A análise de curtos-circuitos efetuada na dissertação como avaliação complementar, permitiu identificar o comportamento das correntes e tensões da LT, perante todas as configurações de repotenciação utilizadas. A principal ocorrência desta análise manifestou-se nas configurações $1,2,3$ e $4(345 \mathrm{kV})$, onde houve a superação do limite de corrente simétrica dos disjuntores alocados nos terminais da LT. Esta ocorrência apontou a substituição destes disjuntores como uma ação necessária, no processo de repotenciação da LT para as configurações apontadas. Além disso, mostrou-se que a magnitude das correntes de curto-circuito e as sobretensões originadas a partir de faltas monofásicos não são parâmetros suficientes para distinguir as técnicas de repotenciação, uma vez que o desempenho foi muito parecido entre todas as configurações. Em alguns casos, as correntes de 
falta das configurações em $500 \mathrm{kV}$ foram inferiores àquelas das configurações em $345 \mathrm{kV}$. Esta característica evidencia a única vantagem das configurações em $500 \mathrm{kV}$ em relação às correntes de curto-circuito.

A metodologia apresentada nesta dissertação não permite apontar que uma técnica de repotenciação seja considerada a mais econômica dentre as demais apresentadas. Esta afirmação deve-se ao fato de que cada técnica de repotenciação de LT possui características particulares. O custo da repotenciação normalmente é calculado em função do peso do cabo utilizado no comprimento da LT, porém, outros fatores devem ser considerados, tais como: custos de estudos do projeto de repotenciação, transporte dos materiais, reparações pontuais que podem não ser detectadas previamente nas estruturas da LT, mão-de-obra especializada, dentre outros. A análise econômica deve considerar fatores que determinam a viabilidade da repotenciação. Os fatores devem considerar a posição geográfica em que a LT está inserida no sistema elétrico, a disponibilidade de transmissão de potência, seja ela em caráter de emergência, em curto ou longo prazo.

Perante as considerações sobre a avaliação econômica espera-se que o proprietário da LT identifique seus principais objetivos com a repotenciação. Tendo em vista a viabilidade da repotenciação, impulsionada por critérios de investimento ou necessidade técnica operacional, a repotenciação deve concentrar parâmetros como:

- Eficiência na transmissão, com redução de perdas;

- Inserção de ganhos em energia e potência no mercado;

- Otimização de procedimentos operacionais e de recursos;

- Incorporação aos projetos de repotenciação, modernizações como automação de comandos, digitalização dos equipamentos e utilização de programas computacionais;

- Redução de custos operacionais; 
- Menor paralisação da transmissão.

A pesquisa apresentada nesta dissertação permite sugerir como continuidade a criação de um programa computacional que abranja as simulações de fluxo de carga, e que incorpore os fatores e índices sugeridos para a identificação automática da melhor técnica de uma maneira mais robusta.

A simulação da LT em condições de transitórios eletromagnéticos de chaveamentos, energizações e descargas atmosféricas, também são estudos de valia para considerações em uma LT repotenciada, completando todos os fenômenos apresentados em uma LT. 


\section{Referências Bibliográficas}

AMARAL, A. C. S., FERNANDES, D. Carregamentos e Fatores de Segurança Mecânicos Adotados nos Projetos das Linhas de Transmissão de 345 e 500 kV de Furnas. Rio de Janeiro: Abril, 1976.

ANEEL (2001). Conformidade dos níveis de tensão de energia elétrica em regime permanente. Resolução da ANEEL n505, de 26 de novembro de 2001.

ASCE (1988). Guide for designer of steel transmission towers. Asce Manuals and Reports on Enginheering Practice. No 52, New York.

BARBOSA, C. R. N., MPALANTINOS, A. N., DOMINGUES, L. A. M. C., SILVA, J. I. F., ANDRADE, V. H. G., AMORIM, H. P. J., OLIVEIRA, P. R. G., AMON, J. F., PIMENTA, D. G. (2007). Desenvolvimento e Aplicação de Metodologias para Análise do Desempenho de Linhas de Transmissão. In: XIX Seminário Nacional de Produção de Transmissão de Energia Elétrica (XIX SNPTEE), Rio de Janeiro: 8 p.

BEZERRA, J. M. B. (1998). Limites de Carregamento de Linhas de Transmissão. Definição e Expansão. Apostila de Curso de Extensão Universitária, ministrado a engenheiros de empresas conveniadas do CCON em 1998.

BIASOTTO, E. Um procedimento de análise para a repotenciação de linhas de subtransmissão de $\mathbf{3 4 , 5}$ kV para 69 kV. 2009. 130 f. Dissertação (Mestrado em Engenharia Elétrica) - Departamento de Engenharia Elétrica, EESC, USP, São Carlos, 2009.

CAMPEM, "Campos Elétricos e Magnéticos", V1.0, CEPEL - Centro de Pesquisas de Energia Elétrica. Dezembro, 2004. Sítio:〈http://www.cepel.br/>.

CAMPO, "Campo Elétrico superficial do condutor", V1.0, CEPEL - Centro de Pesquisas de Energia Elétrica. Dezembro, 2004. Sítio:〈http://www.cepel.br/>. 
CAVASSIN, R. S e FERNANDES, T. S. P. (2012). Uma abordagem multicritérios para recapacitação de linhas de transmissão. Sba Controle \& Automação, vol.23, n.6, pp. 749-765.

DA COSTA, E. C. M. Um modelo para condutores múltiplos considerando a distribuição da corrente nos condutores. 2009. 98 f. Dissertação (Mestrado em Engenharia Elétrica) Faculdade de Engenharia de Ilha Solteira, UNESP, Ilha Solteira, 2009.

DIgSILENT GmbH, "DIgSILENT PowerFactory V13.2 - Users Manual", DIgSILENT GmbH, Gomaringen, Germany 2010.

DOMINGUES, L. A. M. C., FERNANDES C., BARBOSA, C. R. N., DART, F. C. (2000). Cálculo de campo elétrico pelo método de simulação de cargas. Relatório CEPEL 923/95, 2000.

DOMingues, L. A. M. C., CAMARGO, GeORGE. BARBOSA, C. R. N. (2005). Avaliação do desempenho de linhas de transmissão: Cálculo do campo elétrico superficial em condutores - programa CAMPO. Relatório Técnico DIE 44913/05, 2005.

ESZTERGALYOS, J. Single phase tripping and auto reclosing of transmission lines. IEEE Transactions on Power Delivery, vol 7, n. 1, p. 182-192, Jan. 1992.

FUCHS, R. D. Projetos mecânicos das linhas aéreas de transmissão. São Paulo: Edição Edgard Blucher; Itajubá, Escola Federal de Engenharia, 1982.

FUCHS, R. D. Transmissão de Energia Elétrica: Linhas Aéreas. Teoria das linhas em regime permanente. Livros Técnicos e Científicos; Itajubá, Escola Federal de Engenharia, Vol. 1, 1977.

FUCHS, R. D. Transmissão de Energia Elétrica: Linhas Aéreas. Teoria das linhas em regime permanente. Rio de Janeiro, Livros Técnicos e Científicos; Itajubá, Escola Federal de Engenharia, Vol. 2, 1979. 
FURNAS. Noções de linhas de transmissão. Centro de Treinamento de Furnas (CTFU). Apostila de Treinamento, Furnas, 2000. 110 p.

FURNAS. Instrução de operação - Sobrecarga em equipamentos do sistema de Furnas: Instrução geral 105, revisão 4, CTOS.O, Rio de Janeiro, 2009. 7 p.

GABAGlia, C. P. R., OliveirA, C. F., DART, F. C., ESMERAldO, P. C. V., MPLANTINOS, A. N. (2001). Utilização do Conceito de Feixe Expandido para Recapacitação de Linhas de Transmissão de 500 KV de Furnas. In: XVI Seminário Nacional de Produção de Transmissão de Energia Elétrica (XVI SNPTEE), Campinas: 5 p.

GIUDICE, E. B. F. (2001). Ambiente eletromagnético próximo a linhas aéreas de 500 kV

- Projetos e Impactos. In Artigo apresentado no curso de pós-graduação em engenharia elétrica (CPDEE), com suporte do Departamento de Engenharia de Linhas de transmissão da CEMIG- ER/LT. UFMG, Belo Horizonte, 2001. 11 p.

IEC 60826 (2003). Internacional Electrotechnical Commission. Design criteria of overhead transmissions lines, Ed.3.0, p. 243, Switzerland, 2003.

KUNDUR, P. Power System Stability and Control. New York: McGraw-Hill, 1994.

NBR 5422 (1985). ASSOCIAÇÃO BRASILEIRA DE NORMAS TÉCNICAS. NBR 5422: Projeto de linhas aéreas de transmissão - procedimentos. Fevereiro de 1985.

NBR 8850 (1985). ASSOCIAÇÃO BRASILEIRA DE NORMAS TÉCNICAS. NBR 8850: Execução de suportes metálicos treliçados para linhas de transmissão procedimentos. Fevereiro de 1985.

OLIVEIRA, C. M. F. Recapacitação de linhas de transmissão. 2000. 112 f. Dissertação (Mestrado em Engenharia Elétrica) - Pontifícia Universidade Católica do Rio de Janeiro, Rio de Janeiro, 2000.

ONS (2000). Procedimentos de Rede. Requisitos mínimos para linhas de transmissão aéreas. ONS - Operador Nacional do Sistema Elétrico, Submódulo 2.4. Disponível em: 
<http://www.ons.org.br/download/procedimentos/modulos/Modulo_2/Submodulo\%202.4_ Rev_1.0.pdf>. Acesso em: 27 jan. 2010.

ONS (2009). Estudos de Curto-Circuito. Relações dos níveis de curto circuito trifásicos e monofásicos. Disponível em:<http://www.ons.org.br/operacao/>. Acesso em: 13 jan 2010. ONS (2011). Estudos de Curto-circuito - Volume1. Avaliação dos níveis de curto-circuito, identificação de barras do Sistema Interligado Nacional com possíveis problemas de superação de disjuntores e evolução dos níveis de curto-circuito. Disponível em: $<$ http://www.ons.org.br/operacao/base_dados_curtoc_referencia.aspx >.Acesso em: 20 out 2011.

PLS-CADD (Power Line Systems - Computer Aided Design and Drafting)", Estados Unidos da América, 2006. Disponível em: <http://www.powline.com/products/pls_caddespanol.html>.

PINTO, R. L. F., DOMINGUES, L. A. M. C., BARBOSA, C. R. N. (2005). Avaliação do desempenho de linhas de transmissão: cálculo de campos elétricos, magnéticos e induções - programa CAMPEM. Relatório Técnico DIE - 44914/05, 2005.

SILVA, R. P. e BAUMANN, C. A. G. (1997). Repotenciação de linhas de transmissão: Avaliação de novas tecnologias e concepções. In: XIV Seminário Nacional de Produção de Transmissão de Energia Elétrica (XIV SNPTEE), Belém: 6 p.

Silva, A. O., GABAGliA, C. P. R., N. H. C., NOGUEIRA., AlENCASTRO, A. F. D (2001). Recapacitação de LTs de 138 kV: A experiência de Furnas. In: XVI Seminário Nacional de Produção de Transmissão de Energia Elétrica (XVI SNPTEE), Campinas, 6p. STEPHAN, J. C. S. e COSTA, C. F. (2007). Recapacitação, Repotenciação e Avaliação da Capacidade de Carga de Suportes e Fundações de Linhas Aéreas de Transmissão, Segurança e Confiabilidade. In: XIX Seminário Nacional de Produção de Transmissão de Energia Elétrica (XIX SNPTEE), Rio de Janeiro, 8 p. 
SteVEnson, W. D. JR. Elementos de Análise de Sistemas de Potência. São Paulo:

McGraw-Hill do Brasil, (Rio de Janeiro). Fundação Nacional de Material Escolar, 1974, 1978 reimpressão.

WIEDMER, R. S., HONORATO, O. S. JR., VINÍCIUS, P. S., HOFFMANN, J. N. (2007).

Recapacitação de Linhas de Transmissão 138 kV Utilizando Cabo de Alumínio Liga 6201. In: XIX Seminário Nacional de Produção de Transmissão de Energia Elétrica (XIX SNPTEE), Rio de Janeiro: 8 p. 
ANEXO A

Dados da LT Furnas - Poços de Caldas 
Os dados da linha de transmissão Furnas - Poços de Caldas (LTFUPC1) utilizada neste trabalho são apresentados na Tabela A-1. 
Tabela A-1 - Banco de dados da LTFUPC1

\section{Banco de Dados da Linha de Transmissão}

\begin{tabular}{|c|c|c|c|c|c|}
\hline \multicolumn{6}{|c|}{ Banco de Dados da Linha de Transmissão } \\
\hline \multicolumn{2}{|c|}{ Dados Posicionais } & \multicolumn{4}{|c|}{ Para-raios } \\
\hline Código ONS & LTFUPC1 & Tipo & \multicolumn{3}{|c|}{$\mathrm{ACO}$} \\
\hline Localização & LT Furnas-Poços de Caldas 1 & Bitola & \multicolumn{3}{|c|}{$3 / 8 \mathrm{pol}$} \\
\hline Situação & Operação & Nome & \multicolumn{3}{|c|}{ EHS } \\
\hline Data de Energização & 03/09/1963 & Forma Al/Ac & \multicolumn{3}{|c|}{7} \\
\hline Proprietária & Furnas Centrais Elétricas S.A & Diâmetro $(\mathrm{mm})$ & \multicolumn{3}{|c|}{9.53} \\
\hline \multicolumn{2}{|c|}{ Dados Gerais e Específicos } & Seção Total (mm2) & \multicolumn{3}{|c|}{50.99} \\
\hline Tensão Nominal & $345 \mathrm{kV}$ & Peso $(\mathrm{kg} / \mathrm{km})$ & \multicolumn{3}{|c|}{406} \\
\hline Comprimento $(\mathrm{km})$ & 131 & \multicolumn{4}{|c|}{ Condutores } \\
\hline Sistema & A - Sistema Corrente Alternada & Tipo & \multicolumn{3}{|c|}{ ACSR } \\
\hline Número de condutores na Fase & 2 & Bitola & \multicolumn{3}{|c|}{ 795.0 MCM } \\
\hline Distância mínima entre condutor/terra $(\mathrm{m})$ & 8 & Nome & \multicolumn{3}{|c|}{ DRAKE } \\
\hline Distância entre fases $(\mathrm{m})$ & 10.6 & Forma Al/Ac & \multicolumn{3}{|c|}{$26 / 07$} \\
\hline Ancoragem & 48 & Diâmetro $(\mathrm{mm})$ & \multicolumn{3}{|c|}{28.12} \\
\hline Número de isoladores na cadeia & 20 & Seção Total (mm2) & \multicolumn{3}{|c|}{468.42} \\
\hline Configuração da Cadeia de isoladores & I- Simples para todas fases (III) & Seção Al (mm2) & \multicolumn{3}{|c|}{402.83} \\
\hline Disposição das Fases & $\mathrm{H}$ - Horizontal & Peso $(\mathrm{kg} / \mathrm{km})$ & \multicolumn{3}{|c|}{1628.4} \\
\hline Tipo de Circuito & S - Simples & Ampacidade com sol/sem vento $(A)$ & \multicolumn{3}{|c|}{650} \\
\hline Comprimento das Cadeias de Suspensão $(\mathrm{m})$ & 3.5 & Resistência DC (ohms/km) & \multicolumn{3}{|c|}{0.07192} \\
\hline Peso das Cadeias de Suspensão $(\mathrm{kg})$ & 117.6 & $\mathrm{RMG}(\mathrm{mm})$ & \multicolumn{3}{|c|}{11.36} \\
\hline Comprimento das Cadeias de Ancoragem (m) & 4.1 & \multicolumn{4}{|c|}{ Capacidade de Corrente da LT } \\
\hline Peso das Cadeias de Ancoragem (kg) & 255.2 & \multirow[b]{2}{*}{ Capacidade de Corrente Normal (A) } & com sol & sem sol & Temp. $\left({ }^{\circ} \mathrm{C}\right)$ \\
\hline Tipo de Torres & Autoportante & & 1218 & 1576 & 50 \\
\hline Material construtivo das torres & Estrutura Metálica & \multirow[b]{2}{*}{ Capacidade de Corrente Emergência (A) } & com sol & sem sol & Temp. $\left({ }^{\circ} \mathrm{C}\right)$ \\
\hline Velocidade de Vento de Projeto $(\mathrm{km} / \mathrm{h})$ & 116 & & 1734 & 1984 & 80 \\
\hline \multicolumn{2}{|c|}{ Isoladores dos Condutores } & Temperatura de Projeto $\left({ }^{\circ} \mathrm{C}\right)$ & \multicolumn{3}{|c|}{50} \\
\hline Tipo & Normal & \multicolumn{4}{|l|}{ Estruturas } \\
\hline Fabricante & NGK & Tipo & \multicolumn{3}{|c|}{$A$ e B } \\
\hline Referência & CA-525MR & Quantidade Total de Estruturas & \multicolumn{3}{|c|}{315} \\
\hline Quantidade & 25452 & Transposição de Fas & s (Compl & & \\
\hline
\end{tabular}




\begin{tabular}{|c|c|c|c|}
\hline \multicolumn{2}{|c|}{ Espaçadores } & Localização $(\mathrm{Km})$ & $42-85-130$ \\
\hline Tipo & Preformado & \multicolumn{2}{|c|}{ Parâmetros Elétricos } \\
\hline Fabricante & NGK & Impedância de sequência positiva & $\begin{array}{c}0.049+\mathrm{j} 0.432 \mathrm{pu} \\
\text { (Potencia base } 1000 \mathrm{MVA})\end{array}$ \\
\hline Referência & $2 \mathrm{H}-1486$ & Impedância de sequência Zero & $\begin{array}{c}0.3285+\mathrm{j} 1.3257 \mathrm{pu} \\
\text { (Potencia base 1000MVA) }\end{array}$ \\
\hline Quantidade & 4866 & Potência de curto-circuito trif - Furnas & 14027.3 MVA \\
\hline \multicolumn{2}{|c|}{ Amortecedores dos Condutores } & Potência de curto-circuito mon - Furnas & 13864.3 MVA \\
\hline Tipo & Stockbridge & Relação X/R monofásico & 15.8 \\
\hline Fabricante & Alcan & Relação X/R trifásico & 16.6 \\
\hline Referência & A-614k & & \\
\hline \multicolumn{2}{|c|}{ Amortecedores dos Para-raios } & Potência de curto-circuito trif - Poços & 12728.2 MVA \\
\hline Tipo & Stockbridge & Potência de curto-circuito mon - Poços & 9623.4 MVA \\
\hline Fabricante & Alcan & Relação X/R99993 monofásico & 9.5 \\
\hline Referência & A-603G & Relação X/R trifásico & 12.6 \\
\hline
\end{tabular}




\section{ANEXO B}

Procedimentos para Cálculo dos Fatores de Desempenho e Î́ndices de Mérito Agregado 
O anexo B define como foram feitos os cálculos, curvas e gráficos dos fatores de desempenho e dos índices de mérito agregado, utilizando as equações definidas no capitulo 3. A Tabela B-1 apresenta as grandezas coletadas nos barramentos da LT para a configuração 7, durante as simulações de fluxo carga em regime permanente. Esta configuração será utilizada como exemplo, para demonstração de como foram executados os cálculos, a construção das curvas e gráficos dos fatores de desempenho e índices de mérito agregado.

Conforme a Tabela B-1, observa-se que modelada a LT pela configuração 7, a carga acoplada no terminal receptor, foi aumentada gradativamente, mantendo um $\mathrm{FP}=0,95$, até que o sistema não mais convergiu, ou seja, não apresentou mais relação entre tensão e potência transmitida. Para cada valor de carga acoplada no receptor, efetuou-se o fluxo de carga, colhendo-se então as grandezas apresentadas nos barramentos, (P1,P2,V1,V2,I1,I2). Ressalta-se que o valor da carga acoplada deverá ser o valor de potência transmitida (P2). As grandezas foram colhidas em cada fase, e serão utilizadas a seguir: 
Tabela B-1 - Grandezas coletadas no fluxo de carga em regime permanente, pela configuração 7.

\begin{tabular}{|c|c|c|c|c|c|c|c|c|c|c|c|c|c|c|c|c|c|c|}
\hline & Carga no & Terminal & Receptor & & V1 (KV) & & & V2 (KV) & & & P1 (MW) & & & P2 (MW) & & & (kA) & \\
\hline & \begin{tabular}{|l|} 
MW \\
\end{tabular} & FP & MVA & A & & C & A & & C & A & & C & A & & C & A & & C \\
\hline P1 & 20,00 & 0,95 & \begin{tabular}{l|l|}
5 & 21,10 \\
\end{tabular} & 288,64 & 288,78 & 288,61 & 292,46 & 292,51 & 292,43 & 4,63 & 6,64 & 8,79 & 6,67 & 6,67 & 6,67 & 0,19 & 0,20 & 0,19 \\
\hline $\mathbf{P 2}$ & 50,00 & 0,95 & 52,74 & 288,64 & 288,78 & 288,61 & 291,81 & 291,93 & 291,92 & 14,63 & 16,65 & 18,79 & 16,66 & 16,67 & 16,67 & 0,18 & 0,19 & 0,19 \\
\hline P3 & 100,00 & 0,95 & 105,49 & 288,64 & 288,78 & 288,61 & 290,70 & 290,94 & 291,04 & 31,31 & 33,34 & 35,48 & 33,30 & 33,33 & 33,36 & 0,19 & 0,20 & 0,20 \\
\hline P4 & 150,00 & 0,95 & 158,23 & 288,64 & 288,78 & 288,61 & 289,56 & 289,93 & 290,13 & 48,01 & 50,04 & 52,18 & 49,93 & 50,00 & 50,07 & 0,21 & 0,22 & 0,22 \\
\hline P5 & 200,00 & 0,95 & 210,97 & 288,64 & 288,78 & 288,61 & 288,39 & 288,88 & 289,19 & 64,72 & 66,77 & 68,90 & 66,55 & 66,66 & 66,79 & 0,25 & 0,26 & 0,26 \\
\hline P6 & 250,00 & 0,95 & 263,71 & 288,64 & 288,78 & 288,61 & 287,20 & 287,81 & 288,23 & 81,46 & 83,52 & 85,64 & 83,15 & 83,33 & 83,53 & 0,29 & 0,30 & 0,31 \\
\hline P7 & 300,00 & 0,95 & 316,46 & 288,64 & 288,78 & 288,61 & 285,97 & 286,71 & 287,24 & 98,21 & 100,28 & 102,40 & 99,73 & 99,99 & 100,28 & 0,35 & 0,35 & 0,36 \\
\hline P8 & 350,00 & 0,95 & 369,20 & 288,64 & 288,78 & 288,61 & 284,71 & 285,58 & 286,22 & 114,98 & 117,07 & 119,18 & 116,30 & 116,65 & 117,06 & 0,40 & 0,41 & 0,41 \\
\hline P9 & 400,00 & 0,95 & 421,94 & 288,64 & 288,78 & 288,61 & 283,42 & 284,42 & 285,17 & 131,78 & 133,87 & 135,98 & 132,85 & 133,31 & 133,85 & 0,46 & 0,46 & 0,47 \\
\hline P10 & 450,00 & 0,95 & 474,68 & 288,64 & 288,78 & 288,61 & 282,09 & 283,22 & 284,09 & 148,59 & 150,70 & 152,80 & 149,38 & 149,96 & 150,66 & 0,52 & 0,52 & 0,53 \\
\hline P11 & 500,00 & 0,95 & 527,43 & 288,64 & 288,78 & 288,61 & 280,73 & 281,99 & 282,97 & 165,43 & 167,55 & 169,65 & 165,89 & 166,62 & 167,49 & 0,58 & 0,58 & 0,59 \\
\hline P12 & 550,00 & 0,95 & 580,17 & 288,64 & 288,78 & 288,61 & 279,34 & 280,73 & 281,82 & 182,28 & 184,42 & 186,51 & 182,39 & 183,27 & 184,34 & 0,64 & 0,64 & 0,65 \\
\hline P13 & 600,00 & 0,95 & 632,91 & 288,64 & 288,78 & 288,61 & 277,90 & 279,43 & 280,64 & 199,17 & 201,32 & 203,40 & 198,87 & 199,93 & 201,21 & 0,70 & 0,71 & 0,72 \\
\hline P14 & 650,00 & 0,95 & 685,65 & 288,64 & 288,78 & 288,61 & 276,43 & 278,08 & 279,41 & 216,07 & 218,24 & 220,32 & 215,33 & 216,58 & 218,10 & 0,76 & 0,77 & 0,78 \\
\hline P15 & 700,00 & 0,95 & 738,40 & 288,64 & 288,78 & 288,61 & 274,91 & 276,70 & 278,15 & 233,00 & 235,18 & 237,26 & 231,76 & 233,23 & 235,01 & 0,83 & 0,84 & 0,84 \\
\hline P16 & 750,00 & 0,95 & 791,14 & 288,64 & 288,78 & 288,61 & 273,35 & 275,28 & 276,85 & 249,96 & 252,16 & 254,23 & 248,18 & 249,87 & 251,94 & 0,90 & 0,90 & 0,91 \\
\hline P17 & 800,00 & 0,95 & 843,88 & 288,64 & 288,78 & 288,61 & 271,74 & 273,81 & 275,50 & 266,94 & 269,16 & 271,22 & 264,58 & 266,52 & 268,90 & 0,96 & 0,97 & 0,98 \\
\hline P18 & 850,00 & 0,95 & 896,62 & 288,64 & 288,78 & 288,61 & 270,08 & 272,30 & 274,11 & 283,95 & 286,19 & 288,24 & 280,95 & 283,17 & 285,89 & 1,03 & 1,04 & 1,05 \\
\hline P19 & 900,00 & 0,95 & 949,37 & 288,64 & 288,78 & 288,61 & 268,38 & 270,73 & 272,67 & 300,99 & 303,24 & 305,29 & 297,29 & 299,81 & 302,90 & 1,10 & 1,11 & 1,12 \\
\hline P20 & 950,00 & 0,95 & 1002,11 & 288,64 & 288,78 & 288,61 & 266,61 & 269,12 & 271,18 & 318,06 & 320,33 & 322,38 & 313,62 & 316,45 & 319,93 & 1,17 & 1,18 & 1,19 \\
\hline \begin{tabular}{|l|} 
P21 \\
\end{tabular} & 1000,00 & 0,95 & 1054,85 & 288,64 & 288,78 & 288,61 & 264,79 & 267,45 & 269,64 & 335,16 & 337,46 & 339,49 & 329,91 & 333,09 & 337,00 & 1,25 & 1,25 & 1,26 \\
\hline $\mathrm{P} 22$ & 1050,00 & 0,95 & 1107,59 & 288,64 & 288,78 & 288,61 & 262,91 & 265,71 & 268,04 & 352,30 & 354,62 & 356,65 & 346,18 & 349,73 & 354,09 & 1,32 & 1,32 & 1,33 \\
\hline P23 & 1100,00 & 0,95 & 1160,34 & 288,64 & 288,78 & 288,61 & 260,97 & 263,92 & 266,38 & 369,47 & 371,81 & 373,83 & 362,41 & 366,36 & 371,22 & 1,39 & 1,40 & 1,41 \\
\hline P24 & 1150,00 & 0,95 & 1213,08 & 288,64 & 288,78 & 288,61 & 258,95 & 262,06 & 264,65 & 386,68 & 389,05 & 391,06 & 378,62 & 383,00 & 388,38 & 1,47 & 1,47 & 1,48 \\
\hline P25 & 1300,00 & 0,95 & 1371,31 & 288,64 & 288,78 & 288,61 & 252,41 & 256,01 & 259,02 & 438,57 & 441,03 & 443,00 & 427,02 & 432,89 & 440,09 & 1,71 & 1,71 & 1,72 \\
\hline P26 & 1400,00 & 0,95 & 1476,79 & 288,64 & 288,78 & 288,61 & 247,57 & 251,52 & 254,83 & 473,41 & 475,94 & 477,88 & 459,08 & 466,14 & 474,78 & 1,88 & 1,88 & 1,89 \\
\hline P27 & 1500,00 & 0,95 & 1582,28 & 288,64 & 288,78 & 288,61 & 242,26 & 246,57 & 250,19 & 508,49 & 511,12 & 513,00 & 490,94 & 499,38 & 509,68 & 2,06 & 2,06 & 2,07 \\
\hline P28 & 1550,00 & 0,95 & 1635,02 & 288,64 & 288,78 & 288,60 & 239,38 & 243,88 & 247,68 & 526,15 & 528,82 & 530,68 & 506,77 & 515,99 & 527,23 & 2,15 & 2,16 & 2,17 \\
\hline P29 & 1600,00 & 0,95 & 1687,76 & 288,65 & 288,78 & 288,60 & 236,33 & 241,03 & 245,00 & 543,88 & 546,62 & 548,43 & 522,54 & 532,61 & 544,85 & 2,25 & 2,25 & 2,25 \\
\hline P30 & 1650,00 & 0,95 & 1740,51 & 288,65 & 288,78 & 288,60 & 233,09 & 237,99 & 242,14 & 561,72 & 564,51 & 566,29 & 538,23 & 549,22 & 562,56 & 2,35 & 2,36 & 2,37 \\
\hline P31 & 1700,00 & 0,95 & 1793,25 & 288,65 & 288,78 & 288,60 & 229,61 & 234,73 & 239,06 & 579,67 & 582,53 & 584,26 & 553,82 & 565,83 & 580,36 & 2,46 & 2,46 & 2,47 \\
\hline P32 & 1900,00 & 0,95 & 2004,22 & 288,66 & 288,77 & 288,59 & 212,07 & 218,22 & 223,41 & 653,18 & 656,47 & 657,82 & 614,74 & 632,23 & 653,02 & 2,97 & 2,98 & 2,99 \\
\hline
\end{tabular}




\section{B.1 DEMONSTRAÇÃO DE CÁlCULO DOS FATORES DE DESEMPENHO}

A tabela B-2 apresenta os resultados para os cálculos de rendimento e regulação para a configuração 7, os procedimentos para determinação dos resultados estão na sequência.

Tabela B-2 - Rendimento e regulação para configuração 7.

\begin{tabular}{|c|c|c|c|c|c|c|c|c|c|}
\hline \multicolumn{2}{|c|}{ Cargas } & \multicolumn{3}{|c|}{ Regulação por Fase \% } & \multicolumn{3}{|c|}{ Rendimento por Fase \% } & \multirow{2}{*}{ Regulação \% } & \multirow{2}{*}{ Rendimento \% } \\
\hline & MW & A & B & C & A & B & C & & \\
\hline P1 & 20,00 & $-1,31$ & $-1,28$ & $-1,31$ & 130,58 & 100,45 & 68,22 & $-1,30$ & 99,75 \\
\hline P2 & 50,00 & $-1,09$ & $-1,08$ & $-1,13$ & 112,18 & 100,12 & 87,28 & $-1,10$ & 99,86 \\
\hline P3 & 100,00 & $-0,71$ & $-0,74$ & $-0,83$ & 105,98 & 99,97 & 93,65 & $-0,76$ & 99,86 \\
\hline P4 & 150,00 & $-0,32$ & $-0,40$ & $-0,52$ & 103,85 & 99,92 & 95,79 & $-0,41$ & 99,85 \\
\hline P5 & 200,00 & 0,09 & $-0,03$ & $-0,20$ & 102,75 & 99,83 & 96,84 & $-0,05$ & 99,81 \\
\hline P6 & 250,00 & 0,50 & 0,34 & 0,13 & 102,03 & 99,77 & 97,47 & 0,32 & 99,76 \\
\hline P7 & 300,00 & 0,93 & 0,72 & 0,48 & 101,52 & 99,71 & 97,89 & 0,71 & 99,70 \\
\hline P8 & 350,00 & 1,38 & 1,12 & 0,84 & 101,13 & 99,64 & 98,19 & 1,11 & 99,65 \\
\hline P9 & 400,00 & 1,84 & 1,53 & 1,21 & 100,81 & 99,58 & 98,41 & 1,53 & 99,60 \\
\hline P10 & 450,00 & 2,32 & 1,96 & 1,59 & 100,53 & 99,51 & 98,58 & 1,96 & 99,54 \\
\hline P11 & 500,00 & 2,82 & 2,41 & 1,99 & 100,28 & 99,44 & 98,71 & 2,41 & 99,48 \\
\hline P12 & 550,00 & 3,33 & 2,87 & 2,41 & 100,06 & 99,37 & 98,82 & 2,87 & 99,42 \\
\hline P13 & 600,00 & 3,86 & 3,35 & 2,84 & 99,85 & 99,30 & 98,91 & 3,35 & 99,36 \\
\hline P14 & 650,00 & 4,42 & 3,85 & 3,29 & 99,66 & 99,23 & 98,98 & 3,85 & 99,29 \\
\hline P15 & 700,00 & 4,99 & 4,37 & 3,76 & 99,46 & 99,16 & 99,04 & 4,37 & 99,23 \\
\hline P16 & 750,00 & 5,59 & 4,90 & 4,25 & 99,28 & 99,08 & 99,09 & 4,92 & 99,16 \\
\hline P17 & 800,00 & 6,22 & 5,47 & 4,76 & 99,11 & 99,01 & 99,14 & 5,48 & 99,09 \\
\hline P18 & 850,00 & 6,87 & 6,05 & 5,29 & 98,93 & 98,93 & 99,18 & 6,07 & 99,02 \\
\hline P19 & 900,00 & 7,55 & 6,67 & 5,85 & 98,76 & 98,86 & 99,21 & 6,69 & 98,95 \\
\hline P20 & 950,00 & 8,26 & 7,31 & 6,43 & 98,58 & 98,77 & 99,23 & 7,33 & 98,88 \\
\hline P21 & 1000,00 & 9,01 & 7,98 & 7,04 & 98,41 & 98,69 & 99,26 & 8,01 & 98,80 \\
\hline $\mathbf{P 2 2}$ & 1050,00 & 9,79 & 8,68 & 7,67 & 98,23 & 98,60 & 99,28 & 8,71 & 98,72 \\
\hline P23 & 1100,00 & 10,60 & 9,42 & 8,35 & 98,05 & 98,51 & 99,30 & 9,46 & 98,64 \\
\hline P24 & 1150,00 & 11,47 & 10,20 & 9,05 & 97,87 & 98,42 & 99,31 & 10,24 & 98,56 \\
\hline P25 & 1300,00 & 14,35 & 12,80 & 11,42 & 97,30 & 98,12 & 99,34 & 12,86 & 98,29 \\
\hline P26 & 1400,00 & 16,59 & 14,81 & 13,26 & 96,88 & 97,90 & 99,35 & 14,89 & 98,09 \\
\hline $\mathbf{P 2 7}$ & 1500,00 & 19,14 & 17,12 & 15,36 & 96,43 & 97,65 & 99,35 & 17,21 & 97,87 \\
\hline P28 & 1550,00 & 20,58 & 18,41 & 16,52 & 96,18 & 97,51 & 99,35 & 18,50 & 97,75 \\
\hline P29 & 1600,00 & 22,14 & 19,81 & 17,80 & 95,92 & 97,37 & 99,34 & 19,92 & 97,62 \\
\hline P30 & 1650,00 & 23,84 & 21,34 & 19,19 & 95,64 & 97,22 & 99,34 & 21,45 & 97,49 \\
\hline P31 & 1700,00 & 25,71 & 23,03 & 20,72 & 95,33 & 97,05 & 99,33 & 23,15 & 97,34 \\
\hline
\end{tabular}

\section{B.1.1 Rendimento}

Para o cálculo do rendimento da configuração 7, utilizou-se a equação (3.1), definida anteriormente no capítulo 3. Observando a primeira simulação de potência transmitida, de 20 MW, na Tabela B-1, têm-se:

$$
\begin{aligned}
& P_{1}=\text { soma da potência de cada fase no transmissor } \\
& P_{2}=\text { soma da potência de cada fase no receptor }
\end{aligned}
$$




$$
\begin{aligned}
& P_{1}=4,63+6,64+8,79=20,06 \mathrm{MW} \\
& P_{2}=6,67+6,67+6,67=20,01 \quad \mathrm{MW}
\end{aligned}
$$

De acordo com a equação (3.1);

$$
\begin{gathered}
\eta=\left[1-\frac{\left(P_{1}-P_{2}\right)}{P_{2}}\right] \cdot 100 \\
\eta=\left[1-\frac{(20,06-20,01)}{20,01}\right] \cdot 100 \\
\eta=99,75 \%
\end{gathered}
$$

Assim para a potência transmitida de 20 MW tem-se um rendimento de $99,75 \%$. Este procedimento é feito para todas as cargas acopladas, contribuindo para a formação da Tabela B-2. Esta tabela apresenta todos os cálculos de rendimento para a configuração 7, incluindo ainda o rendimento de cada fase. Ressalta-se que esta tabela alimentará o gráfico apresentado pela Figura 4-8, que registra as curvas de rendimento para todas as configurações.

\section{B.1.2 Regulação}

O cálculo da Regulação foi semelhante ao rendimento, dessa vez utilizando as tensões apresentada na Tabela B-1, calculou-se através da equação (3.2), a regulação para cada fase, e posteriormente, a média aritmética da regulação nas três fases.

Considerando também a potência transmitida de $20 \mathrm{MW}$, temos:

$$
\begin{gathered}
R E G=\frac{V_{1}-V_{2}}{V_{2}} \cdot 100 \\
\text { REGfase } A=\frac{288,64-292,46}{292,46} \cdot 100=-1,31 \% \\
\text { REGfase B }=\frac{288,78-292,51}{292,51} \cdot 100=-1,28 \%
\end{gathered}
$$




$$
\text { REGfase } C=\frac{288,61-292,43}{292,43} \cdot 100=-1,31 \%
$$

Assim a regulação da LT para transmissão de 20 MW de potência é:

$$
\begin{gathered}
R E G=\frac{(-1,31)+(-1,28)+(-1,31)}{3} \\
R E G=-1,30 \%
\end{gathered}
$$

O resultado desse cálculo segue conforme a tabela B-2, juntamente com a regulação para todas as potências transmitidas pela configuração 7. Esta tabela alimentará a curva de regulação da configuração 7, que estará contida no gráfico apresentado como Figura 4-9.

\section{B.1.3 Capacidade de condução de corrente}

Para formação do gráfico apresentado na Figura 4-10, utilizou-se as curvas de todas as configurações propostas. Conforme a Tabela B-1, tratando-se da configuração 7, observase que para a formação da curva de capacidade de condução de corrente, utilizou-se a potência transmitida P2 e a corrente no transmissor I1. Ressalta-se que a corrente será igual entre I1 e I2.

Tomando como base novamente a transmissão de $20 \mathrm{MW}$, que é (P2), observa-se que a corrente relativa "I1" foi de 0,20 kA (sempre utilizar a fase de maior corrente, que nesse caso foi fase B).

\section{B.1.4 Limite de estabilidade de tensão (Curvas PV)}

O procedimento para formação do gráfico apresentado na Figura 4-11, pode ser entendido utilizando a tabela B-1, que registra para a configuração 7 todas as grandezas coletadas. Utiliza-se então a potência P2 no receptor, ou seja, somatório da potência em cada fase, pois o circuito é trifásico, e a tensão no receptor V2 (que é definida pela média aritmética das tensões em cada fase).

Assim para a primeira linha da Tabela B-1, que tem a carga em 20 MW: 


$$
\begin{aligned}
& P_{2}=6,67+6,67+6,67=20 \mathrm{MW} \quad(\text { é a propria carga acoplada) } \\
& V_{2}=\frac{292,46+292,51+292,43}{3}=292,47 \mathrm{kV}
\end{aligned}
$$

O procedimento é o mesmo para todas as cargas testadas em uma configuração, formando assim a relação de potência e tensão no receptor, alimentando as curvas PV, conforme a Figura 4-11.

\section{B.1.4 Perdas joule}

Para as perdas joule, utiliza-se também a tabela B-1 para a configuração 7. Para formar as curvas temos:

Perda joule $=(\mathrm{P} 1-\mathrm{P} 2)$

Sendo:

$\mathrm{P} 1$ = potência no transmissor

$\mathrm{P} 2$ = potência no receptor

A Figura 4-13 apresenta as perdas joule para todas as configurações propostas.

O eixo Y é representado pela "Perda joule" e o eixo X é representado pela potência transmitida no receptor, ou seja, o próprio P2.

A curva da configuração 7 é montada dessa forma para todas as potências transmitidas.

\section{B.1.5 Perdas por efeito corona, corona visual e rádio interferência}

Para o cálculo desses três fatores, é necessário, o cálculo do campo elétrico superficial do condutor " $E$ ", conforme as respectivas equações e procedimentos apresentados no capitulo 3 .

Assim a utilização do programa "CAMPO”, Campo (2005), é apresentada neste tópico para a determinação do campo elétrico superficial do condutor, conforme Domingues et al. (2005). 
Para cada configuração de repotenciação, a geometria da LT será alterada de acordo com suas características. A configuração 1 será utilizada para apresentar os procedimentos do programa CAMPO.

A Figura B-1 ilustra os parâmetros de cálculo do campo elétrico superficial do condutor, contendo o nível harmônico que se busca, a tolerância ao erro de cálculo do resultado do campo, e o nível de máximo harmônico que se busca. Ressalta-se que o nível 3 foi utilizado como padrão, conforme utilizado em Domingues et al. (2005).

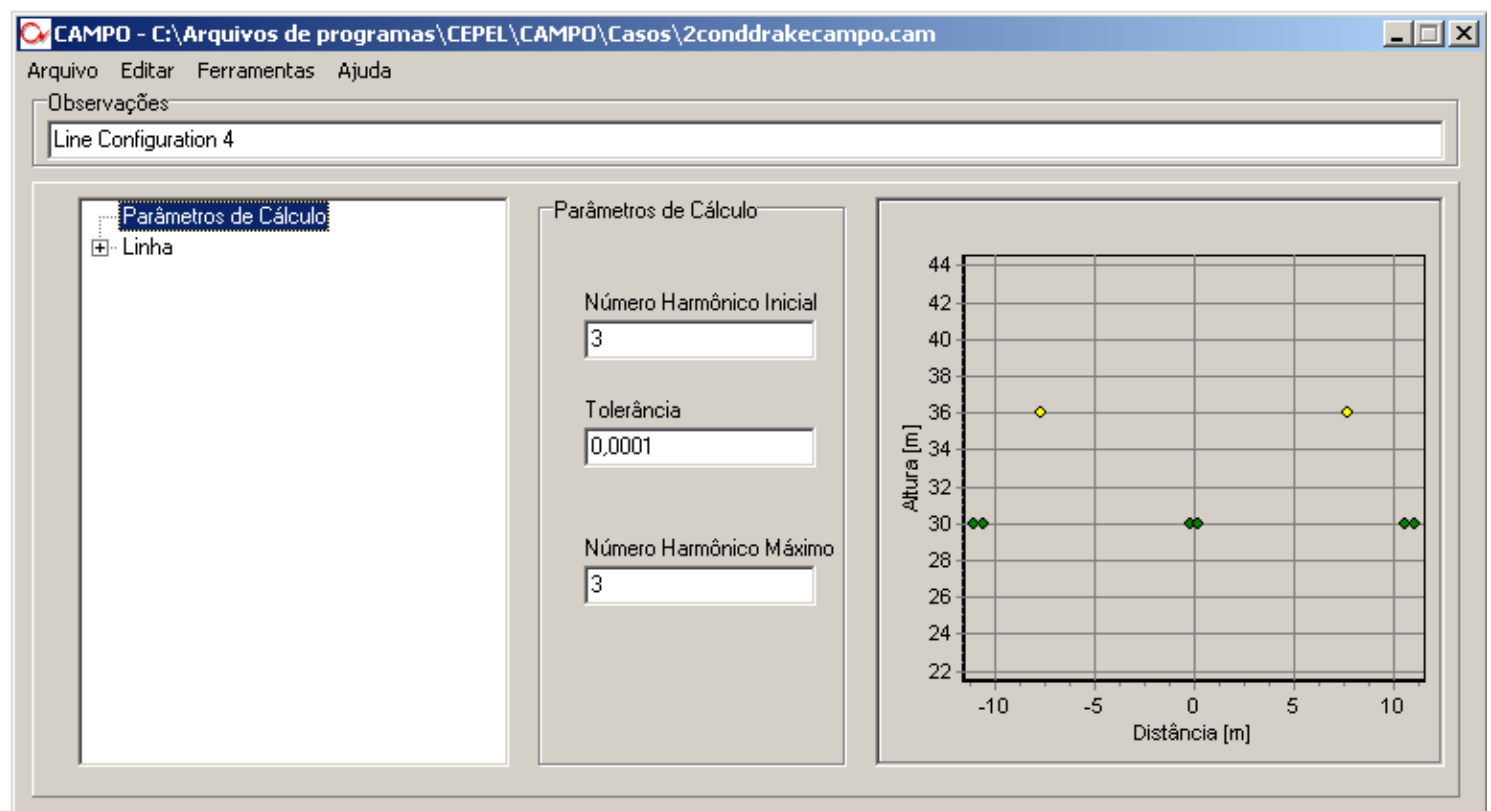

Figura B-1 - Parâmetros de cálculo do campo elétrico superficial do condutor

A Figura B-2 apresenta o número de condutores de cada fase, a tensão fase-neutro da LT, e a sequência angular que a fase encontra-se. Ressalta-se que foi adotada uma defasagem de 120 graus entre as fases. 


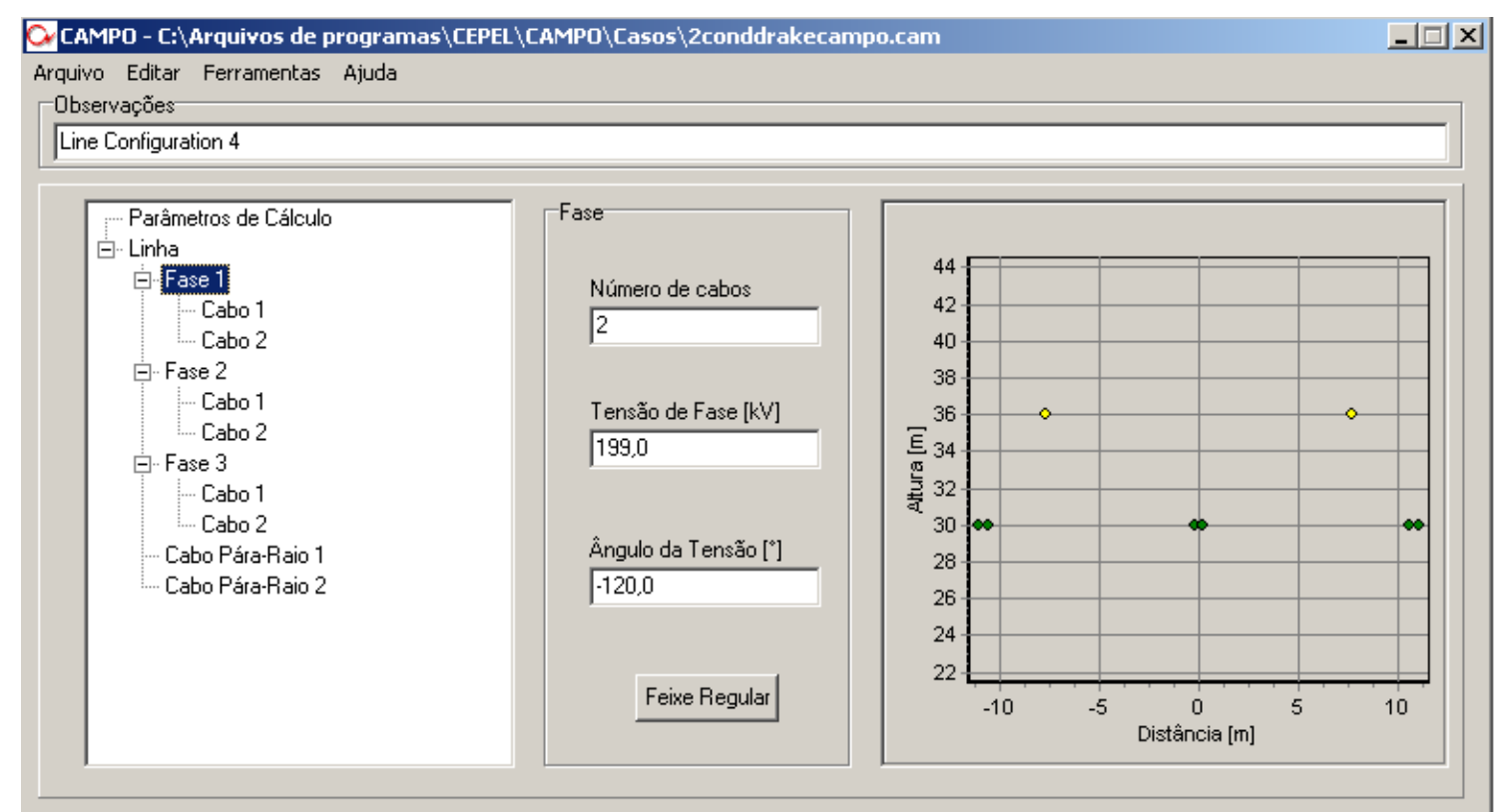

Figura B-2 - Dados da fase dos cabos da LT

A Figura B-3 ilustra a inserção dos dados geométricos do cabo condutor, como raio do condutor, distância do solo (coordenada vertical), e espaçamento do cabo em relação ao ponto zero, situado na fase central (coordenada horizontal). Nota-se que conforme os dados são inseridos, o programa apresenta um gráfico relacionando geometricamente os cabos condutores. Este procedimento é idêntico para a montagem dos cabos para-raios.

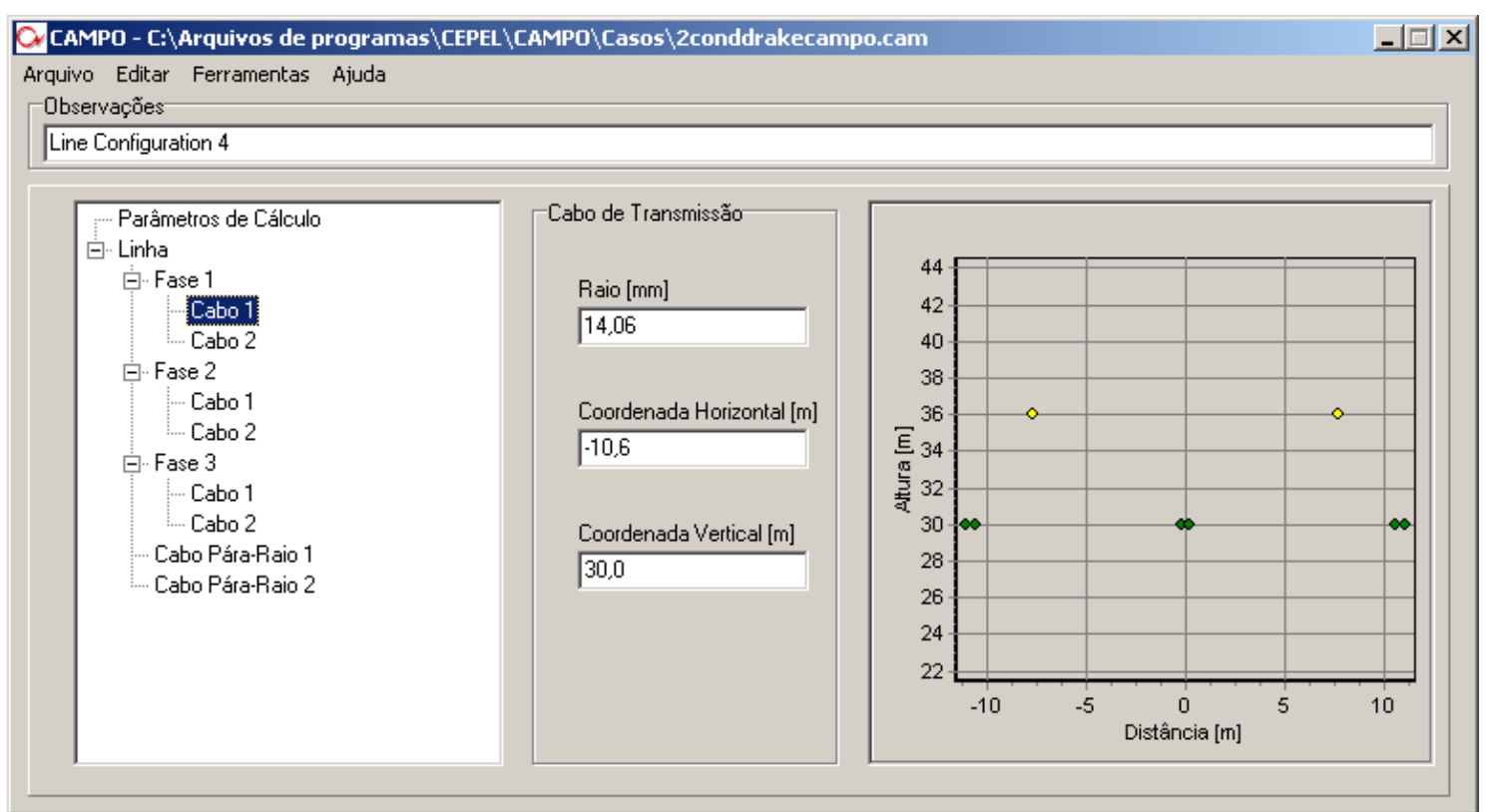

Figura B-3 - Dados geométricos dos cabos da LT 
Modelada a LT conforme ilustrado pelas figuras anteriores, ativa-se a execução dos resultados do programa, que resulta na Figura B-4, as informações do campo elétrico superficial de cada condutor, com seus valores mínimos e máximos. Ressalta-se que os valores desses campos utilizados nas equações dos fatores de desempenho, são os valores máximos.

A numeração desses condutores é indicada conforme a montagem das fases, que para configuração 1, apresenta 6 condutores fase e 2 condutores pára-raios.

Assim para a configuração 1, o valor do campo elétrico superficial do condutor utilizado foi de $14,85 \mathrm{kVef} / \mathrm{cm}$, apresentado pelo condutor 3 .

O valor de $E=14,85 \mathrm{kVef} / \mathrm{cm}$ para configuração 1, então é utilizado nas equações de perdas por efeito corona com e sem chuva, no cálculo do corona visual, e na equação da rádio-interferência. Para as demais configurações de repotenciação, o procedimento será o mesmo.

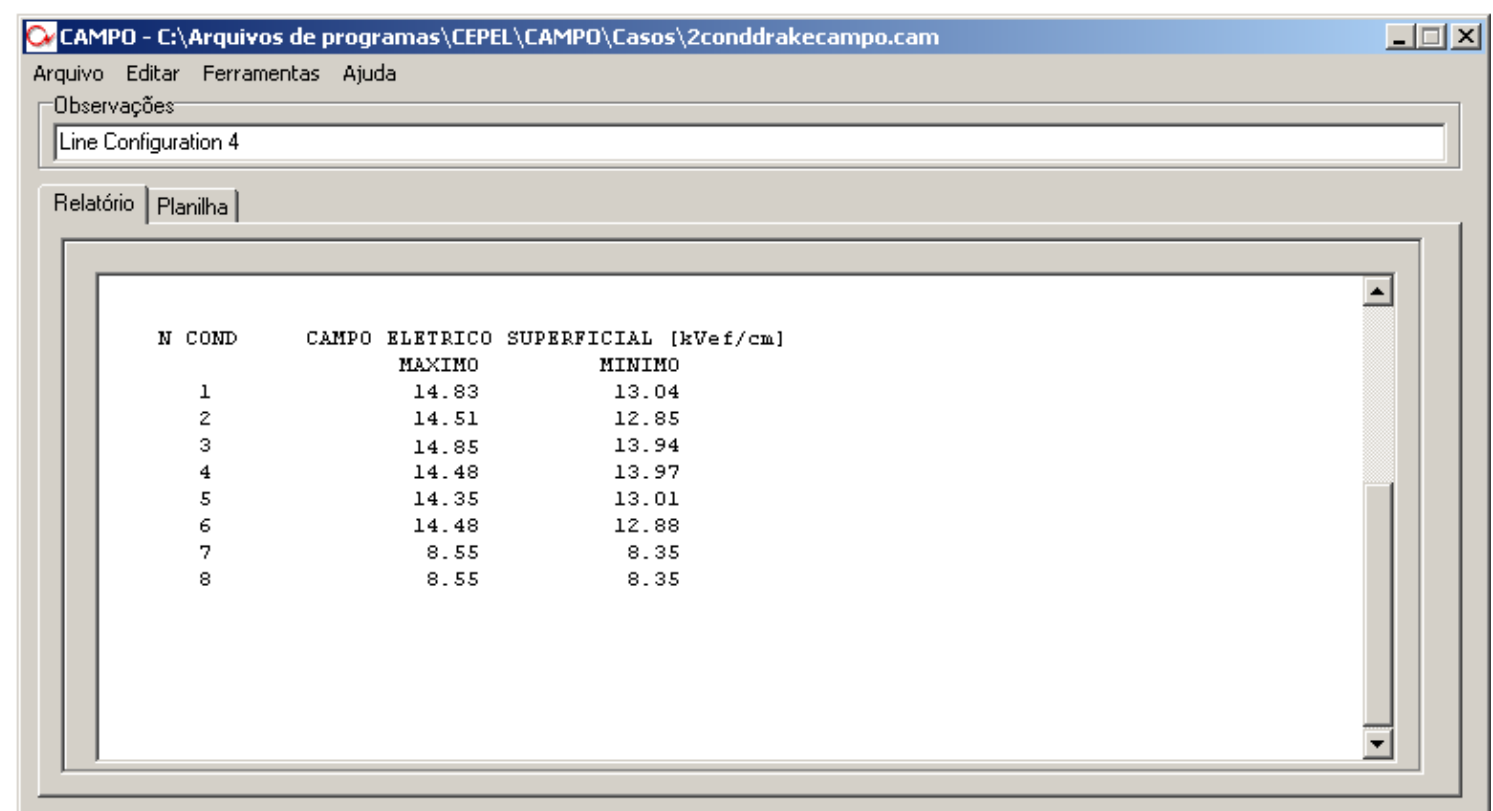

Figura B-4 - Resultado para Campo elétrico superficial dos condutores 


\section{B.1.6 Campo elétrico e Campo magnético}

Para o cálculo do campo elétrico, e campo magnético foi utilizado o programa CAMPEM, Campem (2004). As figuras seguintes apresentam a metodologia para cálculo destes fatores de desempenho.

A simulação computacional, refere-se a configuração 1 (dois condutores por fase, tipo Drake). A Figura B-5 mostra os dados do ponto de medição do campo elétrico e do campo magnético, sendo tipo esfera, com raio de $0,1 \mathrm{~m}$, e seus distanciamentos junto a LT.

Eixo $\mathrm{x}=$ distancia do objeto até a fase central da LT

Eixo y = altura do objeto em relação ao solo

Eixo $\mathrm{z}=$ comprimento ao longo do vão da LT

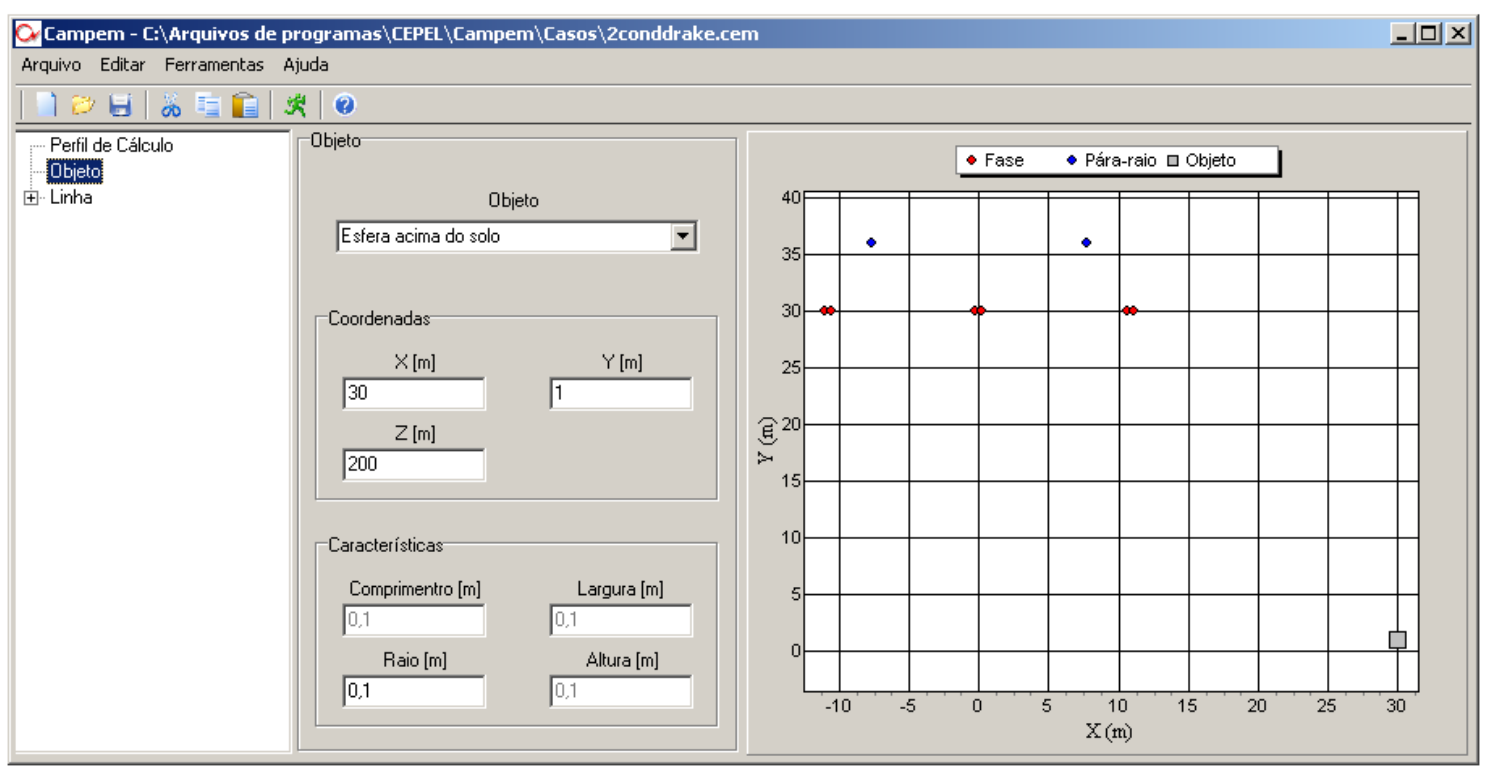

Figura B-5 - Dados do ponto de referência para medição

A Figura B-6 apresenta as características da LT, com número de fases, número de cabos pára-raios, frequência do sistema, comprimento do vão e resistividade do solo. Nota-se que conforme lançado essas informações, a configuração geométrica dos cabos é representada no gráfico da figura. Sendo os pontos vermelhos, os cabos condutores, e os pontos azuis, os cabos pára-raios, e por fim o ponto de medição como um quadrado cinza. 


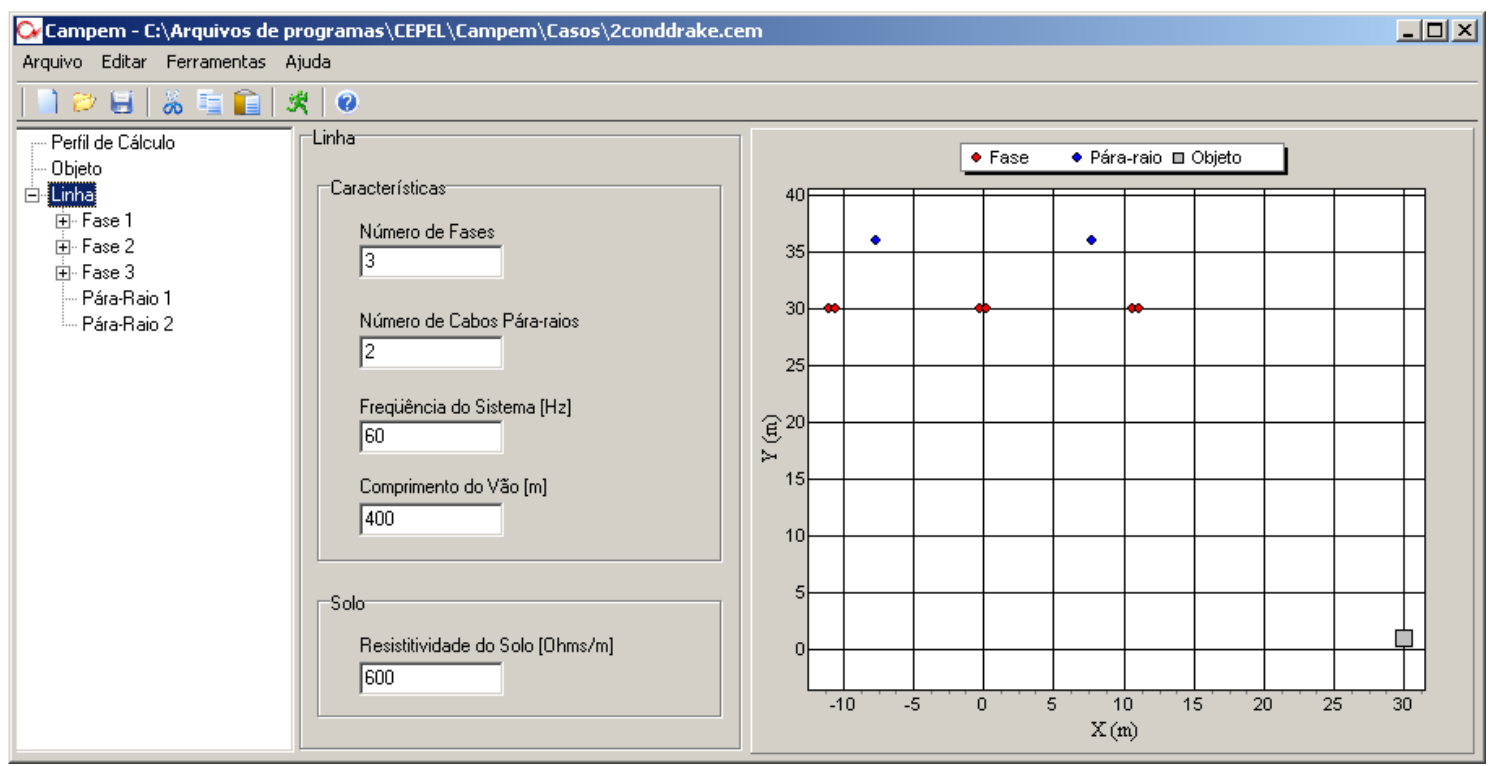

Figura B-6 - Dados característicos da LT

A Figura B-7 apresenta as características de cada fase da LT, contendo o número de cabos por fase, a flecha apresentada na fase, a tensão fase-neutro característica da LT, o defasamento angular da fase (sendo adotada a defasagem de 120 graus entre fases), e a corrente máxima da LT (1.218 A), adotada para todas as configurações propostas.

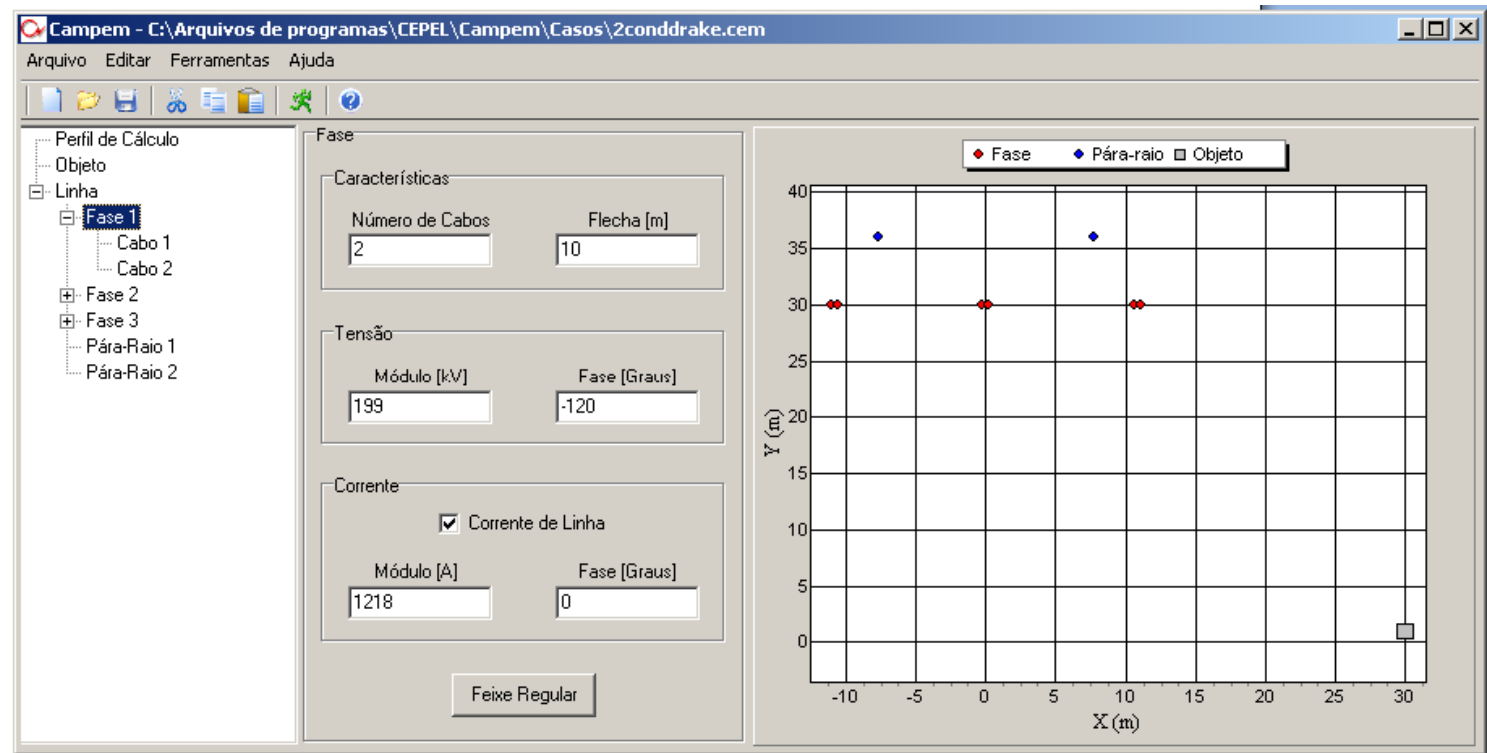

Figura B-7 - Dados característicos da fase da LT

A Figura B-8 apresenta o diâmetro do condutor, e as coordenadas em que os cabos se encontram perante o ponto zero do eixo X (fase central da LT). Já o eixo Y representa a altura em que o cabo condutor esta em relação ao solo. 
Este procedimento é efetuado para todas as fases e pára-raios, completando as informações necessárias para simulação do campo elétrico e campo magnético da LT.

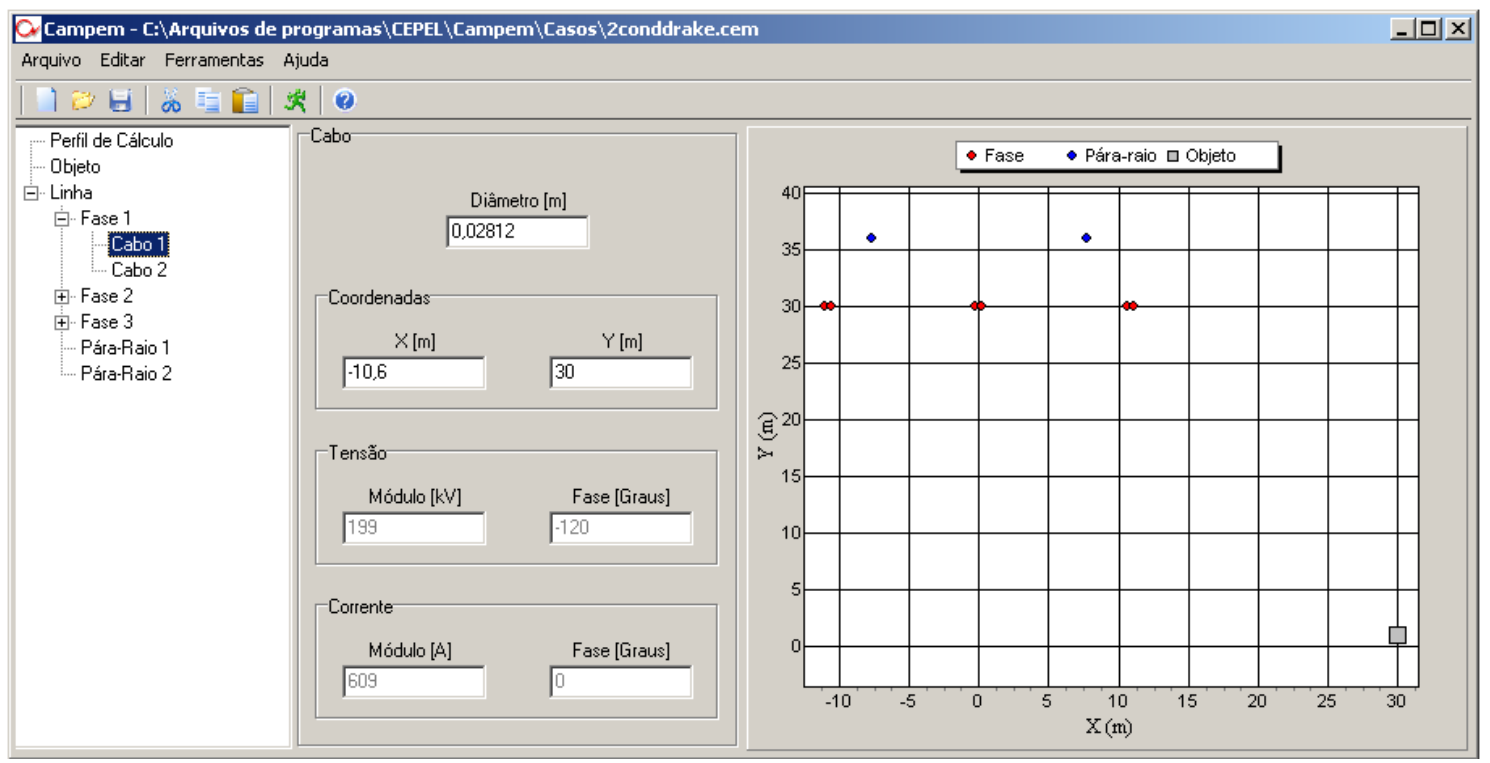

Figura B-8 - Dados geométricos dos cabos condutores de cada fase da LT

Com todos dados inseridos no programa, executa-se a simulação, que retornará os resultados através de planilhas e gráficos.

A Figura B-9, fornecida como resultado do campo elétrico para a configuração 1, apresenta os valores dos campos elétricos verticais e horizontais, e total.

Sendo:

$\mathrm{X}(\mathrm{m})=$ distância da fase central da LT (varia de -100 até +100$)$

$\mathrm{Y}(\mathrm{m})=$ altura do medidor em relação ao solo

$\mathrm{Z}(\mathrm{m})=$ comprimento medido entre os vãos da torre

$\mathrm{Ey}(\mathrm{kV} / \mathrm{m})=$ campo elétrico vertical

$\operatorname{Ex}(\mathrm{kV} / \mathrm{m})=$ campo elétrico horizontal

$\operatorname{Etotal}(\mathrm{kV} / \mathrm{m})=$ campo elétrico total

Ressalta-se que os valores do campo elétrico total, foram os resultados apresentados na Figura 4-14, no capítulo 4, contemplando assim os valores máximos encontrados. 


\begin{tabular}{|c|c|c|c|c|c|c|}
\hline \multicolumn{6}{|c|}{ 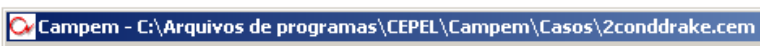 } & \multirow[t]{3}{*}{$-\mid \square x$} \\
\hline Arquivo Edita & tar $\mathrm{Fe}$ & rramentas Aij & & & & \\
\hline \multicolumn{6}{|c|}{$10 y=8$} & \\
\hline \multicolumn{7}{|c|}{ Campo Elétrico |Campo Magnético | } \\
\hline \multicolumn{2}{|c|}{ Gráfico } & $\sqrt{\text { 樽Tabela }}$ & \multicolumn{3}{|l|}{ 圆 Relatório } & \\
\hline$X(\mathrm{~m})$ & $Y(m)$ & $Z(m)$ & $E y(k V / m)$ & $\operatorname{Ex}(\mathrm{k} V / \mathrm{m})$ & Etotal $(\mathrm{k} V / \mathrm{m})$ & $\Delta$ \\
\hline$-100,00$ & 1,00 & 200,00 & 0,133 & 0,003 & 0,133 & - \\
\hline $.99,00$ & 1,00 & 200,00 & 0,136 & 0,003 & 0,136 & \\
\hline $.98,00$ & 1,00 & 200,00 & 0,138 & 0,003 & 0,138 & \\
\hline $.97,00$ & 1,00 & 200,00 & 0.141 & 0,003 & 0,141 & \\
\hline$-96,00$ & 1,00 & 200,00 & 0,144 & 0,003 & 0,144 & \\
\hline $.95,00$ & 1,00 & 200.00 & 0,147 & 0.003 & 0,147 & \\
\hline $.94,00$ & 1,00 & 200,00 & 0,149 & 0,003 & 0,150 & \\
\hline $.93,00$ & 1,00 & 200,00 & 0,152 & 0,003 & 0,153 & \\
\hline $.92,00$ & 1,00 & 200,00 & 0,156 & 0,003 & 0,156 & \\
\hline$-91,00$ & 1,00 & 200,00 & 0,159 & 0,003 & 0,159 & \\
\hline $.90,00$ & 1,00 & 200,00 & 0,162 & 0,003 & 0,162 & \\
\hline .89 .00 & 1.00 & 200,00 & 0.166 & 0.004 & 0,166 & -1 \\
\hline
\end{tabular}

Figura B-9 - Planilha de resultados campo elétrico

A Figura B-10 apresenta um gráfico com os valores apresentados na planilha da Figura B-9, porém, a Figura B-10 não foi utilizada na apresentação dos resultados do capítulo 4, sendo substituída pela Figura 4-14, que apresenta os mesmos valores, porém, no padrão das demais figuras gráficas da dissertação.

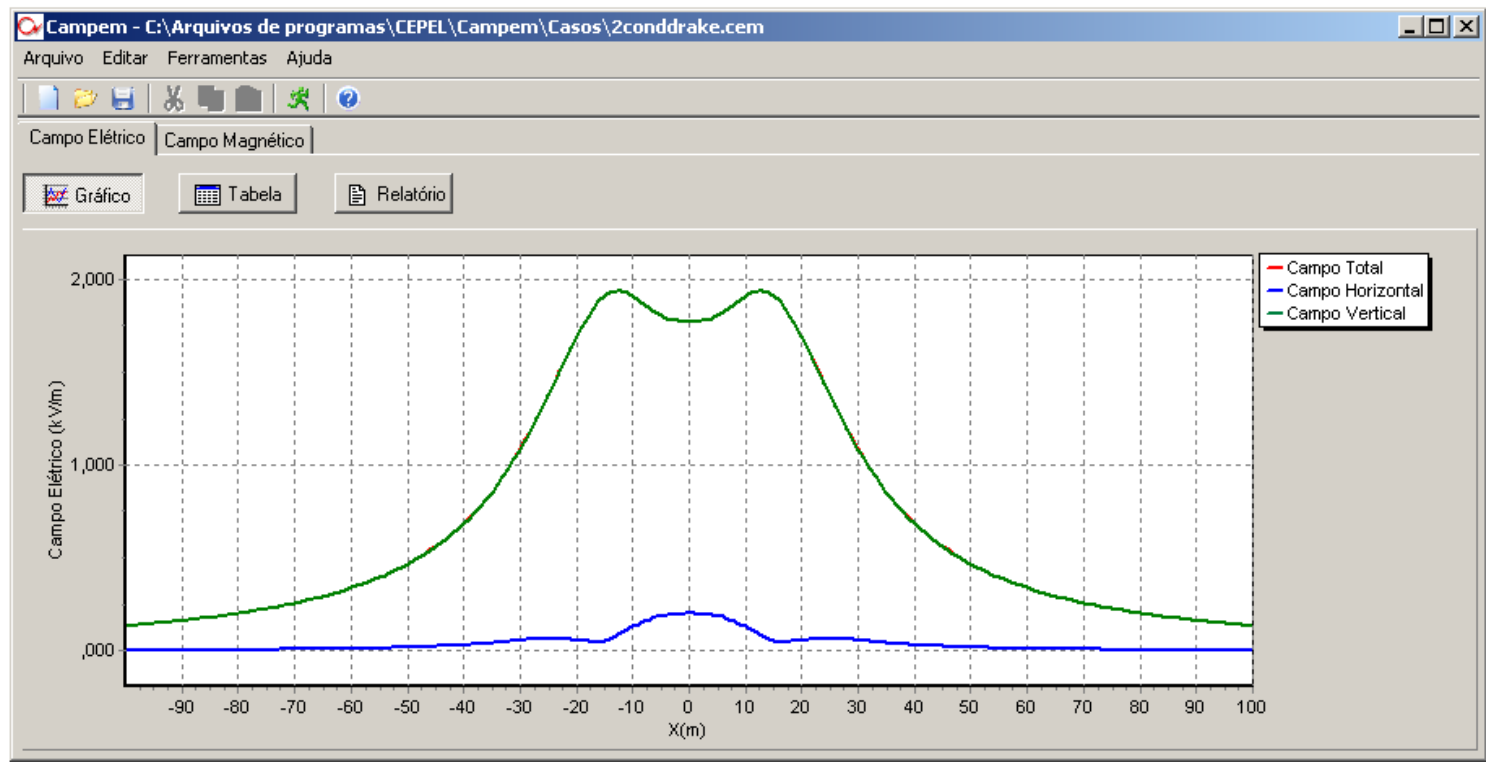

Figura B-10 - Gráfico resultante para campo elétrico

A Figura B-11 e a Figura B-12, correspondem a planilha e o gráfico resultantes para o campo magnético na configuração 1 . A 


\begin{tabular}{|c|c|c|c|c|c|c|}
\hline \multicolumn{6}{|c|}{ 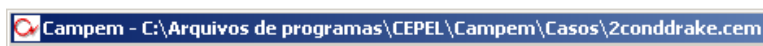 } & \multirow[t]{3}{*}{$-|\square| x$} \\
\hline \multicolumn{6}{|c|}{ Arquivo Editar Ferramentas Ajuda } & \\
\hline \multicolumn{6}{|c|}{ 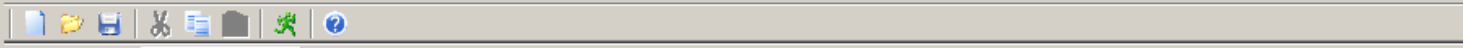 } & \\
\hline \multicolumn{7}{|c|}{ Campo Elétrico Campo Magnético | } \\
\hline \multicolumn{2}{|l|}{ Gráfico } & 典 Tabela & \multicolumn{3}{|c|}{ 睤 Relatório } & \\
\hline$x(m)$ & $Y(\mathrm{~m})$ & $Z(m)$ & $H y(m G)$ & $\mathrm{H} \times(\mathrm{mG})$ & Htotal (mG) & $\Delta$ \\
\hline$-100,00$ & 1,00 & 200,00 & 116,581 & 21,600 & 118,468 & \\
\hline $.99,00$ & 1,00 & 200,00 & 117,654 & 22,100 & 119,615 & \\
\hline $.98,00$ & 1.00 & 200,00 & 118,746 & 22,614 & 120,785 & \\
\hline$-97,00$ & 1.00 & 200,00 & 119,858 & 23,145 & 121,978 & \\
\hline$-96,00$ & 1,00 & 200,00 & 120,989 & 23,692 & 123,193 & \\
\hline$-95,00$ & 1,00 & 200,00 & 122,140 & 24,256 & 124,433 & \\
\hline$-94,00$ & 1,00 & 200,00 & 123,312 & 24,837 & 125,697 & \\
\hline$-93,00$ & 1,00 & 200,00 & 124,505 & 25,437 & 126,987 & \\
\hline $.92,00$ & 1.00 & 200,00 & 125,720 & 26,057 & 128,303 & \\
\hline $.91,00$ & 1,00 & 200,00 & 126,957 & 26,696 & 129,645 & \\
\hline$-90,00$ & 1,00 & 200,00 & 128,217 & 27,356 & 131,016 & \\
\hline$-89,00$ & 1,00 & 200,00 & 129,500 & 28,037 & 132,414 & $\nabla$ \\
\hline
\end{tabular}

Figura B-11 - Planilha resultante para campo magnético

De forma similar aos resultados do campo elétrico, a Figura 4-15 do capítulo 4, foi elaborada com os valores totais do campo magnético, apresentando os resultados para esse fator de desempenho.

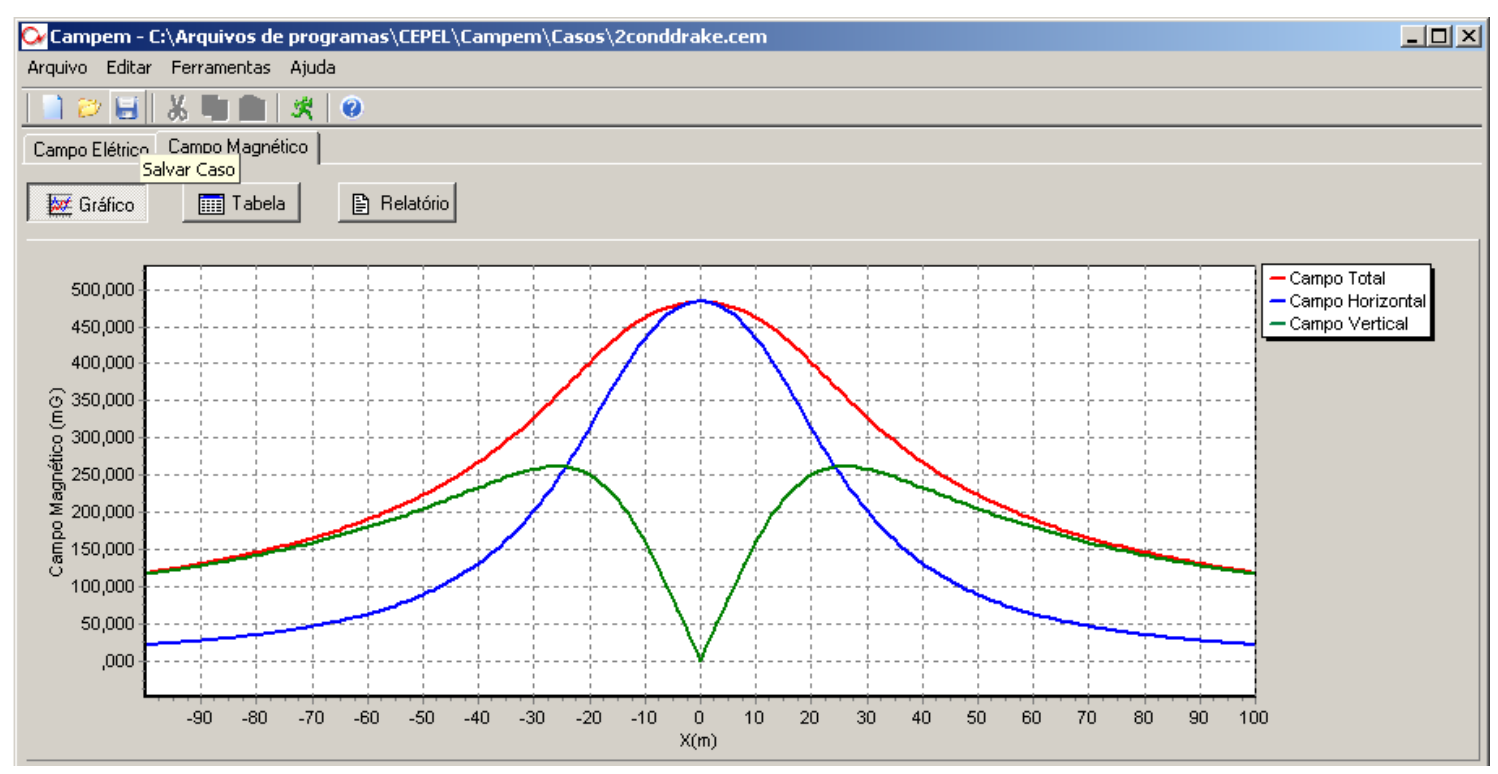

Figura B-12 - Gráfico resultante para campo magnético 


\section{B.2 DEMONSTRAÇÃO DE CÁLCULO DOS ÍNDICES DE MÉRITO AGREGADO}

\section{B.2.1 Índice de Máximo Carregamento (i MAXC $_{\text {) }}$}

Para cálculo desse índice utilizamos a equação (3.11), definida no capítulo 3. De acordo com a Tabela B-1, observa-se que a potência máxima transferida para a configuração 7 foi de $1900 \mathrm{MW}$, assim temos:

$$
\begin{aligned}
& P_{\text {MAX }}=1900 \mathrm{MW} \\
& P_{N}=\sqrt{3} \cdot V_{N} \cdot I_{N} \quad \text { (potência base utilizada em todos os índices) } \\
& P_{N}=\sqrt{3} \cdot 345 \cdot 1,218=727,83 \mathrm{MW} \\
& V_{N}=500 \mathrm{kV} \quad \text { (tensão nominal da configuração 7) } \\
& I_{N}=1,218 \mathrm{kA} \quad \text { (corrente nominal máxima da LT) }
\end{aligned}
$$

$$
\begin{gathered}
i_{M A X C}=\frac{P_{M A X}-P_{N}}{\sqrt{3} \cdot V_{N} \cdot I_{N}} \\
i_{M A X C}=\frac{1900-727,83}{\sqrt{3} \cdot 500 \cdot 1,218} \\
i_{M A X C}=1,11
\end{gathered}
$$

\section{B.2.2 Índice de Máximo Carregamento restrito por tensão (i $\mathbf{i}_{M A X C}$ )}

Para cálculo desse índice utiliza-se a Figura 4-11, que relaciona a tensão e potência no terminal receptor da LT. A $P_{M A X V}$ utilizada na equação (3.12), é a potência transmitida quando a tensão no receptor (V2) está em 0,95 pu. Assim temos:

$$
\begin{aligned}
& \mathrm{V} 2=0,95 \mathrm{pu} \\
& P_{M A X V}=720 \mathrm{MW} \\
& P_{N}=\sqrt{3} \cdot V_{N} \cdot I_{N} \text { (potência base utilizada em todos os índices) }
\end{aligned}
$$




$$
\begin{gathered}
P_{N}=\sqrt{3} \cdot 345 \cdot 1,218=727,83 \mathrm{MW} \\
V_{N}=500 \mathrm{kV} \quad(\text { tensão nominal da configuração } 7) \\
I_{N}=1,218 \mathrm{kA} \quad(\text { corrente nominal máxima da LT) } \\
i_{M A X C_{-} V}=\frac{P_{M A X V}-P_{N}}{\sqrt{3} \cdot V_{N} \cdot I_{N}} \\
i_{M A X C_{-} V}=\frac{720-727,83}{\sqrt{3} \cdot 500 \cdot 1,218} \\
i_{\text {MAXC_V }}=-0,01
\end{gathered}
$$

\section{B.2.3 Índice de Máximo Rendimento restrito por tensão (i $\left.\mathbf{i}_{M A X} \eta_{-} v\right)$}

Para o cálculo desses índices utiliza-se a equação (3.13). O valor de $P_{\text {MAXV }}$ é definido conforme anteriormente. De posse do valor de $P_{M A X V}$, utiliza-se a Figura 4-8 para determinar $\eta_{M A X_{-} V}$. A figura relaciona o rendimento para a potência transmitida. Assim temos para a configuração 7, dada como referência.

$$
\begin{array}{r}
P_{M A X V}=720 \mathrm{MW} \\
\eta_{M A X_{-} V}=99,2 \% \\
\left.V_{N}=500 \mathrm{kV} \quad \text { (tensão nominal da configuração } 7\right) \\
I_{N}=1,218 \mathrm{kA} \quad \text { (corrente nominal máxima da LT) } \\
i_{M A X \eta_{-} V}=\frac{\eta_{M A X_{-} V}}{100} \cdot \frac{P_{M A X V}}{\sqrt{3} \cdot V_{N} \cdot I_{N}} \\
i_{M A X \eta_{-} V}=\frac{99,2}{100} \cdot \frac{720}{\sqrt{3} \cdot 500 \cdot 1,218} \\
i_{M A X \eta_{-} V}=0,98
\end{array}
$$




\section{B.2.4 Índice de Máxima Regulação restrito por tensão (i $\left.\mathbf{i}_{M A X R_{-} V}\right)$}

Utilizando a equação (3.14) calcula-se este índice, que relaciona a máxima tensão da LT (restrita pela tensão de 0,95 pu no terminal receptor, conforme Figura 4-8), com a regulação da LT apresentada pela Figura 4-9. Assim temos para a configuração 7:

$$
\begin{aligned}
& P_{M A X V}=720 \mathrm{MW} \\
& R_{M A X_{-} V}=4,5 \% \\
& V_{N}=500 \mathrm{kV} \quad \text { (tensão nominal da configuração 7) } \\
& I_{N}=1,218 \mathrm{kA} \quad \text { (corrente nominal máxima da LT) }
\end{aligned}
$$

$$
\begin{gathered}
i_{\text {MAXR } ~_{-}}=\frac{100}{R_{M A X_{-} V}} \cdot \frac{P_{M A X V}}{\sqrt{3} \cdot V_{N} \cdot I_{N}} \\
i_{M A X R_{-} V}=\frac{100}{4,5} \cdot \frac{720}{\sqrt{3} \cdot 500 \cdot 1,218} \\
i_{\text {MAXR_V }_{-}}=15,17
\end{gathered}
$$


ANEXO C

\section{Requisitos Mínimos para Linhas de Transmissão}


As linhas de transmissão operam sob tensão elevada, então o dimensionamento de suas estruturas, a escolha do espaçamento entre estas (vãos), a resistência mecânica dos condutores e isoladores, bem como cuidados em sua construção devem ser objetos de toda consideração, a fim de que ofereçam absoluta segurança, não colocando em risco vidas e propriedades.

O objetivo deste tópico é estabelecer os requisitos técnicos mínimos utilizados neste trabalho de repotenciação da LT estudada, conforme ONS (2000), e também pela NBR-5422 (1985). Através desta norma regulamentadora e dos requisitos mínimos para LT do ONS, são fixadas condições básicas a serem atendidas na transmissão da energia elétrica por vias aéreas, como condições gerais, elétricas e mecânicas. Dentre estas, destacam-se os dados de cabos condutores e para-raios, distâncias de segurança, isoladores, parâmetros meteorológicos, perdas, limites de carregamento, emissões eletromagnéticas, isolamento a manobras, desempenho a descargas atmosféricas, cargas mecânicas sobre as estruturas, dentre outros. Nos itens seguintes, segue a descrição dos requisitos mínimos para linhas de transmissão aéreas adotados neste trabalho.

\section{C.1 CÁlCULO DO ISOLAMENTO À TENSÃO MÁXIMA OPERATIVA}

O isolamento da linha de transmissão à tensão máxima operativa deve manter-se íntegro, estando a cadeia de isoladores em balanço sob ação do vento com período de retorno de, no mínimo, 30 anos.

Devem ser mantidas as distâncias mínimas de segurança, de modo a evitar descarga à tensão máxima operativa entre qualquer condutor da linha e elementos da estrutura da torre ou objetos situados no limite da faixa de servidão, nas condições especificadas conforme NBR-5422 (1985). 


\section{C.2 CÁLCULO DAS DISTÂNCIAS DE SEGURANÇA}

Os critérios para cálculos das distâncias de segurança utilizados neste trabalho foram baseados no "Critério das distâncias disruptivas da cadeia de isoladores" segundo Fuchs (1982). Este critério abrange o cálculo de distâncias mínimas de segurança recomendáveis no projeto de linhas de transmissão, respeitando as distâncias de segurança adotadas por Furnas e pela NBR-5422. Ainda neste anexo serão apresentados os cálculos que proporcionaram a determinação das distâncias seguintes apresentadas.

a) Distâncias mínimas no suporte: conforme orientação da NBR-5422 as distâncias mínimas no suporte devem ser obrigatoriamente determinadas levando em consideração as várias solicitações elétricas em que a linha de transmissão será submetida, devidamente coordenadas com as condições de vento. O correto cálculo da geometria dos suportes e/ou isoladores é de extrema importância para garantir as recomendações de segurança.

b) Distâncias horizontais: as distâncias mínimas horizontais ou espaçamento entre os condutores fase devem manter-se em um limite que não cause curto-circuito entre os condutores dispostos horizontalmente; os distanciamentos devem ser mantidos íntegros mesmo com ação do vento e balanço da cadeia de isoladores.

c) Distâncias verticais: distâncias medidas verticalmente entre o solo e os condutores, considerando a parte baixa da flecha máxima dos mesmos. Esta distância determina a quantidade de material que a torre necessita, se será necessário aumento de altura na estrutura das torres, redimensionamento de isoladores, ou retensionamento de cabos condutores.

A Tabela C-1Erro! Fonte de referência não encontrada. informa as distâncias verticais limites recomendadas pela NBR-5422, de acordo com o traçado da LT e respectiva tensão operativa. As distâncias limites consideram a parte mais baixa apresentada pelos 
condutores da LT e o ponto mais alto das referências citadas. As distâncias limites apresentadas, são calculadas para a temperatura máxima nominal do condutor (condição que o condutor apresenta a maior flecha) e em condições atmosféricas sem vento.

Tabela C-1- Tabela de valores dos espaçamentos verticais em diferentes condições, de acordo com os níveis de tensão de transmissão (Norma NBR-5422).

\begin{tabular}{|c|c|c|c|c|c|}
\hline \multirow{2}{*}{ Referências } & \multicolumn{5}{|c|}{ Valores mínimos em (metros) } \\
\cline { 2 - 6 } & $\mathbf{1 3 8 k \mathbf { V }}$ & $\mathbf{2 3 0 k \mathbf { V }}$ & $\mathbf{3 4 5 \mathbf { k V }}$ & $\mathbf{5 0 0 k V}$ & $\mathbf{7 5 0 k \mathbf { k }}$ \\
\hline Locais acessíveis somente a pedestres. & 7,0 & 7,5 & 8,0 & 9,5 & 13,0 \\
\hline $\begin{array}{c}\text { Locais acessíveis a máquinas } \\
\text { agrícolas. }\end{array}$ & 7,5 & 8,0 & 9,0 & 10,0 & 15,0 \\
\hline $\begin{array}{c}\text { Rodovias federais e rodovias } \\
\text { estaduais de primeira classe (tráfego } \\
\text { intenso). }\end{array}$ & 8,7 & 9,7 & 10,8 & 12,4 & 30,0 \\
\hline $\begin{array}{c}\text { Demais rodovias estaduais e rodovias } \\
\text { municipais muito utilizadas. }\end{array}$ & 8,7 & 9,7 & 10,8 & 12,4 & 20,0 \\
\hline $\begin{array}{c}\text { Demais rodovias municipais, ruas, } \\
\text { avenidas, estradas de fazendas e } \\
\text { carroçáveis. }\end{array}$ & 8,2 & 9,2 & 10,3 & 11,9 & 16,0 \\
\hline $\begin{array}{c}\text { Ferrovias não eletrificadas. } \\
\text { Ferrovias eletrificadas ou com } \\
\text { previsão de eletrificação. }\end{array}$ & 9,7 & 10,7 & 11,8 & 13,4 & 16,0 \\
\hline $\begin{array}{c}\text { Linhas de distribuição, } \\
\text { telecomunicação e transmissão. }\end{array}$ & 3,0 & 4,0 & 5,0 & 7,0 & 8,7 \\
\hline $\begin{array}{c}\text { Estruturas pertencentes a ferrovias } \\
\text { eletrificadas. }\end{array}$ & 4,7 & 5,7 & 6,8 & 8,4 & 11,0 \\
\hline Edificações. & 4,7 & 5,7 & 6,8 & 8,4 & 13,0 \\
\hline $\begin{array}{c}\text { Águas navegáveis (ponto mais alto } \\
\text { da embarcação). }\end{array}$ & 2,7 & 3,7 & 4,8 & 6,4 & 9,0 \\
\hline $\begin{array}{c}\text { Águas não navegáveis. } \\
\text { Futuras linhas de distribuição ou } \\
\text { comunicação (sem indicação de altura } \\
\text { no perfil). }\end{array}$ & 14,0 & 15,0 & 16,0 & 18,0 & 19,7 \\
\hline
\end{tabular}

d) Distância dos cabos para-raios: tradicionalmente os cabos para-raios são montados em posição que assegurem a proteção dos condutores contra descargas diretas. Isso é conseguido na medida em que o ângulo entre o plano vertical que passa pelo centro dos cabos para-raios, e outro ligando o seu centro aos condutores sejam da ordem de 25 a $35^{\circ}$. As linhas assim construídas desempenham satisfatoriamente nas presentes classes de tensão. 


\section{C.2.1. Cálculos das distâncias disruptivas da cadeia de isoladores}

Os isoladores são equipamentos fundamentais para o bom desempenho da LT, e com relação aos condutores possuem a função de sustentá-los ou ancorá-los através das estruturas. Os isoladores também estão sujeitos a solicitações mecânicas e elétricas.

- Solicitações mecânicas:

- Forças verticais pelo peso dos condutores;

- Forças horizontais axiais para suspensão;

- Forças horizontais transversais pela ação dos ventos.

- Solicitações Elétricas:

- Tensão nominal e sobretensão em frequência industrial;

- Oscilações de tensão de manobra;

- Descargas atmosféricas.

Os isoladores devem oferecer uma alta resistência para correntes de fuga de superfície e serem suficientemente espesso para prevenir ruptura sob as condições de tensão que devem suportar.

Como já salientado, os critérios para cálculo da isolação à máxima tensão operativa da LT, foram baseados no "Critério das distâncias disruptivas da cadeia de isoladores" e nas técnicas já estabelecidas por Furnas. Para a repotenciação da LT serão utilizados os mesmos tipos de isoladores, com mesmas dimensões e meios de montagem, objetivando um correto e econômico redimensionamento dos seus componentes.

O número de isoladores de uma cadeia é fixado pelo critério das tensões em frequência industrial, dado pela expressão (C.1).

$$
N i=\frac{U_{M} / \sqrt{3}}{d_{D} / d_{e}}
$$

Sendo: 
$\mathrm{Ni}=$ número de isoladores

$U_{M}=$ tensão máxima de exercício para a classe de tensão da linha $[\mathrm{kV}]$;

$d_{D}=$ distância de escoamento específica dos isoladores (dos catálogos dos fabricantes) [cm];

$d_{e}=$ distância de escoamento específica $[\mathrm{cm} / \mathrm{kV}]$, (depende do índice de poluição do ar na região atravessada pela linha);

As distâncias assim determinadas são em geral maiores do que as distâncias mínimas exigidas pelas normas técnicas. Por seguinte, o comprimento básico para o dimensionamento elétrico das cadeias de isoladores, é chamada de "distância de descarga", definida como:

$$
D_{D}=d_{D}+p(n-1)
$$

$D_{D}=$ distância de descarga $[\mathrm{m}]$;

$d_{d}=$ distância de escoamento de uma unidade de isolador (dos catálogos de fabricantes de isoladores) $[\mathrm{m}]$;

$p=$ passo do isolador $[\mathrm{m}]$;

$n=$ número de isoladores.

De acordo com esses critérios, a distância mínima entre as partes energizadas e as partes aterradas das estruturas deverá ser no mínimo igual ao valor da distância disruptiva ou distância de descarga da cadeia. Nas cadeias de suspensão, que é o caso da LT estudada, essa distância deverá ser observada sob todas as condições de funcionamento, especialmente quando a cadeia de isoladores se encontra deslocada sob a ação da força do vento; a Figura C- 1 representa a situação. 


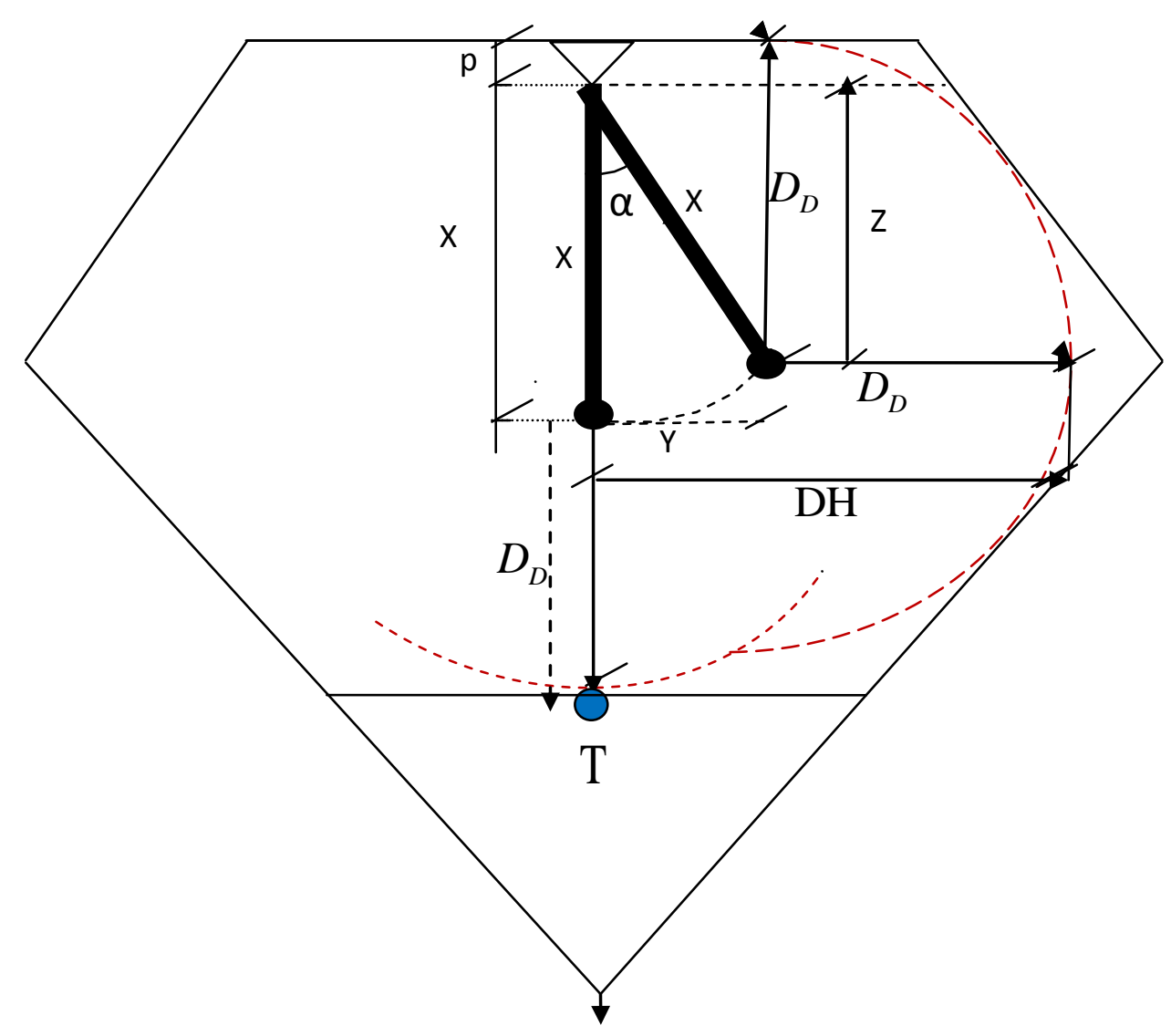

Figura C- 1- Dimensões mínimas da janela de estrutura com cadeia em I

Em que:

$\mathrm{X}=$ comprimento da cadeia de isoladores

$\mathrm{Y}=$ distância horizontal da posição normal do isolador até a posição máxima de abertura

$D_{D}=$ distância de descarga

$\alpha=$ ângulo máximo de abertura da cadeia de isoladores

$\mathrm{p}=$ comprimento do suporte do isolador

$\mathrm{T}=$ ponto que representa a parte da estrutura da torre

A Figura C- 1 representa a ancoragem da fase central da LT por uma cadeia de isoladores, submetida a uma tensão máxima de operação, e com a movimentação da cadeia devido à ação do vento. 
A distância mínima do suporte será a própria $D_{D}$, calculada conforme mostrado anteriormente, considerando esta distância a partir da extremidade do isolador com o máximo ângulo de abertura até a parte superior da estrutura, ao mesmo nível do suporte do isolador. Na fase central, também é considerada a $D_{D}$, como a distância mínima de segurança entre a fase e a parte da estrutura da torre logo abaixo, representada pelo ponto $\mathrm{T}$.

A distância mínima horizontal (ou entre fases) é o espaçamento representado por DH, submetido ao máximo ângulo de abertura $\alpha$ da cadeia de isoladores.

A distância vertical será calculada de acordo com a variação do comprimento da cadeia de isoladores, que conforme o aumento da tensão da LT, maior o comprimento da cadeia, e por seguinte diminui-se a distância vertical entre condutores e solo.

Apresenta-se a seguir o cálculo de isoladores e distâncias mínimas de segurança para a LT em $345 \mathrm{kV}$, sendo que os dados dos isoladores foram retirados dos catálogos dos fabricantes.

$U_{M}=379(10 \%$ superior a tensão nominal da LT)

$d_{D}=30,5$

$d_{e}=2,3$

$$
N i=\frac{379 / \sqrt{3}}{30,5 / 2,3}=16,5 \cong 17
$$

A LT possui originalmente 20 isoladores em sua cadeia, então não será necessário fazer alterações na cadeia de isoladores, pois ela está dimensionada corretamente, possuindo três isoladores adicionais ao limite, atendendo então a máxima tensão operativa da LT, para tensão nominal em $345 \mathrm{kV}$. Assim todas as distâncias de segurança são atendidas, para todas 
as técnicas de repotenciação em $345 \mathrm{kV}$ aplicadas neste projeto, mantendo a isolamento à tensão máxima operativa.

Os cálculos dos isoladores e das distâncias mínimas de segurança para as técnicas de repotenciação em 500 kV são apresentados em seguida:

$U_{M}=550(10 \%$ superior à tensão nominal da LT)

$d_{D}=30,5$

$d_{e}=2,3$

$$
N i=\frac{550 / \sqrt{3}}{30,5 / 2,3}=23,94 \cong 24
$$

Para atender às distâncias de segurança e manter o isolamento à tensão máxima operativa, será necessária a adição de quatro isoladores na cadeia, que originalmente possuía vinte isoladores.

No cálculo da distância de descarga, utilizam-se também as características dos isoladores em operação na LTFUPC1, e através da equação (C.2) tem-se que:

$d_{d}=0,30$

$p=0,16$

$n=20$

$$
D_{D}=0,30+0,16(24-1)=3,98
$$

O comprimento da cadeia de isoladores em $345 \mathrm{kV}$, é de $3,5 \mathrm{~m}$ com 20 isoladores, então cada isolador contém uma média de 0,175 m de comprimento.

Com a adição de mais quatro isoladores na cadeia, o comprimento da cadeia de isoladores para $500 \mathrm{kV}$ será de:

$$
3,5+(4 \times 0,175)=4,2 \mathrm{~m}
$$


Assim, a distância vertical entre condutores e solo diminuirá de 30 m para 29,3 m. Considerando a flecha de $10 \mathrm{~m}$ para carregamento máximo da LT, então a distância real entre condutores fase e solo será de 19,3 m, condição aceitável para as normas regulamentadoras.

O traçado da LT é variável, podendo haver em locais com maiores desníveis, a necessidade de aumento da altura das estruturas, porém o fato foi levantado com técnicos de Furnas, e concluiu-se que são menos de 10 pontos necessários para tais modificações, acarretando baixo custo para as alterações.

As demais distâncias de segurança para a repotenciação em 500 kV foram calculadas como segue na Figura C- 2:

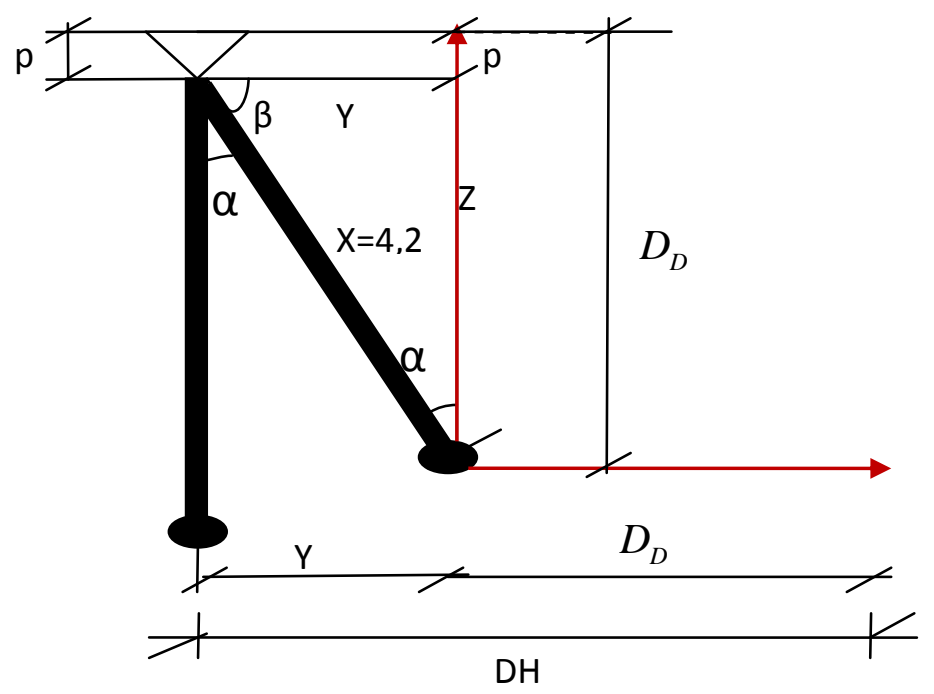

Figura C- 2- Cálculo das distâncias disruptivas.

$$
\begin{gathered}
X^{2}=Y^{2}+Z^{2} \\
Y^{2}=X^{2}-Z^{2} \\
Y^{2}=4,2^{2}-(3,98-0,7)^{2} \\
Y=\sqrt{6,88}=2,62 \\
\mathrm{DH}=\mathrm{Y}+\mathrm{D}_{D}
\end{gathered}
$$




$$
\begin{gathered}
\mathrm{DH}=2,62+3,98 \\
\mathrm{DH}=6,6
\end{gathered}
$$

A distância horizontal $\mathrm{DH}=$ 6,6 metros é a distância de segurança horizontal mínima entre fases. A distância entre fases da LT é de 10,6 m, não necessitando alterações nestes distanciamentos.

O valor da distância de descarga $D_{D}=3,98 \mathrm{~m}$ é a própria distância para a estrutura das torres para tensão em $500 \mathrm{kV}$.

O ângulo máximo de abertura dos isoladores devido ao balanço provocado pelos ventos é determinado como segue:

$\mathrm{De}=5,8$

$\mathrm{Y}=5,8-3,98$

$$
\begin{gathered}
\operatorname{sen} \alpha=\frac{Y}{X} \\
\alpha=\operatorname{sen}^{-1}\left(\frac{Y}{X}\right) \\
\alpha=\operatorname{sen}^{-1}\left(\frac{2,62}{4,2}\right) \\
\alpha=38,59^{\circ}
\end{gathered}
$$

Este valor de ângulo de abertura da cadeia de isoladores, $\alpha=38,59^{\circ}$, é ainda maior que os valores típicos utilizados em Furnas, que variam de 20 a $36^{\circ}$, dependendo dos projetos originais de cada LT. Os valores dos ângulos de abertura da cadeia de isoladores são os mesmos para as fases externas, independente do sentido de abertura. Ressalta-se que para a fase central da LT, deva ser montada uma cadeia dupla de isoladores onde não há balanço da 
cadeia ou formação de ângulos de abertura, o que evitará diminuição da distância original da fase central para a estrutura.

\section{ANEXO D}

\section{Resultados das Análises de Curto-Circuito}


Neste anexo são apresentados os resultados dos cálculos de curto-circuito trifásico e fase-terra utilizados para subsidiar as análises apresentadas no Capítulo 4. Todos os resultados são mostrados nas tabelas que seguem.

Tabela D-1 - Falta trifásica em Furnas

\begin{tabular}{|c|c|c|c|c|c|c|c|c|}
\hline \multirow{2}{*}{ Casos } & \multicolumn{4}{|c|}{ Furnas } & \multicolumn{4}{c|}{ Poços de Caldas } \\
\cline { 2 - 9 } & Icc (kA) & $\mathbf{U A}(\mathbf{k V})$ & $\mathbf{U B}(\mathbf{k V})$ & $\mathbf{U C}(\mathbf{k V})$ & $\mathbf{I c c}(\mathbf{k A})$ & $\mathbf{U A}(\mathbf{k V})$ & $\mathbf{U B}(\mathbf{k V})$ & $\mathbf{U C}(\mathbf{k V})$ \\
\hline $\mathbf{1}$ & 24,52 & 0 & 0 & 0 & 3,18 & 166,38 & 166,38 & 166,38 \\
\hline $\mathbf{2}$ & 24,88 & 0 & 0 & 0 & 3,54 & 162,74 & 162,74 & 162,74 \\
\hline $\mathbf{3}$ & 25,09 & 0 & 0 & 0 & 3,75 & 160,54 & 160,54 & 160,54 \\
\hline $\mathbf{4}$ & 24,89 & 0 & 0 & 0 & 3,55 & 162,65 & 162,65 & 162,65 \\
\hline $\mathbf{5}$ & 18,14 & 0 & 0 & 0 & 3,41 & 178,41 & 178,41 & 178,41 \\
\hline $\mathbf{6}$ & 18,41 & 0 & 0 & 0 & 3,69 & 169,59 & 169,59 & 169,59 \\
\hline $\mathbf{7}$ & 18,61 & 0 & 0 & 0 & 3,88 & 163,22 & 163,22 & 163,22 \\
\hline $\mathbf{8}$ & 18,42 & 0 & 0 & 0 & 3,70 & 169,34 & 169,34 & 169,34 \\
\hline
\end{tabular}

Tabela D-2 - Falta trifásica em Furnas com resistência de falta

\begin{tabular}{|c|c|c|c|c|c|c|c|c|}
\hline \multirow{2}{*}{ Casos } & \multicolumn{4}{|c|}{ Furnas } & \multicolumn{4}{c|}{ Poços de Caldas } \\
\cline { 2 - 10 } & $\mathbf{I c c}(\mathbf{k A})$ & $\mathbf{U A}(\mathbf{k V})$ & $\mathbf{U B}(\mathbf{k V})$ & $\mathbf{U C}(\mathbf{k V})$ & $\mathbf{I c c}(\mathbf{k A})$ & $\mathbf{U A}(\mathbf{k V})$ & $\mathbf{U B}(\mathbf{k V})$ & $\mathbf{U C}(\mathbf{k V})$ \\
\hline $\mathbf{1}$ & 5,46 & 191,35 & 191,35 & 191,35 & 0,71 & 197,31 & 197,31 & 197,31 \\
\hline $\mathbf{2}$ & 5,47 & 191,61 & 191,61 & 191,61 & 0,78 & 197,03 & 197,03 & 197,03 \\
\hline $\mathbf{3}$ & 5,47 & 191,60 & 191,60 & 191,60 & 0,82 & 197,07 & 197,07 & 197,07 \\
\hline $\mathbf{4}$ & 5,47 & 191,67 & 191,67 & 191,67 & 0,78 & 196,97 & 196,97 & 196,97 \\
\hline $\mathbf{5}$ & 7,33 & 256,75 & 256,75 & 256,75 & 1,38 & 272,12 & 272,12 & 272,12 \\
\hline $\mathbf{6}$ & 7,36 & 257,70 & 257,70 & 257,70 & 1,47 & 270,92 & 270,92 & 270,92 \\
\hline $\mathbf{7}$ & 7,38 & 258,34 & 258,34 & 258,34 & 1,54 & 270,19 & 270,19 & 270,19 \\
\hline $\mathbf{8}$ & 7,36 & 257,83 & 257,83 & 257,83 & 1,47 & 270,67 & 270,67 & 270,67 \\
\hline
\end{tabular}


Tabela D-3 - Falta monofásica em Furnas

\begin{tabular}{|c|c|c|c|c|c|c|c|c|}
\hline \multirow{2}{*}{ Casos } & \multicolumn{4}{|c|}{ Furnas } & \multicolumn{5}{c|}{ Poços de Caldas } \\
\cline { 2 - 9 } & Icc (kA) & UA (kV) & $\mathbf{U B}(\mathbf{k V})$ & $\mathbf{U C}(\mathbf{k V})$ & Icc $(\mathbf{k A})$ & $\mathbf{U A}(\mathbf{k V})$ & $\mathbf{U B}(\mathbf{k V})$ & $\mathbf{U C}(\mathbf{k V})$ \\
\hline $\mathbf{1}$ & 23,42 & 0 & 203,15 & 204,38 & 2,35 & 171,53 & 197,88 & 197,08 \\
\hline $\mathbf{2}$ & 23,63 & 0 & 203,51 & 204,94 & 2,57 & 169,08 & 197,64 & 196,56 \\
\hline $\mathbf{3}$ & 23,76 & 0 & 203,97 & 205,10 & 2,71 & 167,65 & 197,26 & 196,42 \\
\hline $\mathbf{4}$ & 23,65 & 0 & 203,32 & 205,02 & 2,61 & 175,09 & 194,06 & 194,36 \\
\hline $\mathbf{5}$ & 17,06 & 0 & 296,34 & 298,69 & 2,54 & 190,79 & 287,88 & 284,30 \\
\hline $\mathbf{6}$ & 17,22 & 0 & 296,85 & 299,61 & 2,71 & 184,67 & 287,50 & 283,23 \\
\hline $\mathbf{7}$ & 17,34 & 0 & 297,26 & 300,24 & 2,83 & 180,33 & 287,18 & 282,49 \\
\hline $\mathbf{8}$ & 17,23 & 0 & 296,78 & 299,71 & 2,72 & 184,47 & 287,61 & 283,11 \\
\hline
\end{tabular}

Tabela D-4 - Falta monofásica em Furnas com resistência de falta

\begin{tabular}{|c|c|c|c|c|c|c|c|c|}
\hline \multirow{2}{*}{ Casos } & \multicolumn{5}{|c|}{ Furnas } & \multicolumn{5}{c|}{ Poços de Caldas } \\
\cline { 2 - 9 } & Icc (kA) & $\mathbf{U A}(\mathbf{k V})$ & $\mathbf{U B}(\mathbf{k V})$ & $\mathbf{U C}(\mathbf{k V})$ & Icc $(\mathbf{k A})$ & $\mathbf{U A ~ ( k V )}$ & $\mathbf{U B}(\mathbf{k V})$ & $\mathbf{U C}(\mathbf{k V})$ \\
\hline $\mathbf{1}$ & 5,44 & 190,55 & 201,29 & 198,06 & 0,55 & 197,80 & 197,01 & 200,61 \\
\hline $\mathbf{2}$ & 5,45 & 190,73 & 201,51 & 197,93 & 0,60 & 197,43 & 198,09 & 199,61 \\
\hline $\mathbf{3}$ & 5,45 & 190,73 & 201,62 & 197,84 & 0,62 & 197,45 & 197,98 & 199,70 \\
\hline $\mathbf{4}$ & 5,45 & 190,76 & 201,50 & 197,97 & 0,60 & 197,56 & 196,75 & 200,72 \\
\hline $\mathbf{5}$ & 7,23 & 253,22 & 296,07 & 285,82 & 1,07 & 273,28 & 286,11 & 288,65 \\
\hline $\mathbf{6}$ & 7,25 & 253,73 & 296,62 & 285,65 & 1,14 & 272,36 & 285,42 & 288,81 \\
\hline $\mathbf{7}$ & 7,26 & 254,16 & 297,01 & 285,52 & 1,18 & 271,79 & 284,92 & 288,95 \\
\hline $\mathbf{8}$ & 7,25 & 253,82 & 296,63 & 285,68 & 1,14 & 272,17 & 285,41 & 288,77 \\
\hline
\end{tabular}

Tabela D-5 - Falta trifásica em Poços de Caldas

\begin{tabular}{|c|c|c|c|c|c|c|c|c|}
\hline \multirow{2}{*}{ Casos } & \multicolumn{4}{|c|}{ Furnas } & \multicolumn{5}{c|}{ Poços de Caldas } \\
\cline { 2 - 10 } & Icc $(\mathbf{k A})$ & $\mathbf{U A}(\mathbf{k V})$ & $\mathbf{U B}(\mathbf{k V})$ & $\mathbf{U C}(\mathbf{k V})$ & $\mathbf{I c c}(\mathbf{k A})$ & $\mathbf{U A}(\mathbf{k V})$ & $\mathbf{U B}(\mathbf{k V})$ & $\mathbf{U C}(\mathbf{k V})$ \\
\hline $\mathbf{1}$ & 3,23 & 168,97 & 168,97 & 168,97 & 22,60 & 0 & 0 & 0 \\
\hline $\mathbf{2}$ & 3,60 & 165,55 & 165,55 & 165,55 & 22,96 & 0 & 0 & 0 \\
\hline $\mathbf{3}$ & 3,82 & 163,48 & 163,48 & 163,48 & 23,19 & 0 & 0 & 0 \\
\hline $\mathbf{4}$ & 3,61 & 165,45 & 165,45 & 165,45 & 22,98 & 0 & 0 & 0 \\
\hline $\mathbf{5}$ & 4,02 & 209,85 & 209,85 & 209,85 & 12,96 & 0 & 0 & 0 \\
\hline $\mathbf{6}$ & 4,40 & 202,33 & 202,33 & 202,33 & 13,35 & 0 & 0 & 0 \\
\hline $\mathbf{7}$ & 4,68 & 196,77 & 196,77 & 196,77 & 13,63 & 0 & 0 & 0 \\
\hline $\mathbf{8}$ & 4,41 & 202,12 & 202,12 & 202,12 & 13,36 & 0 & 0 & 0 \\
\hline
\end{tabular}


Tabela D-6 - Falta trifásica em Poços de Caldas com resistência de falta

\begin{tabular}{|c|c|c|c|c|c|c|c|c|}
\hline \multirow{2}{*}{ Casos } & \multicolumn{4}{|c|}{ Furnas } & \multicolumn{4}{c|}{ Poços de Caldas } \\
\cline { 2 - 9 } & Icc (kA) & $\mathbf{U A}(\mathbf{k V})$ & $\mathbf{U B}(\mathbf{k V})$ & $\mathbf{U C}(\mathbf{k V})$ & $\mathbf{I c c}(\mathbf{k A})$ & $\mathbf{U A}(\mathbf{k V})$ & $\mathbf{U B}(\mathbf{k V})$ & $\mathbf{U C}(\mathbf{k V})$ \\
\hline $\mathbf{1}$ & 0,77 & 197,20 & 197,20 & 197,20 & 5,41 & 189,58 & 189,58 & 189,58 \\
\hline $\mathbf{2}$ & 0,85 & 196,93 & 196,93 & 196,93 & 5,42 & 189,93 & 189,93 & 189,93 \\
\hline $\mathbf{3}$ & 0,89 & 196,96 & 196,96 & 196,96 & 5,42 & 189,95 & 189,95 & 189,95 \\
\hline $\mathbf{4}$ & 0,87 & 197,04 & 196,87 & 196,87 & 5,43 & 190,03 & 190,03 & 190,03 \\
\hline $\mathbf{5}$ & 2,10 & 268,09 & 268,09 & 268,09 & 6,77 & 237,11 & 237,11 & 237,11 \\
\hline $\mathbf{6}$ & 2,25 & 266,72 & 266,72 & 266,72 & 6,84 & 239,63 & 239,63 & 239,63 \\
\hline $\mathbf{7}$ & 2,37 & 265,87 & 265,87 & 265,87 & 6,89 & 241,34 & 241,34 & 241,34 \\
\hline $\mathbf{8}$ & 2,26 & 266,46 & 266,46 & 266,46 & 6,85 & 239,93 & 239,93 & 239,93 \\
\hline
\end{tabular}

Tabela D-7 - Falta monofásica em Poços de Caldas

\begin{tabular}{|c|c|c|c|c|c|c|c|c|}
\hline \multirow{2}{*}{ Casos } & \multicolumn{4}{|c|}{ Furnas } & \multicolumn{5}{c|}{ Poços de Caldas } \\
\cline { 2 - 9 } & $\mathbf{I c c}(\mathbf{k A})$ & $\mathbf{U A}(\mathbf{k V})$ & $\mathbf{U B}(\mathbf{k V})$ & $\mathbf{U C}(\mathbf{k V})$ & $\mathbf{I c c}(\mathbf{k A})$ & $\mathbf{U A}(\mathbf{k V})$ & $\mathbf{U B}(\mathbf{k V})$ & $\mathbf{U C}(\mathbf{k V})$ \\
\hline $\mathbf{1}$ & 2,07 & 179,69 & 198,11 & 197,77 & 16,55 & 0 & 227,16 & 233,78 \\
\hline $\mathbf{2}$ & 2,26 & 177,95 & 197,90 & 197,42 & 16,71 & 0 & 227,68 & 234,55 \\
\hline $\mathbf{3}$ & 2,37 & 176,96 & 197,61 & 197,33 & 16,79 & 0 & 228,23 & 234,83 \\
\hline $\mathbf{4}$ & 2,29 & 179,59 & 198,01 & 197,50 & 16,73 & 0 & 227,73 & 234,72 \\
\hline $\mathbf{5}$ & 2,56 & 238,07 & 288,06 & 286,45 & 8,83 & 0 & 339,18 & 348,71 \\
\hline $\mathbf{6}$ & 2,74 & 234,51 & 287,81 & 285,89 & 8,98 & 0 & 340,46 & 350,63 \\
\hline $\mathbf{7}$ & 2,87 & 231,96 & 287,60 & 285,50 & 9,09 & 0 & 341,48 & 352,02 \\
\hline $\mathbf{8}$ & 2,75 & 234,38 & 287,87 & 285,83 & 8,99 & 0 & 340,35 & 350,80 \\
\hline
\end{tabular}

Tabela D-8 - Falta monofásica em Poços de Caldas com resistência de falta

\begin{tabular}{|c|c|c|c|c|c|c|c|c|}
\hline \multirow{2}{*}{ Casos } & \multicolumn{4}{|c|}{ Furnas } & \multicolumn{4}{c|}{ Poços de Caldas } \\
\cline { 2 - 9 } & Icc (kA) & $\mathbf{U A ~ ( k V )}$ & $\mathbf{U B}(\mathbf{k V})$ & $\mathbf{U C}(\mathbf{k V})$ & Icc (kA) & $\mathbf{U A ~ ( k V )}$ & $\mathbf{U B}(\mathbf{k V )})$ & $\mathbf{U C}(\mathbf{k V})$ \\
\hline $\mathbf{1}$ & 0,54 & 198,02 & 197,04 & 200,68 & 5,20 & 182,18 & 216,07 & 191,33 \\
\hline $\mathbf{2}$ & 0.70 & 196,97 & 198,11 & 199,54 & 5,21 & 182,44 & 216,27 & 191,25 \\
\hline $\mathbf{3}$ & 0,73 & 196,97 & 198,01 & 199,61 & 5,21 & 182,46 & 216,38 & 191,17 \\
\hline $\mathbf{4}$ & 0,71 & 197,10 & 198,18 & 199,51 & 5,21 & 182,52 & 216,31 & 191,25 \\
\hline $\mathbf{5}$ & 1,67 & 268,13 & 286,81 & 288,22 & 5,75 & 201,39 & 345,96 & 285,20 \\
\hline $\mathbf{6}$ & 1,77 & 266,92 & 286,29 & 288,23 & 5,80 & 203,10 & 347,08 & 285,01 \\
\hline $\mathbf{7}$ & 1,84 & 266,12 & 285,91 & 288,25 & 5,83 & 204,24 & 347,90 & 284,85 \\
\hline $\mathbf{8}$ & 1,77 & 266,75 & 286,29 & 288,19 & 5,80 & 203,27 & 347,12 & 285,07 \\
\hline
\end{tabular}


Tabela D-9 - Falta Trifásica em 50\% da LT

\begin{tabular}{|c|c|c|c|c|c|c|c|c|c|c|}
\hline \multirow{2}{*}{ Casos } & \multicolumn{4}{|c|}{ Furnas } & \multicolumn{4}{c|}{ Poços de Caldas } & \multicolumn{2}{c|}{ Meio da LT } \\
\cline { 2 - 11 } & $\begin{array}{c}\mathbf{I c c} \\
(\mathbf{k A})\end{array}$ & $\begin{array}{c}\text { UA } \\
(\mathbf{k V})\end{array}$ & $\begin{array}{c}\mathbf{U B} \\
(\mathbf{k V})\end{array}$ & $\begin{array}{c}\mathbf{U C} \\
(\mathbf{k V})\end{array}$ & $\begin{array}{c}\mathbf{I c c} \\
(\mathbf{k A})\end{array}$ & $\begin{array}{c}\mathbf{U A} \\
(\mathbf{k V})\end{array}$ & $\begin{array}{c}\mathbf{U B} \\
(\mathbf{k V})\end{array}$ & $\begin{array}{c}\text { UC } \\
(\mathbf{k V})\end{array}$ & $\begin{array}{c}\text { Icc } \\
(\mathbf{k A})\end{array}$ & $\begin{array}{c}\text { Sk } \\
(\mathbf{M V A})\end{array}$ \\
\hline $\mathbf{1}$ & 5,62 & 146,71 & 146,71 & 146,71 & 5,47 & 142,86 & 142,86 & 142,86 & 11,10 & 6632,85 \\
\hline $\mathbf{2}$ & 6,16 & 141,63 & 141,63 & 141,63 & 5,98 & 137,58 & 137,58 & 137,58 & 12,15 & 7263,38 \\
\hline $\mathbf{3}$ & 6,49 & 138,63 & 138,63 & 138,63 & 6,29 & 134,45 & 134,45 & 134,45 & 12,78 & 7638,68 \\
\hline $\mathbf{4}$ & 6,18 & 141,49 & 141,49 & 141,49 & 6,00 & 137,43 & 137,43 & 137,43 & 12,18 & 7281,02 \\
\hline $\mathbf{5}$ & 6,31 & 164,83 & 164,83 & 164,83 & 4,94 & 129,09 & 129,09 & 129,09 & 11,26 & 9757,24 \\
\hline $\mathbf{6}$ & 6,78 & 155,75 & 155,75 & 155,75 & 5,22 & 120,06 & 120,06 & 120,06 & 12,00 & 10398,20 \\
\hline $\mathbf{7}$ & 7,11 & 149,25 & 149,25 & 149,25 & 5,42 & 113,77 & 113,77 & 113,77 & 12,53 & 10853,60 \\
\hline $\mathbf{8}$ & 6,79 & 155,50 & 155,50 & 155,50 & 5,23 & 119,81 & 119,81 & 119,81 & 12,02 & 10415,50 \\
\hline
\end{tabular}

Tabela D-10 - Falta trifásica em $50 \%$ da LT, com resistência de falta

\begin{tabular}{|c|c|c|c|c|c|c|c|c|c|c|}
\hline \multirow{2}{*}{ Casos } & \multicolumn{4}{|c|}{ Furnas } & \multicolumn{4}{c|}{ Poços de Caldas } & \multicolumn{2}{c|}{ Meio da LT } \\
\cline { 2 - 11 } & $\begin{array}{c}\text { Icc } \\
(\mathbf{k A})\end{array}$ & $\begin{array}{c}\text { UA } \\
(\mathbf{k V})\end{array}$ & $\begin{array}{c}\text { UB } \\
(\mathbf{k V})\end{array}$ & $\begin{array}{c}\text { UC } \\
(\mathbf{k V})\end{array}$ & $\begin{array}{c}\text { Icc } \\
(\mathbf{k A})\end{array}$ & $\begin{array}{c}\text { UA } \\
(\mathbf{k V})\end{array}$ & $\begin{array}{c}\text { UB } \\
(\mathbf{k V})\end{array}$ & $\begin{array}{c}\text { UC } \\
(\mathbf{k V})\end{array}$ & $\begin{array}{c}\text { Icc } \\
(\mathbf{k A})\end{array}$ & $\begin{array}{c}\text { Scc } \\
(\mathbf{M V A})\end{array}$ \\
\hline $\mathbf{1}$ & 2,48 & 188,80 & 188,80 & 188,80 & 2,41 & 187,81 & 187,81 & 187,81 & 4,9 & 2925,53 \\
\hline $\mathbf{2}$ & 2,54 & 189,21 & 189,21 & 189,21 & 2,47 & 188,29 & 188,29 & 188,29 & 5,02 & 3000,19 \\
\hline $\mathbf{3}$ & 2,56 & 189,63 & 189,63 & 189,63 & 2,48 & 188,75 & 188,75 & 188,75 & 5,04 & 3013,18 \\
\hline $\mathbf{4}$ & 2,55 & 189,17 & 189,17 & 189,17 & 2,48 & 188,25 & 188,25 & 188,25 & 5,04 & 3009,49 \\
\hline $\mathbf{5}$ & 3,6 & 251,49 & 251,49 & 251,49 & 2,82 & 243,55 & 243,55 & 243,55 & 6,43 & 5569,11 \\
\hline $\mathbf{6}$ & 3,73 & 252,00 & 252,00 & 252,00 & 2,87 & 245,17 & 245,17 & 245,17 & 6,61 & 5722,57 \\
\hline $\mathbf{7}$ & 3,81 & 252,51 & 252,51 & 252,51 & 2,90 & 246,44 & 246,44 & 246,44 & 6,72 & 5817,24 \\
\hline $\mathbf{8}$ & 3,74 & 251,81 & 251,81 & 251,81 & 2,88 & 245,08 & 245,08 & 245,08 & 6,63 & 5738,33 \\
\hline
\end{tabular}

Tabela D-11 - Falta monofásica em 50\% da LT

\begin{tabular}{|c|c|c|c|c|c|c|c|c|c|c|}
\hline \multirow{2}{*}{ Casos } & \multicolumn{4}{|c|}{ Furnas } & \multicolumn{4}{c|}{ Poços de Caldas } & \multicolumn{2}{c|}{ Meio da LT } \\
\cline { 2 - 11 } & $\begin{array}{c}\text { Icc } \\
(\mathbf{k A})\end{array}$ & $\begin{array}{c}\text { UA } \\
(\mathbf{k V})\end{array}$ & $\begin{array}{c}\text { UB } \\
(\mathbf{k V})\end{array}$ & $\begin{array}{c}\text { UC } \\
(\mathbf{k V})\end{array}$ & $\begin{array}{c}\text { Icc } \\
(\mathbf{k A})\end{array}$ & $\begin{array}{c}\text { UA } \\
(\mathbf{k V})\end{array}$ & $\begin{array}{c}\text { UB } \\
(\mathbf{k V})\end{array}$ & $\begin{array}{c}\text { UC } \\
(\mathbf{k V})\end{array}$ & $\begin{array}{c}\text { Icc } \\
(\mathbf{k A})\end{array}$ & $\begin{array}{c}\text { Scc } \\
(\mathbf{M V A})\end{array}$ \\
\hline $\mathbf{1}$ & 3,36 & 167,72 & 199,41 & 199,77 & 3,21 & 155,94 & 204,6 & 204,34 & 6,55 & 1304,24 \\
\hline $\mathbf{2}$ & 3,54 & 165,94 & 199,41 & 199,84 & 3,38 & 153,61 & 204,88 & 204,64 & 6,91 & 1375,60 \\
\hline $\mathbf{3}$ & 3,64 & 165,06 & 199,40 & 199,84 & 3,47 & 152,44 & 205,18 & 204,71 & 7,09 & 1413,47 \\
\hline $\mathbf{4}$ & 3,63 & 165,08 & 198,75 & 199,62 & 3,66 & 170,93 & 193,87 & 196,26 & 7,28 & 1450,34 \\
\hline $\mathbf{5}$ & 4,13 & 207,28 & 285,93 & 290,13 & 3,12 & 150,23 & 309,10 & 308,33 & 7,22 & 2084,71 \\
\hline $\mathbf{6}$ & 4,33 & 203,35 & 289,94 & 290,18 & 3,23 & 145,33 & 309,89 & 309,32 & 7,52 & 2171,63 \\
\hline $\mathbf{7}$ & 4,46 & 200,66 & 289,95 & 290,22 & 3,30 & 142,07 & 310,49 & 309,97 & 7,72 & 2230,71 \\
\hline $\mathbf{8}$ & 4,33 & 203,18 & 289,95 & 290,20 & 3,23 & 145,13 & 309,82 & 309,43 & 7,53 & 2174,51 \\
\hline
\end{tabular}


Tabela D-12 - Falta monofásica em 50\% da LT, com resistência de falta

\begin{tabular}{|c|c|c|c|c|c|c|c|c|c|c|}
\hline \multirow{2}{*}{ Casos } & \multicolumn{4}{|c|}{ Furnas } & \multicolumn{4}{c|}{ Poços de Caldas } & \multicolumn{2}{c|}{ Meio da LT } \\
\cline { 2 - 11 } & $\begin{array}{c}\text { Icc } \\
(\mathbf{k A})\end{array}$ & $\begin{array}{c}\text { UA } \\
(\mathbf{k V})\end{array}$ & $\begin{array}{c}\mathbf{U B} \\
(\mathbf{k V})\end{array}$ & $\begin{array}{c}\text { UC } \\
(\mathbf{k V})\end{array}$ & $\begin{array}{c}\text { Icc } \\
(\mathbf{k A})\end{array}$ & $\begin{array}{c}\text { UA } \\
(\mathbf{k V})\end{array}$ & $\begin{array}{c}\text { UB } \\
(\mathbf{k V})\end{array}$ & $\begin{array}{c}\text { UC } \\
(\mathbf{k V})\end{array}$ & $\begin{array}{c}\text { Icc } \\
(\mathbf{k A})\end{array}$ & $\begin{array}{c}\text { Scc } \\
(\mathbf{M V A})\end{array}$ \\
\hline $\mathbf{1}$ & 2,00 & 187,45 & 199,44 & 198,93 & 1,93 & 182,56 & 205,29 & 198,1 & 3,95 & 786,02 \\
\hline $\mathbf{2}$ & 2,07 & 187,49 & 199,43 & 198,89 & 1,98 & 182,64 & 205,5 & 197,97 & 4,04 & 805,44 \\
\hline $\mathbf{3}$ & 2,09 & 187,67 & 199,42 & 198,86 & 1,99 & 182,91 & 205,58 & 197,89 & 4,07 & 810,71 \\
\hline $\mathbf{4}$ & 2,06 & 187,84 & 198,90 & 199,15 & 2,08 & 189,30 & 194,55 & 201,58 & 4,13 & 823,03 \\
\hline $\mathbf{5}$ & 2,89 & 249,92 & 290,04 & 288,05 & 2,18 & 225,01 & 313,22 & 287,08 & 5,05 & 1458,2 \\
\hline $\mathbf{6}$ & 2,97 & 249,54 & 290,01 & 287,98 & 2,22 & 225,41 & 314,02 & 286,73 & 5,17 & 1493,67 \\
\hline $\mathbf{7}$ & 3,03 & 249,39 & 289,98 & 287,93 & 2,24 & 225,83 & 314,55 & 286,48 & 5,25 & 1515,09 \\
\hline $\mathbf{8}$ & 2,98 & 249,39 & 290,01 & 287,98 & 2,22 & 225,28 & 314,06 & 286,75 & 5,18 & 1496,69 \\
\hline
\end{tabular}


ANEXO E

\section{Publicações}


O trabalho de pesquisa resultante desta dissertação de Mestrado originou as seguintes publicações científicas:

- AlMEIDA, V. F. ; VIEIRA JUNIOR, J. C. M. . Metodologia para Avaliar o Impacto de Técnicas de Repotenciação no Desempenho de Linhas de Transmissão de Energia Elétrica. In: IEEE PES Transmission and Distribution Conference and Exposition Latin America, 2010, São Paulo. Proceedings of the IEEE PES Transmission and Distribution Conference and Exposition Latin America, 2010.

- ALMEIDA, V. F. ; SILVA JUNIOR, E. M. ; VIEIRA JUNIOR, J. C. M. . Índices de Desempenho para Análise de Técnicas de Repotenciação de Linhas de Transmissão de Energia Elétrica. In: IV Simpósio Brasileiro de Sistemas Elétricos, 2012, Goiânia. Anais do IV SBSE, 2012. 